UNIVERSIDADE DE BRASÍLIA - UnB INSTITUTO DE CIÊNCIAS SOCIAIS-ICS CENTRO DE PESQUISA E PÓS-GRADUAÇÃO SOBRE AS AMÉRICAS- CEPPAC, PROGRAMA DE MESTRADO

\title{
"A ADMINISTRAÇÃO E GESTÃO PÚBLICA DOS TERRITÓRIOS INDÍGENAS DO MUNICÍPIO DE TORIBÍO, NORTE DO CAUCA, COLÔMBIA".
}

NELSON ANDRES HERNANDEZ QUICENO

Brasília (DF), Julho 7 de 2015. 


\title{
UNIVERSIDADE DE BRASÍLIA-UnB INSTITUTO DE \\ CIÊNCIAS SOCIAIS-ICSCENTRO DE PESQUISA E PÓS- GRADUAÇÃO SOBRE AS AMÉRICAS- CEPPAC, PROGRAMA DE \\ MESTRADO
}

\author{
"A ADMINISTRAÇÃO E GESTÃo PÚBLICA DOS TERRITÓRIOS \\ INDÍGENAS DO MUNICÍPIO DE TORIBÍO, NORTE DO CAUCA, \\ COLÔMBIA".
}

NELSON ANDRES HERNANDEZ QUICENO

Orientador: Dr. STEPHEN GRANT BAINES

Dissertação apresentada como requisito parcial para conclusão do Mestrado em Ciências Sociais da Universidade de Brasília.

Brasília (DF), Julho 7 de 2015. 


\title{
"A ADMINISTRAÇÃO E GESTÃO PÚBLICA DOS TERRITÓRIOS INDÍGENAS DO MUNICÍPIO DE TORIBÍO, NORTE DO CAUCA, COLÔMBIA".
}

\author{
NELSON ANDRES HERNANDEZ QUICENO
}

\begin{abstract}
Dissertação submetida ao corpo docente do Programa de Pós-Graduação em Mestrado em Ciências Sociais da Universidade de Brasília (UnB) como parte dos requisitos necessários à obtenção do grau de mestre.
\end{abstract}

Banca Examinadora:

Prof. STEPHEN GRANT BAINeS - Presidente - DAN/UnB Prof. Cristhian Teófilo da Silva - CEPPAC Prof. Edmundo Pereira-MN/UFRJ 


\section{Brasília (DF), Julho 7 de 2015.}

H557a Hernandez Quiceno, Nelson Andrés.

A administração e gestão pública dos territórios indígenas do município de Toribío, norte do Cauca, Colômbia / Nelson Andrés Hernandez Quiceno. - 2015.

169 p. ; $30 \mathrm{~cm}$.

Dissertação (mestrado)—Universidade de Brasília, Instituto de Ciências Sociais, Programa de Pós-Graduação em Estudos Comparados sobre as Américas, Mestrado em Ciências Sociais, 2015.

Inclui bibliografia.

Orientação: Stephen Grant Baines.

1. Índios da Colômbia - Usos e costumes. 2. Comunidade indígena - Colômbia. 3. Administração pública local Descentralização - Toribío (Colômbia). 4. Toribío (Colômbia) Relações étnicas. I. Baines, Stephen Grant. II. Título.

CDU 39:32(816=082) 
A mi familia por su apoyo incondicional, en memoria de mi abuela María Virgelina Cano. 


\section{AGRADECIMIENTOS}

Quero começar por agradecer a minha família pelo apoio incondicional, desde que eu tinha pensado na hipótese de abandonar a Colômbia para fazer no exterior uma Pós-graduação, seu entusiasmo e apoio para não desistir de tal. Comunidade nasa ao município de Toribío em geral que eu hospedei agradável calorosamente no seu território, partilha, imersão e pé no chão na construção de um país de pessoas sem proprietários.

Especialmente para as pessoas que gentilmente concordaram em dar-me uma entrevista, dême informações e me convidar ou permitir-me participar em reuniões, assembleias, mingas e mobilizações. Da mesma forma, quero agradecer o Professor do programa de etno-educação CECIDIC Jaime Vitonas, que gentilmente eu vou ficar em casa e fiz minha estadia no município de Toribío muito agradável durante o trabalho de campo desta dissertação. Em Brasília, graças ao corpo docente do centro de Pós-graduação em que estudos comparados sobre como as Américas UnB (PPG/CEPPAC).

Especialmente a meu orientador de dissertação Grant Stephen Baines, pelo seu rigorosas leituras e comentários de sucesso que contribuíram decisivamente para as reflexões realizadas ao longo desta dissertação. Professor Cristhian Teófilo da Silva que, desde que entre o contato com ele, tornou-se um importante parceiro, consultor e amigo, que salientou que levou a decisão de realizar o mestre do programa CEPPAC-UnB.

Não posso deixar de mencionar nestes agradecimentos ao Professor Edmundo Pereira, que esteve sempre disposto a compartilhar e incentivar a reflexão sobre temas de investigação comum em torno da administração e gestão pública dos territórios indígenas em Colômbia. Também gostaria de agradecer o corpo administrativo do CEPPAC, Jacinta Fontenele por sua cordialidade e diligência. Meus colegas de mestrado e doutorado que solidariamente deu-me sua ajuda desde que toca e obrigado a todos aqueles que conseguiram superar muitos obstáculos. Entre eles, Elizabeth Ruano quem colocou os espíritos da natureza em mim andando para me mostrar o caminho das pedras e Márcia Guedes Vieira, com quem vai ficar eternamente grato por sua solidariedade.

Quero agradecer calorosamente Jose Manuel Cruz e M. Jehyra Asencio mentiras que estavam sempre dispostos a me ajudar a colocar meu serviço sua política sobrenatural". E como não mencionar estes agradecimentos aos meus colegas "anarquista República 102", com aqueles 
que alcançar tecendo relações reais de irmandade e fraternidade da rotina da vida diária, que é fácil para nós. José Cardozo Filho quem me contágio da alegria simples e lembrou-me do prazer de ir, porque como mestre Galeano disse-nos quando nós tivemos a sorte de escutá-lo, você não está viajando para chegar, você viaja por go. Fabio boa de pessoas com quem tive a sorte de compartilhar momentos agradáveis em torno da palavra, música e alegria nordestina que representa.

Por último mas não menos importante, para o minga coletivo de pensamento com quem compartilhar a busca de novas estratégias metodológicas alternativas articular nós mesmos como investigadores aos processos organizacionais das comunidades.

Mas eu gostaria de agradecer-lhe acima de tudo para manter vivo o espírito da produção coletiva de conhecimento em tempo onde a rivalidade e competitividade da lógica de acreditação académica foram extintas práticas de "insurgência epistêmica".

Eu não posso deixar de agradecer explicitamente a professora Patrícia Botero, por seu entusiasmo e apoio incondicional. Mestre Wiliam López que acreditou em mim desde o início e me ajudou a desenvolver o propósito da viagem ao Brasil para fazer estudos de pós-graduação. Todos eles e aqueles que não mencionam devido a menor destas palavras, obrigado. 


\section{RESUMO}

Esta investigação centra-se sobre a gestão e governação do coletivos territórios indígenas na Colômbia, desde a reforma constitucional de 1991, que reconhece uma abordagem multicultural, uma série de direitos territoriais e culturais relacionados com diferenciais com governam territórios indígenas forma autónoma de acordo com os usos e costumes das comunidades que nele habitam. Enfocando o processo de descentralização e participação dos guardas como entidades territoriais indígenas de carácter especial e transição para o sistema de participação SPG do geral, para assegurar a alocação de comunidade de recursos do orçamento nacional para estas instituições com reconhecimento de estado de gestão e administração pública local.

Para alcançar este objetivo, inicialmente, aborda a história do contato interétnico do povo nasa com a sociedade envolvente em diferentes momentos da história do sistema interétnico que configura o cenário em que se desenvolve esta dissertação. Num segundo momento, ele descreve e analisa o esquema tecnocrática de subordinado do estado o exercício de direitos territoriais de diferenciais culturais a nível local, enquadrando-os em um estado de projeto de modernização neoliberal, que tem como sua maior manifestação, o processo de descentralização da administração pública. Aproximando-se para a experiência do povo nasa ao município de Toribío na implementação de sua relação com o sistema geral de participação - SPG, estudo de caso em que os desentendimentos e situações existentes de fricção interétnica são evidentes foi concluída entre uma visão neoliberal de gestão e administração pública da dinâmica do reconhecimento étnico, promovido pelo Estado e a proposta do governo dos processos de autonomia defendida por organizações indígenas.

Palavras-chave: descentralização da administração pública local, usos e costumes, fricções interétnicas, autonomia, comunidade indígena, abrigo, Cabildo. 


\begin{abstract}
This research focuses on public administration and the management of collective indigenous territories in Colombia, from the constitutional reform of 1991, which recognizes, from a multicultural approach, a series of differentiated cultural territorial rights related to governing autonomously indigenous territories according to the uses and customs of the communities that inhabit them. By focusing on the decentralization process and the link of the resguardos as indigenous territorial entities which have a special and transitory character to the Sistema General de Participación-SGP, so as to ensure the allocation of resources from the national budget to these community institutions with State recognition for the management and local public administration.

To achieve this, firstly the history of interethnic contact between the Nasa People and the surrounding society is treated in different moments of the history of interethnic contact, which sets the stage in which this dissertation is developed. In a second moment, the technocratic scheme is described and analyzed which the State subordinates the exercise of differential cultural territorial rights in the local sphere, framing them within a project of neoliberal state modernization, which has as its greatest manifestation the process of territorial decentralization of public administration. The study ends bringing us near to the experience of the Nasa people of Toribío municipality in the operationalization of its connection to the General Participation System (Sistema General de Participación - SGP), in which in this case study the misunderstandings and situations of interethnic friction between a neoliberal vision of management and public administration from the dynamics of ethnic recognition promoted by the state and the proposal of self-government of the processes of autonomy advocated by the indigenous organizations are evident.
\end{abstract}

Keywords: Decentralization, local public administration, uses and customs, situations of interethnic friction, self-government, indigenous community, Resguardo, Cabildo. 


\section{RESUMEN}

Esta investigación se centra en la administración y gestión pública de los territorios colectivos indígenas en Colombia, a partir de las reforma constitucional de 1991 que reconoce desde un enfoque multicultural una serie de derechos territoriales culturales diferenciales relacionados con gobernar de manera autónoma los territorios indígenas de acuerdo a los usos y costumbres de las comunidades que lo habitan. Focalizándonos en el proceso de descentralización y vinculación de los resguardos como entidades territoriales indígenas de carácter especial y transitorio al Sistema General de Participación-SGP, para garantizar la asignación de recursos del presupuesto nacional a estas instituciones comunitaria con reconocimiento Estatal para la gestión y administración pública local.

Para lograr este objetivo, en un primer momento se aborda la historia del contacto interétnico del pueblo nasa con la sociedad envolvente en diferentes momentos de la historia del sistema interétnico que configura el escenario en que se desarrolla esta disertación. En un segundo momento, se describe y analiza el esquema tecnocrático al que supedita el Estado el ejercicio de los derechos culturales diferenciales territoriales en el ámbito local, enmarcándolos en un proyecto de modernización estatal de corte neoliberal, que tiene como mayor manifestación el proceso de descentralización territorial de la administración pública.

Se finaliza aproximándonos a la experiencia del pueblo nasa del municipio de Toribío en la operativización de su vinculación al Sistema General de Participación-SGP, estudio de caso en que son evidentes los desencuentros y situaciones de fricción interétnica existentes entre una visión neoliberal de la gestión y administración pública a partir de las dinámicas de reconocimiento étnico

promovidas por el Estado y la propuesta de gobierno propio de los procesos de autonomía defendidos por las organizaciones indígenas.

Palabras claves: Descentralización, administración pública local, usos y costumbres, fricción interétnica, gobierno propio, comunidad indígena, Resguardo, Cabildo. 


\section{ÍNDICE DE FIGURAS}

Figura 1 Principia-lhes chefias Nasa precolombino de Tierradentro .....................................20

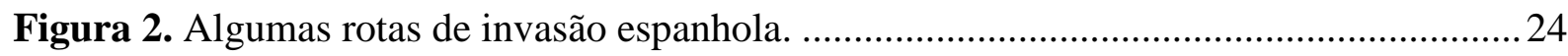

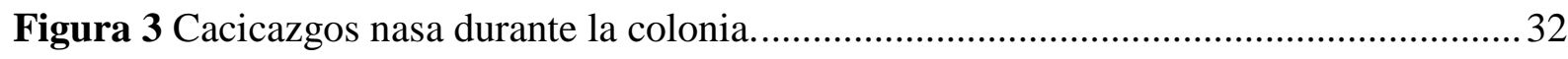

Figura 4. Manuel Quintín Lame. Lame se ve en el centro de esta foto, con el pelo largo y un tabaco en la boca. 1916, Lame es arrestado en la ciudad de Popayán......................................... 49

Figura 5 Primeras reuniones de constitución de una organización indígena en el departamento

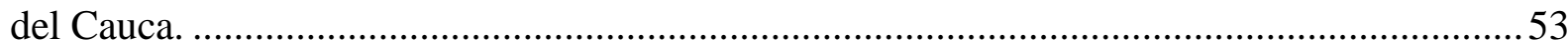

Figura 6 Recuperación de tierras Hacienda Cobaló, Cauca, 1974 ..........................................55

Figura 7 O sentido do desenvolvimento territorial sustentável do departamento nacional de

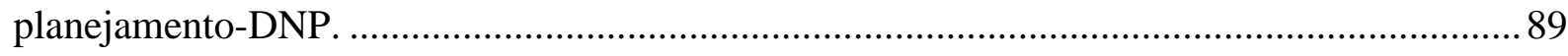

Figura 8 Población colombiana por pertenencia étnica Censo General (DANE, 2005).........90

Figura 9 Distribucion de la poblacion en area rural. (DANE, 2005).....................................91

Ilustración 10 Evolución número de Resguardos reconocidos por el Estado. (DANE-DNP-Conpes

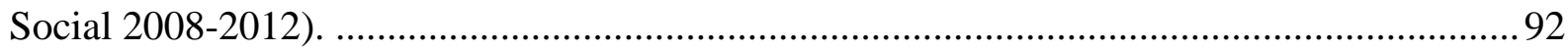

Figura 11 Territorios Indigenas en Colombia.(Contraloría general de la república, 2013 ) ...94

Figura 12 Diagrama de procedimiento para la ejecución y seguimiento de los recursos del SGP para el caso indígena. (Tomado de Duarte 2015, p. 189)....................................................... 100

Figura 13 Fuente: Plan de desarrollo Municipal de Toribío (200-2011)............................... 106

Figura 14 Estructura de la poblacion por edad y sexo, municipio de Toribio 2005 (DANE, 2005).

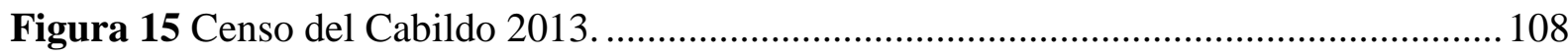

Figura 16 Municipio de Toribío: principales resultados de los Censos de Cabildos. ............ 109

Figura 17 Estructura de poblacion por edad y sexo (Resguardos Indigenas de Toribio 2013.110

Figura 18 Indicadores sociodemográficos de los resguardos del municipio de Toribío-2013

(Censo Cabildo Nasa de Toribio, 2013) ..............................................................................110 
Figura 19 Organigrama de algunas de las dependencias de la administración pública municipal de Toribío. 112

Figura 20 Proyectos financiados segun los programas del proyecto Nasa MATOGI (2013, P.78).

Figura 21 Resguardos beneficiarios de las infraestructuras del Proyecto Nasa: 1980-2010 (MATOGI, 2013, p. 62).

Figura 22 Outros organismos de financiamento dos programas de projeto da Nasa. MATOGI (2013, p. 90). 129

Figura 23 Perfil de projetos de financiamento a entidades: 1980-2010 MATOGI (2013, p. 91). 


\section{SUMÁRIO}

INTRODUÇÃO

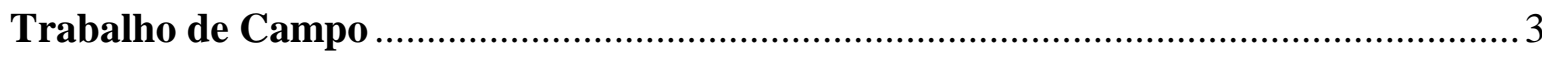

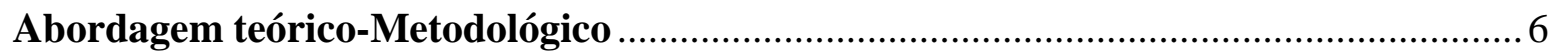

CAPÍTULO 1 - OS FILHOS DA ÁGUA E AS ESTRELAS …….....................................15

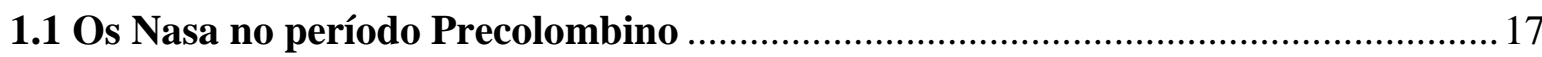

1.2 Os Nasa e o processo de invasão da Europa Ocidental ...........................................21

1.3 Los resguardos y los cacicazgos coloniales …………………………………….......2

1.4. A República e a configuração da nação Estado colombiano......................................38

1.5. A concepção histórica do povo Nasa ………………………………………….......59

CAPÍTULO 2 - DESCENTRALIZAÇÃO ADMINISTRATIVA, ESTADO

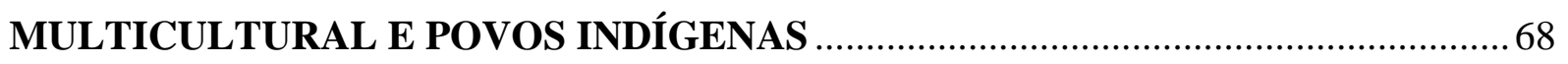

2.1 Processo de descentralização política e administrativa do Estado Colombiano .....69

2.2 Descentralização, Sistema General de Participações e direitos dos povos indígenas78

2.3 Normas e regulamentos do envolvimento dos povos indígenas ao sistema geral de

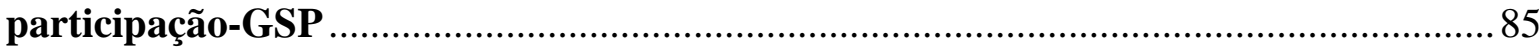

2.4. A governação indígena e o SPG sistema geral participação ……………………...... 88

2.5. Alguns dados estatísticos e demográficos dos povos indígenas na Colômbia.........90

2.6. Limitações estruturais e tecnocráticas da participação dos povos indígenas no SPG

CAPÍTULO 3 - GOVERNO INDÍGENA NO MUNICÍPIO DE TORIBIO, NORTE DEL

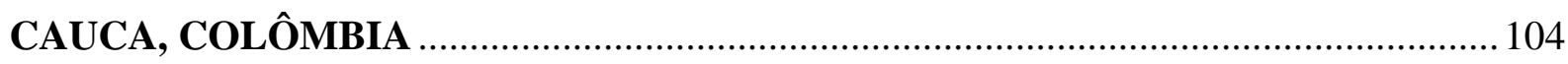

3.1 Contextualização do município de Toribío, Cauca, Colômbia .................................. 105

3.2. Um abordagem demográfica e estatística para o município de Toribío ………..... 106

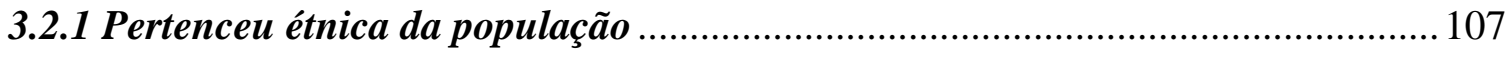


3.3. Organização social e política do município de Toribío

3.3.1. As instituições Estatal municipais

3.3.2 Institucional indígena comunitária

3.3.3. Os resguardos indígenas do município de Toribío

3.3.4. Conselhos dos povos indígenas do município de Toribío

3.3.5 Funções e posições dos conselhos indígenas do município de Toribío

3.4 A formulação e desenvolvimento do plano de vida comunitária dos guardas do município de Toribío

3.4.1 Projeto da Nasa 124

3.4.2. Plano de vida da comunidade nasa 136

3.5 Tulpas ou preceitos constitutivos da administração e gestão pública de M. de Toribío 142

3.5.1. A Tulpa da unidade 144

3.5.2. A Tulpa da cultura 146

3.5.3. O território como Tulpa organizacional 148

3.5.4 Autonomia a tulpa que orienta o projeto significou Politico 149

3.6 Administração e governança local indígena, no município de Toribío 152

3.7 Justaposição institucional e inter-étnico atritos na administração e governação dos territórios indígenas do município de Toribío 155

3.8 Considerações finais 168

REFERÊNCIAS BIBLIOGRÁFICA 170 


\section{INTRODUÇÃO}

Dando-lhe continuidade as revoltas indígenas ocorreu durante todo o período colonial e a República colombiano encenados durante a século XX mobilização visa a recuperação de seus territórios e o reconhecimento e o respeito dos seus povos e cultural de povos indígenas como parte de uma sociedade nacional em que diferentes grupos étnicos são encontrados. (Ver MORALES, 1979;) RAPPAPORT, 1990; FRIEDEMANN; AROCHA, 1982; JIMENO, 1985)

Com elas, sucedeu em 1991 a Constituição estabelece o caráter multiétnico e multicultural da sociedade colombiana, o que significou uma ruptura histórica, porque pela primeira vez uma Constituição reconheceu os povos indígenas como parte integrante da sociedade nacional, na época, que lhes dá uma série de garantias para assegurar sua existência coletivos como sujeitos de direitos. Assim, ele inclui o artigo 7 da Constituição multicultural da Colômbia, "o Estado reconhece e protege a diversidade étnica e cultural da nação colombiana" (Constitución Política de Colômbia 1991). As mudanças ocorridas com a promulgação da constituição de 1991, "são um passo importante para o reconhecimento da identidade e da autonomia indígena" (DOVER; RAPPAPORT, 1996).

As Constituições que precederam contemplam a Colômbia como um país de "um idioma: castelhano, uma única religião: o catolicismo e de uma cultura única: a Colômbia." (PADILLA, 1996, p. 80) Fornece um do principal constitucional altera o artigo 330, que dá a povos indígenas o direito de governar seus territórios de acordo com suas "usa e consuetudinário." " Artigo 330. Em conformidade com a constituição e as leis, os territórios indígenas rege-se pelos conselhos formados e regulados de acordo com os hábitos e costumes de suas comunidades [...]" (Título XI). Da organização TERRITORIAL, nova Constituição política de Colômbia, 1991).

Como expressão de uma nação multi-étnica, a nova Constituição visa dar uma maior autonomia na gestão e administração de seus territórios coletivos, "reconhecer funções de jurisdição no seu território, em conformidade com suas próprias regras e procedimentos, desde que não sejam contrários a constituição e as leis da República"-povos indígenas (artigo 246 da Constituição da Colômbia 1991).

Para a implementação desta lei artigo 329, da Constituição prevê a criação de entidades indígenas territoriais (ETIs) como uma figura política administrativa de caráter especial, que seria a nível de outras entidades territoriais como municípios e departamentos, tendo assim autonomia 
para a gestão dos seus interesses e gestão dos recursos económicos provenientes do orçamento nacional através do seu link para o sistema geral de participação-GSP.

O reconhecimento do carácter multicultural e multiétnico da nação colombiana implica uma reconfiguração do modelo de ordenamento do território e da administração pública, como as novas entidades territoriais devem articular autonomamente para povos indígenas e o estado nacional, deixando para trás as práticas e instituições do projeto novo que o precederam.

O que significa uma mudança importante na relação dos povos indígenas com o estado em gestão e administração pública dos territórios étnicos colectivos. Reconhecer os povos indígenas e afro-descendentes como interlocutores políticos ser sob as figuras de guardas e conselhos comunitários, é lhes concedido o direito de gerenciar e plano de gestão dos territórios vivem autonomamente. Depois de mais de vinte anos de reforma constitucional que declara o multiétnico e multicultural sociedade colombiana caractere, a implementação ou aplicabilidade das diferenças culturais de direitos territoriais e das reformas para o modelo de administração pública que são inerentes a ele, encontrei uma série de dificuldades, tensões e situações de etnias fricção e catalogálas nesta pesquisa partir da conceituação teórica feita pelo antropólogo brasileiro Roberto Cardoso de Oliveira desta noção.

A nível local de territorialidades da etnia surge uma visão de ambiente de desacordo e contradição da administração pública, promovida pelo estado através da dinâmica de corte neoliberal descentralização e autonomia processos administrativos afirmado por organizações indígenas. Com base na experiência da gestão de pessoas da nasa e da administração pública local em territórios indígenas do município de Toribío com a vinculação dos guardas como entidades territoriais indígenas de especiais e de transição para o sistema geral de caráter de participaçãoSPG, abordare nesta dissertação as divergências entre a dinâmica do reconhecimento étnico, promovido pelo estado através de uma visão neoliberal de governança e processos da própria ou governo de comunidade que realizou o organizações indígenas.

É assim como este trabalho procura contribuir para a compreensão da gestão e governação dos territórios indígenas coletivas na pesquisa da Colômbia está estruturada em três capítulos que correspondem à divisão da redação deste texto. Primeiro, descreve a história do processo de contato e relacionamento entre a nasa e a sociedade envolvente que você configurou o sistema interétnico, em que a pesquisa é realizada. Num segundo momento, a descentralização da administração 
pública local e "participação especial étnica" é explorada nos recursos da nação através da vinculação dos guardas para o SPG, para a implementação dos direitos territoriais culturais reconhecido pela constituição de 1991. Finalmente como estudo de caso, focaremos nosso olhar sobre a experiência da gestão de pessoas da nasa e governança local da vinculação das muralhas de San Francisco, Toribío e Tacueyó, que compreende o território do município de Toribío de GSP. Em que irá revelar as tensões, mal-entendidos ou fricções interétnicas como expressão de toda constelação jurídica e política dos efeitos da refundação da nação colombiana.

\section{Trabalho de Campo}

La informações apresentadas aqui é o produto do trabalho de campo em territórios coletivos dos resguardos indígenas nasa San Francisco, Toribío e Tacueyó no município de Toribío no departamento de Cauca (sudoeste colombiano), durante os meses de setembro a novembro de 2014 e esporádicas visitas durante o mês de dezembro do mesmo ano e janeiro de 2015.

Da mesma forma após a segunda semana de novembro a primeiro de fevereiro do corrente ano, realizada principalmente na biblioteca Mario Carvajal da universidade do Valle, na cidade de Cali na Colômbia, uma revisão exaustiva da literatura. Antes do início das atividades do trabalho de campo, entrei em contato com alguns amigos da nasa, que faz parte do programa de etnoeducação como professores do centro de educação, formação e investigação para o Desenvolvimento Integral da Comunidade CECIDIC, então eu guio a solicitação para um encontro com o tradicional ou as autoridades comunitárias.

Uma vez que a proposta de pesquisa foi socializada com membros da Associação dos conselhos indígenas do município de Toribío, foi proposta para integrar-se como um professor a etno-educação da equipe de CECIDIC, em substituição de um colega que estava de licença maternidade. O que significativamente facilitado as atividades de coleta de dados, desde que esta passagem de atividade a desenvolver o papel de investigador-universitário o ensino, o papel que me permitiu acessar diferentes espaços como mingas, assembleias e reuniões. Da mesma forma me reconhecer membros da Comunidade como um professor eram mais acessíveis para me ajudar e me dar informações.

No desenvolvimento do trabalho de campo teve um número de dificuldades relacionadas com a difícil situação vivida por essa população pelo conflito armado que se realiza em seu território ancestral há mais de 50 anos e que deixou em seu rastro uma série de vítimas e danos 
materiais. Devido à sua localização geográfica, as condições topográficas do território e a históricas causas estruturais da pobreza e a marginalização, o município de Toribío tem sido um epicentro da presença de atores armados legais e ilegais e cultivos ilícitos ciclicamente.

É um dos municípios com o maior número de confrontos e assédio entre forças militares e grupos insurgentes, especialmente as Forças Armadas Revolucionarias de Colômbia-FARC. Como mencionado pelo plano de desenvolvimento municipal de 2012 - 2015

Um mais remotos municípios longe geograficamente dos centros de decisões políticas, a situação de grave crise humanitária (deslocamento, mortes, ataques indiscriminados a civis e danos a propriedade civil, etc.). Para enfrentar os guerrilheiros das FARC, que tornou a presença no município, as forças policiais permanecem na cidade e forças militares nas zonas rurais, colocando em grave risco a população civil sempre que há um confronto entre estas. (PREFEITURA MUNICIPAL DE TORIBIO, 2012, P.30)

Apesar do fato que já estava na pesquisa indígena territórios anteriormente em outros momentos, 8 anos, setembro foi desenvolvido nesse trabalho de campo em casa tinha dois 2 anos sem torná-los, e encontro-me com um aumento na militarização do território pelo exército e vários grupos armados que aumentaram a violência na região. Da mesma forma, gerou-se um aumento de cultivos ilícitos que trouxe a deterioração do tecido social. Por esta razão, fazendo pesquisas em muitas áreas rurais da Colômbia como o Cauca, tem uma conotação particular que se tornam o trabalho de campo potencialmente perigoso e segurança pessoal em um assunto de grande importância.

Estar imerso em um conflito armado de antigo e complexo sociedade colombiana, o exercício da pesquisa traz implicações metodológicas, políticas e éticas. A violência que tem caracterizado o departamento de Cauca e em particular para o município de Toribío nas últimas décadas gerou um clima de insegurança pessoal e fragmentação do social tem que tornar a vida menos previsível e mais restrita, colocando em evidência o trabalho de campo é inerentemente perigoso ao pesquisador.

Que durante o trabalho de campo realizado teve que antecipar e definir os perigos, não só pela minha integridade, mas também para aqueles com quem eu trabalhava. Situações como 
confrontos militares ou o aumento na presença de membros do exército e as FARC bloquearamme em muitas ocasiões viagens para lugares onde tinha agendada uma reunião ou participação em uma atividade da Comunidade Tube que modificar o calendário projetado para trabalho de campo e limitaria as possibilidades de obter as informações primárias necessárias para pesquisa.

Durante os meses de setembro a novembro de 2014, bem como servir como professor de educação básica na área de ciências sociais, participar de diferentes atividades, tais como reuniões, reuniões do grupo de etno-educação, trabalho mingas, memoriais, atos rituais de "Harmonização" e "arrefecimento., demonstrações, workshops de formação entre outros Durante o primeiro trabalho de campo, focado na busca de informações que me permitiria conhecer a experiência dos guardas do município de Toribío na administração e governança local dos territórios indígenas coletivas do seu link para o sistema geral de participação. Então ele decidiu que deveria começar a entrevistar os líderes dessa comunidade tão bem quanto vê pertenciam ao gigante como uma autoridade tradicional, dirigido a administração municipal como prefeito, então ter sido no dilema entre o seu papel como um funcionário público estado e suas raízes comunitárias como líder e autoridade tradicional.

Atingir 3-entrevistando pessoas que conheça esta condição e atualmente ainda ligado a organizações comunitárias ou instituições públicas locais e regionais. Entre as entrevistas feitas s o mencionado e outros 6 estão com pessoas consideradas chave, como alguns membros dos conselhos ou programas do projeto da nasa e outros que pertencem aos setores religiosos, acadêmicos, organizações populares, entre outros, que tiveram ou têm relacionamentos com as pessoas da Nasa do norte do Cauca e especificamente ao município de Toribío.

É importante notar que, no meu estado do ensino e no âmbito das atividades relacionadas com o desenvolvimento do projeto comunidade etnoeducativo foram realizadas 2 grupos de foco, com jovens estudantes que fazem partes das escolas do município e outro com os professores e membros dos três guardas, que permitiu revelar o que as pessoas percebem de diferentes instituições, como o cabildo guarda indígena, o projeto da Nasa, mas também o gabinete do prefeito, a polícia, o Conselho e outras instituições, grupos ou organizações que fizeram presença no território, e que fornecem ou não com suas ações para a administração e governança local. Participação em eventos comunitários, tais como a Assembleia Geral do projeto que NASA realizada em San Francisco, comunidade de guarda de trabalho do mingas semanalmente, o 
Assembly de justiça própria, na qual ele foi julgado e condenado a sete guerrilheiros que admitiu ter participado no assassinato de dois guardas indígenas, a comemoração do dia dos mortos, fornece guarda de controle territorial e outras atividades em que participar durante o campo de trabalho permitiram-me a experimentar o todos os dias pessoas nasa Agência e/ou complementar as informações obtidas através de entrevistas e grupos focais.

\section{Abordagem teórico-Metodológico}

Desde, a abordagem metodológica utilizada para a elaboração desta dissertação foi adotado pelo uso de técnicas para a coleta de informações como a entrevista semiestruturada ou aberta, grupos focais, observação participante e análise documental. Tentando obter informações quantitativas e qualitativas, necessárias para o desenvolvimento da pesquisa. O material bibliográfico utilizado está relacionado com vários produtos de documentos de pesquisa na Colômbia-indígenas e a nasa relacionados em especial, artigos publicados, livros, papéis ou dissertações de mestrado e graduação formato de tese. De igual forma, recorreu a documentos emitidos por organizações indígenas e instituições Estatais. Dado que eu considero que o cenário econômico, político e cultural em que esta dissertação foi desenvolvida é o resultado de uma interação complexa de relações interétnicas que definiu a história nacional da Colômbia. Eu inclinado para lidar com as relações do estado com a Comunidade nasa do município de Toribío na administração e governação dos territórios indígenas, a partir da teoria da identidade étnica e a noção de fricção interétnica do antropólogo brasileiro Roberto Cardoso de Oliveira.

Influenciou teoricamente por Fredrik Barth e Abner Cohen (1997) para Cardoso de Oliveira etnicidade é essencialmente uma forma de interação entre grupos operando no interior de contextos sociais comuns que envolve relações entre coletividades no interior de sociedades envolventes, dominantes, culturalmente hegemônicas e onde tais coletividades vivem a situação de minorias étnicas ou, ainda, de nacionalidades inseridas no espaço de um Estado-Nação (1997, p.12).

Essas ideias de Cardoso de Oliveira, Oliveira Filho (2006) afirma que o

a etnicidade supõe, necessariamente, uma trajetória (que é histórica e determinada por múltiplos fatores) e uma origem (que é uma experiência primária, individual, mas que também está traduzida em 
saberes e narrativas aos quais vem a se acoplar) (Oliveira Filho, 2006, p.79).

Para os antropólogos como Roberto Cardoso de Oliveira e o argentino Roberto Ringuelet história de um grupo étnico é fundamentalmente uma história de relações no contexto de situações de fricção interétnica que devem ser relatados no contexto em que. Sobre Roberto Ringuelet menciona que "a história de um grupo étnico, é a história de sua" carreira "dentro da sociedade inclusiva com suas orientações centralizadas e sua concepção particular de classe e etnia" (Ringuelet, 1987, p.32).

Através do desenvolvimento histórico das relações interétnicas em relação a grupos étnicos constituem uma representação de se na situação onde eles estão, o que significa que a identidade étnica varia de acordo com as situações ou histórias das relações interétnicas. Oliveira Cardoso considerou que essa etnia dá conta das relações e observáveis representações em contextos marcados pela interação cultural diferentes. Em lidar com o grupo étnico como "um classificador que opera no interior do sistema interétnico e a nível ideológico, como resultado de representações coletivas, polarizada por grupos sociais em oposição latente ou manifesto" (CARDOSO DE OLIVEIRA, 1992, p). Nesta perspectiva, os processos de identidade étnica não é gestado através de contradições, mas a partir de oposições, a considerar a etnia

um conceito relacional, uma relação, nacional, as populações são transformadas em grupos étnicos apenas quando eles são inseridos em grupos minoritários, ser guiado por ideologias étnicas (ou raciais) e investir com identidades sociais de contraste marcado por símbolos étnicos. (CARDOSO DE OLIVEIRA, 1992, p.102).

As identidades étnicas, como representação coletiva organizaram a maneira de pensar e agir de um grupo humano, porque, desde a coerência a uma visão do mundo. Esta natureza essencialmente comparativa da identidade étnica é um dos elementos do qual ele é definido. Para considerar que a identidade étnica como forma logo tão ideológica de representações coletivas de uma sociedade, é um caso particular de identidade social e uma forma ideológica de representações coletivas de um grupo étnico específico. Que define a identidade étnica das relações do grupo dentro e como estes estão relacionados com outros grupos sociais, isso significa que eles estão em relação, porque nenhum grupo social você pode conceber ideologicamente se 
não percebida a existência de outro grupo.

Quando um grupo ou uma pessoa definida como tal, eles fazê-lo como um meio de diferenciação em relação a qualquer grupo ou pessoa a que eles enfrentam, é uma identidade que surge a partir da oposição, que não pode ser dito de forma isolada. Oliveira disse que a identidade social "supõe relações sociais então quanto um código das categorias projetado para Oriente ou desenvolvimento destas relações" (CARDOSO DE OLIVEIRA, 1976, p. 5). Esse código é manifestado como o sistema de oposição ou contraste, ou seja, identidade é construída em oposição a outra, com a experiência de um grupo de contato com o outro.

Um indivíduo ou grupo indígena afirma a sua etnia contrastando-se com uma etnia de referência, tenha ela um caráter tribal (por exemplo, Terêna, Tikúna, etc.) ou nacional (por exemplo, brasileiro, paraguaio etc.). O certo é que um membro de um grupo indígena não tem sua pertinência tribal a não ser quando posto em confronto com membros de outra etnia. Em isolamento, o grupo tribal não tem necessidade de qualquer designação específica (CARDOSO DE OLIVEIRA, 1976, p.36).

A natureza contrativa destas identidades são, portanto, um atributo essencial da identidade étnica, assim, a identidade étnica aparece como uma identidade decorrentes a oposições identidade étnica precisamente verificação capacidade permitindo a operar como um sistema de referência ideológica em contextos Inter tribais ou interétnicos.

Em quais unidades étnicas salvou relações de contradição e tendo lugar no campo de uma estrutura de classe (por exemplo, negros e brancos em um contato sistemático e contínuo, que ocorre no alto rio Solimões entre o tikuna e brasileiros na região (CARDOSO DE OLIVEIRA, 1992, p.59).)

Sendo a identidade étnica formado a partir de um processo de verificação, mas principalmente de confronto com o outro, ele não é possível analisar independentemente as relações inter-étnicas, uma vez que são os espaços de interação temporal onde é a Agência e reinventa a identidade.

Etnia não é mais definida por si, mas como uma entidade que emerge as 
diferenças culturais entre grupos que interagem em um determinado contexto de relações interétnicas (Poutignat, Streiff-Fénart, j.; 1997: 82.) Citado por BARI, 2002, Pirola)

Relações interétnicas causaram uma cultura de contato que gera a identidade étnica para afirmar-se em sua persistência através do processo de mudança cultural.

Neste sentido, esta cultura de "contato" pode ser mais do que um sistema de valores, chegando a ser o conjunto de representações (que também inclui valores) a um grupo étnico, construída sobre o local de contato, no qual ele está imerso, e em termos de qual é classificado (identifica) ele mesmo e outros é confidencial. (CARDOSO OLIVEIRA, 1976, P. 14)

O contato interétnico incentiva esta forma de identificação, lançando os mecanismos sociocultural consistentes nos discursos e práticas que os povos indígenas são amarrados juntos dentro e nas suas relações com a sociedade circundante. Um grupo social é definido ou é identificado como étnico, com práticas e símbolos culturais de outros grupos e que são representados interage com aqueles que elas representam. Então este caráter étnico é fortemente determinante nas áreas de fricção interétnica. Nas áreas de contato interétnico grupos étnicos em interação reafirmarem suas respectivas identidades através de um sistema de representação é construída nas relações interétnicas.

Para alcançar uma melhor compreensão do processo de identificação étnica, Roberto Cardoso de Oliveira propõe a noção de "Contrastando identidade." Estas relações interétnicas são o produto de situações envolvendo grupos sociais com relações de poder assimétricas. Que fazem parte de um sistema interétnico que configura uma totalidade sincrética, na situação de coexistência de diferentes práticas culturais dentro de um espaço territorial, "entre duas populações dialeticamente unificada através de interesses diametralmente opostos, mas paradoxalmente interdependentes" (CARDOSO OLIVEIRA, 1981, p. 26).

De acordo com Roberto Cardoso de Oliveira os sistemas interétnicos está formados por relacionamentos entre duas populações dialeticamente ligadas através de interesses diametralmente opostos mas interdependentes, paradoxal que possa parecer. É uma oposição. Ou o que é o mesmo, uma contradição entre sistemas corporativos em contradição, 
portanto, passado para formar parte de um mais abrangente que pode ser chamado de "sistema interétnico. (CARDOSO DE OLIVEIRA, 1968. Citado por VAZQUEZ, 2000 p 47)

Desde que, neste tópico o estudo da identidade étnica deve considerar a situação social e política dos atores relacionados e seus respectivos interesses, Cardoso de Oliveira (1976) chamado sistema interétnico, ou seja, um sistema de relações entre grupos étnicos e a sociedade nacional em um contexto intercultural que se manifesta. Relações que ultrapassam a sujeciondominacion, cooperação, competição e conflitam entre pessoas culturalmente diferentes, desde que eles representam uma oposição ou contradição entre sistemas corporativos interagindo para constituir um sistema interétnico vinculação subsistemas. Que devem ser analisados no âmbito do sistema interétnico que faz parte e onde estão os outros mecanismos de disposições estruturais ou sociais comuns.

As relações interétnicas só podem ser rendosamente apreendidas se inseridas num sistema social de carácter interétnico, que as condiciona, determinado sua própria estrutura y desenvolvimento; em segundo lugar, que esse sistema interétnico, constituído por processos de articulação étnica, não pode prescindir de ser referido a processos de articulação social de outro tipo, como os que relacionam outros setores da sociedade global, seja os inter-regionais, os intercalasses ou mesmo ligam os setores rural e urbano (CARDOSO DE OLIVEIRA 1976, p. 53).

Acordo, Cardoso de Oliveira, os subsistemas têm entre se e o sistema interétnico, constituindo, a mesma correspondência lógica que tem entre se global ou nacional sociedade e classes sociais. Neste sentido, da mesma forma que examina a sociedade nacional através da sua estrutura de classe, etnicidade é tida como um resultado das relações interétnicas dentro de um processo de constituição de classe dentro de um estado-Nacion.

Asi as relações é interpretado, que se as classes são explicadas das relações sociais de produção, em uma sociedade de classes, em que há uma estrutura dominante que contém as unidades de diferentes minorias étnicas classe condição relações direta ou indiretamente de relações interétnicas, em torno de um eixo dinâmico de exploração e dominação 
social e económica (VÁZQUEZ, 2000, p.159).

Oliveira Então acredito que a noção de fricção interétnica como um equivalente lógico mas não ontológica da luta de classes no estudo das relações interétnicas. Uma vez que torna inteligíveis as relações de natureza conflitante entre grupos étnicos e segmentos locais e regionais da sociedade, como parte de um processo de articulação social geral, onde a natureza antagônica dessas relações, supõe um sistema interétnico consistindo de mecanismos de articulação onde há um conflito latente ou manifesto.

Um sistema social susceptível de ser analisado através de sua estrutura de classe. A situação de contato, graças ao sistema de relações que lhe é inerente, pode ser analisada graças ao que chamarei Fricção Interétnica o que será o equivalente lógico, (mas não ontológico) do que os sociólogos chamam "Luta de classes". Convém ao analista decifrar a estrutura deste sistema e sua dinâmica para fornecer um diagnóstico e tentar estabelecer um prognóstico da situação de contato (CARDOSO DE OLIVEIRA, 1978a, p. 85).

De acordo com Díaz Polanco (1995) etnia deve ser considerada, dentro da classe de sistemas, tais como uma dimensão ou nível de classes sociais, ou seja, formando parte da superestrutura, juntamente com os níveis jurídicos, ideológicos e políticos." Nesta perspectiva seria possível saber a mediação do poder no local de cada "grupo" na estrutura social e políticas e ideológicas de identificações que reproduzem a estrutura social "(CARDOSO DE OLIVEIRA, 1982. Citado por VAZQUEZ, p.38 2000).

Com a noção de fricção interétnica Roberto Cardoso busca

enfatizar a natureza conflituosa das relações interétnicas, modelado por uma estrutura de sujecion-dominacion. Essa estrutura, na verdade, é uma réplica no avião étnico (es decir das relaciones interétnicas) da estrutura de classe que existe no nível social global (ou seja, da estrutura nacional inclusiva). Significa que unidades étnicas em contato foram relações de contradição no sentido de que a existência de uma das unidades nega a existência do outro, pelo irreconciliáveis de sua posição no interior do sistema interétnico. (CARDOSO DE OLIVEIRA, 1992, p 64) 
A Fricção Interétnica como concepção sistêmica da oposição relacional para o interior de um sistema interétnico centra-se "nas relações que existem como populações naturais ou entre sociedades relacionam" relações interétnicas (CARDOSO DE OLIVEIRA, 1978, p. 85), sistema que opera em três níveis, económicos, sociais e políticos, cada uma delas expressar aspectos parciais da situação de contato, que deve ser considerado juntos. (CARDOSO DE OLIVEIRA, 1978)

Estes elementos do sistema interétnico são abordados por Cardoso de Oliveira, da noção do potencial de integração, quais são as características do sistema interétnico que podem ser considerados como elementos que favoreçam a integração dos povos indígenas na sociedade regional e nacional. A proposta do modelo do sistema interétnico visa compreender os mecanismos de integração que a agência de três diferentes níveis atrás referida. Integração social é um dos três níveis que fazem parte do sistema interétnico para esta teoria. Neste sentido, o nível económico mostra o grau de dependência dos índios aos recursos económicos provenientes de sociedade nacional ou regional e o grau de dependência da sociedade nacional ou regional de recursos que os índios têm.

Para Oliveira está dependência ou interdependência tem grande poder explicativo, porque é o produto de não-existente precisa de contato. A capacidade dos diferentes grupos em contato de manter um mínimo de organização própria, permitindo-lhe caçar e mobilizar seus componentes e orientar suas extremidades como grupo social é o que se busca com o estudo do nível social. Em termos de política procura saber os meios ou mecanismos pelo qual diferentes grupos contatos atingir seus fins. Que revela a natureza do poder ou a autoridade de um grupo sobre outro e referese à estrutura de poder do sistema interétnico.

Para o antropólogo Renato Athias (2007), Roberto Cardoso de Oliveira, com a teoria da identidade étnica e sua noção de fricção interétnica, tentar:

1) Fornecer uma estrutura teórica para a explicação e a compreensão da situação de contato; 2) chamar a atenção para os aspectos dinâmicos desta situação;3) confrontar a natureza dialética do fenômeno. Ele vê o fenômeno do contato como uma totalidade unificada por interesses opostos (ATHIAS, 2007, p.114).

De acordo a Cardoso de Oliveira, "mais que um estudo da mudança cultural, queremos 
estudar a mudança social, sobretudo com o estudo da mudança de situação" (CARDOSO DE OLIVEIRA,1979, p. 37).

A identidade étnica e interétnica Roberto Cardoso noção de fricção nos permite estudar as relações das pessoas nasa do município de Toribío e o Estado colombiano no exercício de diferenciais culturais direitos concedidos a indígenas pelo 1991.Como multicultural Constituição verá ao longo desta dissertação que incide sobre a gestão e governação dos territórios indígenas coletivas ao município de Toribío da vinculação dos guardas como entidades territoriais transitórias de natureza especial para o Participação em geral da administração e sistema de gestão pública local, não só apresenta uma interpretação divergente dos procedimentos orientada para garantir o direito de governar os territórios indígenas, de acordo com os usos e costumes da Comunidade que habita-los, mas concepções em frente a formas de pensamento e governar o território entre o estado e os povos indígenas.

Limitações estruturais e divergências interpretativas dos direitos territoriais culturais apresentados nos próximos capítulos revelam as tensões existentes na colisão de visões e práticas relacionadas à gestão e governação dos territórios indígenas entre a nasa pessoas e instituições do estado o estudo de caso. Esta situação considerá-lo uma fricção interétnica de acordo com a noção do antropólogo brasileiro Cardoso de Oliveira apresenta-se como teórico de referência desta dissertação. Na oposição de dois modelos organizacionais com temporalidades, formas de organização social e visões de mundo diametralmente, que surgem a nível local, sob a forma de organizar a gestão e administração pública em territórios indígenas.

A noção de fricção interétnica permite-nos tornar inteligível as condições e as tensões ou conflitos na administração e governação dos territórios indígenas do município de Toribío, do potencial para a integração do regime tecnocrático de tutela que o estado impôs-se sobre o direito dos povos indígenas de governar seus territórios de acordo com suas tradições e costumes.

Para o imposto de parâmetros culturais dominantes da sociedade para a definição das práticas de governos indígenas, pesquisador líder Edmundo Pereira (2014) a considerar a implantação ou implementação dos direitos culturais relacionados a territorialidade e autodeterminação indígena que é parte de guardas indígenas como ligação de entidades territoriais de caráter especial e de transição para o SPG deve ser "também entendidos como processos de acondicionamento cultural, de redefinição e maior formalização de parâmetros socioculturais 
considerados como próprios ao grupo social. No caso, através da definição do que sejam, afinal, "usos e costumes" (Edmundo Pereira, 2014, p.4). 


\section{CAPÍTULO 1 - OS FILHOS DA ÁGUA E AS ESTRELAS}

Neste primeiro capítulo abordare a história do contato interétnico da nasa pessoas sociedade surround que define o local do sistema interétnico que se desenvolve esta dissertação. Jornada histórica que leva até o histórico deste povo, que é dos principais do ator colombiano movimento indígena. É necessário mencionar que a função desta abordagem histórica no contexto global da pesquisa, é perceber que as divergências e divergentes propostas apresentadas na gestão e administração pública em territórios indígenas, em que a dissertação está focada é a historicidade de relações interétnicas do povo da nasa e produtos da sociedade de vinculação.

E não simplesmente uma rejeição ou reação a adversidade representada por forças além de seus interesses, para a elaboração da proposta de autonomia política sua Assembleia pelo povo nasa do município de Toribío no processo de luta e resistência de mais de quatro séculos de povos indígenas colombianos. Em primeiro lugar, apresento um trecho do mito de origem do povo da nasa, compilado e publicado por um dos seus principais linguistas Marcos Yule (2003) e continuou mencionando algumas das hipóteses existentes sobre a origem da nasa.

Então reconstruí a história do nasa pessoas de contato com surround ou vinculação a sociedade desde o início da empresa espanhola usurpadora até a Constituinte de 1991 que ocorrem as mudanças constitucionais, que reconhece os povos indígenas o direito de governar seus territórios de acordo com suas tradições e costumes. Finalmente chegou a uma conclusão deste primeiro capítulo a concepção histórica na memória coletiva da nasa aldeia e seu uso político.

De acordo com sua cosmovisão, a Nasa são um filho de povos indígenas, da água e as estrelas, seu mito de origem diz que "água (YU’), filho de terra (KIUE) e sol (SEK) é encontrada para as estrelas $\left(\mathrm{A}^{\prime}\right)$ que tinham vindo à terra buscando casal. "Estrelas casaram-se com água e criou uma avalanche de que nasceu a Nasa atual, YU'LUC' água e estrela criança." (YULE, 2003, BUNYARD). 
Para alguns pesquisadores, os povos indígenas Páez ou nasa ${ }^{1}$ é produto da fusão précolombiano ou intercultural assimilação das diferentes comunidades que estavam em treinamento através de conflito interétnico.

"Pelo menos ele indica as cinco principais variações dialectais da língua, as diferentes características fenotípicas e míticas versões de sua origem". (GOMEZ; RUIZ, 1997, p) esta hipótese considera que o povo da nasa é descendentes de comunidades que veio de florestas tropicais para o alto vale do Rio Magdalena, na cordilheira central dos Andes no século XIV, por razões que são desconhecidos. Não o seu origem Andina é baseada na semelhança de cosmovisões e práticas deste povo com algumas comunidades que habitam as florestas tropicais e a ausência de um sistema de autoridade hierárquica que foi encontrada nas etnias andinas. (Ver FINDJI; ROJAS, 1985; GOMEZ; RUIZ, 1997; BONILLA, 1980)

P. Rivet e R. Ismael em sua antiga etnografia da Equador localizado Páez ou Nasa Yuwe pertencente à família linguística chibcha do churrasco subgrupo.

As afinidades do idioma são na sua maioria muito claras com os dialetos Chibcha da América central. É também com a línguas paniquita e kokonuco, falada no sul da Colômbia por Páez, o paniquita, o totoro, o kokonuco, o moguex, guanacos e pijaos, alguns destes povos tinha preservado a memória da sua origem. Com efeito, falando sobre migrações vem da América Central, e aqueles que vieram do Panamá através do porto de Buenaventura veio Pijaos e Paranhos. (REBITE; VERNON, 1906. Citado por OTERO, 1952)

Com o nome de paniquita ou Paez ' ter nomeado um grupo de dialetos relacionados, que aqueles são ainda faladas e outros falavam no território incluído no alto Cauca e Magdalena alto. " (OTERO, 1952) No entanto, estudos posteriores consideram que Nasa Yuwe ou Paez e outras línguas andinas são muito diferentes em sua estrutura e no seu léxico, o que parece improvável a hipótese de uma origem comum. Desta forma, elas aparecem como uma língua isolar que

\footnotetext{
${ }^{1}$ Os nasa foram chamados da época da conquista como Paeces, nome que foi baseado em uma aproximação espanhola do nome de um cacique nasa que viveu no tempo da invasão espanhola. Durante as últimas décadas, no entanto, em um processo de reinvenção cultural nesta cidade decidiu chamar-se como a nasa, nome que deriva de sua própria língua (nasa yuwe). Neste texto que vou fazer uso deste conceito para referir-se a eles, exceto quando ele aparece citado por outro autor como Paez.
} 
dificilmente pode ser classificado como uma língua independente, embora em comparação com outras línguas extintas. (Ver YULE; ROJAS; NIEVES, 1991; GORDON, 2005; ARIRUMA; SILVA, 2005)

\subsection{Os Nasa no período Precolombino}

Os nasa durante o período precolombino ocupou a cordilheira central na parte entre as bacias do nevado de Huila e Puracé, estendendo-se para o outro lado da colina, com uma presença maior na bacia hidrográfica do Rio Paez. Contavam com uma organização social e política com base em grupos de parentesco com ascendência mítica comum que eram governados por chefes que subdividem suas chefias em unidades menores realizadas pelas autoridades líderes locais ou políticos conhecido como chefes menores. Para descrever esta organização políticos territoriais espanhóis usaram como nomes de lugar os nomes dos chefes supremos.

De acordo com diluído (1956 [1575]) da nasa durante o século XVI, eles foram organizados em três unidades de políticas regionais, vindo de tempos pré-colombianos: Paranhos (ao norte, ao longo da parte superior do Rio Paez), Abirama (para o Sul, na parte inferior do Rio Paez) e Suyn (na Cuenca do río Moras).

Sob a autoridade dos três chefes suprema existia outros líderes políticos referidos como chefes menores.

De tarabira uma Índia principal, irmã do senhor de Paranhos, Talaga e Simurga, foi a senhora principais índios e chefes na terra: todos estes viés diferente do que Abirama, porque Abirama sustentado guerra por si só e Esmisa, com Suyn, seu pai, eram chefes de outro viés, de sorte que estes três parcelas tinham nesta província cujo diretor é arrimavam e seguiu os outros chefes da terra, como cada um parecia (Aguado 1956 [1575?]: 518519).

Acordo, para os registros dos primeiros jesuítas que entraram na região de Tierradentro, havia mais vinte e quatro chefes entre menores e maiores no momento da chegada. (Ver Hazañero1645).

Um imposto ao final dos registros do século XVII inclui mais de 28 caciques e diretor em Tierradentro, que indica que cada um deles tinha a 
subordinação de uma média de sessenta a oitenta pessoas. Fontes coloniais apresentam um labirinto de termos inadequadamente definidos que correspondem mais a uma terminologia europeia que uma nasa corretamente. Os chefes menores são comparados nestes documentos, com o principal e são considerados intermutáveis com eles, misturando-se, bem, diferentes níveis de integração sócio-política. Os cronistas associados com líderes políticos, com população de unidades ou territoriais chamadas «preconceito», que eram nunca claramente definidas. (RAPPAPORT, 2000, p. 63).

Mas apesar desta encontrado fontes coloniais fornecer uma abordagem para a natureza da chefia neste período.

Um registro do século XVII sobre imposto nasa das encostas ocidentais da cordilheira central inclui o chieftain Toribío Tobalo (filho do cacique Tierradentro Talaga), que tinha cento e vinte temas. Talvez Tobalo colonizou o Western a mando de seus pai de encostas, embora também poderia ser que tinha abandonado Tierradentro para não ser capaz de consolidar o seu poder nessa área. Pode ser que os chefes supremos de Tierradentro eram na verdade filhos de chefes de prata da nasa, enviadas para o planalto de Tierradentro para fundar assentamentos de fronteira. (RAPPAPORT, 2000, p. 64).

Não havia entre eles uma classe social dominante ou senhores que estavam com medo, então odeia lotação e assunto, sabido é que, como seus aliados e vizinhos, o Paeces e guanacos, as tribos do alto Magdalena não vivem em aldeias compactas, mas no isolaram habitações espalhadas em toda a região. (FRIEDE, 1974, p.92)

A dispersão como padrão de assentamento correspondia a uma estrutura social de cluster livre em torno de um chefe ou chefe, que carecia de domínio autocrático sobre os membros do grupo e apenas no caso de um confronto com outros povos se juntaram e aliados fornecendo uma única cabeça. Uma vez o confronto de que cada grupo iria voltar a viver sem nenhum tipo de 
subordinação. Esta ausência de organização centralizada foi uma das características que se destacou a maioria dos cronistas para entender o comportamento político da aldeia da nasa.

De acordo com o modelo político-organizativo que precedeu a chegada dos espanhóis, chefes da nasa não exercido controle sobre a população que tinha em seu comando, nem recolhido tributo e não foram agrupado por proximidade geográfica ou por pertencer a um grupo de parentesco, para que nenhum deles tinha um grupo predefinido de seguidores. Para que a autoridade política pelo controle exercido sobre seus súditos, uma vez que seu poder era sujeito ao consenso do grupo não pode ser interpretado. No caso em que você exceder sua autoridade ou que fugir das suas obrigações iria ser abandonadas por seus súditos, exercitando o controle político sobre seus chefes. No entanto, os chefes da nasa tinham poder sobrenatural para ser encarregado de cerimônias e rituais xamanísticos.

O cronista Juan Velasco descreve a nação como enorme Paez e menciona que espalhados pelas cúpulas das montanhas e seus contornos, fabricado em casa sobre sanções fragosas e inacessível, então eles foram naturalmente defendidos dos seus inimigos. Os ídolos que encontrámos, temido e respeitado seus feiticeiros, que eram um pouco seus deuses, movendo-se de suas casas para cada passo por qualquer razão menor eram extremamente raras (Velasco, 1979 [1788]: p. 62). 


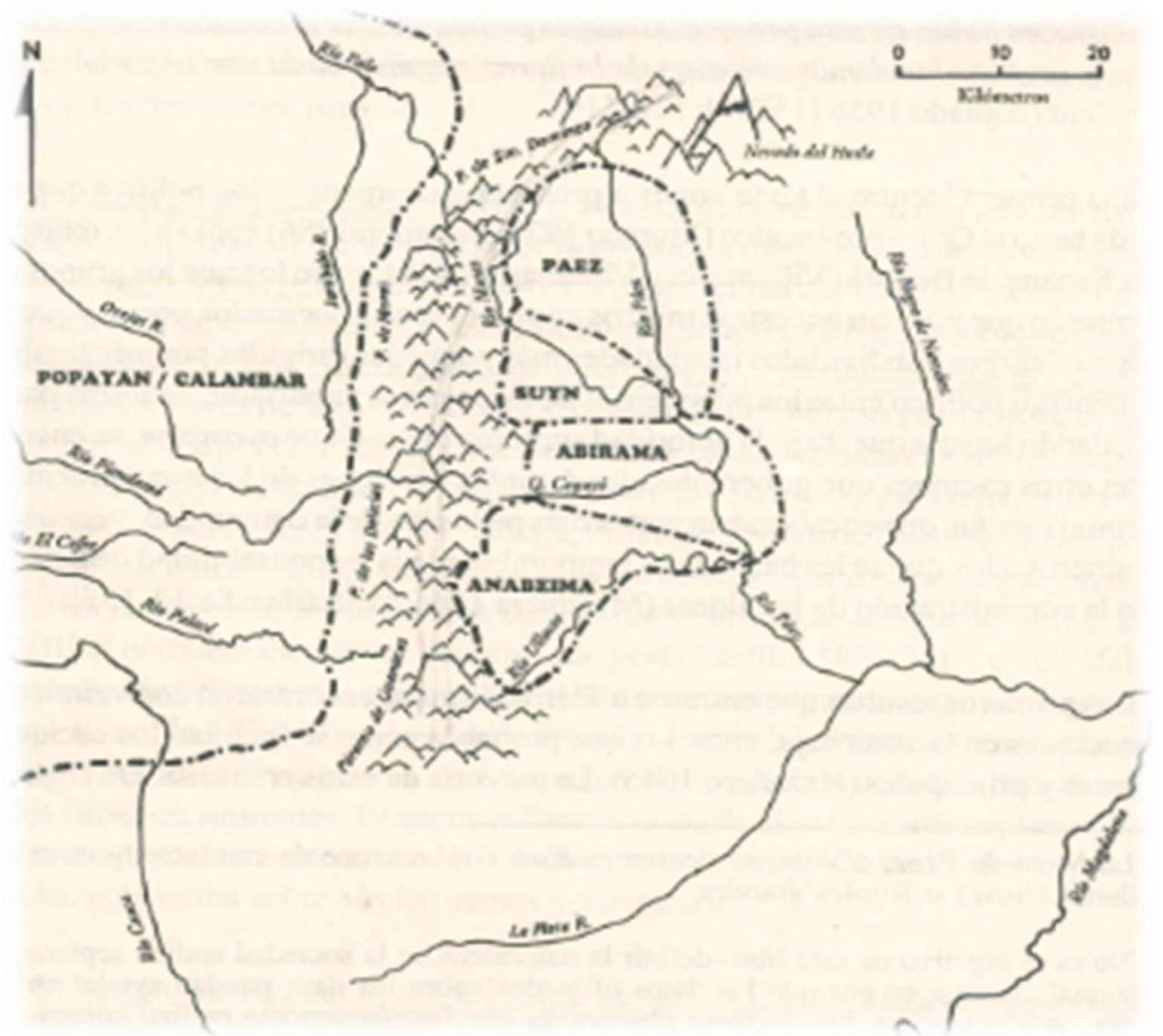

Figura 1 Principia-lhes chefias Nasa precolombino de Tierradentro ${ }^{2}$

Em resumo, chefias pré-colombiana da nasa foram um sistema político descentralizado que dependia o apoio e a aceitação de seus súditos. Esta organização sócio-política em contraste com a centralidade e a hierarquia política que eu caracterizaria seus vizinhos andinos, hierarquia e centralidade que facilitam a sua desmontagem pelos espanhóis.

Os assentamentos do vale do Rio Magdalena onde foram os nasa durante o período précolombiano foram multiétnica na natureza e esticado por um território que é compartilhado com o guanacas, pijaos e outros grupos indígenas pertencentes a famílias de línguas diferentes.

\footnotetext{
${ }^{2}$ Tomado de RAPPAPORT, 2000, p. 61.
} 


\subsection{Os Nasa e o processo de invasão da Europa Ocidental}

Uma vez alcançada a consolidação do assentamento espanhol em Quito o Capitão Sebastián de junior Belalcázar de Francisco Pizarro fez com que a expansão do processo de usurpação Norte América do Sul, envie para Juan de Ampudia e Pedro de añasco para sul oeste do território que conhecemos hoje como a Colômbia. Chegando em 1535 inicialmente para a província de séculos e mais tarde "Almaguer Popayan e Timana nas cabeceiras dos principais rios Cauca e Magdalena decrescente entre a cordilheira andina três" (FINDJI; ROJAS, 1985, p. 13).

Chegando a esta região os espanhóis observou que Andes centrais é cortada em sua jornada Sul em duas partes pela abrupta cadeia de montanhas que forma um assentamento humano de ambos os lados de existir no momento da chegada. "Altos cumes da cordilheira central separando os vales dos rios Magdalena e Cauca serviram como uma barreira natural para o Habitat das tribos do alto Magdalena para o nordeste e o oeste" (FRIEDE, 1974).

A cadeia montanhosa que compõem os vales e montanhas centrais encontrados espanhóis relativamente numerosas comunidades. "Cronistas e historiadores mostram que ocuparam uma região importante da etapa e manteve relações com a região do maciço para o Sul, bem como com a alta floresta amazônica, a leste" (FINDJI; ROJAS, 1985, p. 33). Rotas e formas de usurpação diferente no novo reino de granada são três tenentes de Pizarro, Jiménez de Quesada, Nicolás de Sebastián de Belalcázar e Federmann. Este último teria de enfrentar a belicosidade do povo nasa encontrou na conquista de sua empresa e que viria a se tornar seu maior obstáculo para atingir os objetivos.

Para conquistar a empresa espanhola, o território indígena localizado no vale superior do Rio Magdalena, a que o nome com o nome de Tierradentro, foi estrategicamente importante, já que era o direto natural rota entre a audiência real de Santa Fé de Bogotá e Quito epicentros principais do poder do Reino da nova granada. Os habitantes originais deste território, o povo da nasa e seus aliados - particularmente Pijaos (ver Valencia 1991) - não facilmente aceitar a conquista e resistir a invasão e a invasão espanhola de uma guerra de guerrilha.

É uma política e militar de resistência contra o invasor do seu território, os saqueadores da sua economia, contra aqueles que vieram para roubá-los, sua língua e cultura para impor o pagamento de tributo em ouro ou em trabalho, que, na história da humanidade, foi a expressão máxima do 
domínio político sobre um povo de fusão. Portanto, que os nativos lutaram constantemente contra esse domínio, indo para a máxima expressão da rejeição política: luta armada, a guerra contra o opressor. E a guerra foi longa e difícil (BONILLA, 1979, P.335).

Depois de fundar as cidades de Cali e Popayan, Belalcázar envia sua Juan de Ampudia Júnior e Pedro de Añasco para a conquista do alto vale do Rio Magdalena e a face ocidental da cordilheira central. No entanto, eles foram derrotados militarmente pelo povo da nasa que habitava estes territórios e vencer o mesmo Sebastian de Belalcázar, quando ela queria vingar a morte dos seus capitães, Cordilheira entre os dois rios se tornou palco de intensos conflitos. Quando ele foi a invasão espanhola de Tierradentro, realizada principalmente a partir da província de Popayán, em 1538, "o Paeces ofereceu uma resistência agressiva e teimosa, o que eventualmente levou à derrota dos Belalcázar Sebastian em 1542" (VAN DE SANDT, 2010, DDSs).

Apesar de seguir um padrão de povoamento disperso os potenciômetros foram concentrados em determinados pontos. De acordo com as crônicas de Juan Velasco (1977 [1789]) os nasa ocupou principalmente duas áreas diferentes, os prados do vale do Magdalena superior próximo a cidade da Plata, onde eles viveram a manutenção "menos rústica" intertribal relações estreitas com as planícies. E os bancos dos Rio Paez e curso baixo Rio amoras foi onde "mais rústica." Nesta região da sul oeste da Colômbia, existia um alto grau de interação e troca entre diferentes grupos étnicos que mantida a política e as relações comerciais. Diluído (1956 [1575]: 524) descreve o Tierradentro como uma região montanhosa, com planícies muito vistos e cultivadas, onde a caça era praticada amplamente.

Juan Velasco menciona a Fundação de San Sebastian da Plata em 1537 por Sebastian de Balcázar

tornou-se uma tribo da nação Paez, que como habitadora da parte inferior da Serra, foi menos rústico e barbara que os outros, e, portanto, era o único que poderia conquistar pelas armas, deixando os outros sem jugo e sem esperança de impor, naturalmente sendo defendida em sites muito quebrados e inacessíveis. (Velasco, 1979 [1788]: 65)

Em 1562, o Capitão Domingo Lozano foi capaz de encontrar a cidade de San Vicente de Paez no centro de Tierradentro. 
A Fundação de San Vicente de Páez, em 1562, confronta uma segunda geração de indígena com a conquista espanhola, mas St Vincent duraria apenas nove anos, até o ano de 1571 em que todas as tribos aliadas Paez deu um ataque os espanhóis, perecendo Capitão Domingo Lozano. Apesar de todos os reforços vêm de Popayán, soldados, armas e pólvora poderiam não contra a força do Paeces. Eles marcharam em direção de Popayán, destruindo estradas que relacionou-o com Cali. Corte, deixando a passagem entre os dois vale, alvo o Paeces concluída em 1577. A margem esquerda do Rio Magdalena estava livre e diz o cronista Juan de castellanos; Os Paeces com sua honra, livre de sujeição e servidão e liberdade, a menos que eles concordam que estranho habitante na sua província foram. (FINDJI; ROJAS, 1985, 19,23). 


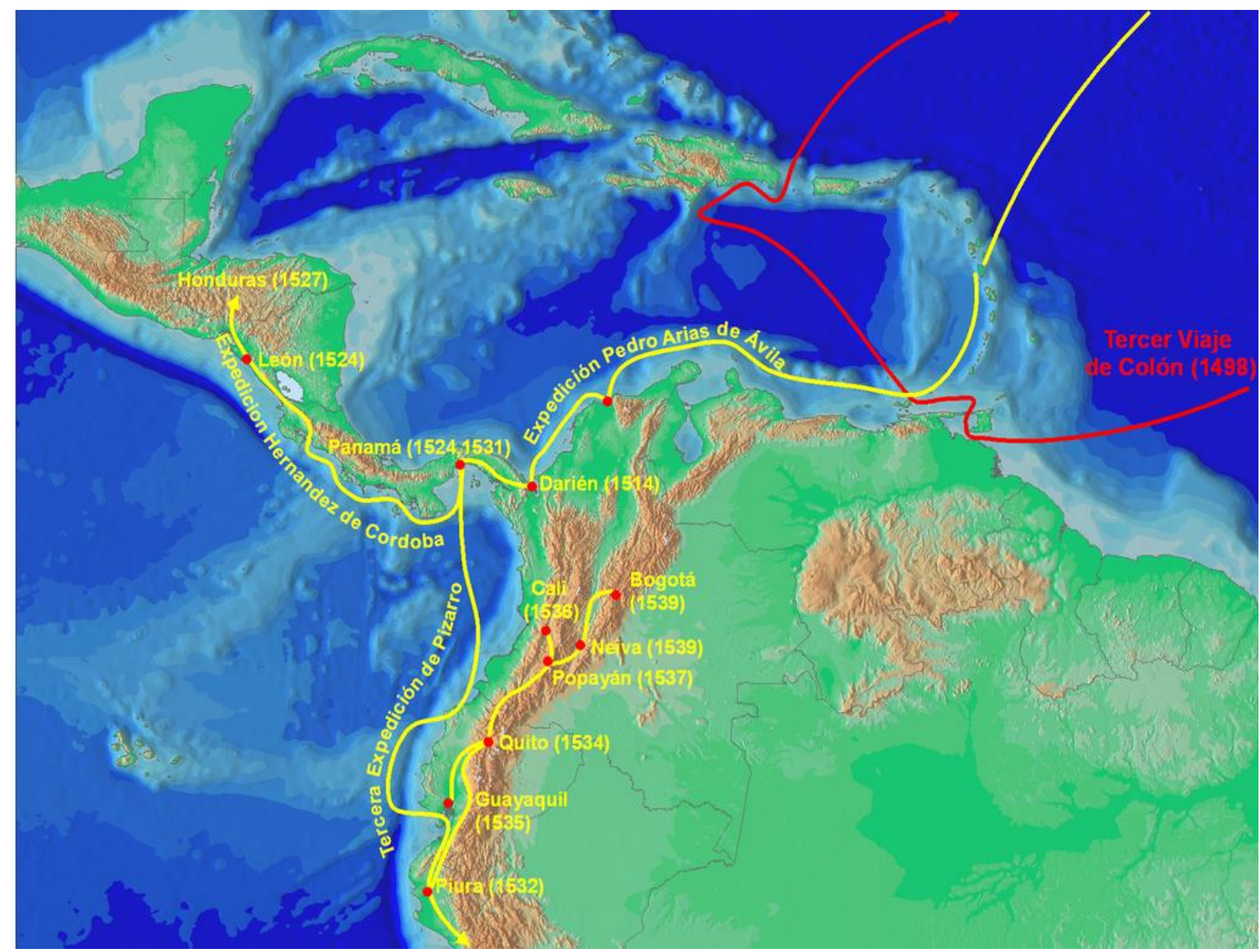

Figura 2. Algumas rotas de invasão espanhola. ${ }^{3}$

Com a derrota militar, os espanhóis foram forçados a retirar-se definitivamente Tierradentro depois a estrela dos nasa na destruição de grandes cidades de la Plata e nova Segovia de Caloto (ver Gonzalez, 1977; Roldán; Brown; Londoño 1975). Assim, já bem avançado a segunda metade do século XVI, o Paeces poderia com sucesso defendendo sua autonomia da empresa usurpadora sua montagem pelos espanhóis. Antes desta derrota, as ordens do governador de Popayán reencontraram a cidade de nova região Segovia para o interior para continuar buscando ajudar militarmente o Paeces. No entanto, mudou-se a cidade nova sobre o western inclinação da cordilheira central, erigindo-lo em 1582 o nova Segovia de Caloto no vale do Rio isabelilla na confluência do Rio vara e jambar isso.

Mas este novo local de Caloto nem duro, está ciente de que a "Guerra Indiana" esteve na cidade de armada e queimou a casa do capitão Pedro de

\footnotetext{
${ }^{3}$ Tomado de http://es.wikipedia.org/wiki/Sebasti\%C3\%A1n de Belalc\%C3\%A1zar. Visitado el 20 de junio de 2015.
} 
Moriones, em 1592; a tal ponto que, em 1594, os vizinhos da Nueva Segovia são todos os residentes em Popayán devido ao terror que infundem-lhes os ataques dos índios. (SENDOYA, 1975,)

No relatório apresentado por Francisco de Sande, para o rei de Espanha, em 1597, menciona que "entre dois rios Magdalena e Cauca-lá são cinco nações de índios de guerra que machucar onde, ao ponto que os habitantes eram em prata e Paranhos são oprimidos por esses índios de guerra." (FRIEDE, 1974, p)

Uma vez atingido os objetivos básicos da conquista do Reino de Nova Granada, a encomenda como figura político-organizativa é imposta para o controle e a subordinação dos povos indígenas que habitavam os territórios que queriam.

A encomenda era uma concessão real que foi concedida em reconhecimento das contribuições feitas aos interesses da coroa. Seu depositário receber homenagens em troca de uma série de obrigações que variado, estas variaram de assumir a responsabilidade para a conversão ao cristianismo, para defender a região militarmente (RAPPAPORT, 2000, p. 70).

Para pesquisadores como Findji e Rojas (1985) a encomenda é um corolário da conquista; legalmente não conferidos em particular, a quem foi concedido, mas se você deu a ele o direito de ter o controle político do território que era e obviamente para a exploração dos recursos existentes neles para o apoio dos ocupantes e os cofres do real.

Neste sentido, as primeiras acusações, emitidas no departamento de Cauca procuraram recompensar os mineiros e comerciantes que participaram ou financiados os confrontos com "o feroz Paeces" durante a prolongada guerra de resistência à conquista.

Os territórios entregues aos curadores seria imensos latifúndios de gado, porque não tinha como cultivá-las intensamente, devido ao declínio demográfico da força de trabalho indígena por confrontos constantes ou deslocamentos e os animais selvagens permitiram um controle territorial para impedir que eles foram cultivados por seus proprietários ancestrais que resistiram a desapropriação. Mas receitas através da tarefa exigida para reunir na estáveis assentamentos indígenas para facilitar a coleta e o controle. 
Essa política de concentração nas aldeias, a nasa responder a fugir para resistir sendo tributo. Ordenando os curadores principalmente para construir estradas ou manter aberto e transitáveis, infra-estrutura pré-colombianos que permitiu e facilitou a sua circulação, de impostos e o imposto. Existem muitos documentos que mencionam a existência de "Índios de paz ruim" que os curadores não conseguiram dominar e integrar na sociedade colonial, forçando-os a pagar tributo, fugindo de tributação e controle da sociedade colonial.

A imposição da encomienda em territórios nasa começou em 1640 e coincidiu com o surgimento de uma economia de mineração em Popayán e a expansão do sistema de financiamento em toda a região. (Ver Colmenares, 1979).

Para a destruição constante dos assentamentos e confrontos dos conquistadores e os povos indígenas do vale superior do Magdalena, que entre os quais estava a nasa, a coroa espanhola decidiu intervir diretamente, nomeando um experiente militar nas guerras europeias, Juan de Borjas. No entanto, não foi possível sua derrota ou subordinação, contra a qual a coroa espanhola decidiu optar por uma nova estratégia atingir o seu objectivo, movendo-se para uma segunda fase da conquista dos nasa, mas não com os militares e com os missionários.

A partir da Governadoria do Neiva, fundada em 1612 como auxiliar da audiência real de Santa $\mathrm{Fe}$, começou uma segunda fase na conquista dos nasa, não só por meios militares, mas também através de atividades missionárias. Missionários jesuítas vieram para fundar cidades e conquistar almas ao longo do caminho por Juan de Borjas ligando para Neiva com Popayan por Guanacas.

Em 1613 os jesuítas vim a missão em guanacas e os franciscanos de Neiva ganham influência Topa e Pedregal, ou na mesma região de guanacas. É muito importante salientar o significado político desta aventura da conquista do Paez porque tem muita importância nas relações entre Popayán e o Paeces. (FINDJI; ROJAS, 1985, p.34)

Mandou o missionário significa uma mudança na filosofia e prática dos espanhóis, desde a conquista para a colônia, já não procura destruí-los, como era o objetivo da fase que antecedeu a chegada dos missionários, tempo visa integrá-los e submetê-los à nova ordem, a colônia de sociedade envolvente. 
Com esta nova relação estratégia destina-se pelo menos atingir através dos territórios indígenas e para restaurar a comunicação entre o público real de Santa Fe e Quito, sede administrativa da conquista espanhola. A possibilidade de circular e obtenção de consentimento no uso de seus territórios, é o que se busca inicialmente através da ação dos missionários. Da mesma forma, os missionários procuraram atrair comunidades indígenas espalhadas para novas aldeias criadas a fim de torná-los mais acessíveis para os planos de trabalho e arrecadação de impostos. Tratando-os integrar na sociedade colonial para transformá-los em cristãos e "civilizado".

Mas os esforços dos missionários teria pouco sucesso e eles renunciaria a sua missão, depois de lutar durante 27 anos na região de Tierradentro, aposentando-se permanentemente em 1640 os jesuítas.

Os jesuítas evangelizaram o Paeces na sua breñas até 1640; A luta de zelo amoroso, de auto-sacrifício incomparável foi interrompida talvez devido à falta de trabalhadores, talvez por má vontade, por rebelde, nascido nos índios, pelo ódio de todos os elemento branco. Brigaram com os pais em um campo onde não se sabe qual era o maior perigo, se homens ou da natureza em si; rochas íngremes para chegar ao cabanas, assustadores desfiladeiros, rios invadeável que devem salvar pontes de bambu fraco empacotados com videiras; torrentes de traiçoeiros. (GONZALES, 1979, p. 58)

O missionário David Gonzalez (1979) em sua revisão histórica da nasa, citar o trabalho do padre jesuíta Manuel Rodríguez publicado em 1684, no qual ele reclama do espírito indomável de nasa e sua resistência a aceitar a religião católica, apesar do trabalho duro dos missionários por subjugá-los em suas crenças.

Os Paez são as pessoas mais rude e barba que eu acho que foi conhecido nas Índias. Pacificados e confiada a vários vizinhos de Popayán e saindo duas vezes por ano para servir seus mestres em suas sementeiras e colheitas de suas fazendas, nunca foram seus encomenderos aproximá-los a um único território ou minimizar fora dos povos, para resistir, especialmente. Que vem facilmente para ser capaz dos ministérios da nossa Santa religião para ser batizado, e pouco adultos são cristãos por sua grande grosseria, ao 
qual adicionar não frequentam o ensino com riso alto fazer zombaria do que é dito... o povo é o mais bárbaro e não é possível que a América descoberta em que um baseado pode duvidar se eram racionais. Sua inclinação mais conhecida é a lazer e a embriaguez... não se sabe que reconhecer qualquer divindade, sendo incapaz de atingir um senhor supremo e primeiro a causa de tudo... difícil de ensino por razões de multidões... Resistência das pessoas que vivem em aldeias, o que tornou difícil para juntos para torná-los a pregar, a rebelião de ódio concentrado pela amarga lembrança de brancos, odeio que você os fez tímido, tímido, zombando e deixando apenas o missionário que acreditavam que uma astúcia enviada para enganá-los. (Gonzáles, 1979, p. 59-60)

Aposentando-se os jesuítas de Tierradentro deixou aos cuidados da nasa o coadjutor de guambia, residente no lado ocidental da cordilheira central. Esta situação de instabilidade e redução considerável da população indígena, a nasa e a coroa espanhola decidiu temporariamente, acabar com os confrontos e dar uma gestão política para a situação assinando um acordo de paz, que eu me envolvo sendo "igual para igual". Acordos que foram compreendidos pelas comunidades, como as manifestações de paz e respeito pelos seus direitos; Enquanto os invasores levando-os como manifestações da apresentação para seu domínio e a partir deles, enfatizando seus abusos e da exploração "(BONILLA, 1979, P.335).

Dadas as dificuldades encontradas pela coroa espanhola para implementar o regime colonial e a redução demográfica e enfraquecimento da nasa que tornou impossível para eles manter que sua resistência militar à conquista no final do século XVII e início do século XVIII são mutuamente obrigados a reconhecer as suas autoridades, povos indígenas aceitam a autoridade espanhola do domínio colonial e a coroa espanhola a existência de chefes e suas chefias. O padrão de povoamento disperso da vila localizada a nasa e sua resistência constante a juntar-se a sociedade colonial em uma posição marginal da economia, uma vez que eles trabalharam nas minas, nem eram grandes agricultores, situação que iria beneficiá-los no período a iniciar, o período de resguardos. 


\subsection{Los resguardos y los cacicazgos coloniales}

Assim começou uma nova era política para caucanos nativos: do colonialismo. Forçado, eles tiveram que aceitar o pagamento de tributo. Mas eles eram politicamente conscientes de que sua qualidade de vencidos na guerra não quis dizer de qualquer forma, perder o direito sobre os territórios que foram ocupados, mesmo que era antes da guerra e ao rei. (BONILLA, 1979, P.337)

Como resultado a transição do período da invasão ou conquista para a administração colonial, foi criado o sistema dos guardas como parte de uma política que permitiu a coroa para ter mais controle sobre as populações indígenas.

Os resguardos são as unidades político-territoriais através das quais a coroa reconheceu a propriedade coletiva dos territórios indígenas e deu-lhes um certo grau de autonomia que lhes permitisse viver pacificamente em comunidades sedentárias.

Guarda terra título concedido a um Conselho composto por chieftain e suas autoridades locais ou principais. Direitos de terra foram administrados pelo Cacique e o cabildo, o território atribuído a produção agrícola para alimentar a população que vivia em sua jurisdição. Servindo os restos de mão de obra para as fazendas vizinhas (GONZALES, 1979, p. 50).

Estes territórios protegidos não foram definidos estritamente, freqüentemente incluíam as terras situadas num raio de uma milha, medido do centro do povoado. "As terras do abrigo diferiam de outras possessões no Império novo no fato de que não pode ser comprado ou vendido (1979 GONZALEZ, p.28)."

Dentro do abrigo, a terra foi subdividida em terras comunais, florestas, parcelas individuais e um centro urbano com a sua igreja. A concentração do sobrevivente indígenas dos povos a devastação demográfica que represento a conquista em assentamentos estáveis e centralizados "também deixou grandes extensões de terreno livre para o uso dos espanhóis" (COLMENARES, 1975, p. 226-227).

Embora o sistema colonial permitido um certo grau de política e autonomia territorial às comunidades indígenas também-los isolados da sociedade dominante para mantê-los como um 
remanescente de trabalho de fácil acesso, contra o declínio demográfico apresentado durante os colônia

O sistema de resguardos nasa representado um grupo marginal na economia e os interesses da elite regional que se preocupava mais com a preservação da mão de obra para suas fazendas para áspero por terra indígena. Muitos viram a formação da guarda como um meio de reduzir o que ele considerava uma ameaça indígena em assentamentos espanhóis. (FINDJI E ROJAS. 1985, P. 36).

Gera uma atenção especial o fato de que a nasa se apropriou desta instituição e transformálo para torná-lo a servir os interesses de defesa territorial, para consolidar, através dele, o poder das novas chefias, cuja autoridade é legitimado através de instituições espanholas e indígenas. O que fez a diferença com a forma que levou os guardas em outro lugar na Colômbia como Bogotá, desde guardas nasa não foram impostas pela coroa para as comunidades.

Mas surgiram através dos esforços dos próprios indígenas então foi reconhecida como proprietário e primeiro habitantes destes territórios.

Para escolher os resguardos os nasa esperavam defender sua autonomia territorial em terras que consideravam o direito próprio, se foi como resultado eles estão ocupados em tempos pré-colombianos ou instalaram neles durante a conquista. (RAPPAPORT, 2000, p. 77).

A estratégia dos guardas da nasa forma procurou assegurar o domínio político dos territórios que consideravam seu. Enquanto a guarda era uma instituição alienígena que os ajudou a alcançar seus objetivos.

Isto foi feito possível sob domínio colonial espanhol desde que a coroa estava disposta a reconhecer algum grau de autonomia política (fueros) que concedeu que esta lei respeitados acordos fiscais e, portanto, em última análise, reconhecer a autoridade do rei (Bonilla 1979:331).

Novas chefias que foram constituídas a partir da formação dos guardas seria muito diferentes das formas pré-colombiana do governo, como sua autoridade era exercida em um 
território contínuo, delimitada e o cacique tinha um permanente poder legitimado tanto interna como externamente.

Embora a coroa garantidas a autoridade política dos novos chefes, estes tinham que legitimar o seu poder dentro de suas próprias comunidades. Esta tarefa foi realizada em parte pelo poder de facto que lhes concedido os chefes de novos seus curadores; -Não devemos esquecer que os chefes eram parte ativa no censo de imposto diferentes que foram feitas durante o período colonial, como claramente aparece na XVII e documentos do século XVIII que aparecem como coletores de impostos para a coroa. (RAPPAPORT, 2000, p. 82).

Ao contrário a descentralização das chefias que precedeu o novo, estas foram muito mais centralizadas, pertencia a esta já não seria definido por lealdade ao chefe particular mas através a filiação a uma unidade política que era subordinada à coroa espanhola. O que lhe daria maior rigidez no que se refere o Regulamento dos seus membros, que incluía afluentes numeração regulares que impôs a obrigação de manter um vínculo de lealdade que asseguram um fluxo regular de tributos para a coroa. Assim, no início da nação do século XVIII que NASA consistia de quatro guardas sob a autoridade dos três chefes e unidades políticas menores que foram vinculados a estes quatro por vínculo matrimonial e o favoritismo. 


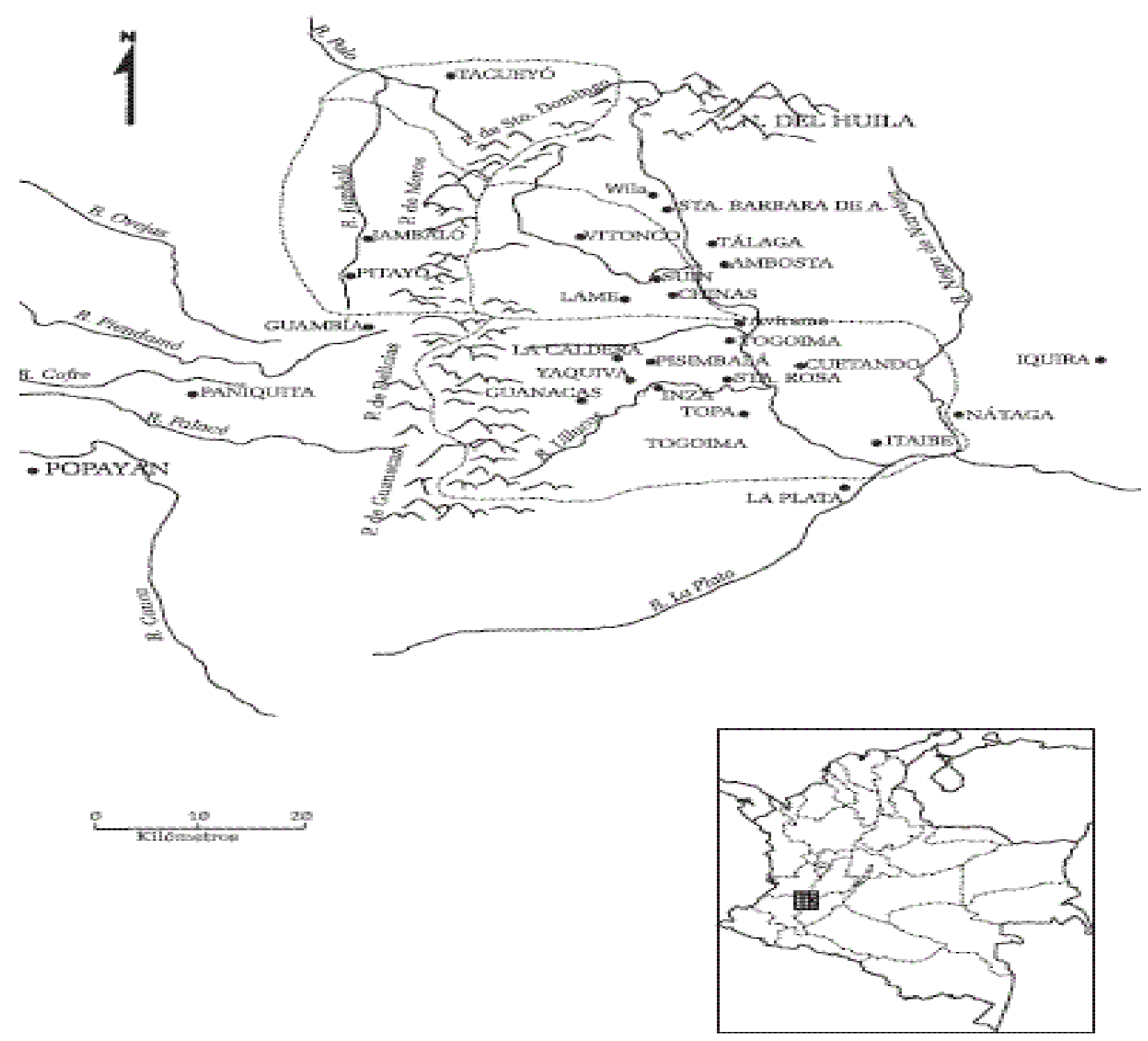

Figura 3 Cacicazgos nasa durante la colonia ${ }^{4}$.

Do ponto de vista da administração colonial espanhola a legitimidade destas unidades políticas traga a força dos títulos de terra que eram os guardas e que concedeu sua administração para os próprios chefes, "cuja autoridade e nobreza eram, além disso, conferiu da Europa" (RAPPAPORT, 2000, p. 80). A unificação do povo nasa foi feita a partir da vinculação das diversas unidades pequenas, autônomas internamente, relacionados através de seus respectivos chefes. Durante a época colonial da nasa que legitimaram a sua autoridade e defenderam seu território das guardas concedeu títulos, reforçar o poder político desta figura da administração colonial, que lhe

\footnotetext{
${ }^{4}$ Tomado de RAPPAPORT, 2000, p.79.
} 
deu um certo grau de autonomia. Dando continuidade à defesa do seu território, desta vez não militar, mas a nível político.

O fenômeno dos chamados novos chefes tem profundas implicações, porque os guardas, então, não foram criados de acordo com os imperativos económicos da coroa, mas diretamente foram reivindicados pelos povos indígenas, para fortalecer um modelo regional de autoridade e uma claramente diferenciada do território não-indígenas. Para o primeiro chefes de tempo foram governantes não só militares e civis, e conquistou também é pequenos, mas significativos os níveis de autonomia (GOMEZ; RUIZ, p.34 1997).

O regime colonial que se consolida no início do século XVIII, regida pela figura política e administrativa da encomenda gerado em deslocamento a nasa e vários agrupamentos que responde à segregação entre colonizadores e colonizados.

Em certo sentido a tradição de dispersos liquidação do Paez e outras tribos aliados permitidos resistência à colônia para adotar esse padrão de dispersão. Contornar os espanhóis não quis dizer, então, para o Paeces covardia e abandono do território, mas a reprodução de um modelo de população e a economia. (FINDJI E ROJAS. 1985, P. 37)

Obviamente, esta situação é um obstáculo para a política colonial dos espanhóis e, em seguida, as recomendações emitidas a partir da coroa espanhola para preencher ou reduzir stable os assentamentos Paeces espalhados. No arquivo central Cauca são documentos que registram a Constituição dos primeiros assentamentos estáveis dos índios Paeces de 1719.

No entanto, durante o século XVIII permanece a preocupação da coroa espanhola para aumentar, controlar e organizar o assentamento de sua colônia. Os cronistas descrevem esses assentamentos permanentes "vilas de índios" como referindo-se a um grupo de casas para aqueles que vêm a parte do povo indígena de uma comunidade, quando eles têm que cumprir com a obrigação de pagar ou receber instruções de doctrinero o padre, principalmente; Mas não é um site de vida permanente.

O conjunto de liquidação ou "cidade dos índios" como espaço delimitado, descontínuo e usado no fornecerá a abordagem e a necessária relação de coexistência entre o Paeces e seus colonos. Permitindo-lhes conhecê-los e copiá-los de conhecimentos úteis, mantendo, ao mesmo tempo um mínimo de submissão graças a sua dispersão. 
"É por isso que os historiadores reconhecem que o Paeces conseguiram escapar para a sujeição permanente desta vez." (FINDJI E ROJAS. 1985, P. 38) Esta integração semi e dispersão tinham efeitos negativos sobre as pessoas da nasa, porque mesmo que eu consegui impedir o envio completo para os conquistadores, eu também impossibilito uma concentração de forças próprias e uma acumulação dos produtos do trabalho. Neste período, a população indígena desta região sofre um processo de transformação social, que seria representada naqueles que foram chamados como novas chefias.

A geração dos índios que enfrentaria a colônia no século XVIII nasceu quando os restos da realidade pré-colombiana desapareceram completamente, impondo a necessidade de coexistir com os conquistadores. Entre estas mudanças é que alguns povos indígenas aprenderam a falar espanhol, sendo intermediários entre espanhóis e índios, situação que não existia antes na conquista e mostrando as mudanças sociais que começaram a aparecer entre os povos indígenas. Estes novos líderes conduzirá a relação entre conquistadores e de nativos, enfrentando o problema de como encontrar uma autonomia dos encomenderos, que começaram a se opor a nova política da coroa espanhola.

Os novos chefes da nasa vão aproveitar esta contradição entre curadores e coroa para o desenvolvimento da sua própria política. Recorrer a fórmulas legais que lhes permitiam fazer uso das duas instituiçõos endossado o um e outro, estabelecido em outras partes do Império, anos atrás. Estas são a chefia e o abrigo. Por necessidade os colonos terão de aceitar este processo jurídico e político de demarcação de territórios indígenas que estariam sob a autoridade de chefias a nova. A primeira solicitação para alinderamiento dos territórios indígenas na encosta ocidental da cordilheira central são trazidos pelo chefe da tubulação do órgão Cactus, don Jacinto de Moscay para a Real audiência de Quito em 1696.Esta aplicativo baseia-se em vários pontos:

Primeiro que embora "é verdade que ninguém nos intranquiliza ou interrompe os nossos direitos," é o seu dever de assegurar as terras dos índios para sua morte não são invadidas por intrusos. Em segundo lugar, Considerando que é o rei que "é dar-lhes terras na propriedade e conceder escritas, dar-lhes e como um cacique de títulos, o que me pertence como tal", freqüenta o chefe legítimo então essa dotação é seu direito. Em terceiro lugar, solicita "que me conceda a faculdade se é necessário dividir a minha 
terra de índios para cada cidade, como eu bastante regular parece que cada um deles sabe que se aplica a você". Mas ele argumenta fortemente que deve ser claro que embora as terras atribuídas por pessoas não ser conhecido outro chefe que ele e seus legítimos sucessores: e nomeia como seu sucessor para Tama de Don Juan da estrela, seu sobrinho. (Citado por FINDJI e ROJAS. 1985, p. 41).

Dois anos da morte do cacique Moscay volta da Espanha o pedido que ele tinha apresentado, tornando-se presentes na platéia real de Quito o novo cacique Don Juan Tama star solicitando que você será entregue a documentação e solicitou o reconhecimento. Após vários bloqueios 8 de março de 1700 se rende ao Juan Tama da estrela o título reconhecendo índios - jambar, Quichaya, Pueblo Nuevo e Caldono - como uma arma exclusiva dos territórios que eles habitavam. Este título real dado ao chefe da autoridade para distribuir e alocar terra de povos diferentes, mas estas permanecerão subordinado a ele. Reconhecendo a existência de um direito preferencial de índio na posse das terras da América. Neste mesmo cacique ano Quilo e compadre básica de Juan Tama da estrela perguntada para a platéia real de Quito que é concedido a pessoas das aldeias de Toribío, Tacueyó e San Francisco, o território que habitam.

Assegurar no seu pedido que essas terras não sejam livres de "Propriedade", e que não foi reconhecido o outro proprietário do que os chefes, mas querendo fazer a posse dos povos indígenas no futuro atende o rei como autoridade competente para conceder títulos ou papéis que reconhece a posse de seu território. Antecipando-se ao longo do tempo que os colonos planeiam para tomar o seu território. Pedindo que o alinhamento de suas terras é feito por um Comissário da audiência real. Quilo e aplicativo básico destaca-se o princípio jurídico de direito indígena ancestral que evoca.

Eu acho que só a vossa Majestade, tem o direito de ceder terras para pessoas brancas e isto sem prejuízo para os índios tributário porque mais temos direitos e preferência, porque como nós dependemos americano legítimo e não somos vizinhos de outros lugares estranhos, parece-me atende muito bem para mais de possuir um. Por que nos preferimos nos olhando, primeiro como um submisso afluentes e em segundo lugar com justiça, como dignos de credores a terra do que os nossos antepassados e aqueles 
que vêm pela nossa origem e princípios. ( $\mathrm{O}$ título real das aldeias de Toribío, Tacueyó e San Francisco. Citado por FINDJI e ROJAS. 1985, p. 43)

A finalidade da Tama e Quilo e músicos assegurar o território dos seus povos foi bem sucedido e consolidou seu poder político como a principal autoridade. O último tinha pedido para fazer a demarcação do seu território, as autoridades coloniais e assim foi: um representante da corte real viajou expressamente Quito até Tacueyó, fez aquele alinderamiento. (FINDJI E ROJAS. 1985, P. 43).

Mas aos Juan Tama chefe principal da tubulação do órgão cacto é concedida a faculdade do mesmo ser que guarda os loteamentos dos diferentes povos sob a sua autoridade, como seria mais tarde. Há 40 anos, um processo de delimitação do território dá nasa pela coroa espanhola. Indo diretamente à autoridade real, sendo feita para reconhecer os novos chefes como governantes das suas populações e territórios, deixando-o para passar para os conflitos que possam surgir com os senhorios e encomenderos. Submetendo ao soberano, como sujeitos de Espanha, mas começálo para reconhecê-los como autoridades de seus próprios povos e territórios.

Ou seja, aquele chefes reconhecem a realidade da derrota e o domínio do rei, mas ele claramente expresso que para o Paeces continua e continuará a governar um direito preferencial, inalienável e superior ao monarca espanhol: isso dá-lhes ser "legítimo americano e não vêm de lugares estranhos". Uma expressão que é transformada em uma proclamação política de defesa da autonomia indígena, cujo eco continuará promovendo caucanos ação indígena até aos nossos dias. (BONILLA, 1979, P.338)

Descrição geral que é feita dos territórios concedidos para os grandes chefes de cacto de tubulação do órgão e Tacueyo, corresponde a "terras naquela época tinham que ser muito difícil ir pela vegetação que cobriu-nos, mas, obviamente, os separava as terras que os espanhóis queriam." (FINDJI E ROJAS. 1985, P. 44)

Mas este prêmio tem um caráter político, para reivindicar o reconhecimento da autoridade indígena baseada no fato de que eles viviam e governaram seu território antes da chegada dos espanhóis. Abrigar títulos estabelecidos "numa base territorial e política para as comunidades e 
também forneceu uma interpretação nasa das relações interétnicas e o surgimento de uma nova autoridade política." (RAPPAPORT, 2000, P. 48).

Como resultado a certificação e o estabelecimento de salvaguardas, a nasa conseguiu a posse de grandes extensões de terra sob o preceito legal de ser os primeiros habitantes destes territórios. Bem como o direito de distribuir o território como eles consideram isso. Esta aceitação e a adaptação para a colônia, não digo uma claudicação à sua organização e costumes. Desde que eles aceitaram a instituição do cabildo em guardas como uma entidade responsável pela recolhendo tributo e mantendo relações com a estrutura administrativa colonial espanhol. Mas manteve suas próprias autoridades responsáveis para a regulamentação das relações internas, administrar a justiça e assegurar a preservação das tradições culturais.

Alcançado pelo reconhecimento político de novos chefes coloniais e delimitação das salvaguardas, nomeadamente prática social não foram aceites pelos curadores e colonos que se opunham, por todos os meios, estas novas disposições da coroa.

Durante o século XVIII foram constante litígio jurídico empreendido entre chefes e proprietários ou funcionários da coroa buscando expropriar os índios da terra produtiva, confinálos a infrutífera parada inabitável, fingindo reduzir os territórios indígenas para partes da região que não servem a manutenção humana. Para os herdeiros dos encomenderos, mineiros e novos proprietários, ou seja, a classe dominante na região, os índios não têm direitos, pelo contrário, deve desaparecer da face da terra.

Esta situação de conflito para persistir a ignorância dos direitos concedidos aos povos indígenas, é provavelmente a razão principal da participação ativa da nasa nas lutas para o Independência. A, apesar da falta de direitos indígenas e reivindicações de expropriação da classe dominante da região de Cauca, a delimitação das terras de recepção, no âmbito geral de reconhecimento das chefias indígenas no século XVIII Eu represento a base material da recuperação demográfica e física da nasa, em comparação com a situação em que eram há um século atrás. Ou pelo menos assim podemos deduzir da sua grande participação nas guerras de independência do início do século XIX. No final da colônia espanhola, a nasa conseguiu sobreviver como povo, mantendo grande parte de sua organização social, relações sociais de produção, visão de mundo e, o que é mais importante para sua identidade, território e lealdade a ele como pessoas. 


\subsection{A República e a configuração da nação Estado colombiano}

A ruptura com a metrópole espanhola quer dizer um longo trânsito orientado para definir novas formas de governo e divisões administrativas. Para desaparecer o poder unificador que representa a colônia através de várias formas de exploração econômica e subordinação política que agenciava o aparelho do governo espanhol, através da sua política colonial. Apresentando um vácuo de poder do qual teria que ser reconfigurada territorialidade e política da nova granada que dará origem a uma nação unificada dentro da nova República. Processo que seria de pós-colonial condições internas e os elementos existentes no contexto internacional. No final das guerras de "independência", a nova elite dominante não tem o controle do território da nova República e é dividido em frações que rosto em 9 guerras civis durante o século XIX, para atingir cada um iria impor seu projeto político.

Logo após a guerra de emancipação é iniciada, então, os conflitos internos do acórdão nativo classes para preencher o vácuo de poder, vai dominar o novo estado. Luta feroz com base nas diferenças de interesses, que devem ser estendidas ao longo do século XIX e cujos efeitos imediatos foram fraco e mudança de estado. Estado que só seria fortalecer e unificar uma vez que as classes dominantes enfrentaram tinha alcançado um acordo sobre a natureza do que. (BONILLA, 1979, P.330).

Governando elites pós-colonial seria dividido em dois sectores, por um lado os crioulos ligados ao comércio internacional manipulado pelo imperialismo inglês e por outro lado, a aristocracia conservadora que procurou manter a ordem social provenientes da colônia em regiões que dominou, como foi o caso do departamento de Cauca. A divergência política destes dois sectores baseado nas características da nova ordem política, procurando aqueles criar um centralista de estado e o outro um estado federalista. A nasa a participar massivamente nas guerras de "independência" e confrontos civis subseqüentes, assumindo-os como uma continuação de suas lutas para defender seu território e cultura.

"Desde que estiveram envolvidos nestes, com a ilusão de que uma vez alcançado vitória reconhece autoridade, cultura e território." Política do Paeces participar de confrontos militares foi apresentar dentro das lutas em curso assim que eles sentiram que iam derrotar o inimigo interno, 
abrindo perspectivas melhores para o seu povo "(BONILLA, 1979, P.346). Mas previstas, no pouco tempo de terminado o confronto, o novo governo rapidamente desapontaria as esperanças da nasa.

Desde imediatamente promovidas leis e atos administrativos, buscando a liquidação de diferentes dos guardas República como unidade territorial política e administrativa. Inauguração para os índios do que o inimigo era não só o colonizador estrangeiro, mas era o mesmo interior da Colômbia.

A transição da colônia para a República através do chamado processo de independência foi realizada sob o paradigma liberal da modernidade, com base na configuração de um novo sujeito social que seria cidadão livre. Enfrentando os povos indígenas de forma diferente. O novo estado adotado instituições liberais e constitucionais, bem como um modelo de nação culturalmente homogêneo impostas coercitivamente em contextos interculturais e multiétnicas. Perpetuando os princípios das políticas de retenção e controle que procurou integrar ou assimilar povos indígenas em nacionais pela tutela do Estado ou da sociedade eclesial sob as idéias de "civilização" e "Evangelismo".

Das instalações da unidade territorial e da homogeneidade cultural estado-nação colombiana considerarem necessário para pôr um fim à diversidade cultural e as culturas indígenas, negras e europeias em uma mistura homogênea que produziria a identidade nacional se fundem. "Esperando o efeito genético do branco é sobrepusera para outro em um processo de miscigenação conhecido como" branqueamento." (RAMOS, 2002, p. 10)

No republicano de novo ordem que o estado unitário foi que a sociedade era uma amálgama de culturas representadas em uma identidade uniforme, embora no seio dos conflitos sociais campo subyacieran forte interétnica.

Os problemas encontrados pela República Nova com a tributação indiana mostra como ideológica "igualdade dos indivíduos" exigiu a realidade indígena. Além disso, esse discurso igualitária e libertária irão justificar a aniquilação de todos os indianos na medida em que ele encarna a colônia de cão. Porque durante a época colonial, os índios eram diferentes e inferiores, mas este "desigualdade" traduzido para o reconhecimento da discriminação implicado de sua existência como discriminação; A República em vez disso pretende abolir a desigualdade suprimindo 
diferentes e inferiores. Na representação da realidade social e política da América não couber a visão das duas repúblicas, já não se encaixa a visão dos povos de índios frontais ou paralelos para as cidades ou vilas espanholas. A eliminação da realidade administrativa e a representação das cidades indígenas mundo passaram praticamente despercebidos na literatura histórica colombiana, mas parece muito importantes enfatizar porque está paralelo a supressão de outro elemento da organização sóciopolítica colonial e a eliminação das chefias. (FINDJI E ROJAS. 1985, P. 67).

A mudança de status político que gerou a configuração da nação colombiana não alterou radicalmente as relações sociais que precedeu, são seguidos com base em um colonialismo de poder com base em raça, classe e gênero hierarquias (ver QUIJANO 2005).

Para os povos indígenas nos processos de construção da nação latinoamericana, quero dizer que o início de um ataque agudo e violento contra o qual baseou-se em um andaime ideológica construída pelas elites nacionalistas que, de sua posição etnocêntrica, defendida pela formação de uma população nacional unificada em torno dos valores culturais próximos do legado Europeu. Os idiomas espanhol e Português, a religião católica e políticas de integração cultural e raça de fusão, quando não é grande o extermínio físico de populações indígenas. (GARCES LOPEZ, 2002, p. 97).

As implicações que os povos indígenas tiveram a constituição do estado-nação estarão relacionadas ao fato de que durante a época colonial, a coroa espanhola reconheceu a diversidade social e cultural existentes nos subordinados, internalizando-os por causa disto, mas dando-lhes um certo grau de autonomia nas suas relações com o aparelho de governo colonial, ou fueros fornecido pagam tributo em reconhecimento da autoridade real. Então, o assentamento não significa a eliminação de todos os povos indígenas em Nova granada.

Em contraste com esta situação, o novo estado-nação colombiano teria um manifesto interesse eliminar legado e diversidade cultural que representa os povos indígenas, desde a afirmarse como uma entidade política independente deve pôr um fim a todos os direitos, sistemas 
organizacionais ou de instituições da colônia, trabalho vital para formar uma nova sociedade. Os povos indígenas representam o passado colonial, o novo estado de crioulo concebe a obrigação de apagá-los. Desde que o interesse dos líderes da novos era o molde a população dos territórios liberados do colonialismo espanhol para os requisitos do novo imperialismo inglês perceberam isso como um modelo para o progresso continuar.

Em uma frase, evitar a todo custo para dentro deste território, ainda maciçamente habitado por povos indígenas e seus descendentes ainda influenciados, retornar para continuar o segmento quebrado de uma forma de desenvolvimento. E para tal tarefa, transformam o melhor dos seus esforços através da importação de modelos económicos, educacionais e políticos de Inglaterra para garantir seu objetivo. (BONILLA, 1979, P.331)

Neste sentido, os povos indígenas foram um obstáculo para o desenvolvimento da República, desde que eles viviam em muitos dos territórios que é cobiçado pela nova classe dominante. Tornar-se inaceitável a existência de guardas, terras de comunidade regidas pelas próprias autoridades onde há um elevado sentido de coletividade que permitiu manter as práticas e costumes de um passado que você deseja excluir.

A persistência das terras coletivas, as autoridades que não sejam os da República e um elevado sentido de coletividade, argumentou com propriedade privada e do individualismo que precisava de capitalismo em expansão no cenário internacional e a nova unidade, no local.

Daí que a negação dos povos indígenas um significado político fundamental, constituiu-se uma necessidade política em conformidade com os interesses dos novos mestres do estado. Não é de surpreender, então, que acaba de ganhar independência tinha começado um novo tipo de guerra contra as comunidades indígenas. Uma guerra que estava à frente do golpe de leis ordenando a abolição dos guardas e sua dissolução. Leis que, devido a fraqueza do estado nascente, e a resistência das comunidades locais não eram muito eficaz. (BONILLA, 1979, P.332)

Esta guerra travada contra as autoridades, instituições e povos indígenas baseou-se em razão da terminando o obscurantismo das instituições coloniais e introduzir os índios para a nova ordem em vigor. Mas para esta negação jurídica dos direitos dos povos indígenas são também empunhar 
razões democráticas, como a correspondência dos índios com outros cidadãos, embora na medida do possível, todos os obstáculos que impediram fazem-los participantes do progresso. Dependendo do sector de crioulo liderança que está localizada na estrutura administrativa das políticas relativas aos povos indígenas estado teve algumas mudanças. Quando os comerciantes dominavam financiadores representados no partido liberal, as pressões pela dissolução dos guardas e o loteamento de terras indígenas era maior.

Por outro lado, quando governantes eram os militares-políticos proprietários no partido conservador que tinham nas insurreições do trabalho indígena e seus militares usado para aceitar a sua continuidade, aparentemente promover protecionistas leis. Como aconteceu no Gran de Cauca, que representa metade do país até então (BONILLA, 1979, P.333).

Um documento datado de 1825, no qual o governo de Popayan recebe uma resposta do Secretário de estado para uma consulta sobre autoridades tradicionais indígenas, salientou que "O executivo considerado extintos chefes hereditários títulos" (national archives de volume único de Colômbia, Bogotá-República de índios, Folio 467r.). Ok, a concepção geral dos governantes da República, os índios são iguais aos outros cidadãos e, portanto, não devem ser uma forma de organização política diferente do resto do país. Mas a lei 90 de 1859 soberano estado de Cauca, que está disponível na Gazeta de Cauca (ano $3 \mathrm{n}^{\circ}$ 74) e que é a mais elaborada e a mais desenvolvida da lei indígena do século XIX, podemos ler:

Em todos os lugares onde um viés dos indígenas dos povos é estabelecida, haverá um pequeno conselho, nomeado por estas, o período de duração do presente capítulo deve ser de um ano, contado a partir de primeiro de janeiro a 31 de dezembro. Para tomar posse de seus cargos não precisa de membros do cabildo de outra formalidade do que o de ser reconhecido pelo preconceito, contra o Conselho cessante. (Diário do Cauca (ano 3 n ${ }^{\circ} 74$ )

Durante o século XIX os guardas e as autoridades tradicionais do cabildo sofrerá uma miríade de transformações em relação ao século anterior durante a colônia, para ser pulverizadorsecos e reduzidos a uma unidade social mínima. A nova legislação republicana desmonta a política da nasa territórios coloniais, a reconhecer apenas um pequeno conselho em cada viés, que servem como intermediário entre as comunidades indígenas isoladas e autoridades governamentais. Este 
novo regulamento é uma mudança radical de territorialidade e a autoridade dos povos indígenas em relação a colônia, durante um guarda podem corresponder a um viés, mas também havia guardas envolvidos em várias parcelas e acima de tudo, havia vários guardas sob o comando de um único chefe supremo. Preconceito é uma unidade territorial menor, que foi integrada a uma unidade maior que foi do recebimento de uma chefia.

Reduza a autoridade e o território indígena como um limpa de unidade social básica qualquer outra forma de integração ou de organização política do povo da nasa, que é a maior conquista dos chefes supremos durante o século XVIII, como é o caso com Juan Tama. "Há a importância política da transformação executada pela República para impedir a existência de chefias. "Pensei que o republicano está completamente ciente o efeito político." (FINDJI E ROJAS. 1985, P. 69).

Apesar da fragmentação da autoridade e territorialidade da nasa sendo reduzidos a pequenas unidades de cabildos separaram umas das outras e trancou a acenda de Murua permanece uma intensa rede de relações entre os diferentes grupos, integrando as unidades territoriais das duas encostas da cordilheira central do tubo de Tierradentro-órgão interno do eixo Toribío-cactoTacueyó.

Durante o século XIX uma série de leis contra os guardas que foram concebidos como medidas temporárias que permitem o desenvolvimento econômico baseado na propriedade privada, foram emitidos, portanto, sempre foram orientadas para dividir e pagar os territórios indígenas. Como por exemplo as reformas liberais dos anos 1950 promovendo a generalização da propriedade privada, desde que esta era uma condição primária para a participação política de cidadãos da República" proprietárias" referidos em algumas das 6 Constituições do século XIX.

No entanto, este proprietário cidadãos República não é suportada na existência de chefes com "posse da terra", ou seja, com parcial de seu comando. Ao invés de fornecer índios individuais em benefício da "propriedade privada sem a qual não há nenhum progresso econômico", a República tem que privar os líderes de suas chief tainships porque eles envolvem o domínio territorial, ou seja, o controle de um lugar e um povo. Só sobre essa base, será capaz de justificar a luta social específica através 
do qual o novo nacional venha a tira os nativos de suas terras (FINDJI E ROJAS. 1985, P. 69).

Com o triunfo do partido liberal no século XIX as terras do Estado colombiano seria alterada e aceitaria uma União de Estados independentes agrícolas, onde o soberano estado de Cauca seria um dos maiores geograficamente. Desde que o governo liberal estava interessado os comerciantes e exportadores de produtos agrícolas, começa uma ofensiva agressiva para expropriar os territórios indígenas coletivos e apresentá-los no mercado imobiliário, o que permitiria a sua exploração comercial através da hacienda de terraje (ver Bergquist, 1978; Triana 1985). Durante o século XIX as terras dos antigos guardas começaram a passar a mão de proprietários que fulminou de truques legais ou por meio de usurpação violenta. Os senhorios deram as indígenas expropriadas pequenas parcelas de terra tão lá suas casas e culturas tem partido, não poderia plantar qualquer atividade agrícola permanente.

A figura desta parcela era o contrato de arrendamento, ou seja, proprietário de terras alugadas uma parcela da mesma terra que eles tinha de expropriação indígena, mas como eles não têm qualquer rendimento, eles foram forçados a pagar no trabalho livre para as finanças, homens na atividade agrícola ou pecuária e mulheres como empregados na casa do padrão. O terraje foi uma relação de caráter feudal, servil, que é obrigada para povos indígenas, a ser pago com trabalho livre, o direito de viver e desfrutar de um pequeno lote localizado em fazendas incorporou os territórios dos antigos guardas que estavam ele usurpou seus proprietários ancestrais por proprietários durante a República. Fazenda de terraje é que estrutura com base em uma dominação política e exploração econômica.

A fazenda de terraje impõe uma nova territorialidade. Requer o terrajeros para trabalhar, para viver, para mover cada um da parte estreita. Cada uma das fazendas, torna-se território - "jurisdição" - controlada pelo proprietário; Quem dá permissão para tocar aqui ou ali, que dá permissão para ter ou não ter animais. A força de trabalho disponível das famílias é gravado trabalho gratuitamente obrigatório que deve fornecê-lo com o terrajeros e suas famílias. Há evidências de vendas de títulos do tesouro, em parte ou na totalidade, que fizeram com terrajeros incluído; ou é a divisão da terrajeros ocorreu quando houve a divisão das terras, 
enfraquecer os laços internos e até o sistema de relações de parentesco (FINDJI; ROJAS, 1985, p. 92).

Desta forma, durante o século XIX, é configurar uma nova territorialidade, ou seja, uma nova organização do espaço e das relações sociais. Esta configuração da República em antigos territórios coloniais, poderia ser feito dos confrontos militares e atividades económicas, que respondeu à dinâmica internacional e às condições da sociedade pós colonial. Com o declínio na extração de ouro durante a segunda metade do século XIX, que a ligação da República para o mercado mundial é realizada através das exportações de produtos agrícolas da tinha uma grande demanda no mercado internacional, entre os quais se destaca a máquina. Sendo o departamento de Cauca e territórios indígenas em anexo para as fazendas de Murua que apresentou maior produção.

No final de 1870 uma prolongada crise na economia de exportação e fortes divisões no partido liberal, levou a uma crescente ansiedade política e social. Na guerra civil de 1885, que resultou na derrota dos Liberais (radicais), conservadores em aliança com os liberais independentes (moderada) conseguiu consolidar o poder em iniciou um programa de uma profunda reforma política (VAN DE SANDT, 2010, p.66).

A nova constituição de 1886 abandonou o federalismo e estabeleceu um estado unitário com um governo fortemente centralizado que implementar reformas políticas com base em medidas econômicas abertamente Antiliberalismo e uma restauração completa da aliança entre a Igreja e o estado, que se realizou em concordata de 1887 (ver SAFFORD; PALÁCIOS, 2002)

Para temporariamente, acabar com a divergência entre as classes dominantes e consolidar o estado durante o período conhecido como a regeneração (1880-1890) iria emitir novas medidas relativas aos povos indígenas. O que significava uma mudança na política dos indígenas, emitiu a lei 89 de 1890: "por que ele determina a maneira como eles devem governar selvagens que são reduzidas a vida civilizada" (castelo-CÁRDENAS 1987, P. 161).

Os regeneradores para ver que com as medidas tomadas em governos anteriores não conseguiu remover os povos indígenas e a sua organização, decidida ir para uma nova forma de ação, e através de lei 89 de 1890 reconheceram que não toda a população pertencia a sociedade colombiana, mas havia as comunidades indígenas para que o nome selvagens que viviam em abrigos. Aparecendo uma diferenciação entre a nacionalidade colombiana e estas nacionalidades 
indianas deve ser reduzido a vida civilizada. Para alcançar tal objetivo, foi assinado acordo com missões do Vaticano, dando à Igreja Católica, a tarefa de reduzir a vida indígena civilizada através da evangelização. 80 da lei de 1890 reconheceu recibo índios o direito de respeitar seus próprios conselhos, mas limitado-los de várias maneiras. Impondo-lhes a qualidade de menores como um sinal de sua plena integração à nação colombiana e é definido um prazo de 50 anos que Terminarão sua existência comunal.

Estas disposições demonstram a conotação política de medidas, os povos indígenas não são colombianos, mas devem tornar-se ele. E para isso eles terão que desistir de ter autonomia, território, línguas e culturas. E isto a qualquer preço: pôr do sol dissolução violenta, legal de suas comunidades ou reservas, missionário da penetração ou integração capitalista desenfreada. Esta é a política do estado nacional colombiano no final do século XIX (BONILLA, 1979, P.334).

Depois de concluído em 1902, o último grande confronto civil conhecida como a guerra dos mil dias e começou no final do século XIX, começa uma ofensiva pela expansão da fronteira agrícola com uma política nacional de assentamento, o que significaria a continuação do processo de expropriação do coletivo dos territórios indígenas e a remoção dos resguardos.

A convergência dos esforços da SRS pastores e missionários com a política do governo conservador neste aspecto é um dos elementos que definem a realidade do território republicano orientada no departamento de Cauca, como em muitas outras regiões do país (FINDJI E VERMELHO 1985, VOLTADA).

No alvorecer do século XX, o governo colombiano emite 55 lei de 1905, que foi mais uma vez, a separação dos guardas e a assimilação das culturas indígenas para a identidade da sociedade nacional no lugar de subordinação a eles. Lei 55 de 29 de abril de 1905, ele ordenou a dissolução das guardas como territórios indígenas coletivos e lhes deu a municípios localizados dentro da sua jurisdição.

O que, na prática, foi não mais do que dar passagem livre para os grandes proprietários de terras, então eles invadem mais ativamente guardas restantes. Tarefa para que vá incluindo os antigos aristocratas-soldados, 
que já não precisava das massas indígenas como soldados para suas guerras (BONILLA, 1979, P.350).

Contra estas medidas não esperava a reação da nasa, que através de queixas, memoriais, demandas e outras formas de pressões que buscou foi deposto o 190555 do ato. No entanto, essas ações teria pouco sucesso porque ele não só as leis eram contra, mas as classes dominantes após um século de confrontos civis foram finalmente unificadas e reforçou o estatuto.

Diante desta situação, a nasa iria começar a desenvolver um novo repertório de mobilização que impede a destruição da sua cultura e a perda completa de seus territórios ancestrais. Começando uma nova fase na luta política do povo nasa que se estenderia por todo o século XX e as primeiras décadas do século XXI.

No âmbito das transformações rápidas e profundas que poderia modificar a estrutura de social e económica do país, a nasa seria integrado para as novas classes sociais que começaram a se organizar em sindicatos, ligas, coordenadores e partes para defender seus interesses. Na década de 1910-1920, os departamentos de Cauca, Huila, Tolima e balançou pela mobilização indígena liderada por Manuel Quintin Lame, terrajero indiano que, depois de participar no último confronto civil grande do século XIX, levaria as pessoas nasa como professor e profeta de uma doutrina que afirma principalmente terra, liberdade e a alma de sua corrida para tentar reunir e tornar eficaz os direitos dos dispersos massa indígena do velho chief tainships, desde o planalto de Popayán de Tierradentro.

Manuel Quintín Lame, terrajero Páez; atacadista em cavalos nas proximidades de Popayán. Não era membro de qualquer parcialidade de abrigo ou autoridade tradicional indígena exercido. Por outro lado, recrutado individualmente, foi a ordenança do General Carlos Albán, que o acompanhou em suas aventuras por Nariño v Panamá durante a guerra de 1000 dias, experiências que lhe permitiu ver o mundo. Aprenda a ler e assistir de perto o comportamento das forças indígenas do Capitão Lawrence no istmo. Não é surpreendente, então, ao voltar da guerra, pondo em causa não é tanto a legitimidade ou conveniência dos regimes partidários, tais como a legalidade da sua situação de terrajero, o destino do seu povo para a regra "branco", como disse, e cheio de desconforto em 
relação de Cauca sociedade pelos meios de comunicação tanto os explorados e oprimidos (FINDJI E ROJAS. 1985, P. 76).

Iniciando seu trabalho de insurgência entre conselhos e terrajeros, tentando modificar a situação dos povos indígenas na sociedade nacional, com base no fato de que os povos indígenas são os verdadeiros donos da terra, inalienável direito proclamados há dois séculos pela nasa chefe supremo John Tama da plataforma Estrella. Sua luta baseou-se na defesa do viés indígena e rejeição das leis da extinção dos resguardos a consolidação do cabildo indígena como um centro de autoridade e base da própria organização, a rejeição e a condenação da discriminação a que os povos indígenas, libertação do terrajeros através da negação de pagamento terraje ou qualquer outro imposto, a recuperação de terra usurpada por proprietários e ignorância de todos os títulos que não são baseados em cartões reais estão sujeitos (Ver QUINTIN LAME, 1975).

No entanto, ele não só propõe um programa político

sino un resurgimiento espiritual que de fuerza para hacer valer sus derechos pisoteados; es acudir a la memoria colectiva para despertar la ambición de volver a ser libres y vivir holgadamente, como sus antepasados: es usar la acumulación de su experiencia como oprimidos, de sobrevivir en el infortunio; es volver a creer en una sabiduría y una ciencia de la naturaleza a la que están ligados, y que le son negados a los blancos. Elementos todos con los que alimenta una nueva $\mathrm{Fe}$, una conciencia militante que les permita triunfar (FINDJI Y ROJAS 1985, P. 76).

A revolta liderada por Manuel Quintin Lame foi reprimida e o aprisionado em várias ocasiões. No entanto, nunca desista em sua luta para a defesa dos direitos dos povos indígenas. A mobilização dos indígena início do século XX, revela a existência de uma capacidade interna na nasa que visam restaurar a unidade, continuar o processo de unificação da interna, reafirmamos o ser e direitos indígenas contra a ofensiva da sociedade nacional, o que quer que eles eliminam física e culturalmente. O programa político proposto por Manuel Quintín Lame seria retomado depois de 60 anos por indígenas do departamento de Cauca que cobrem a primeira organização indígena da Colômbia, o Conselho Regional indígena de Cauca. 


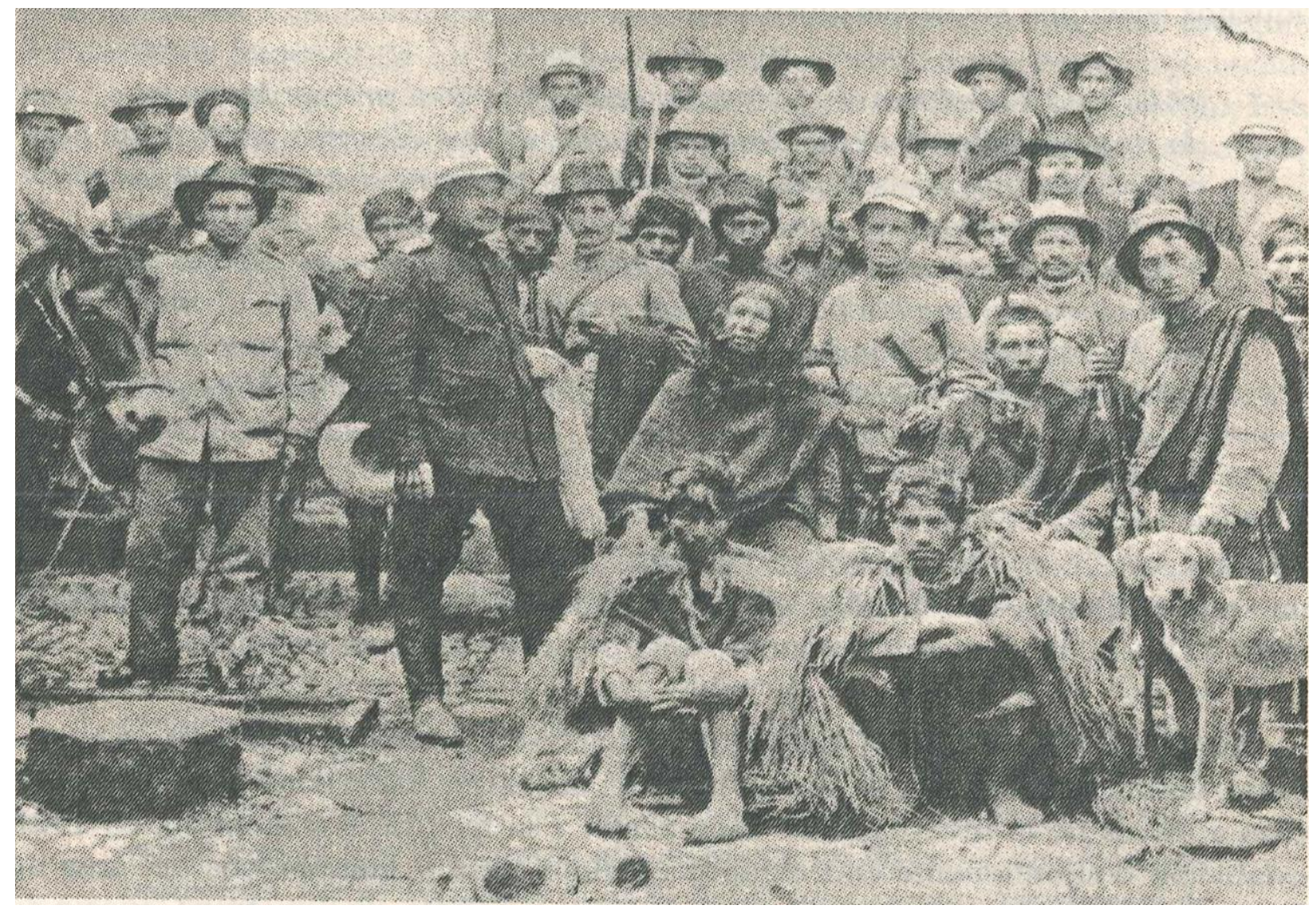

Figura 4. Manuel Quintín Lame. Lame se ve en el centro de esta foto, con el pelo largo y un tabaco en la boca. 1916, Lame es arrestado en la ciudad de Popayán 5 .

Em 1919 o Congresso colombiano aprovou a lei 104, impondo um grande número de comunidades indígenas a obrigação de se dissolver, disposição que foi endossada por outras leis em 1922 e 1927. Da mesma forma, em 1941 e 1951 o governo nacional estendeu a lei 89, de 1890.

Multiplica-se então no departamento de Cauca decretos e regulamentos departamentais lidando com final com guardas em 104 direito das divisões de guardas de 1919, que será completado pela lei 19, sobre o mesmo assunto em 1927. Em 1926, com o Decreto n ${ }^{\circ} 435$, o governador do departamento de Cauca "no exercício do poder conferido pelo artigo $41 .^{\circ}$ da lei 89 de 1890" promove a implementação dos sectores da população, ou seja, a segregação das parcelas dos guardas, para transferi-los para os

${ }^{5}$ Foto de Diego Castrillón, 1916, Popayán.Tomado de RAPPAPORT, 2000, p.159. 
municípios, como a terra que é para barracas e vendem a particulares (FINDJI; ROJAS, 1985, p. 96).

O decreto diz em seu artigo primeiro:

As câmaras municipais exercerão livremente Atribuição conferida pelo artigo 15 da lei 89 de 1890, observando razões suficientes de porções de guardas para as áreas de população, não só os chefes de municípios, mas as aldeias que têm alguma importância na opinião dos respectivos conselhos.

A expropriação violenta dos territórios coletivos das salvaguardas e medidas para integrar os povos indígenas à ordem nacional iria intensificar durante as décadas seguintes, apesar da forte mobilização dos indígenas do início do século XX. Se o político conservador Mariano Sendoya iria deixá-lo em seu trabalho

nossos índios foram dizimados nos últimos anos de 1930 até aqui pelos colonos e bandidos para tomar suas terras e culturas, sem encontrar a autoridade que os protegem, também pelos empregados e administradores das fazendas onde eram terrajeros, onde foram tiradas violentamente, movendo suas colheitas ao poder dos agricultores sem consciência que fulminou sem pagar-lhes as melhorias ou seus herdeiros terrajeros velho de titulação, quando eles morrem (SENOOYA, 1975, p. 182).

Esta medida de desapropriação e assentamento dos territórios indígenas é consistente com a política de branqueamento ou miscigenação vem aplicada desde o século passado. Ou seja, inserir brancos colonizadores que fornece ou reconhece a usufructuó da propriedade privada, no meio dos guardas comumente habitado por áreas indígenas, tornando-se finalmente colombianos para "civilizá-los e cristianizar os".

Antes que o ressurgimento das pretensões de culturalmente integrar os povos indígenas em expropriar seus territórios coletivos, as pessoas nasa optaria por tomar parte em processos organizacionais diferentes de suas formas tradicionais de identidade nacional.

Assim, integra as ligas camponesas e sindicatos agrários que tinha sido fermentando o nascente revolucionário socialista partido da Colômbia com mestiços sem-terra ou descendentes 
de povos indígenas e pessoas de ascendência africana, que eram pequenos agricultores, meeiros e trabalhadores. No entanto, estas formas de organização iniciado a partir da individualidade de suas afiliadas e não pela Comunidade que representa os povos indígenas, que os levaram, em muitos casos a tentativa contra formas comuns de organização indígena. A ignorância do problema indígena e doutrinação das ligas camponesas e sindicatos agrários pela vanguarda proletária trabalhadores da cidade que levaria o caminho vitorioso da revolução proletária, que as pessoas nasa longe destes processos organizacionais e optou por continuar à procura de uma proposta organizacional.

A organização e a mobilização de diversos setores sociais populares a reação do governo, proprietários de terras e beneficiários de classe média emergente pequeno negócio do status quo foi rápida. Dando início uma nova onda de repressão que a historiografia colombiana chamaria maiúscula e itálico como o período de violência (1946-1964). Neste período de violência, as elites dos partidos tradicionais que procurou impor um modelo de modernização, de acordo com diretrizes liberais ou conservadoras do estado nacional iria enfrentar. "Visto como processo político nacional, violência, resulta de um lado, o confronto de elites combativo e outro, sectarismo localista que afogava todos os grupos, classes e regiões do país" (PALACIOS; SAFFORD, 2002, p.632). O que é recrudecería do assassinato do líder liberal Jorge Eliecer Gaitán no dia 9 de abril de 1948, que se originou a destruição de grande parte do centro de Bogotá e intensificar a luta de morte entre os apoiantes dos dois partidos políticos em diferentes regiões do país. Chamada de violência, guerra não declarada entre os partidos liberais e tradicionais preservados pelo domínio do poder, vai ser diferente dos que o precederam no século passado.

Ahora se imponía a las clases dirigentes la necesidad de cerrar el paso a la creciente organización de las masas populares, cuyo ascenso comenzaban a vislumbrar como un peligro para la estabilidad del sistema (BONILLA, 1979, p. 354).

Este clima de terror impostas pela repressão e morte sua Assembléia pela classe dominante em concubinato com a Igreja Católica, seria explorado e promovido por latifundiários e políticos para entrar violentamente, privando os povos indígenas de suas terras.

O período de violência, enfrentando os liberais e conservadores e organização política, impediu a ascensão dos setores com várias propostas coincide com a expansão da fronteira agrícola 
em direção as territórios coloniais reservas indígenas, no departamento de Cauca. Juntar a nova colones antigos proprietários vindo para constituir fazendas café, cana de açúcar e gado sob colonização da fazenda de Murua existente modelo. Tornando-se os proprietários de colonos para reduzir os proprietário ancestral em terrajeros de sua própria terra, como lhe tinha acontecido desde o século passado.

É importante para o stress que estes novos proprietários começando a subir na frente ocidental da cordilheira central durante o período de violência não são de origem aristocrática, mas os colonos que vieram em outros lugares no país pelas medidas adoptadas pelo governo para lidar com os territórios indígenas e o anseio pela riqueza e imobiliário. Devido a esta nova agressão e seu declínio organizacional, as nasa pessoas não encontram uma saída diferente de milhares de camponeses que estavam em uma situação de opressão e submissão semelhante. Se juntar às fileiras do Liberal e armados de guerrilha comunista que se opõem resistência o violento ataque que o governo pretende acelerar o desenvolvimento económico do país e as demandas dos setores populares insatisfeitos com a ordem estabelecida e crescente classe operária a afogar-se.

A participação do povo da nasa em organizações de guerrilha reafirma les mais uma vez a necessidade de estabelecer uma organização indígena própria que lhes permitia avançar suas lutas com outros setores populares, mas de suas próprias exigências como indígenas, mantendo a sua autonomia como povos originalmente. Desde as plataformas políticas da insurgência e organizações agrícolas, ao qual pertencia o forro de processos revolucionários como proletários agrícolas, não como uma coletividade culturalmente diferente e em muitos casos, concebendo-os como parte de um passado pré-capitalista deve superar para dar forma à revolução proletária. Dando forma às experiências locais de organização comunitária, liderada por indígenas sem-terra que tinha sido saques em décadas anteriores. "Tais experiências forçaram uma ruptura com a atitude do dócil das Cabildos subjugadas pelas pressões dos grandes proprietários rurais e autoridades políticas da região." (PEÑARANDA, 2012, p. 24).

No início do primeiro governo da frente nacional que represento a reconciliação dos dois partidos tradicionais que tinham sido confrontar violentamente por mais de um século, as lutas e tensões sociais, no departamento de Cauca se intensifica.

Por un lado, la Violencia había impulsado procesos de expansión de las haciendas o de asentamiento de colonos, muchos de ellos fugitivos de otras 
zonas, en tierras pertenecientes a los resguardos; de otra parte, el anuncio de la implementación de la Reforma Agraria había estimulado la expulsión de muchos terrajeros de las haciendas, ante el temor de una inminente reclamación de estas propiedades; al tiempo que las acciones del Ejército en contra de los grupos insurgentes asentados en el oriente del departamento amenazaban a la población indígena, mientras que la proliferación de bandoleros y ex-guerrilleros en el norte, había incrementado notablemente los niveles de inseguridad, con el aumento de delitos como el robo y el abigeato, y la aparición de nuevas modalidades delictivas como el secuestro. Finalmente, la expansión de la industria azucarera y su impacto sobre la tenencia de la tierra sería determinante en el desarrollo de los conflictos sociales, particularmente en la zona norte del departamento. (PEÑARANDA, 2012, p. 23)

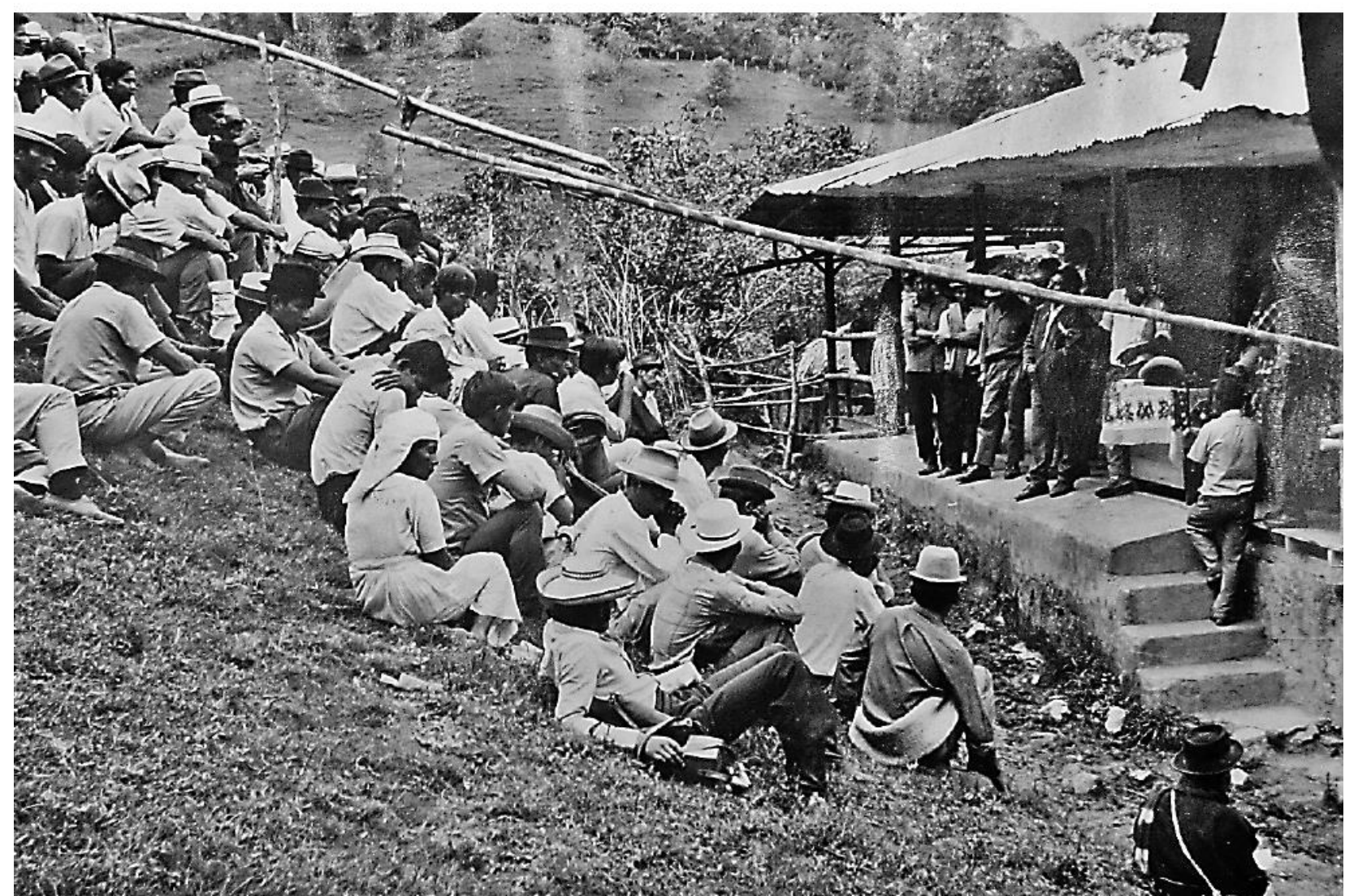

Figura 5 Primeras reuniones de constitución de una organización indígena en el departamento del Cauca ${ }^{6}$.

\footnotetext{
${ }^{6}$ Foto de la oficina de comunicaciones del CRIC. Tomada de Nuestra vida ha sido nuestra lucha. Resistencia y Memoria en el Cauca indígena. Informe del Centro Nacional de Memoria Histórica de Colombia, 2012.
} 
Em 1963, um grupo de nativos do abrigo de Jambaló e Sílvia constituída Caucano a União do Oriente que nos guarda, que articulou a lutar para a recuperação de suas terras, servir como um elo entre os dois povos para resolver problemas de contorno e encarar a humilhação a que foi submetida pelos povos indígenas na Colômbia.

Mas neste organizacional ocorrer falha e não pode desenvolver, entre outras coisas porque seu conteúdo eram válido, eles não compreende todas as aspirações da Comunidade nasa e Guambiano. Também pela mesma Constituição, de forma da União de outros à realidade das comunidades indígena que queria organizar. (BONILLA, 1979, p. 356)

No entanto, serviu como antecedente imediato para a criação do Conselho Regional indígena de Cauca-abri no mês de fevereiro de 1971. Esta seria a primeira organização indígena da Colômbia e teria um papel chave na Constituição subsequiente de outras organizações indígenas regionais e nacionais. O Conselho regional indígena de Cauca-abri o é gestaría no âmbito do processo de recuperação de suas terras ancestrais que povos indígenas veio para a frente.

No município de Toribio em 24 de fevereiro de 1971 mais de dois mil indígenas membros dos 7 conselhos do departamento de Cauca reuniram (Toribío, Jambaló, San Francisco, Tacueyo, Totoro, Guambia e Chinaya), bem como várias organizações camponesas indígenas municípios de Miranda, Corinto, Caloto, Santander de Quilichao, Puerto Tejada e outros municípios do Norte a Cauca.Durante desta casa é determinada e autorizado a plataforma política do abri que consiste de 7 pontos : recuperação de terra usurpada por proprietários de terras, constituição e ampliação de reservas, reforço de cabildos e formas tradicionais de governo, recuperar e assumir a autonomia indígena, não há mais pagamento de Murua, apresentar legislação indígena e assegurar a sua aplicação, de defesa da história, cultura, costumes e línguas dos povos indígenas e preparar professores indígenas bilíngües (Consulte o trinado Morales 1979).

Esta plataforma de luta são mantidos com algumas modificações e complementação como controle social, contribuição para a paz, participação política e outros aspectos básicos que convergem em quatro pilares: território, a autonomia, a cultura e a unidade.

Pouco depois foi constituído de três de seus fundadores e líderes recuperações de abri segue a gestação da organização. 
As lutas do terrajeros de Ana Silvia e o Credo em Caloto, norte del Cauca, serviram como pano de fundo para a formulação da abri. Numa reunião no Credo a idéia de uma grande montagem indígena para o qual foi proposta para Toribio como local central para as comunidades do Norte e a leste e a data de 24 de fevereiro de 1971, foi nomeada. Promoção e organização do camponês Assembly foi responsável por FRESAGRO, organização militante camponesa do norte do Cauca sediada em Corinto, que havia tomado em suas mãos a bandeira da luta pela terra em momentos em que as Diretivas regionais dos usuários ainda eram muito influenciadas pelos promotores oficiais. (Tunubalá; Morales: Valencia, 1974, p. 25)

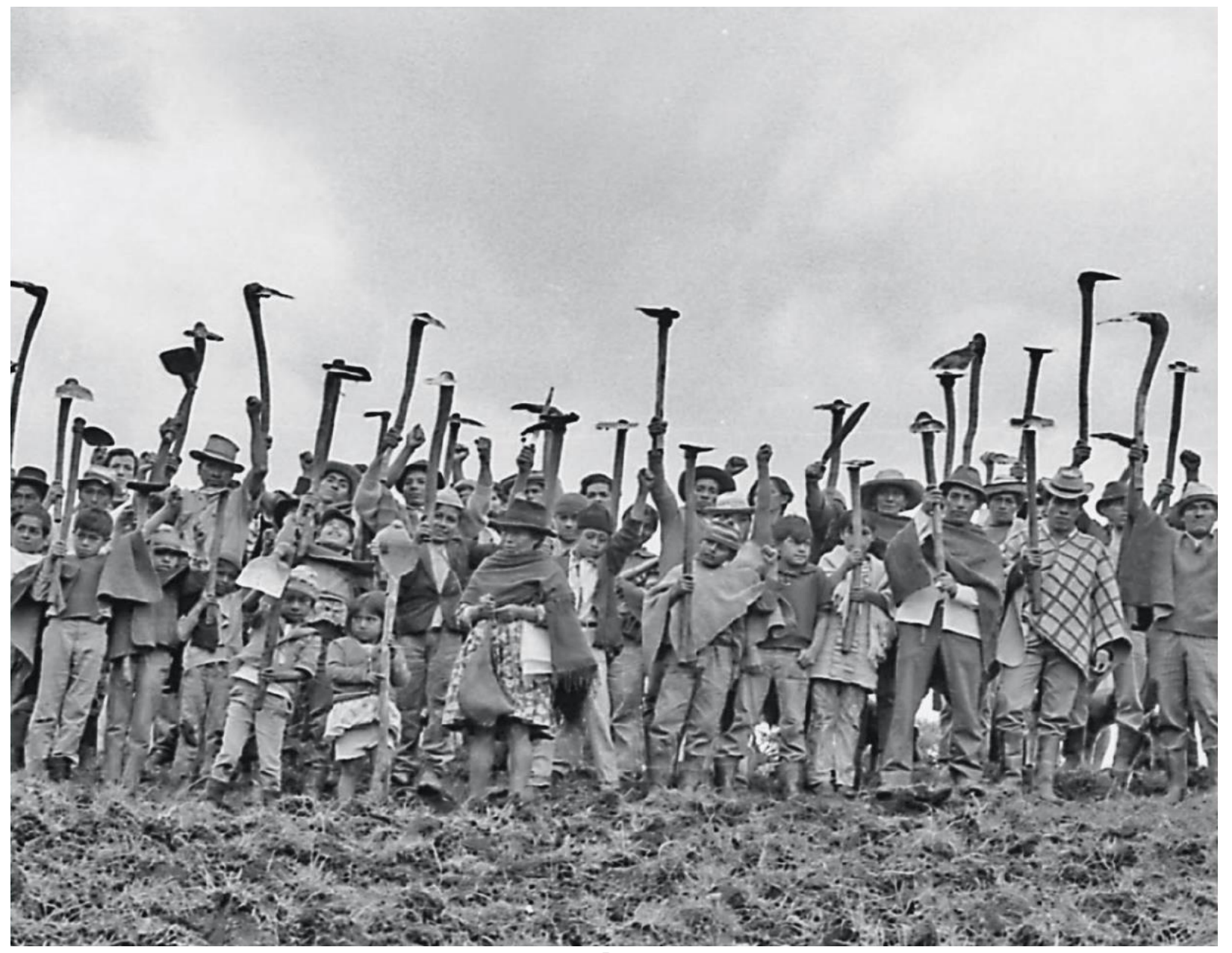

Figura 6 Recuperación de tierras Hacienda Cobaló, Cauca 1974.

\footnotetext{
${ }^{7}$ Foto Jorge Silva, 1974. Tomada de Nuestra vida ha sido nuestra lucha. Resistencia y Memoria en el Cauca indígena. Informe del centro nacional de memoria histórica de Colombia, 2012.
} 
O estabelecimento do CRIC como própria organização indígena, vista a defesa de seus territórios, culturas e legado indígena de costumes de experiência política acumulada na historicidade dos povos tinha Colômbia presente, mas especialmente o povo nasa.

Esta perspectiva foi o que levou à criação desta organização original: um regional, do Sul, do Conselho, de acordo com a realidade regional. Produto de realidade para a mesma história de tempo (compartilhado por mais de três séculos) de exploradores ou explorado companheiro indígena e não indígenas. Mas um Conselho igualmente indígena, porque a experiência acumulada em falhas sofreu nas últimas décadas tenta organizar de acordo com outras fórmulas, designou-lhes a necessidade de uma organização própria. No entanto, a visão da necessidade para este tipo de organização não é traduzida em termos étnicos, mas que o abri foi criado como uma União de Paeces, guambia nos e outras comunidades (BONILLA, 1979, P.356).

Durante as décadas dos anos 70, 80 e 90, a abri é caracterizado por uma vigorosa mobilização vista a recuperação e a defesa dos territórios indígenas e a rejeição da interferência do governo e interferências de grupos insurgentes nos assuntos da Comunidade. Também, como para a defesa da vida devido a violência desencadeada pelas organizações de direita e esquerda contra os povos indígenas, levando a instalação bem sucedida de organizações políticas independentes.

A mobilização durante este estágio teve como principais objetivos a recuperação de terras comunais e um processo de identidade de reconstrução, através do reforço das autoridades tradicionais e a recuperação dos valiosos traços culturais, como a linguagem, inclinandose para todos sobre a reinvenção da tradição histórica. Estes objetivos foram alcançados amplamente no decurso de quarenta anos, quando então novos objetivos, como aumentar espaços políticos regionais e a luta pela autonomia territorial, foram atraídos. (PEÑARANDA, 2012, p. 22)

O CRIC é um dos pioneiros do movimento indígena na América Latina. Seu lançamento, em meio a inúmeras dificuldades, representa um enorme desafio, explicando, para ser uma experiência muito especial de mobilização dos diversos atores sociais, com uma base étnica. 
Originou-se no contexto político e social no final dos anos 60 e início dos anos 70 em que as consequências da violência das décadas anteriores era evidente em áreas urbanas e rurais. Violência relacionada com a reorganização econômica e social do processo de modernização na Colômbia. Neste sentido, a luta social do abri representa a gestação de um espaço organizacional do povos indígenas em busca de um melhor diálogo com o estado e a sociedade nacional para defender seus direitos, independentemente, participando das lutas de diversos setores sociais para mudar a correlação de força existente. De acordo com Pablo Tatay fundador da CRIC

la idea central es que el poder no se toma sino que se construye. En este sentido, nuestra organización hace parte de la progresiva construcción de un poder propio que busca no sólo integrarse en igualdad de condiciones al Estado existente, sino ir poniendo las bases, junto con los demás sectores sociales, de un nuevo país y un nuevo Estado, sin exclusivismos, con la participación de todos. (TATAY, 2012, p. 54)

A experiência organizacional do Conselho regional indígena do Cauca-abri e outros processos nacionais, zonais e locais que têm surgido e crescido em sua sombra ao longo de mais de quatro décadas, mostram como a vontade criativa dos povos indígenas tem conseguido superar os obstáculos políticos e sociais que limitam a sua ação. Que parte do processo de luta e resistência de mais de quatro séculos dos povos indígenas de Cauca, sobre uma proposta de política, não uma simples reação desesperada a adversidade representada por forças fora de seus interesses.

Uma vez que suas ações são carregadas com uma intencionalidade política e cultural que fornece uma interpretação e reinterpretação consentimentos do passado que tem permitido a reinvenção das identidades e tradições culturais. Daí, que, apesar dos vários ataques que têm sido e continuam a ser sujeitos, para continuar a lutar enquanto não desligar o sol como o hino da nasa pessoas mencionado.

Em 1980 o abri e outras organizações indígenas regionais, zonais e locais, promovem em participarem ativamente do primeiro Congresso Nacional indígena, que teve lugar em Lomas de Hilarco, município de Coyaima, no departamento de Tolima. Isto surge a coordenação nacional indígena da Colômbia, que um ano depois, em Bosa Cundinamarca em uma nova reunião com a participação de mais de 9 organizações regionais se tornou a organização nacional indígena da Colômbia FARAÔNICOS. 
Devido a luta persistente, os povos indígenas eram capazes de participar na Assembléia Constituinte de representantes de três 1991con que teve um papel proeminente, Lorenzo rodas (misak indígena), Francisco Rojas Birry (terra indígena embera) e Alfonso Peña Chepe (indígenas da nasa). Na nova Constituição política foram dedicados às regras fundamentais de direitos étnicos e o quadro geral para as relações entre o estado e os povos indígenas. Princípios básicos da carta referem os seguintes aspectos centrais: reconhecimento e a protecção da diversidade étnica e cultural, a reafirmação do caráter inalienável dos territórios indígenas e proteção de terras comunais, criação das entidades territoriais indígenas dentro da terra da nação em reconhecimento a autonomia dos grupos indígenas e suas próprias formas de governo.

A constituição de 1991 estabelece o caráter multiétnico e multicultural da sociedade colombiana, o que significou uma ruptura histórica, porque pela primeira vez uma Constituição reconheceu os povos indígenas como parte integrante da sociedade nacional, na época, que lhes dá uma série de garantias para assegurar a sua existência como sujeitos coletivos de direitos. "O Estado reconhece e protege a diversidade étnica e cultural da nação colombiana" (artigo 7. o , constituição da Colômbia, 1991). As mudanças ocorridas com a promulgação da constituição de 1991, "são um passo importante para o reconhecimento da identidade e da autonomia indígena" (DOVER \& RAPPAPORT, 1996).

As Constituições que precederam você contemplam a Colômbia como um país de "um idioma: castelhano, uma única religião: o catolicismo e de uma cultura única: a Colômbia." (PADILLA, 1996, p. 80) Fornece um do principal constitucional altera o artigo 330, que dá a povos indígenas o direito de governar seus territórios de acordo com seus "usos e costume.

Entendiendo estos "como un grupo de principios ético-morales, que se encuentran articulado a un conjunto de conocimientos bastante amplio de narrativas mítico-cosmológicas, rituales, proceso de diagnóstico, terapéuticos y encaminamiento de decisiones políticas (PEREIRA, 2012, p. 17).

Dando autonomia indígena na organização administrativa, financeira e judicial de seus territórios, bem como uma jurisdição eleitoral especial que lhes permite ter representação permanente no Congresso. Os novos regulamentos que regulam a relação entre o estado e os povos indígenas foram implementados num contexto da política de descentralização que fornece mais 
espaço de participação dos cidadãos na administração pública local, departamental e nacional. Situação que será explorada pelos povos indígenas em geral e a nasa de Cauca em particular para liderar a criação de organizações políticas independentes, permitindo-lhes capacitar os novos espaços e mecanismos de participação cidadã. Como é o caso dos movimentos cívicos no norte de Cauca que são criados na poção para a tradicionais festas e clientelismo político, para contestá-los no controle da administração pública a nível local ou municipal, departamental e nacional campo eleitoral.

\subsection{A concepção histórica do povo Nasa}

A abordagem histórica que eu fiz nos parágrafos anteriores em grande medida baseou-se nos documentos elaborados pelos repórteres e pesquisadores. Modo linha e cronológica, acha que é importante abordar a concepção histórica na memória coletiva do povo nasa aldeia seu uso político. Enquanto isso não é o objetivo do presente estudo, essa abordagem para a historicidade do povo da nasa é essencial para abordar a gestão e governação dos seus territórios indígenas coletivos do município de Toribío. Desde que isto distorce a ideia prevalecente na historiografia colombiana por um bom tempo.

Apresentando os povos indígenas como seres refratários para mudar, como um resíduo de um passado sem história, como grupos insignificantes em via de extinção e, portanto, sem qualquer capacidade política. Para negar a existência de historicamente válido em seus respectivos povos experiências. Mas a historicidade dos povos indígenas, alegação de que eles têm um futuro que são agentes de seu próprio destino. (BONILLA, 1979, p. 325)

A historicidade do povo indígena do povo nasa mostra que sua luta ancestral de resistência para é por manter seus territórios e culturas, não é um produto de um instinto irracional de sobrevivência ou oposição cega de defesa à desapropriação. Mas parte de um projeto coletivo que permite que eles lutar por sua autonomia e independência.

Dificilmente um exemplo melhor do que a historicidade do povo da nasa será encontrado para fazer uso da tradição política dos povos indígenas, para promover a unidade e a continuidade dos seus povos, que expressa o próprio desenvolvimento político que são direcionados. Não é 
surpreendente, portanto, que o Paez ter concedido a Juan Tama o lugar preferencial em sua tradição: filho das estrelas e protetor de seu povo, como eles ainda se lembra dele com respeito (BONILLA, 1979, p. 325).

De acordo com a utilização e o desenvolvimento da memória coletiva na vida cotidiana, o povo nasa, as pessoas não conceber da história como um linear e cronológica é narrada formalmente o raciocínio ocidental eurocêntrico. Em vez disso, sua interpretação do passado é representada pela figura da estrutura espiral e se manifesta de maneiras diferentes em suas práticas e costumes, no território que habitam, a retórica política usada e elementos de sua cultura material.

O tempo é como uma roda, girando, é como um anel, que se transforma ao mesmo tempo; Então é assim que marca o sol sobre a terra, assim é a maneira em que os passos do arco-íris quando a aleta dá um arredondamento. Mas é também como o caracol ou o arco-íris, que têm uma articulação que diz respeito a todos e marca o tempo ou período. Tempo volta, passa e retorna. Falar da história implica um fluxo que não é linear, mas não circulares. É como uma espiral em três dimensões, cujo centro está no topo. Muitas pedras em vários povoados de abrigo são esculpidas com petróglifos; entre eles há uma figura dominante, a espiral. Simples, duplo, registrado em círculos concêntricos, sua presença é óbvia e repetitiva. $O$ tradicional chapéu de homens e mulheres, formadas por uma longa fita tecida com vários tópicos que podem ser costurados em espiral a partir de um centro, repetiu a figura do caracol. Os idosos podem ser lidos na história, bem como a sua visão da sociedade como um todo e como as coisas estão interligadas. A origem do tempo e do espaço é marcada sobre ele. É o seu centro, tudo começa e lá novamente (BASCO, 1993, p. 10-11).

Esta noção de espaço espiral foi desenvolvida por pesquisadores indígenas que de categorias linguísticas e terminologia temporária, descreve o tempo como algo que é enrolado e desenrola-se em várias bandas temporárias. (Ver Rappaport 2008) O linguista indiana Barbara Hurtado (1995) é o vinco e implantação do espaço geográfico e social, que define a relação dos povos indígenas andinos ao longo do tempo, a ação de rolo e desenrole. 
Nos anos depois, na época, vivia em sua jornada através da vida e do mundo, os ancestrais têm marcado um caminho, tem aberto um caminho por onde aqueles voltando, seus descendentes hoje, devem avançar para fazer história. O passado vai para o futuro e o futuro volta. É como se nossos antepassados retornam para encontrar seus descendentes ou como se aqueles que já partiram (morreram) retornam para julgar o que seus descendentes tem feito na sua ausência. Isso é como se dando uma volta na circular grande espaço, um reencontro com o ancestral, o presente e o futuro, uma ilusão, uma esperança do pensamento indígena. Espaço que está à frente e o tempo gasto (preservando tradições) orientar a vida do homem. Eles vão para a frente na vida e na vida após a morte. O espaço que é deixado para trás e o tempo ainda não viveu são um espaço e tempo para se desenvolver (REBOLOS HURTADO, 1995, p. 35-36).

De acordo com a pesquisadora Joanne Rappaport concepção de história presente em muitos povos indígenas de andinas na Colômbia situa-se na topografia em que residem e outros elementos que fazem parte da sua identidade.

O passado, como lembrou-se de histórias e como ela é vivida na paisagem, na parte inferior dos elementos da cultura material, que inclui sítios arqueológicos e a roupa também é lido. Fornece validação empírica consistente de narrativas orais, cujo conteúdo é desenvolvido no território. O passado é projetado simultaneamente para a frente sobre a política de vir (RAPPAPORT, 2008 p. 183).

A memória coletiva do povo da nasa e sua concepção do passado está intimamente ligados às táticas de resistência desenvolvida ao longo de séculos de relações interétnicas e sua visão de mundo. Neste sentido, é uma reapropriação do passado para transformar o presente e planejar o futuro através da retórica política que encontra-se em seus discursos e práticas da Comunidade. Historicidade que dá base para a recuperação do seu território para provar uma ligação ancestral com ele.

Os nasa tem registrado a história de sua luta na geografia do território que tem sido habitada desde os tempos antigos, para que o passado e o presente está localizada em território que culta, 
caminhando e defender. Memória que foi construída sobre uma estratégia complexa de memórias em que o passado distante e recente se cruza com o presente na topografia. Esta historicidade está imerso em um palimpsesto de prazos e miticos-historicos atores que estão relacionados a determinado lugares topográficos. Uma maneira de ler o passado que está em desacordo com a interpretação hegemônica que é feita dos povos indígenas da história nacional.

A historicidade do povo nasa e outros povos andinos é enrolada e desenrola-se, movendo-se frente e volta a partir de hoje para o distante dos últimos ancestrais e em direção ao passado mais recente de abuso no rancho e o ponto de viragem na recuperação da autoridade do cabildo e a recuperação de terra usurpada. Isto não é uma narrativa cronológica linear, mas um constante retorno aos momentos-chave na história dos povos indígenas, que aparecem de novo, como ensinamentos importantes (RAPPAPORT, 2008, p. 187).

O caso da espiral do povo da nasa poderia começar com uma vertente que se origina em um passado próximo, um incerto presentes e futuras, avançando ou recuando volta para trás e da frente para trás.

Como foi o caso da história ouvida durante uma reunião do programa de etno-educação, realizado em setembro de 2014 no recebimento de Tacueyó. Uno dos coordenadores do programa de etno-educação comunitária começou seu histórico história vila nasa com o avalanche e o terremoto que devastou a territorialidade da região ancestral de Tierradentro em 1994, seguiu com uma guinada em direção ao interior da espiral e menção para a cacica que defendeu os territórios ancestrais de a invasão espanhola e a morte de seu marido e filho, venham matar Juan de Ampudia e derrotando Sebastian de Belalcázar. Contínuo com uma torção para dentro da espiral, voltando no tempo para um evento anterior, a criação do mundo e a nasa como povos nativos, passando à frente de endereço, o grande chefe do século XVIII para Juan Tama star e outras figuras míticos momentos na história, fechar a espiral com os desafios, as pessoas nasa como cultivos ilícitos o conflito armado e as reivindicações das corporações transnacionais.

Reinterpretando a determinados momentos de sua historicidade, de acordo com necessidades e circunstâncias políticas em que são evocados de reinterpretar o passado no presente 
e futuro. Sendo referências que derivam seu poder de sua articulação dentro do contexto político e social em que são aplicados (vê Benjamin 1968).

As histórias da historicidade do povo da nasa não estão em uma ordem cronológica, seus criadores justapõem diferentes prazos por omitindo a explicação causal e abster-se de narrar os acontecimentos linearmente ou localizar estas fora do tempo cronológico. Isto não significa de qualquer forma que é desconhecida para a linearidade dos acontecimentos. Compreendido e abordado em outro contexto e de forma diferente, não necessariamente dentro da mesma narrativa.

A naturaliza não-narrativa, episódica e sem um estilo definido desta natureza conceito histórico é fundamental para o objetivo perseguido: sua flexibilidade e ambiguidade permitem usado de maneira diferente em vários contextos (RAPPAPORT, 2002, p. 40).

Sendo a história enquadrada no território estão vivendo, não só geografia transmite importantes momentos históricos e personagens que estrelou, também organiza a maneira como esses fatos são conceitualizados, lembre-se e organizar dentro de uma estrutura temporária (ver Hanyood1976; Rosaldo 1980). A narrativa estabelece que sua precisão por provas pode ser confirmado na topografia, a cultura material e as práticas e instituições da comunidade de autogoverno.

A espiral que representa a historicidade da cidade nasa move-se fora do tempo linear para desenvolver a partir de eventos que assumem um carácter simbólico, torção que faz se movendo para frente e para trás no passado recente mais, bobinamento e desbobinamento de acordo com as circunstâncias políticas em que a reinterpretação do passado é necessária. Desde o nascimento sobrenatural dos chefes, para a origem das coisas e do mundo, justapondo estas referentes histórica e mítica experiência contemporânea, que revela diferentes períodos de tempo

Claramente isto não é uma narrativa cronológica, mas uma história feita conscientemente envolvimento e desempacotamento, dispõe de uma série de espirais cujos contornos são ditados por topográfico fundadores humanos vivos e as demandas políticas da luta indígena (RAPPAPORT, 2008, p. 189).

Historicidade do povo da nasa são o produto de experiência direta nos últimos momentos icônicos e reinterpretação de aqueles que resistiram durante séculos pela tradição oral, histórias 
que datam de diferentes lugares e momentos históricos ou míticos, em sua visão de mundo. Como o mito e registros históricos documentados são mutuamente justapostos.

Quem fez estas histórias são baseadas em uma grande variedade de fontes documentais, variando de documentos legais e livros escritos pelos membros da sociedade dominante, até produto de memórias pessoais de oral, bem como a geografia dentro da tradição de ter o lugar da história. O reflexo do passado é uma maneira de mudar as condições de que eles são, incorporando o conhecimento extraído da interpretação histórica para as lutas políticas para transformar o presente.

Estas histórias fazem uso do registro documental como uma série de imagens trouxe à mente e que estão relacionados com o presente. É dizer sobre conteúdo histórico é determinada pelas reivindicações que você tem que recorrer a eles. Uma vez que estas são um teste empírico que fornece a base histórica e jurídica suas reivindicações em relação ao território habitado desde tempos antigos.

Como foi o caso de títulos de real das muralhas do século XVIII. A historicidade do povo da nasa reapareceu em várias formas, seja na forma de documentos legais, como os títulos concedidos pela coroa espanhola para os chefes do século XVIII, que confrontou encomenderos e donos de terras durante a colônia e mais tarde a pretensão de homogeneização do estado. Ou de narrativas de míticas e históricas de recriar e reinterpretar através da tradição oral, diversas personagens e momentos que sustentam sua comunidade práticas em relação à sua visão de mundo.

Transmissão da informação que formou a memória coletiva do povo da colônia até hoje, a nasa da tradição oral e interpretação dos documentos existentes nos testes escritos que procurava que legitimasse suas aspirações políticas e territoriais. Movendo-se personagens e momentos da história a ser parte da memória coletiva, como é o caso das batalhas legais e militares com o gaitana cacica durante a conquista ou Juan Tama da estrela na colônia.

O caso do povo nasa é, portanto, de uma minoria subjugada que tenha perdido o controle da verdade histórica para os guardiões tradicionais dos arquivos e a verdade histórica que se transformou em uma verdade jurídica que tem exercido uma influência permanente ao longo dos séculos (RAPPAPORT, 2000, p. 38). 
Concepção histórica que configura a memória coletiva da nasa aldeia, mesmo que tenha um personagem mítico ser ligada à sua visão de mundo, baseia-se a reconstrução dos fatos e personagens históricos de determinado tempo e lugar, como está registrado por uma grande documentação existente na estos. Se ocupa os eventos do passado como os dilemas presentes e futuros, fazendo uso do mito, o ritual, a topografia sagrada e documentos legais como cordões umbilicais que ligam os diferentes momentos do tempo. Neste sentido, a historicidade do povo da nasa é um veículo político que lhe permitiu desenvolver relações com o território que habitam, que permite organizar uma resistência política baseada na reinvenção cultural de sua identidade ao longo do tempo.

A resistência política do Paeces assim envolveu várias estratégias para garantir a sobrevivência em meio a uma decididamente adverso para um projeto de vida próprias realidades socio-políticas, que torna admissível supor que traços culturais adquiridos nestas circunstâncias tem formado um local profundo em torno do não-indígenas e várias ameaças, produto das relações históricas com a sociedade nacional (GOMEZ; RUIZ, 1997, p. 37).

O território é a parte decisiva na historicidade do povo da nasa, não só porque no que é representado, mas porque, apesar de sua redução substancial devido o saque que tem sido ao longo da história, ajudou a preservar e recriar elementos da identidade indígena na vida cotidiana que se desenvolve na. Como é o caso das práticas de governo e organização social que permitem a apropriação indevida e significado, de dimensão mítica e simbólica.

O que torna o território o elemento constitutivo da experiência histórica da nasa. A retórica política utilizada pela nasa para defender seu território desde a chegada dos espanhóis, até hoje, mantém a historicidade como o epicentro da natureza de suas demandas e ações para alcançá-los. Fazendo uso da sua interpretação e reinterpretação da história como uma ferramenta para enfrentar a situação de subordinação são. Tornando-se uma forma de conhecimento sobre as origens desta situação e uma fonte de informação para os seus direitos legais. Também gera Zemelman: "não interessada em tudo no passado, apenas aqueles aspectos que poderia servir como uma base para promover processos de transformação". (Zemelman 2001 p. 30) 
Esta política de uso de conhecimento histórico vinculado ao presente e futuro com o passado, a questão fundamental para fortalecer a identidade coletiva que permite diferenciar-se culturalmente de surround ou sociedade global.

Sendo que a história determinada pelo uso político que é feito, ele não é mais uma questão de estática e torna-se uma escolha a forma representam o passado no presente e futuro, sendo esta interpretação da última parte de um processo histórico. Desta forma, há uma reapropriação do passado do uso que vai dar representação histórica e não simplesmente da memória nostálgica do que aconteceu.

A memória coletiva do povo da nasa não é o registro de uma série de documentos, histórias e prontamente trouxe à memória e imagens relativas ao presente, ou seja, aquelas relativas à histórica cujo conteúdo pode ser analizados67independientemente, como se eles não são determinados por fatores como as pretensões políticas. Em termos de Fals Borda: "memória coletiva crítica convida a ação, fazer algo de concreto para corrigir injustiças... A história gerou novos toques de veracidade e poder. Não somente poderia ser lembrado, se não convertida em ação de catapulta para gerar uma melhor de vida coletiva "(Fals Borda, 1985:89).

Neste sentido, acordadas Greg negando (1988) história é o que é considerado como tal no presente e não o que realmente aconteceu. Interpretação histórica informa mais sobre a apropriação do passado no presente que o passado em si (Ver Portelli 1991).

Os consentimentos de reapropriação do passado que faz parte da retórica política das reivindicações do povo da nasa, ele permitiu a reinvenção da identidade. Concebendo a cultura como o produto de sua historicidade e não uma essencialista a perpetuação de uma tradição.

O passado só é útil na medida em que lança luz sobre os problemas do presente. A nasa não tem uma simples curiosidade sobre os eventos do passado, mas que eles refletem sobre eles e suas ramificações no presente. As histórias tecidas por narradores nasa contêm imagens usadas desde os tempos antigos, mas os conteúdos são o produto de situações sociais e novas relações e modelos que organização são o resultado de um processo de transformação gradual que teve lugar ao longo dos séculos (RAPPAPORT, 2000, p. 219). 
Esta reapropriação da memória histórica de uma perspectiva política permite revelar o projeto e tiveram como povo. Assim como as estratégias de dominação que participaram em toda a história e as estratégias de resistência que lhes permitiu a enfrentá-los. (Ver Zemelman 2001) Neste sentido, de acordo com Fals Borda (1985), a recuperação da memória tem um emancipatória, sendo um elemento constituinte do sentimento de identidade cultural.

Para reapropiarse as comunidades em sua história, recupere figuras, símbolos e projeções ideológicas que permitem que eles se opõem a uma interpretação da história para a versão oficial que ignora-los e subordina as meganarrativas que legitime as condições existentes. Dando-lhes uma identidade coletiva através do reconhecimento de sua própria história e tradição (Fals Borda, 1985:92).

Em outras palavras, a concepção histórica, a nasa tem sua própria lógica interna, interpretada e reinterpretada, século após século, enfrentando novas circunstâncias políticas. É um sistema simbólico que existe dentro da Comunidade, permitindo-lhes entender de onde vêm e para onde eles foram, tendo de apresentar como eixo articulador.

Reinterpretando o processo histórico no que sus através de suas ações políticas narrativas lhes permitiram defender seu território e cultura. Assim, transformar o passado em um artefato político que dá legitimidade às suas reivindicações no presente e seus projetos no futuro.

Em seguida, com o segundo capítulo desta pesquisa passaremos para observar o processo de descentralização e a alocação especial étnica do orçamento nacional para povos indígenas, através da vinculação dos guardas ao sistema geral de participação-GSP, como parte das reformas do sistema de administração pública local, do reconhecimento da diversidade étnica e cultural pela constituição de 1991 da Colômbia. 


\section{CAPÍTULO 2 - DESCENTRALIZAÇÃO ADMINISTRATIVA, ESTADO MULTICULTURAL E POVOS INDÍGENAS}

Neste capítulo vou a abordar descentralização da administração e governança local que faz parte das políticas multiculturais relacionada com o reconhecimento constitucional do carácter multiétnico e multicultural da sociedade colombiana. Para alcançar este objetivo é começar com que uma geral contextualização histórica da descentralização da gestão e administração pública local, contínua análise cultural direitos territoriais diferenciais e a alocação especial étnica do orçamento nacional para os povos indígenas através do envolvimento dos guardas como entidades territoriais indígenas de caráter especial e de transição para o sistema geral de participação-GSP. Para medir a importância deste tema no contexto colombiano, apresentou algumas informações demográficas gerais sobre a Constituição dos povos indígenas previstos no último censo da população em geral de 2005.

Acabei de apresentar a implementação institucional dos Cabildo para o regime geral de participação de ligação e as limitações estruturais e tecnocráticas são impostas pela participação dos povos indígenas na gestão e governação local, desde que esta ligação que alegadamente visa garantir o direito de governar os territórios indígenas coletivos de acordo com os usos e costumes das comunidades. Ser persistente, as incompreensões e os efeitos paradoxais entre uma visão liberal da governação, a dinâmica do reconhecimento étnico promovido pelo Estado e avanço e afirmou próprias de organizações indígenas e de governo da comunidade de processos.

Por causa que Michel de Certeau (1976) chama como "Despertar indiano" na América Latina, mobilização étnica em Colômbia conseguir que o estado abandona asimilacionista o projeto eu chá para mais de um século e reconheceu a diversidade étnica e cultural. O que significa uma importante mudança nas relações das comunidades indígenas com o estado e a sociedade nacional. Mudança que seria registrada na constituição de 1991 que reconheceu a Colômbia como uma nação multicultural e multiétnica e instou o estado para proteger essa diversidade cultural. "O Estado reconhece e protege a diversidade étnica e cultural da nação colombiana" (artigo 7. ', constituição da Colômbia, 1991).

Artigo $7{ }^{\circ}$ da Constituição da Colômbia representa uma ruptura histórica, pela primeira vez que uma carta magna reconhece os povos indígenas, afro-descendentes e rom como parte integrante da sociedade nacional, ao tempo que lhes dá uma série de garantias e de direitos a fim de garantir 
um tratamento diferenciado na política pública de acordo com suas especificidades culturais, com o objetivo de preservar o seu carácter e peculiaridades como um grupo étnico.

Com este reconhecimento do carácter multiétnico e multicultural da sociedade colombiana que estado procurou recuperar a legitimidade perdida em áreas habitadas por indígenas e afrodescendentes. Reconhecimento de que constituiria em um projeto de modernização do estado de corte neoliberal, expresso na proposta de descentralização territorial. Reconhecendo o estado de indígenas e Afro-descendente como interlocutores políticos ser sob as figuras de guardas e conselhos comunitários, lhes dá o direito de gerenciar e planejar a gestão independente de seus territórios étnicos. Apresentando um ambiente de desacordo e contradição à visão do público na dinâmica de descentralização administrativa, promovida pelo Estado e os processos de autonomia defendida por organizações indígenas. Enquanto grupos étnicos comprometeram com o fortalecimento dos mecanismos e esquemas de comunidade participativa dos governos, o estado promove políticas e medidas económicas desfavoráveis para o desenvolvimento e consolidação dos processos de autonomia local.

Com este reconhecimento do carácter multiétnico e multicultural da sociedade colombiana que estado procurou recuperar a legitimidade perdida em áreas habitadas por indígenas e afrodescendentes. Reconhecimento de que constituiria em um projeto de modernização do estado de corte neoliberal, expresso na proposta de descentralização territorial. Reconhecendo o estado de indígenas e Afro-descendente como interlocutores políticos ser sob as figuras de guardas e conselhos comunitários, lhes dá o direito de gerenciar e planejar a gestão independente de seus territórios étnicos. Apresentando um ambiente de desacordo e contradição à visão do público na dinâmica de descentralização administrativa, promovida pelo Estado e os processos de autonomia defendida por organizações indígenas.

Enquanto grupos étnicos comprometeram com o fortalecimento dos mecanismos e esquemas de comunidade participativa dos governos, o estado promove políticas e medidas económicas desfavoráveis para o desenvolvimento e consolidação dos processos de autonomia local.

\subsection{Processo de descentralização política e administrativa do Estado Colombiano}

A história do processo de descentralização do Estado colombiano é dividida em dois períodos, o primeiro seria a fase pre-constitutional, que teria sua maior expressão na eleição popular 
de prefeitos no final da década dos anos 80 do século XX; e a segunda fase de constitucional, a partir da estrutura jurídica e administrativa propostas pela constituição de 1991.

A dicotomia entre poderes governamentais administrado a partir de um centro hegemônico e a combinação explosiva de necessidades e desejos autonômicos utilizados em outras regiões do país, está presente desde o início da República. É importante perceber as quase cinquenta guerras civis que foram travadas em seu nome durante o século XIX. Assim, no meio de disputas, centralismo foi estabelecido no país como despojos de guerra, com a constituição de 1886, que não eliminar os fatores de conflito entre as regiões e o centro (DUARTE, 2015, p. 142).

Durante o século XX, ao longo de todo o país foi à frente de mobilizações por diversos setores sociais que cimentou em torno de reivindicações, buscando a transformação social, económica e política do país. Das regiões, demonstrando a oposição ao centralismo político da administração pública, impostas pelo estado desde a constituição de 1886.

Estas mobilizações sociais seriam desenvolvidas no meio de uma perda gradual da capacidade de agir do estado.

O Frente Nacional $^{8}$ deixa um saldo negativo, porque o estado era cada vez menos capaz de lidar com os principais problemas do país, especialmente a pobreza e os crescentes desigualdades sociais e regionais. Da mesma forma, o regime mostrou traços indesejáveis, do centralismo na tomada de decisões, de autoritarismo na gestão da dissidência, de nepotismo nas necessidades de cuidados e de exclusão no campo eleitoral." (VELÁSQUEZ, 2009, p. 1).

Neste sentido, o processo de descentralização responde a necessidades técnicas relacionadas com a eficiência e a modernização do aparelho de estado. Mas também para as tensões políticas entre o governo central e suas entidades territoriais locais e regional produto da Aliança

\footnotetext{
${ }^{8}$ Como uma medida política para escapar a violência e depois o governo militar General Rojas Pinilla (1953-1957) os dois partidos políticos tradicionais concordam a um pacto que deve eliminar a fonte central do conflito intra-Partidista, fornecendo acesso equitativo aos benefícios do estado para ambos os grupos; Liberais e conservadores é desigualmente público há 16 anos e alternariam no exercício da Presidência (MELO, 1989). Esta estratégia governamental é conhecida na história da Colômbia como frente nacional (1958-1974).
} 
da frente nacional, a influência da guerrilha em campos e cidades, bem como o aumento do descontentamento civil formalizado através de paradas de produção e demonstrações. Nesse sentido, a descentralização na medida em que o processo antes da constituição de 1991, é desenvolvido no meio de uma primeira escolha entre abertura política e a modernização do estado.

Compreender a descentralização como um processo de redistribuição dos poderes do estado, a favor de uma maior independência, eficiência e papel das regiões e municípios e uma participação mais direta dos cidadãos na gestão dos assuntos públicos locais “(OREJUELA, 1993, P.107).

A crise que enfrenta o sistema político colombiano durante este período do processo de descentralização, antes da constituição de 1991, é um produto do modelo centralista imposto pela constituição de 1886 e referendado pela frente Pacto Nacional. Santana (1983) para o regime político no início de 1980 e da democracia representativa, recolhe seu centralismo, nepotismo e falta de democracia (Santana, 1983:2).

Tornando-se relevante mencionar que os cargos de representação como a direção de prefeitos e governadores foram nomeados pelo Presidente da República nos respectivos departamentos e Bogotá, enquanto outros prefeitos foram nomeados pelos governadores no resto dos municípios do país. Este sistema provocou uma progressiva deslegitimação das instituições "democráticas" de base, bem como a centralização de renda e gastos.

Durante este período anterior a 1991, as reformas da Constituição relacionados ao processo de descentralização e as medidas destinam-se para mudar o sistema político administrativo das autarquias locais ou municipais e departamentais, modificado nas mesmo caminho as relações entre as regiões e o estado nacional.

No sector financeiro, a lei 14 de 1983 estabeleceu um novo enquadramento fiscal para os municípios e departamentos para fortalecer sua autonomia fiscal e administrativa. Esta lei disse que os atributos que pertencem aos municípios e deram as funções para as câmaras municipais para regulá-los. "A lei 12, de 1986, talvez o mais importante da década no campo da descentralização para os municípios, completadas as receitas fiscais municipais com transferências de recursos do nível central." (DUARTE. 2015, p. 146). 
Com a lei 12 de 1986 é delegado para a administração local de parte dos recursos capturados pelo nível estadual central, que estabelece as competências e atribuições dos governos locais no contexto das transferências.

Esta lei também seria a base jurídica do Regulamento do municípios e adiciona-lhes as placas de pensão local (JAL). Em 1987 os decretos de 77 a 80 desenvolve e regulamenta esta lei em relação às novas competências para os municípios, relacionadas a temas tais como: água potável e saneamento básico, construção e fornecimento de escolas, saúde, transportes urbanos, administração educacional e prestação de serviços públicos, entre outros trabalhos.

Em muitos casos locais administrativos poderes conferidos os municípios não estavam sujeitos a planejamento detalhado e autarquias locais ou regionais tinham problemas na gestão sustentável de seus novos poderes. Um do mais importante processo de descentralização é o ato $\mathrm{n}$ - 1 legislativas de 1986, que foi lançado em 1988, introduzindo a eleição popular dos prefeitos e câmaras municipais para reforçar. De acordo com Santana (1988, p. 47-62), a eleição popular de prefeitos em março de 1988 deu-lhe uma nova política de oxigênio, bem como democracia local, para ser o início de uma abertura política que novas expressões políticas deixou centenas de prefeitos no país pela primeira vez.

O experimento político para entregar a soberania, raptada pelo sistema bipartidário, cidadãos correram apesar das mortes e a perseguição desencadeada desde o mais tradicional estabelecimento contra a União patriótica 9 . O genocídio desencadeado contra este movimento com a participação direta dos setores das forças armadas governamentais tentada parar o avanço e a pluralização política da vida local. (Santana, 1988, p.60).

Durante esta pré de fase constitucional destinava-se o processo de descentralização para redistribuir o poder político do estado, que concentrou-se no Congresso e a Presidência. Além disso, começou um processo de fortalecimento da província colombiana de lidar com seus próprios assuntos, a criação de "centros de poder regional" em cada um dos departamentos e especialmente mil centros de poder local (CASTRO, 1998,).

\footnotetext{
${ }^{9}$ En 1984 se presentaron los primeros asesinatos y "desapariciones" forzadas, alrededor de 1.163 miembros de la Unión Patriótica fueron ejecutados extrajudicialmente entre 1985 y 1993, 123 personas fueron desparecidas por la fuerza, 43 sobrevivieron atentados de asesinato y 225 recibieron amenazas durante el mismo periodo.” (Cepeda, 2006, p. 6).
} 
A fase ou período constitucional do processo de descentralização é sintetizado no modelo de estado que contempla o primeiro artigo da Constituição política de 1991, "A Colômbia é uma república unitária, com descentralização e autonomia das suas entidades territoriais".

A autonomia das autarquias locais visa reconhecer as peculiaridades culturais e sociais presentes em diferentes regiões colombianas, para Gabriel Rosas (2010) o princípio da descentralização com autonomia de suas entidades territoriais "foi a interpretação minuciosa de um fenómeno que, depois de muitos confrontos entre federalistas e centralistas ideias, finalmente se expressou sem entorses no padrão" (ROSAS, 2010, P. 3). Neste sentido, uma abertura política do estado de refundação agenciaria através do constituinte de 1991 na qual reestruturaria os fundamentos legais e imaginários da nação.

Esse restabelecimento do estado e a redefinição da nação colombiana, participação indígena em todo o processo da Assembleia Nacional Constituinte de 1991, este teria participação decisiva seria orientada para resolver as questões-chave relativas ao estabelecimento dos direitos diferenciais no novo Estado multiétnico e multicultural.

Também, a definição dos termos da participação dos povos indígenas no estado, para redefinir os princípios da nação os Constituição para incorporar a diversidade étnica. Durante o processo constitucional e no rescaldo colidem visões diferentes sobre a redefinição do estado e da nação colombiana sobre o reconhecimento da diversidade étnica e cultural.

Por um lado, é o modo de exibição de estado e corte neoliberal institucional do reconhecimento da diversidade étnica e cultural. Aceite de visões de mundo, práticas e instituições dos povos indígenas, desde que eles não são contra os interesses da classe dominante para gerenciar o estado e que são enclaves de interesses estratégicos do capitalismo nacional e internacional. Esta visão significa na prática para construir um interlocutor razoavelmente uniforme com o qual era possível negociar a implementação de políticas neoliberais e reformas.

Por outro lado, os povos indígenas, representados através de seus nacionais, organizações locais e regionais expressam uma visão muito diferente do que do estado, estes integração dos povos étnicos à sociedade nacional ser extraída a totalidade das crenças, instituições, modelos de produção e as relações com seu território, envolvendo as culturas indígenas.

Neste sentido, o redefinição da nação para as organizações indígenas da época ansiava como um projeto da Confederação, em que cada povo 
indígena tem o direito de decidir não apenas sobre a conservação do património simbólico mas também em seus modelos de desenvolvimento e riqueza biológicas. Ou seja, o direito à sua própria "autonomia" (DUARTE, 2015, p. 158).

Para Duarte (2015) durante a constituintes e acordo de implementação da política multicultural, que visa assegurar o pleno exercício dos direitos de diferenciais, é presença palpável e confronto de duas concepções divergentes sobre o processo de transformação do estado e da nação colombiana, que nomeou como neoliberal e o Socialdemocrata.

De acordo com Carmenza Saldías (2008, p. 2), os princípios constitucionais da participação, pluralismo e descentralização referidos no artigo primeiro da carta magna, seriam desenvolvidos desde a definição do Estado colombiano, como autonomias regionais, multiculturais e descentralizadas.

Contemplando as autoridades territoriais locais como o epicentro da administração pública, estruturação das entidades territoriais indígenas e multiplicar os canais e mecanismos de participação dos cidadãos, incluindo a eleição popular dos governadores e a ação afirmativa de comunidades étnicas nas legislaturas de estado. Da mesma forma, a criação do sistema nacional de planejamento e o fortalecimento das finanças locais e departamentais.

Revelando a intenção de estruturar um novo ordenamento do território, apoiado pela administração local e reconhecendo os territórios ancestrais das populações étnicas. Assim, enquanto alguns setores da classe dominante e partidos tradicionais estão olhando para a reestruturação do estado e da administração pública, com base numa abordagem neoliberal defendida pela redução e a modernização do estado das delegações de parte de sua concorrência para o mercado, através de terceirização de serviços públicos e setores estratégicos, tais como as comunicações educação e saúde. Povos indígenas, afrodescendentes e outros setores populares no constituinte buscando uma ambiciosa declaração dos direitos sociais e reconhecimento multicultural, que, segundo Ivan Jaramillo eu institui no título II dos direitos, garantias e deveres

Um generoso pacote de direitos para todos os grupos sociais, especialmente as mulheres, mães, crianças, minorias e especialmente os mais pobres e mais vulneráveis. Foi nesta maneira como a carta dos direitos e a descentralização da metade da receita corrente da nação impediram esse 
neoliberalismo é sair com o seu, e que a sua propensão para o mercado produziu a marginalização da população mais pobre e mais vulnerável. Pode-se dizer que o Estado-Providência não entrou em colapso, mas que passou de um modelo focado na oferta para outro centrado na demanda". (JARAMILLO, 2011, 23).

Outro aspecto que gostaria de destacar a nova Constituição em relação à descentralização, seria a ênfase na participação como uma estratégia para recuperar a perdido legitimidade das instituições públicas.

Criando novos espaços para a participação direta dos cidadãos na formulação, gestão e controle dos assuntos públicos. 134 da lei de 1994 ou participação cidadã ato desenvolve o conteúdo do artigo 103, que estabelece mecanismos de participação como: "plebiscito", "consulta popular" e o "referendo"; e abrindo as portas para a participação direta, como o "cabildo aberto", "iniciativa legislativa" e a "revogação do mandato".

Esses mecanismos permitirá a incidência e participação cidadã na gestão e controle das políticas públicas. Da mesma forma participação política no jogo eleitoral, com base no artigo 107 da Constituição e 130 da lei de 1994 que facilita a todos os colombianos o direito encontrado, organizar e desenvolver os movimentos e partidos políticos.

Como parte desse processo de promoção da participação cidadã, estabeleceu a circunscrição especial indígena para o Senado e a circunscrição especial étnica para a Câmara dos representantes, a fim de assegurar a participação dos grupos étnicos no legislativo. Através de organizações indígenas da comunidade trabalham para a representação política eleitoral, na possibilidade de organizar nacional, departamental e municipal ou local da administração pública. Em suma, a abertura política da nova Constituição

Ele dirigiu-se um número significativo de instâncias de participação criados, principalmente, na década de 1990; "muitos deles conformação, instituída em boa parte como um espaço de encontro entre a administração local e os representantes do povo e eles eram principalmente atribuídas funções de iniciativa e supervisão e em menor grau de consulta, coordenação e gestão de vinculação" (VELASQUEZ, 2003, p. 21).

Então, por pesquisadores como Duarte (2015), a reforma do projeto de nação multicultural, 75 
permite a introdução de mecanismos de participação política diferenciada ajudaria para alargar a base democrática do regime político, conflitos descentralizados e racionalizar o uso dos recursos públicos. No entanto, o constituinte de 1991 também faria as alterações legais necessárias para a implementação do projeto neoliberal de abertura econômica do país para acelerar o crescimento e, em teoria, elevar o nível de bem-estar social. Opondo-se a proposta de descentralização e a abertura política da administração pública defendida durante a constituinte, por diferentes setores sociais, descentralização, tomando um rumo

em diante deve garantir maior competitividade do território, o que significava a incorporação de critérios de gestão privada na gestão dos assuntos públicos, produtividade em serviços, eficiência na utilização dos recursos e, acima de tudo, de conversão do cidadão no estado do cliente e as empresas não-estatais.

Nestas circunstâncias, a ênfase não era mais política (abertura do regime, a participação, a autonomia das autoridades subnacionais) e focado em aspectos técnicos do desenvolvimento das capacidades institucionais das autoridades locais. Estratégia de abertura política, descentralização tornouse o instrumento ao serviço da abertura económica "(VELASQUEZ, 2009, p. 22).

Para William Benítez (2009), os governos da década de 1990 conceberam a descentralização como instrumento de política vista legitimar a redução do tamanho do estado. Esta situação foi alcançada pela intervenção do sector público e a criação de condições para uma ação livre e dinâmica das forças do mercado, usando os argumentos da modernização, racionalização do aparelho de estado e a inclusão da economia nacional no contexto da globalização. "Uma estratégia baseada na re-legitimação do regime através da abertura política, tornou-se o trânsito para uma estratégia de apoio à abertura económica" (VELASQUEZ, 2009, p. 182).

Reduzindo consideravelmente o gasto público social em ação social, em áreas como saúde, educação e fornecimento de serviços públicos. Reconhecimento e legitimidade concedida pelo Estado para processos organizacionais, construído sobre uma base étnica, envolveu o diálogo para a negociação dos termos de implementação dos direitos e deveres do Pacto multicultural. Inauguração neste diálogo a natureza liberal do reconhecimento concedido pelo novo estado 
multicultural, na medida em que a construção de uma pessoa indígena também significou a construção de um sujeito indígena uniforme.

O Multiculturalismo, em seguida, reconhece a diversidade cultural através da normalização paradoxal da diferença que visa reconhecer. Em muitos casos, o reconhecimento da diversidade étnica e cultural do Estado colombiano multicultural passei a invenção ou a conversão forçada de hábitos, crenças e precisa inexistente em alguns povos indígenas, ou a relevância que esses mesmos elementos são dadas na cultura ocidental. Estes elementos foram lançados nas áreas estruturais do estado-nação (instituições indígenas, religiões, ONGs) para construir pontes transculturais através do qual é possível tratar de maneira uniforme o amplo espectro da biodiversidade indígena. Algumas das categorias mais relevantes nesse sentido foram: uma única concepção do território (reserva indígena), uma forma comum de autoridade (o Cabildo), a necessidade de uma legitimidade indígena (lei superior ou direito consuetudinário), a ênfase na criação de especializados de etno-Educação centros, a necessidade de adaptar os parâmetros tradicionais do mercado e um medicina de sistema saúde uniforme assim como a necessidade de reinventar-se ou adaptar os critérios ocidentais de 'desenvolvimento' para os indígenas formulários organizacionais, por meio de "planos de vida indígena". (DUARTE, 2015, p. 169)

Neste sentido, a 1991 Constituição dedicaríamos democracia participativa, etnicamente com base em direitos fundamentais e diferenciais. Este sistema foi definido tendo como eixo estruturante, o aprofundamento de uma política de descentralização administrativa concentrandose no local. Mas a garantia do exercício destes direitos através da descentralização de recursos e a privatização de serviços públicos estado coloca uma égide neoliberal que impede a sua plena aplicabilidade. Que, juntamente com a padronização multicultural e a abertura económica, têm desempenhado um papel chave na concepção de um novo ordenamento do território visando a consolidação de uma ordem sem mediações regionais, descentralizada, numa perspectiva do desenvolvimento, guiados pelo mercado. 


\subsection{Descentralização, Sistema General de Participações e direitos dos povos indígenas}

O processo de descentralização da administração pública na Colômbia, aumentando a participação política e administrativa das autoridades territoriais locais, para ter acesso direto aos recursos fiscais. Recursos da administração central para as diferentes entidades territoriais são atualmente conhecidos como participações sistema geral.

Reconhecer, através do artigo 330, da Constituição, o direito dos povos indígenas de governar seus territórios de acordo com suas tradições e costumes e contemplando o artigo 329 a criação de entidades territoriais indígenas, as relações que o Estado tenha estabelecido com populações indígenas na implementação de políticas multiculturais buscando integrá-los no sistema geral de participação adquiriu relevância importante.

Então, tomaremos o processo de descentralização fiscal e a participação dos povos indígenas no presente. Aproximando-se para o que é o General sistema de participação SPG da regulamentação existente, que estabelece o quadro operacional para as relações das comunidades indígenas e a administração pública estadual aos níveis locais, regionais e nacionais. O que nos permitirá conhecer os procedimentos legais estabelecidos para a execução dos recursos alocados para as entidades territoriais indígenas ou seu equivalente.

Também, como o relacionamento institucional predefinido pelo estatuto entre as autoridades indígenas que presidir suas entidades territoriais e as diversas entidades do estado como prefeitos municipais, departamentais províncias, entre outras organizações e instituições da administração pública nacional. Da mesma forma, os limites dessas relações é desvelaram. Como já observou que o reconhecimento do direito de governar os territórios indígenas, de acordo com os usos e costumes do povo, através da criação de entidades territoriais indígenas está relacionado com o processo de descentralização local.

O trânsito a partir da constituição de 1991, que define um quadro bastante amplo de direitos e garantias para Autonomias locais e diferencial dos direitos, encontrar seus limites precisos e sua verdadeira articulação com as prioridades de estabilização econômica com os desenvolvimentos subsequentes da Constituição em suas leis operativas (lei 60, lei 715 e 1176) que acabam quase sempre interpretando o espírito da regra de uma perspectiva neoliberal (Duarte, 2015, p. 175). 
Sendo as unidades territoriais locais o epicentro político do estado de divisão administrativa, atribuindo não é apenas a função do desenvolvimento do seu território e a prestação de serviços públicos, mas também a promover a participação da Comunidade. Link para os povos indígenas ao processo de descentralização com a criação de entidades territoriais indígenas, foi a maneira de integrar definitivamente os territórios de comunidades étnicas por meio de sua participação na estrutura do estado.

As entidades territoriais indígenas (ETIS), como nova figura política administrativa, seria a possibilidade de afirmar a identidade de autonomias territoriais, colocando os territórios indígenas para o mesmo nível de outras entidades territoriais, legais bases para sua operação nos campos legislativos, executivos e judiciárias.

Como expressão de uma nação pluriétnica a nova Constituição dá povos indígenas maior autonomia em sua governança "reconhecer funções de jurisdição no seu território, em conformidade com suas próprias regras e procedimentos, desde que não sejam contrários a constituição e as leis da República" (artigo 246 da Constituição da Colômbia, 1991). Para a administração e o governo dos territórios indígenas do artigo 329 da Constituição contempla a criação das (ETIs), subordinar a sua conformação com as disposições da lei orgânica de planeamento territorial que deve ser acordada pelo governo nacional, com os povos indígenas.

O ETIS como figura política administrativa teria um carácter especial e que seria a nível de outras entidades territoriais como municípios e departamentos, tendo assim autonomia para a gestão dos seus interesses e gestão dos recursos económicos provenientes do orçamento nacional. Os ETIS são legalmente definidos como uma divisão política e administrativa da República (Art. 286), autônoma administrativa e política dentro dos limites da Constituição e a lei (Art. 1 e 287), habitada por uma população indígena e que é regido pelas próprias autoridades assumiram as competências correspondentes.

De acordo a Rappaport \& Dover (1996) o Estado colombiano define o ETIS em termos materiais, sociais e culturais, como: "uma área geograficamente em que espera-se que os indivíduos sociais grupos governarem a mesmos se próprio de acordo com seus próprios critérios sociais através do Conselho de autoridades indígenas."

Estas mudanças em regulamentações nacionais são parte dos tratados de direito internacional, hospedado pelo Estado sobre a questão da proteção desses grupos humanos, 
ratificando o ato 21 de 1991, a Convenção n ${ }^{\circ} 169$ de 1989, sobre povos indígenas e tribais ILO organização internacional do trabalho -. Isto refere-se na segunda parte desta forma para a questão de terras e territórios: "Devemos reconhecer povos indígenas o direito de propriedade e posse sobre as terras que tradicionalmente ocupam...". Da mesma forma, que "... Os direitos dos povos indígenas aos recursos naturais de suas terras devem ser protegidos especialmente... "." Neste mesmo aspecto, a declaração sobre os direitos dos povos indígenas dos povos das Nações Unidas que o Estado colombiano não era totalmente expostos no preâmbulo da seguinte forma:

Congratulando-se o fato de que os povos indígenas estão se organizando para promover o seu desenvolvimento político, económico, social e cultural para pôr fim a todas as formas de discriminação e opressão onde quer que ocorram; y, "... Convencido de que o controle pelos povos indígenas, dos desenvolvimentos que afeta-los e suas terras, territórios e recursos lhes permitam manter e fortalecer suas instituições, culturas e tradições e promover seu desenvolvimento de acordo com suas necessidades e aspirações (Nações Unidas, 2007, p. 7).

O reconhecimento do carácter multicultural e multiétnico da nação colombiana implica uma reconfiguração do modelo de ordenamento do território e administração do estado da descentralização e a promoção da democracia. As novas entidades territoriais devem articular autonomamente para povos indígenas e o estado nacional. A modificação do modelo de ordenamento do território e administração do estado de acordo com os princípios de uma nação multiétnica e multicultural como a Constituição, diz que teve várias dificuldades, entre as quais a impossibilidade dos diferentes governos concluir com povos indígenas, a conformação da ETIS entidades territoriais indígenas - e orgânico direito indígena.

Para não ter constituído o novo quadro institucional para as relações dos povos indígenas e o estado, o escopo e regulamentação dos direitos diferenciais sobre questões tais como território, saúde, educação, meio ambiente, economia, competência e seu próprio governo a nível local ou municipal são complexas e conflitantes.

Desde a configuração e administração do estado, com base em noções culturais e ontológicas, contrariando os conceitos dos povos indígenas, levou o governo nacional a implementar leis, políticas, tratados ou medidas administrativas que não coincidem com a 
autodeterminação destes. No âmbito do processo de descentralização administrativa e a exigibilidade dos direitos culturais e políticos concedida aos povos indígenas, a constituição de 1991 prevê a criação da (ETIS) como figura política e administrativa para a governação dos territórios indígenas.

No entanto, depois de mais de 20 anos do reconhecimento do direito dos povos indígenas para governar seus territórios de acordo com suas tradições e costumes, entidades territoriais indígenas não têm sido formados ou definidos o escopo e a competência jurisdicional da governação indígena. A fim de assegurar a alocação de recursos do orçamento nacional para os povos indígenas no sistema geral de participação (SGP) reconhece uma designação "especial" para abrigá-los como entidades territoriais indígenas. Na ausência do ETIS e Regulamento dos guardas como equivalente, é necessário abordar o recibo como um territoriais e como atualmente assume o Estado colombiano esta equivalência.

Como já mencionamos no primeiro capítulo que fazemos uma aproximação para a historicidade do povo da nasa, guardas são feitas pela coroa espanhola durante o trânsito da conquista colonial, no século XVI. E eles têm sido usados pelos povos indígenas andinos desde sua origem, para defender seus territórios e culturas para capacitar esta figura política administrativa e colocá-lo ao serviço dos seus interesses.

Desde esta figura representa uma mudança nas relações entre espanhóis e índios, por se entregar pelo menos os direitos coletivos políticos do campo jurídico para os povos indígenas. Reconhecendo a propriedade em seu território ancestral, que forneceu um espaço legítimo para recriar e preservar as tradições culturais. Apesar do ataque sangrento do século XIX, com a constituição da República da Colômbia para os territórios e as culturas dos povos indígenas, eles conseguiram preservar suas instituições e práticas culturais.

Defendo suas identidades e territórios a partir destas instituições, que incluem o recibo e o cabildo. Da mesma forma a guarda desempenhou um papel fundamental na paisagem complexa das lutas indígenas que caracterizaria a região Andina, principalmente ao longo do século XX. Especialmente após o estabelecimento do Conselho Regional indígena do Cauca (abri) e seu compromisso para restaurar e reforçar as instituições e autoridades próprias, como o cabildo e o recibo. 
Contra a historicidade dos resguardos, o Tribunal Constitucional como órgão judicial definiu e exaltar a esta figura ou instituição através do acórdão C-921, 2007.

Convém recordar, que a data de territórios indígenas na altura da colonização espanhola, foram criados por ordem Real e deve seu nome ao fim de "proteger" as comunidades indígenas de despejo, desapropriação e extermínio ao qual estavam sendo submetidos os chamados conquistadores. No início da era republicana libertador decidida retornará "os nativos" guardas que tinham sido atribuídas a eles pelas autoridades espanholas, disposição complementada pelo Congresso de Cúcuta, ordenando que "guardas de terra alocada para os índios pela lei espanhola e que até agora possuíram em comum, ou em porções distribuídas às famílias somente para seu cultivo ... será distribuindo-os em total controle e propriedade, "."

A referida disposição legal envolvido um trânsito da propriedade comunal de propriedade privada, a conotação de território que caracteriza os guardas a sofrer uma mutação e colocando-os como simples terrenos sujeitos ao regime da propriedade real como resultado. A partir da década dos anos sessenta do século passado começou a inverter a tendência de dissolução de propriedade comunal das terras ocupadas por povos indígenas e emitiu regras para garantir sua expansão de reagrupamento e eventual (Tribunal Constitucional, acórdão C-921, 2007).

A Constituição política de 1991 ratificou a natureza jurídica da guarda, da sua tradição histórica, dando seus territórios o caráter inalienável, imprescritíveis, impenhorável e coletivo como artigo $63 .^{\circ}$ prevê-lo. Lançando as bases legais para que os territórios indígenas tradicionais têm autonomia política, desde que eles estavam em conformidade com as leis da Constituição. Dentro de o novo quadro jurídico são definidas algumas das características das muralhas: a) um território definido, b) um título registrado a propriedade comunitária, c) uma ou várias comunidades que se identificam como indígena, d) uma organização interna que rege-se pelo seu próprio regulamento interno. O período concedido decreto 2164 de 1995 em seu artigo 21, define explicitamente que um guarda. 
Os territórios indígenas são de propriedade coletiva de comunidades indígenas, a favor de que são constituídos e em conformidade com os artigos 63 e 329 da Constituição, são inalienáveis, imprescritíveis e irrevogável. O é um status especial sócio-político e jurídico, composto de instituição de um ou mais comunidades indígenas, que com um título coletivo que desfruta as garantias da propriedade privada, têm seus territórios e governam a manipulação desta e de sua vida interior por uma organização autônoma abrangida pela jurisdição indígena e seu próprio sistema de regulamentação (Decreto 2164, 1995, artigo 21).

A estrutura do governo dada aos guardas que é o cabildo, já tinha sido regulamentada durante o período pre-constitutional, através do Decreto de 2001, de 1988, que definiu expressamente o termo de cabildos indígenas, como entidade pública especial, cujos membros são indígenas eleito e reconhecido por um viés em um território determinado, responsável legalmente representar o seu grupo e exercer as funções que creditado a lei e suas tradições e costumes. A implementação do multiculturais direitos coletivos dos povos indígenas, relacionados com a gestão e a posse de seus territórios ancestrais, através do reconhecimento desses direitos das instituições de Estado central.

O reconhecimento político dos conselhos indígenas é responsável pela unidade de assuntos indígenas, ligada ao Ministério do Interior, entidade criada através do Decreto 1634 de 1960, que estabeleceu o procedimento legal para os resguardos indígenas Constituição.

Além disso, o reconhecimento territorial pela constituição de reservas é responsável, de acordo com o decreto 2164 de 1995, do colombiano Instituto reforma agrária (INCORA). Deve notar-se que o INCORA seria dissolvida em 2003, e suas funções são refechadas para Instituto Colombiano para o Desenvolvimento Rural - (INCODER).

É uma função do estado através de INCODER, estabelecer claramente o que é a terra que as comunidades indígenas, como uma arma, vivem garfos ou na propriedade e lá a vislumbrar o que é a concentração, a distribuição e a disponibilidade do mesmo. O procedimento é realizado através de um estudo socioeconômico, jurídico e mandato, em coordenação com as autoridades tradicionais e respectivos cabildos. Esta surge no caso de 
constituição, reestruturação e expansão da reserva indígena, organização de processos iniciados, ofício ou a pedido do Ministério do Interior, de outra entidade pública, ou a comunidade indígena em questão através do Conselho ou autoridade tradicional ou indígena. (DUARTE, 2015, p. 179).

Do artigo 356 da constituição de 1991 é estabelecido em função do conjunto de governo central o que são serviços e competências que corresponde as diferentes entidades territoriais de caráter departamentais, municipais e locais executar em seus territórios. O sistema geral de participação é criado pelo qual deve ser a disponibilização de recursos para cumprir as obrigações inerentes às autoridades locais pelo Estado, por isso.

Reconhecimento da diversidade étnica e cultural do país, especificamente exige do estado a garantia de recursos para entidades territoriais indígenas (quando eles foram criados) ou falha para guardas, tornando-os participantes das receitas atuais dos membros da nação. Recursos para as diferentes entidades territoriais, bem como o destino especial do estado, devem visar o financiamento de prioridade do "servicios11" da saúde e da educação pré-escolar, primária, secundária e média, garantindo a prestação do serviço e a extensão da cobertura.

Em ordem, garantir a alocação de recursos fiscais para servir a funções dentro do processo de descentralização como alvo as entidades territoriais indígenas (ETIS), artigo 357 da Constituição política de 1991, contempla um aumento anual das transferências de acordo com a renda da nação, de uma percentagem igual à taxa de variação percentual que tinha a receita atual da nação nos últimos 4 anos incluindo o ano em curso de execução do orçamento.

É pertinente mencionar que o exercício da autonomia administrativa em recursos fiscais designados para territórios indígenas está subordinado a criação de entidades territoriais indígenas, e desde o 1454 lei, que foi aprovada a lei do ordenamento do território, não tratadas com entidades territoriais indígenas (-ETIS) -, o trânsito de autonomia real fiscal e administrativa cheio de territórios indígenas Continua a ser em atraso. Porque as leis e medidas que regula sua participação nos recursos da nação, através do sistema geral de participação. 


\subsection{Normas e regulamentos do envolvimento dos povos indígenas ao sistema geral de participação-GSP}

Através da lei de competências e recursos ou lei 60 de 1993, houve padrões orgânicos sobre a distribuição de competências, em conformidade com os artigos 151 e 288 da Constituição e recursos distribuídos de acordo com os artigos 356 e 357 da Constituição e outras disposições.

Desta forma, o Congresso obedecer o mandato constitucional para regular um sistema de competências e recursos de transferências; tal que o primeiro critério de execução do orçamento alocado para os municípios e outras entidades territoriais, bem como aplicado: educação, saúde, habitação, água potável e saneamento básico e subsídios para o acesso a serviços públicos básicos para os pobres, entre outros itens. Esta mesma lei estabelece que os fluxos de renda da nação consistem de receitas fiscais e não fiscais, excluindo a partir dos recursos de base de cálculo.

Os fundo e definido pelo artigo 19 da lei como nação 6 1992. 60 lei também estabeleceu as funções e competências que enfrentam as transferências deve ser a nação, departamentos e municípios. Estas competências são determinantes a possibilidade real de interação e harmonia entre as diferentes entidades territoriais e os planos para o desenvolvimento da nação. Bem como instâncias de comunicação e procedimentos que as comunidades indígenas devem ter para a execução dos recursos transferidos.

Além disso, a lei 60 também atribuída a direção nacional de planeamento função DNP de desenvolver atividades de monitoramento e avaliação dos destinos, seguintes artigos 343 e 344 da Constituição política. Desta forma, é atribuída às funções de executivo de monitoramento e controle de orçamentos locais. Para não ter constituído as entidades territoriais indígenas, a lei 60 considera guardas como entidades territoriais transitórias de natureza especial e atribuído a uma participação fiscal equivalente a transferência per capita multiplicado pelo povo indígena reconhecido em seus territórios. Quando a recepção é em dois ou mais municípios, o dinheiro será dividido entre os municípios, a fim de cobrir a população que vive lá.

De acordo com a lei, o município é responsável pela administração dos guardas recusada os recursos, mas será usado exclusivamente para investimentos que beneficiam os habitantes indígenas para o efeito realizado um contrato entre as autoridades municipais e as autoridades de recepção. Determinação de um constante aumento dos montantes das transferências para entidades 
territoriais em conformidade com o aumento dos recursos recebido anualmente pelo Estado, uma provisão que foi alterada com a lei 715 .

Para a lei de territórios indígenas a 60 foi importante na medida em que eu lhes equiparar aos municípios como entidades subnacionais, mas também porque deixo aberta a interpretação da lei com referência as prioridades de gastos, que poderia, em teoria ser planejada independentemente de instâncias participativas de populações indígenas como os assembleis de comunidade (DUARTE, 2015, p. 184).

Em 2001 é modificado através de acto legislativo 01 disposições constitucionais dos artigos 347, 356 e 357 contra a transferência de recursos para entidades territoriais, que eram reguladas nos anos 60, agir, de 1993. Criação do sistema de participação nacional SPG e lei 715 de 2001, que regulamenta as novas disposições referidas pelo ato legislativo.

A lei 715 de 2001 consolidou o desejo presidencial para abrandar o ritmo da descentralização de recursos. Esta reforma claramente estabelecido um período transitório para estabilizar o fluxo de recursos do nacional para entidades subnacionais durante o período entre 2002 e el852008. Assim, entre 2002 e 2005, transferências intra-gubernamentales não cresceria com base no rendimento atual da nação, mas como uma porcentagem da taxa de inflação anual, que é o resumo um percentual adicional de $2 \%$. Portanto, transferências não vinculam-se mais para a receita atual da nação, mas em vez disso, que cresceria em relação à inflação anual. Durante a fórmula dos anos 2006 e 2008, o cálculo seria o percentual de inflação mais um adicional de 2,5\% (DUARTE, 2015, p. 185).

Esta reforma não só significou um corte limitados recursos econômicos que também recebem as entidades territoriais do orçamento nacional, é um recorte das competências relacionadas a direitos sociais concedidos às instituições públicas que têm menos recursos para lhes garantir.

Que as decisões políticas importantes envolvidos cairia dentro do governo central, enquanto as entidades territoriais convertido em agentes de gerenciamento simples da política do governo atual. 715 de 2001 lei não melhorou a situação das entidades territoriais, mas prefiro procurou 
equilibrar as finanças do Governo Central das economias geradas por um método que não se aplica para a indexação das transferências para os fluxos de renda da nação que foi o que decidiu a constituição de 1991, desde que arranjei um valor nominal que cresceria anualmente em alguns pontos percentuais e sob critérios atribuídos.

Além disso, desenvolveu um fiscal territorial regra, há um nacional, que levou o Governo Central para expandir gastos, com uma tendência centralista novamente. O que impediu uma autonomia real fiscal dos municípios e guardas, para a dependência de recurso que é girado da nação. De acordo com Puello-Socarrás (2009) projeto de governo consagrado na lei 715 e reforçado na lei 11762007 "representam uma diminuição líquida de transferências entre 2008 e 2016 para mais de US \$ 76,6 bilhões, dinheiro que estaria disponível para as despesas do executivo central" (PUELLO-SOCARRÁS, 2009, p. 22).

Se as duas Conter- reformas constitucionais e cobrindo o período de 2002 - estágio de pós-constitucional contagem completamente 2016, o cálculo acima teria de ser adicionar $\$ 12,422$ bilhões que foram transferidos durante os anos de 2002-2008. Se levarmos em conta que a lei 60 estabelecido que participação municipal no rendimento atual da nação deve aumentar de 14\% em 1994 para 22 por cento em 2002, é verificado que a lei 715 significa estagnação da taxa de crescimento dos interesses da nação para as entidades subnacionais, incluindo os guardas (DUARTE, 2015, p. 187).

Artigo 83 da lei 715 de 2001, regulamento, a participação dos guardas na distribuição dos recursos no âmbito do SPG. Em relação a lei 60 que precedeu este novo regulamento quer dizer uma mudança em vários aspectos. Municípios, delegando a gestão dos recursos alocados para as reservas na ausência de entidades territoriais indígenas ETIS. Da mesma forma, os guardas definir prioridades para o destino dos recursos atribuídos. Uma das grandes mudanças que trouxe a reforma da lei 60 através da lei 715 foi a alocação obrigatória dos recursos provenientes do SPG nas áreas de saúde, educação e saneamento básico. Desde que sob a lei 60 esses itens apareceram como diversos, que você forneceu uma maior participação na identificação das necessidades em torno de costumes indígenas. 
Para assegurar o exercício dos direitos culturalmente diferenciados, a Constituição prevê que, na medida em que o ETIS não constituirá, guardas que foram legitimamente feitas e relatadas ao Ministério do Interior, o dinamarquês e o DNP, ano que anteceder o termo para o qual os recursos são agendados serão os beneficiários dos recursos atribuídos através do sistema geral de participação SPG. Gilberto Muñoz para antigos municípios de prefeito de Toribío e Miranda, com uma elevada percentagem dos indígenas da nasa, entrevistado durante a segunda semana de novembro de 2014 enquanto participam na Assembleia da Associação dos conselhos ao município de Toribío-projeto da Nasa como candidato nas eleições para o cargo de governador do departamento de Cauca pelo movimento indígena alternativo e Social - (mais), as alterações introduzidas pela lei 715 disposições constitucionais.

Significava na prática que os guardas que eram reconhecidas entidades diretamente como territoriais, em igualdade de condições aos municípios, sob a lei 715 no ato 60 transforma-los em "beneficiários" do SPG, que mesmo quando é não regulamenta o ETIS vai lidar com seus recursos através de projetos que devem ter o aval do prefeito período de perguntas, que representa um revés para as disposições constitucionais de 1991 (entrevista com Gilberto Muñoz no resguardo de San Francisco 12 de novembro de 2014).

\subsection{A governação indígena e o SPG sistema geral participação}

Em resumo podemos dizer que o sistema geral de participação-GSP é uma das maiores expressões do governo colombiano na descentralização fiscal. Sendo um esquema de transferência Intergovernamental de recursos que o governo central entrega seu departamental, distrital e municipais entidades territoriais. Bem como as entidades de natureza especial, como é o caso dos guardas. Esses recursos estão focados para o financiamento dos serviços responsáveis, tais como saúde, educação, água potável, saneamento básico e os definidos pela lei 715 de 2001, 1122 e 1176 de 2007.

De acordo com o esquema de funcionamento do SPG pela direção do desenvolvimento territorial sustentável do departamento nacional de planejamento-DNP, isto é dividido em dois tipos de atribuição ou transferência, por um lado seria as atribuições especiais, que incluem as 
contribuições indígenas para os guardas e por outro mão seria o composto de atribuições de distribuição setorial.

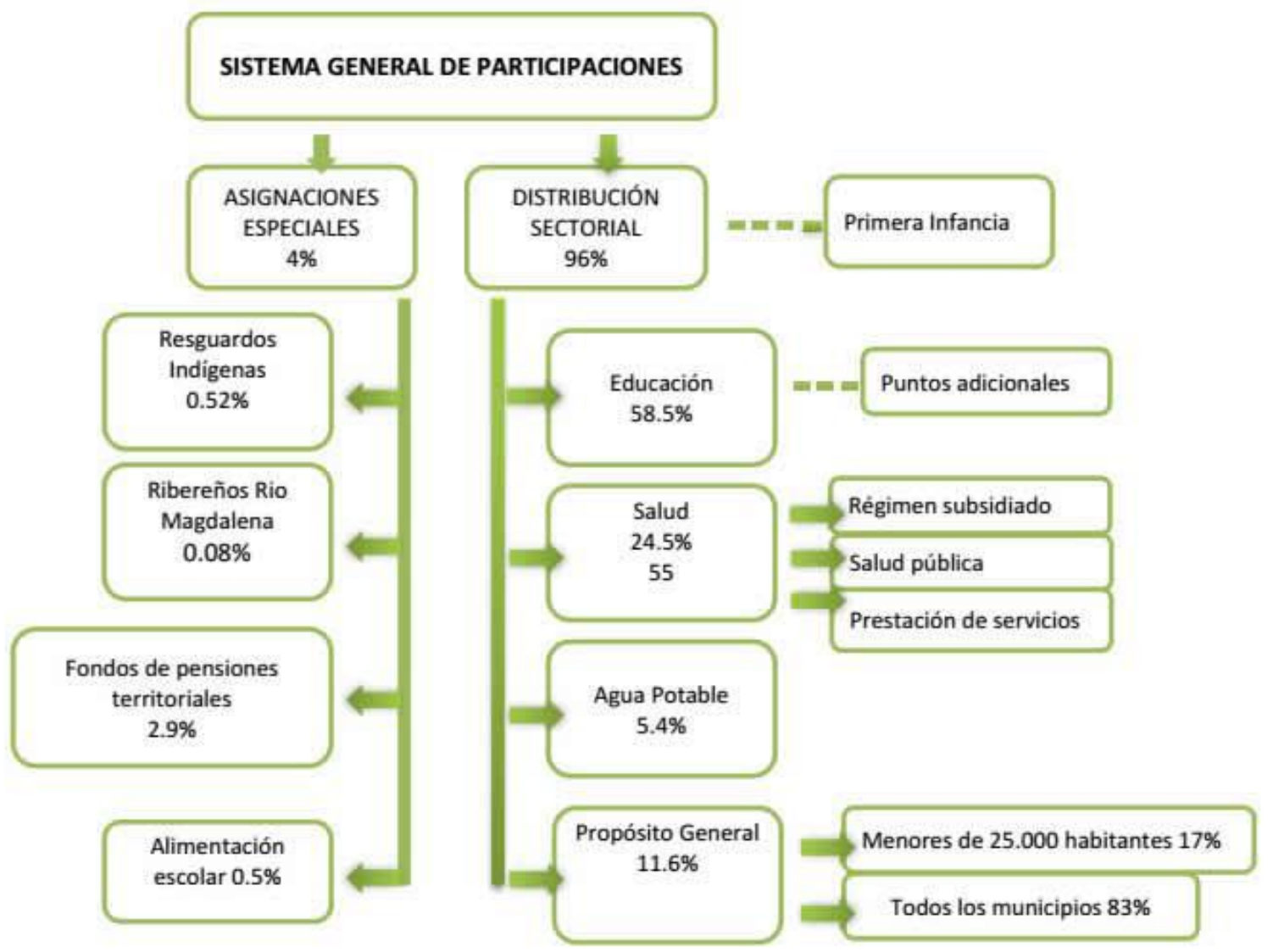

Figura 7 O sentido do desenvolvimento territorial sustentável do departamento nacional de planejamento-DNP.

Nos termos do artigo 83 da lei 715 de 2001, a alocação especial para Resguardos indígenas - recursos AESGPRI são distribuídos proporcionalmente à participação da população de cada reserva em relação ao total da população indígena do país. Aquisição de guarda importante relevância para serem considerados entidades públicas transitórias para uma alocação especial de transferências, dentro do orçamento que recebemos o reconhecimento da diversidade cultural e étnica da Colômbia declarada na nova Constituição.

A implementação das disposições legais da alocação de recursos do sistema geral de participação para os povos indígenas apresentou uma série de dificuldades em relação a configuração do território dos povos indígenas que responde a elementos culturais e diferentes legislações indígenas produzidos ao longo da história colombiana. Para avançar na abordagem para a governação fiscal dos territórios indígenas em relação os recursos do sistema geral de 
participação, abordarei a Constituição dos povos indígenas a partir dos dados demográficos fornecidos pelo último recenseamento geral da população em 2005. Assim como a relação entre territórios indígenas e o reconhecimento destas territorialidades figuras de Estado.

\subsection{Alguns dados estatísticos e demográficos dos povos indígenas na Colômbia}

A população indígena da Colômbia é composta de diferentes grupos étnicos que revelam a diversidade cultural do país. De acordo com os dados da última população censo, realizado em 2005 pelo departamento administrativo nacional de estatística (DANE), em povos indígenas ancestrais de Colômbia 87 são, mas a organização do nacional indígena da Colômbia (ONIC) lá são pelo menos 102 povos indígenas. Segundo o censo de 2005, na Colômbia, o total da população do país era 41.468.384 dos quais 1.392.623 eram reconhecidos como indígenas (DANE 2005), ou seja, que este grupo de população representou $3,36 \%$ da população. Em conformidade com a constituição nacional, o espanhol é o idioma oficial da Colômbia, mas as línguas indígenas também são oficiais em seus territórios. De acordo com o pesquisador BODNAR (2005) no país, 64 línguas ameríndias e diversidade são falados dialetos agrupados em 13 famílias linguísticas.

Os povos Indígenas tem presença ou viver em 27 dos 32 departamentos do país, 60\% desta população está concentrada nos departamentos de La Guajira, Nariño, Cauca e de Córdoba. Aqueles que têm maior presença de população indígena são Amazônia (43,4\%), Guajira (40\%), Guainia (32\%), Vichada (31\%), Vaupés (29\%), Cauca (19\%) e Putumayo (12\%); indígenas com o maior número de habitantes são o Embera, o Wayuu, a Nasa e o Zenú.

\section{Pertenencia a grupo étnico}

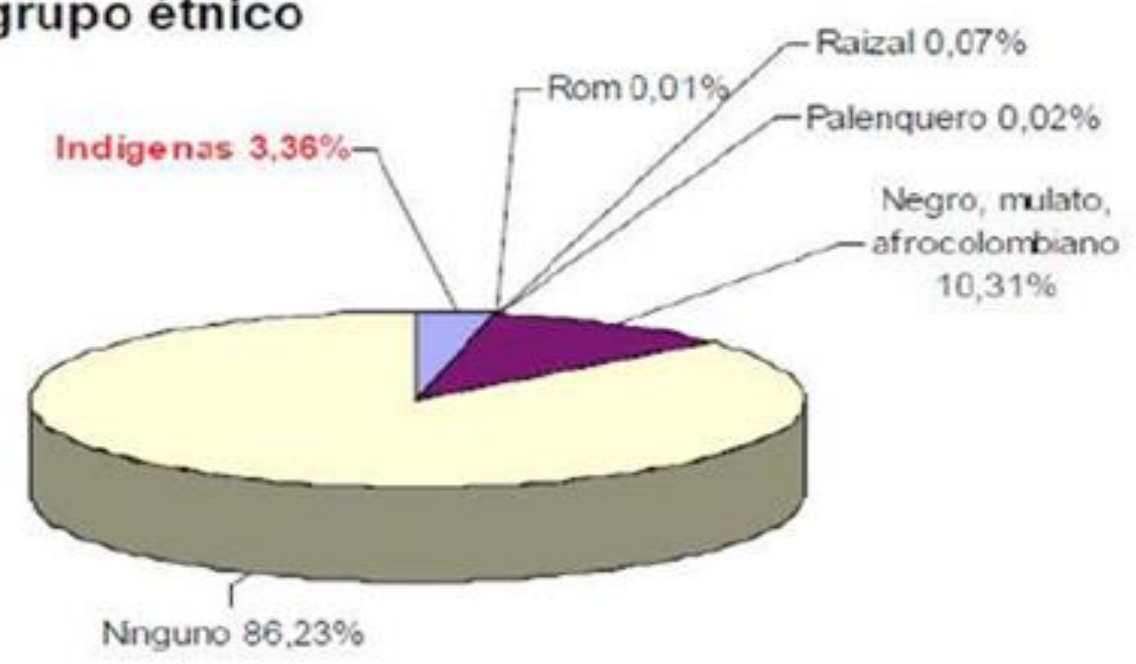

Figura 8 Población colombiana por pertenencia étnica Censo General (DANE, 2005). 
Em termos da sua distribuição territorial, um 78,5\% situa-se na área rural do país nas reservas indígenas legalmente constituídas, no viés indígena, ou territórios não legalmente delimitados. Localizado em áreas naturais como a floresta, as savanas naturais do Orinoco, a Andes colombianos, no nos vales lisos e inter andinos do Caribe. Enquanto 21,4\% vivem em cidades e municípios, como resultado de um processo de migração que responde para o esgotamento das terras dos abrigos, especialmente na área Andina e o deslocamento forçado das comunidades em consequência de conflitos de terra com os latifundiários, grupos armados ilegais e transnacionais nos territórios correspondentes para os resguardos ou grupos indígenas. Um aspecto a ser destacado em relação à população indígena que está localizada na zona rural é que nem todas as vidas na guarda, cerca de um terço do total rural vive em territorialidades que não são reconhecidas como receita, como mostrado na tabela a seguir:

\begin{tabular}{l|r|r}
\hline \multicolumn{3}{|c|}{ DISTRIBUCION DE LA POBLACION EN AREA RURAL } \\
\hline UBICACIÓN & POBLACION & $\%$ \\
\hline En Resguardos Identificados & 770,633 & 70.43 \\
\hline Sin Información de Resguardos & 26,283 & 2.4 \\
\hline Sin Resguardo & 297,342 & 27.17 \\
\hline Total rural & $1,094,258$ & 100 \\
\hline
\end{tabular}

Figura 9 Distribucion de la poblacion en area rural. (DANE, 2005).

Atualmente existem 710 resguardos licenciados, 21 em 27 departamentos e 228 municípios do país, ocupando uma área de aproximadamente 34 milhões de hectares, 29,8 por cento do território nacional. Destes, 64 é colonial e republicano que eles estão localizados nos departamentos de Cauca, Caldas, Nariño e Putumayo. As alterações constitucionais e regulamentos posteriores reconhecem os direitos de propriedade coletiva dos povos indígenas dos territórios que vivem e viveram, exige que vem da colônia. De acordo com isto, títulos coloniais atualmente têm validade jurídica alguma em litígios relacionados com o processo de criação e reestruturação das reservas.

Neste sentido, o Estado colombiano reconhece que a existência da velha guarda (de origem colonial e republicanos) como novos guardas (criadas por INCORA e INCODER), ambos válidos legalmente.

O reconhecimento constitucional da diversidade étnica e cultural e da prestação de direitos culturalmente distintos, um aumento na formação de guardas como parte da afirmação étnica de 
muitas comunidades que antes tem sido de vergonha de ser reconhecidos como indígenas, mas também como acessar as prerrogativas que o quadro operacional do multiculturalismo colombiano dá os guardas como instituição pública transitória de caráter especial.

Esses privilégios são de ordem diferente, em setores como saúde, educação, justiça, acesso a terra, autonomia, e claramente a capacidade de gerenciar recursos financeiros transferidos pelo estado à dotação especial para Resguardos indígenas - sistema AESGPRI. No final de 1993, de acordo com o dinamarquês, qualificadas reservas foram 313 e cobriram uma área correspondente a 22,8\% da área do território nacional. Em 2005 haviam 710 graduados reservas localizadas em 27 departamentos e 228 municípios do país, ocupando uma área de aproximadamente 34 milhões hectares, equivalentes a $29,8 \%$ do território nacional. Estes números mostram um aumento significativo de $127 \%$ no número de guardas e $7 \%$ do território que ocupavam.

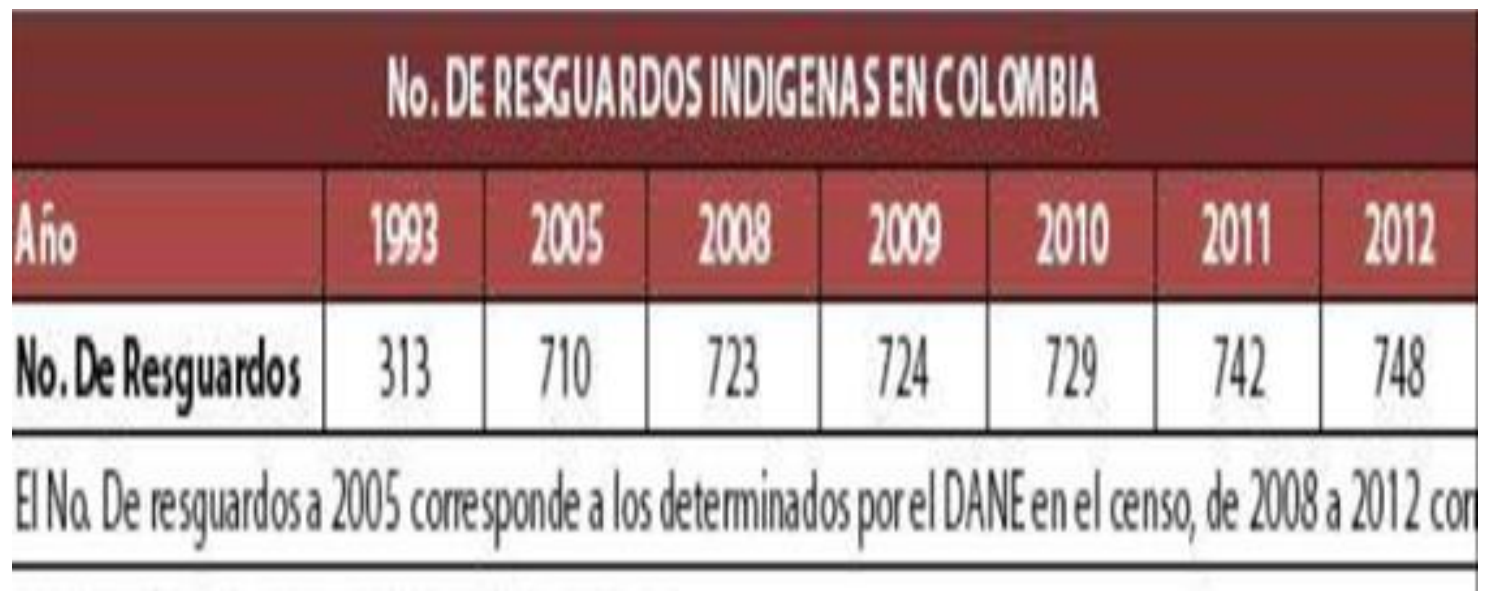

Ilustración 10 Evolución número de Resguardos reconocidos por el Estado. (DANE-DNP-Conpes Social 2008-2012).

De acordo com o acima, vemos a importância que adquiriu o território para acessar as garantias concedidas pelo Estado multicultural para povos indígenas. No entanto, o abrigo salvar é não só existente na figura de territorial destas comunidades. Há também a população que não vivem em reservas ou no coloniais e republicanas guardas que estão no processo de clarificação.

O censo de 2005 identificou que quase $27 \%$ da população indígena rural não vivem em abrigos, parte da população que representa nesta figura ao vivo em territórios adquiridos pelos guardas, mas que ainda não obtiveram o reconhecimento como protegido pelo Estado e, portanto, atualmente são listados como propriedades privadas. Um aspecto que tem incomodado o processo de descentralização étnica e transferência de recursos para comunidades indígenas, está relacionado 
com que existem várias formas de reconhecimento territorial que emanava de estado para as comunidades indígenas em diferentes pontos da história nacional.

Tal é o caso do bias indígenas em mais arborizadas, como o Amazonas e o Orinoco áreas ou qualificações individuais para as famílias indígenas no contexto dos processos de reforma agrária e graus conferidos no âmbito de políticas multiculturais. Outro aspecto complexo do reconhecimento das territorialidades indígenas para a implementação dos direitos multiculturais está relacionado aos processos de clarificação dos títulos do abrigo colonial e republicano, na medida em que esses processos estão em andamento, neste momento, há um estado claramente com referência na medida em que estes territórios terá, desde que em conformidade com disposições diversas do Tribunal Constitucional colombiano a estas áreas que são definidos como ' territórios devem ser adicionados sagrado "de acordo com suas tradições e costumes.

A reconhecida pelo estado através da direção de grupos étnicos do Ministério do interior para 2012 é 748, mas um estudo realizado pelo contraloria13 no mesmo ano identifica 1129 territórios em que diferentes formas de posse indígena na terra foram agrupadas. Partir dos preceitos constitucionais da diversidade étnica e cultural, multicultural Estado colombiano tem participado de dois tipos de reconhecimento para a população indígena.

Por um lado, um reconhecimento político por figuras de "Cabildo" e as "associações indígenas", que é a prerrogativa do Ministério do Interior, à frente do escritório de assuntos indígenas e, por outro lado, um reconhecimento territorial da propriedade coletiva da terra sob a figura de "Guarda indígena", que passa pelo reconhecimento político como cabildo, mas que se aprofunda com a existência de um título de proteção Colonial ou republicano, bem como a exploração da propriedade coletiva nas mãos da comunidade indígena.

Acesso a direitos culturais distintos vai ser fragmentado, reconhecendo o capítulo político e guarda territorial, se levarmos em conta que, nem todas as comunidades indígenas que são autoreconozcan como tal têm direito de tributar as ações decorrentes da alocação especial para Resguardos indígenas - AESGPRI. Desde que a lei 715 determina que somente aquelas comunidades que detêm uma territorialidade coletiva reconhecida pelo Estado como resguardos ou entidades territoriais da nação podem receber transferências fiscais.

A subordinação do acesso aos direitos diferenciais para reconhecimento político e territorial do abrigo e do Conselho levou à constituição desses em contextos muito diferentes, que vão desde 
as áreas urbanas onde uma proliferação dos Cabildos, é apresentado para as zonas rurais, em que as comunidades indígenas formaram conselhos, um grupo de propriedade adquiridos com recursos próprios e espera que o reconhecimento do status de recepção por parte do estado.

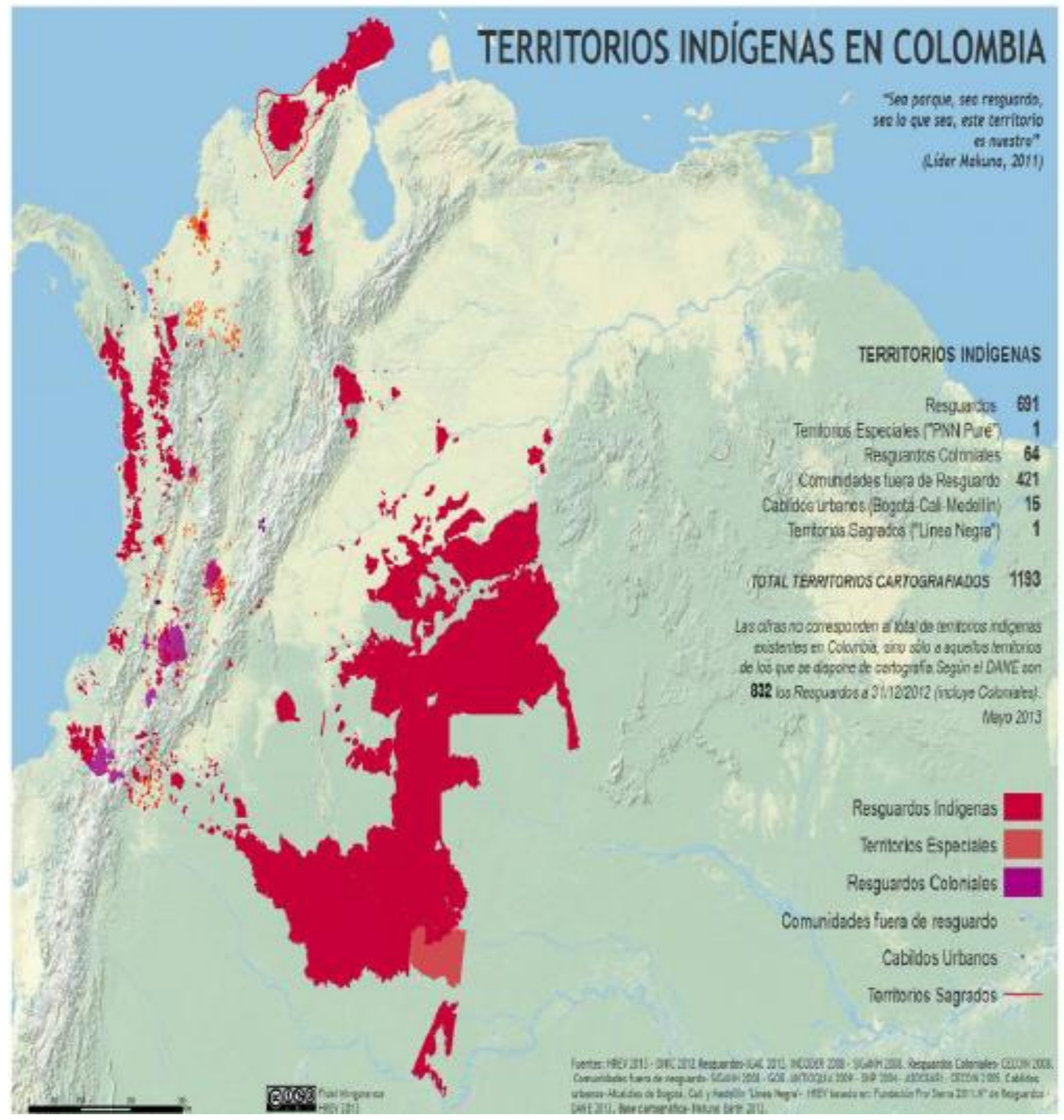

Figura 11 Territorios Indigenas en Colombia.(Contraloría general de la república, 2013 )

Consequentemente, as populações que não possuem titulação coletiva de abrigo, mas que são reconhecidos como Cabildo Indígena sem acesso em direitos diferencial de termos coletivos, na medida em que grande parte desses direitos dependem de um território reconhecido ou apoiado 
pelo Estado como um abrigo. Essas populações têm acesso aos seus direitos como indígenas, nessas instâncias que são projetados para atender a diferença cultural de maneira individual.

La lei 715 determina que só podem ser beneficiários de uma missão especial para Resguardos indígenas - AESGPRI os territórios que são legalmente constituídos como guardas, para o qual o estado delegou essa função ao Instituto Colombiano para o Desenvolvimento Rural INCODER; No entanto, há uma heterogeneidade de territorialidades indígenas que respondem a várias políticas indígenas historicamente implementadas pelo Estado colombiano, que não fizeram a sua validação.

Os territórios que não foram reconhecidos pelo organismo oficial responsável para reconhecimento territorial, ou bem responda a legitimidade política que conselhos rurais para o Ministério do Interior, ou o seu reconhecimento territorial baseia-se em territórios cuja validade é articulada com títulos coloniais que estão ainda em processo de estudo e esclarecimento (DUARTE, 2015, p. 198).

De um modo muito geral, esta é uma apresentação do processo de descentralização da administração pública colombiana, no que diz respeito ao sector financeiro e o reconhecimento do estado dos territorialidades indígenas para o exercício dos seus direitos.

\subsection{Limitações estruturais e tecnocráticas da participação dos povos indígenas no} SPG

O foco dado para os recursos que a nação se transforma em territórios indígenas, bem como os procedimentos que o governo tem estabelecido através do planejamento nacional para a implementação, gerenciamento e desembolso desses recursos nos permitem enfrentar os limites estruturais dos direitos diferenciais para comunidades indígenas de SPG. Nesta secção iremos abordar a operação de governamentalidade estado em matéria de direitos culturais diferenciados, concedido pela Constituição multicultural de 1991, através de mecanismos tecnocráticos que estabelecem os limites das autonomias indígenas.

Como uma instituição pública de municípios locais, é o lugar de nervo do sistema diferencial colombiano de descentralização, já que é justo na cidade onde é a junção entre o estado e visões indígenas com referência a gestão dos recursos, mas também no que diz respeito à interpretação do 
bloco de diferencial dos direitos que a constituição de 1991 produzida (DUARTE, 2015, p. 199).

Artigo 83 do Decreto 715 de 2001, determina a programação da utilização e alocação dos recursos do SPG como uma competência directa das comunidades e autoridades indígenas. Esses recursos devem ser efectuados tendo em conta as necessidades da população, a recepção em cada um dos pontos específicos do decreto.

Um destes pontos é que da saúde, de acordo com regulamentos existentes nesta área inclui projetos para desenvolver ações definidas como prioridade pela proteção Ministério do Social, em termos de: promoção e prevenção, cuidados básicos e ações de proteção específica e plano de deteção precoce.

Outro item é da escolaridade do primário pré-escolar, básico e médio, utilizando os recursos no financiamento de projetos que visam a melhoria da qualidade da educação; Através da construção e manutenção da infra-estrutura educacional, pessoal para estabelecimentos de ensino, transporte, escola alimentação e pagamento dos professores. Água potável e saneamento básico é uma outra área para que as receitas fiscais disponíveis do governo central.

Que são investidos em projetos que atendem o design, estudos e fiscalização das obras para o fornecimento de água e saneamento básico; construção, ampliação e reabilitação de abastecimento de água e sistemas de saneamento; tratamento e eliminação de sólidos, equipamentos para a operação dos sistemas de abastecimento de água e saneamento, entre outros.

Da mesma forma, promove e apóia programas de melhoria e construção de habitação, através da alocação de subsídios para a população que vive em abrigos. E como o último item de foco pelo governo nacional para o investimento dos recursos transferidos para os povos indígenas, é o desenvolvimento da agricultura.

Financiamento a produção agrícola e negócios projetos sustentáveis geradores de renda e/ou permitindo que a segurança alimentar, a transformação da produção primária, marketing e gestão de pós colheita, assistência técnica, proteção do conhecimento tradicional, ajuste tecnológico, atividades de desenvolvimento alternativo, aquisição de terreno para expandir o abrigo e a estrutura melhorada e o saneamento básico para o mesmo. Os regulamentos existentes para a execução das receitas do SPG para os povos indígenas, estabeleceu uma série de competências institucionais para diversas entidades da administração pública envolvida nele. 
É sob a autoridade do nível nacional para definir quem são os povos indígenas e onde eles estão localizados, tarefa que é realizada através de departamento administrativo nacional de estatística - dinamarquês - que devem ser certificada com o "Departamento Nacional de informações sobre a população das reservas indígenas legalmente constituídas pelo município e departamento de planejamento" (159 decreto de 2002).

Neste trabalho participaram antes, Instituto Colombiano para o Desenvolvimento Rural (Incoder), a revolta do censo e a direção dos grupos étnicos do Ministério do Interior, quem certifica-los. O processo de transferência e a aplicação é coordenado pelo Ministério do Interior desde o início até o final do processo, definindo critérios políticos para a implementação de recursos e avaliar a gestão dos governos indígenas. É, portanto, deve ser considerado pelas autoridades locais e os territórios indígenas para a programação e execução dos recursos.

A nível nacional é decidido quem são os sujeitos de direito para as transferências e as prioridades de investimento. Quando guardas obrigados a enviar cópia dos contratos celebrados com o prefeito a executar estes recursos para essa instância.

Os departamentos são responsáveis pela coordenação, controle e monitoramento da ação municipal, treinamento, aconselhamento e assistência técnica através das secretarias departamentais de planejamento para os territórios indígenas e autoridades municipais. De acordo com a lei 715 o governo municipal tem competência para administrar os recursos alocados para os territórios indígenas no âmbito do SPG.

Comunidades no Assembly estabelece as prioridades e quais projetos serão financiados com recursos provenientes das transferências, com base nos critérios de investimento que são decididos a nível nacional, que abordava temas como saúde e educação, de acordo, mas que deixa fora de rubricas orçamentais outras questões centrais para a compra de terras indígenas e fortalecimento organizacional.

Existem opiniões divergentes sobre questões tais como saúde e educação, Considerando que as comunidades que estes temas podem ser vistos como simples produtos e jogos da burocracia não referido como itens de prioridade. Desde que o estado limitado-los para o cuidado fornecido por profissionais de saúde e educacionais instituições, enquanto indígenas comunidades conceberam essas questões de forma abrangente das suas tradições e costumes. 
Uma vez determinada necessidades e prioridade, projetos vai para um Estágio de Gestão, em que você salvar e suas autoridades demonstram todas suas negociação do capital. Esta situação silenciosa substancialmente carrinho da Administração Municipal e suas relações com ou Conselho, são estes forem ideais, ou procedimento formal e ser simplesmente uma exigência legal.

Contador de caso, ou o processo é muito mais complexo e entra não terra das conformidade e presentes pessoais ou institucionais aumento. Para atribuir participação geral concurso SPG fazer sistema de gestão de recursos para os municípios, que devem negociar com uma implementação de muitas vezes competindo com os interesses das comunidades.

"Das transferências de repartição por dois municípios pagam - recibo de gestão política e/ou o Cabildo pelos prefeitos". (Benavides; Duarte, 2010, p.34) Expansivo a apresentar recursos regime dois SPG atribuído aos povos indígenas, e de concorrência da Comunidade do cabildo, através do aquecimento de proativa dos Deliberativo a e membros dos salvar definidos como prioridades de investimento com base nas necessidades identificadas coletivamente. Tempo UMA dada como soluções alternativas ou cuidados das necessidades prioridade ou Conselho deve ser projetos de investimento para a implementação dessas iniciativas. Fazer um Recorde relatado e onde os que existe entre a comunidade de decisões diferentes autoridades tradicionais indígenas.

Acordo, para do regime execução ou utilização dos recursos transferidos para os povos indígenas, localmente no SPG que correlaciona a administração municipal e o Conselho como uma entidade territorial especial de natureza transitória é a configuração nevrálgica do sistema diferencial colombiano de descentralização.

Como a concorrência conjunta do Presidente da câmara e a implementação do Conselho do imposto dividido a partir da conclusão de um contrato entre estas duas instituições. Projetos e orçamentos preparados coletivamente pelos membros da guarda para atender às necessidades de prioridade são a base para o contrato entre o representante legal da nota fiscal e o prefeito ou governador de voltas - conforme o caso - prosseguir com a aplicação dos recursos.

Estes projetos devem preencher por escrito e deve conter os seguintes requisitos mínimos: investimento do setor, nome do projeto, identificado o problema, proposta de solução, beneficiários, resultados e metas esperadas, descrição do projeto, especificações técnicas mínimas, orçamento. Eles devem, tanto quanto possível ser com base nos preços de mercado para facilitar a sua aplicação e para evitar lacunas na programação dos recursos; Além disso, os municípios devem 
tomar medidas para evitar saturações de custo ou custo mais baixo do que o real nos projetos apresentados.

Como mencionado, para o desenvolvimento de projetos que será a base de contratos do gabinete do prefeito e o recibo para a execução da rubrica orçamental atribuído, conselhos tem o apoio dos secretários departamentais de planejamento, que é a obrigação de elaborar e implementar programas de treinamento, aconselhamento e assistência técnica, que deve ser agendada com antecedência e deve ser conhecida por autoridades municipais e comunidades iguais Eles são direcionados para eles fim de coordenar o seu desenvolvimento.

Além disso, a Secretaria Municipal de planejamento tem a obrigação de fornecer assistência técnica e aconselhamento às comunidades para o desenvolvimento de projetos de investimento, orçamento, programação e utilização dos recursos, no momento em que a assistência é solicitada pelas autoridades. As autoridades municipais ou o departamental tem concorrência ou atribuição na alocação dos recursos atribuídos à guarda através do SPG, que é competência exclusiva das autoridades do recibo. A única intervenção que pode ter as autoridades municipais a este respeito, é através de alertas de técnica, quando forem solicitadas pelas comunidades através de suas autoridades.

As cláusulas do contrato devem ser revistas e aprovadas pela administração municipal e o cabildo, a assinatura do contrato pelo representante da recepção e a autoridade da entidade territorial correspondente. Os contratos assinados pelo governador como representante legal das autoridades dos indígenas do cabildo e o prefeito como autoridade máxima da administração municipal são o mecanismo jurídico que permite que você iniciar o processo de administração e execução dos recursos atribuídos às comunidades por GSP, pelos prefeitos municipais ou governadores conforme apropriado.

Representantes da recepção, nem as autoridades do mesmo, pode de bens ou serviços financiados por verbas do General sistema de participação - SPG, pode haver partidas globais onde não especificado los99proyectos despesas a financiar. O contrato pode ter disposições relativas ao estabelecimento de mecanismos de controle e acompanhamento da execução dos recursos pelas autoridades dos abrigos, que são adicionados para as competências dos secretários do gabinete do planejamento departamental e de Controladoria-Geral; o contrato também pode conter uma ordem de prioridade e um tempo de execução específico. 


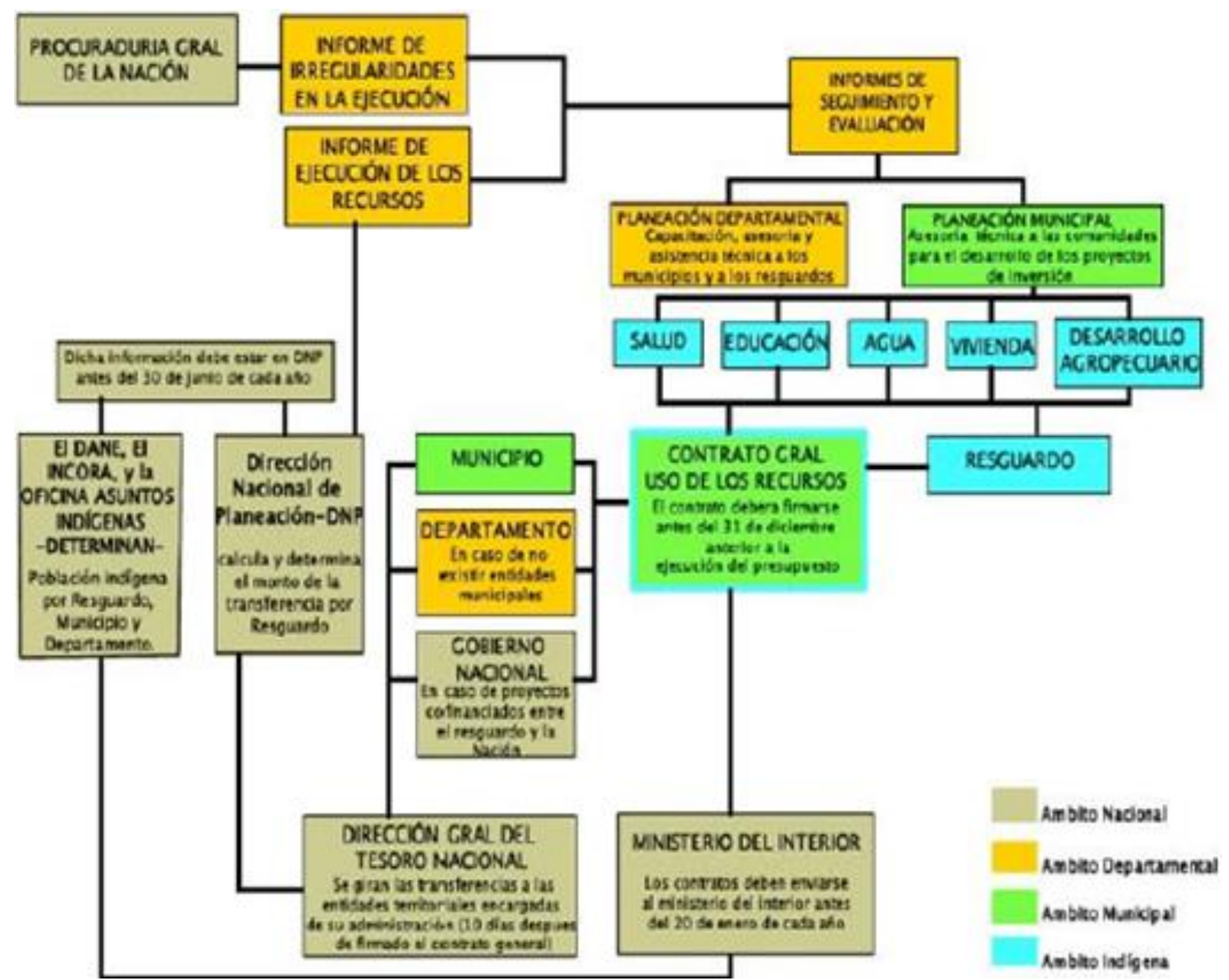

Figura 12 Diagrama de procedimiento para la ejecución y seguimiento de los recursos del SGP para el caso indígena. (Tomado de Duarte 2015, p. 189).

Uma vez assinado o contrato entre a prefeitura e o Conselho para a execução dos recursos do SPG, o gabinete do prefeito abre concurso público para a implementação dos projetos referidos no acordo geral. Estas ofertas são postas em movimento pelo prefeito, chamadas para estes processos de contratação de membros dos guardas e autoridades indígenas podem participar como proponentes serviços necessários.

É necessário ter em conta que esses contratos são executados para atender o objeto de cada um deles, independentemente da data de cessação do acordo para a implementação do orçamento atribuído às comunidades pelo SGP.56100De acordo disposto no artigo 89. ${ }^{\circ}$ da lei 715 de 2001, promotor da gestão desses recursos é função do escritório da Controladoria-Geral. Secretarias de planejamento departamentais são responsáveis para o acompanhamento e a avaliação dos recursos 
alocados para as comunidades; Esta avaliação tem o relatório semestral e o anual de monitoramento e avaliação da aplicação dos recursos, feita pelo prefeito ou governador, conforme o caso.

Estes relatórios devem ser realizados por cada um dos guardas que estão sob a sua jurisdição e devem ter a assinatura da autoridade da recepção, o tesoureiro e contador da entidade territorial. Depois da Secretaria de planejamento departamental desenvolve dois relatórios, um sobre a aplicação dos recursos do SPG seguindo a metodologia do DNP e outros onde surgem as alegadas irregularidades na gestão dos recursos que serão enviados para a Controladoria-Geral e o gabinete do procurador-geral.

Embora tecnicamente e legalmente diferentes estágios e o processo de implementação de recursos AESGPRI competências são definidas, a implementação destes não é clara ou comunidades, ou às autoridades da administração pública local. De acordo com o acima exposto, a refundação do Estado colombiano, com a constituição de 1991, emitiu uma série de direitos para os povos indígenas que tem entre seus pilares multiculturais, o reconhecimento da propriedade coletiva dos territórios que habita e a administração autônoma de suas tradições e costumes deles.

No entanto, as alterações legais que experimentaram o processo de descentralização do governo colombiano, para alterar a lei 60, através da lei 715 significa um revés para o que foi acordado na constituição de 1991. Desde artigos 356 e 357 amplamente definir a autonomia do governo local indígena no que diz respeito os recursos transferidos. Mas em sua implementação factual do ato 60, é possível apreciar seus limites operacionais. Limites que lidaram com o mesmo desenvolvimento legislativo da constituição de 1991, que, para este caso, tem experimentado como um grande obstáculo, a recusa do estado de estabelecimento de entidades territoriais indígenas ETIS.

Depois de mais de 20 anos as entidades territoriais indígenas - ETIS não formaram sob o argumento de que essas entidades tinham que para esperar para a emissão de uma lei orgânica de Planeamento Territorial - LOOT. No entanto, uma vez emitido o LOOT em 2011, não consta qualquer entidades territoriais indígenas - seção ETIS. A lei de 60 para a mudança de lei 715 envolveu um alterações de série no ambiente inicial de contemplações constitucional para Autonomias locais descentralizadas, incluindo indígenas.

A lei lei 715 e o 1176 representado uma restrição orçamentária, implementado em um gradual e programada de maneira para entidades 
subnacionais (incluindo municípios e reservas indígenas). Mas também para setores indígenas, lei 715 significado um duro golpe para as suas aspirações por autonomia no el101ambito da sua governação económica, se um leva em conta que forçou conselhos e autoridades indígenas para definir as despesas dos recursos recebidos por transferências nos sectores orientados do estado (saúde, educação, desenvolvimento agrário e adaptação). Ao mesmo tempo, a lei 715, exigindo o desenho de "Projetos", em vez de "Perfis de projeto" (ato 60), forçado autoridades indígenas para imergir-se totalmente a racionalidade do planejamento de projetos. (DUARTE, 2015, P. 214)

De acordo com Duarte (2015) um dos principais problemas do atual sistema geral de participação para as comunidades indígenas, é instalado inicialmente em um nível jurídicodiscursivo, na medida em que cada sistema agente interpreta a lei e as fases dos processos operacionais de acordo com um sistema conceitual e contextual bastante diferente.

Não só a dicotomia estado indígena, mas várias dependências no interior do estado envolvido no processo de responder e cada lógica e diferentes funcionalidades. Esta situação é parte do que chamamos nesta investigação como fricção interétnica, entrando em colisão divergentes visões corporativas de gestão e administração pública local de territórios indígenas coletivas.

Como veremos no caso da gestão e da administração pública nos territórios indígenas do município de Toribío, que discutiremos no próximo capítulo desta dissertação, fricção interétnica presente na colisão de interpretações jurídicas e discursivas situa-se nas questões que fazem os povos indígenas de Cauca, a validade jurídica dos "manuais operacionais" construído pela direção nacional de planeamento, onde, de acordo com os testes indianos, o DNP iria ser atribuindo funções de legislador para exceder suas interpretações da lei.

No caso estudado nesta pesquisa, uma outra questão importante neste momento é sobre quantificação demográfica dos povos indígenas, como recorrentes figuras que lidar com o dinamarquês e registros dos mesmos conselhos em relação ao número de povos indígenas que compõem cada reserva não coincidem. O que tem levado aos conselhos de acusar o estado de não reconhecer o crescimento demográfico das comunidades e as instituições do estado a considerar 
sistemas fiáveis de registo indiano, tão pouco e com uma tendência manifestos para inflar os números para receber mais recursos.

De acordo com o quadro jurídico da operação ou a execução do direito dos povos indígenas para governar seus territórios de acordo com seu uso e costumes, ligando para o sistema geral de participação a partir do orçamento nacional étnica de alocação especial dado aos territórios indígenas, o Estado colombiano exerce uma tutela rígida na administração dos territórios indígenas através de várias instituições públicas e esquemas tecnocráticas que ameaçam ou limitar as possibilidades reais de governação autónoma indígena, como veremos na experiência dos guardas de Toribío, Tacueyó e San Francisco, na administração e governação dos territórios indígenas do município de Toribío para analisar no próximo capítulo. 


\section{CAPÍTULO 3 - GOVERNO INDÍGENA NO MUNICÍPIO DE TORIBIO, NORTE DEL CAUCA, COLÔMBIA}

O termo de governança ultimamente está sendo usado para significar a capacidade de nossas comunidades e autoridades para definir e controlar o conjunto de atividades que desenvolvemos regionais, zonais e locais. Pablo Tatai, líder do Conselho Regional do CRIC-

Cauca $^{10}$.

Depois de ter feito uma abordagem para a historicidade das relações interétnicas do povo da nasa, descreva o regime jurídico e administrativo do processo de descentralização e modernização política neoliberal que faz parte da implementação dos direitos culturais diferenciados relacionados ao território indígena reconhecido pela reforma constitucional multicultural do Estado colombiano.

Neste terceiro e último capítulo, me aproximarei das muralhas de San Francisco, Toribío e Tacueyó experiência na administração e governação dos territórios indígenas Toribío e sua ligação com o sistema geral de participation-(SGP). Para começar a seguirão, inicialmente, para contextualizar em geral ao município de conselhos e Toribío, apresentando alguns dados demográficos fornecidos pelo último censo realizado pelo Estado colombiano em 2005, em 2013.

Vou continuar a descrever a organização social e política que configurar a administração e governança local. Então mencione a formulação e o desenvolvimento do plano de guardas de Toribío, conhecido como projeto da Nasa, que é uma iniciativa de desenvolvimento comunitário que começou no início de 1980 e precedido o reconhecimento da diversidade cultural da Constituição política de colagem 1991y de guardas para GSP. Vou continuar abordando os preceitos ou tulpas constituintes do processo organizacional indígena nasa do qual estão envolvidos na administração e na gestão pública local, o município de Toribío.

Abordarei finalmente os equívocos e contradições que eu considero fricções interétnicas entre a proposta de sua Assembleia pela nasa indígena que busca a exequibilidade e a reivindicação dos indígena administração autônoma de territórios relacionados diferenciais cultural os direitos coletivos e os processos de descentralização local da corte neoliberal promoveram pelo Estado.

\footnotetext{
10 TATTAY, Paul. Construção do próprio poder do movimento indígena de cauca, na nossa vida tem sido nossa luta, resistência e memória em Cauca indígena. Bogotá: Centro de Memoria histórica, 2012.
} 
Por que focar o testemunho fornecido pela nasa Ezequiel Vitonás líder eleito duas vezes como prefeito de Toribío, para o período 2012-2015 e Gilberto Muñoz antigos municípios de prefeito de Toribío e Miranda, com uma elevada percentagem dos indígenas da nasa e agora candidato para as eleições para o cargo de governador do departamento de Cauca, pelo movimento indígena alternativo e Social (MAIS).

Bem como a opinião expressado por outros funcionários da administração municipal de Toribío, que como o prefeito e o ex-prefeito estão ou estiveram no dilema entre o seu papel como funcionários do estado e suas raízes de comunidade em líderes e autoridades tradicionais. É pertinente mencionar que devido à limitação de tempo para processar as informações obtidas durante o trabalho de campo foi decidido concentrar este relatório final sobre o depoimento fornecido por aqueles que estiveram na situação de funcionário público e líder comunitário ou autoridade tradicional.

Agora que estas nos deram informações explícitas para revelar as fricções interétnicas na gestão e administração pública local, no município de Toribío. As informações obtidas em outras entrevistas e grupos de discussão serão usadas como material suplementar de pesquisa.

\subsection{Contextualização do município de Toribío, Cauca, Colômbia}

O município de Toribío situa-se nas encostas ocidentais dos Andes centrais, a uma altitude variando de $1.800 \mathrm{~m}$ a 4.150 metros em Páramo de Santo Domingo, a nordeste do departamento de Cauca, no sul da Colômbia. Tem uma extensão territorial de 51,967 hectares, representando 1,7\% da 3.050.900 hectares do território do departamento de Cauca. De acordo com a direção de assuntos indígenas do Ministério do interior enfermagem 2070 guardas que compõem a área total do território municipal, são viés indígena de origem colonial e 9018 hectares protegidos de Toribío, 15,064 hectares San Francisco e Tacueyó 27.885.

Tem uma temperatura média de $19^{\circ} \mathrm{C}$ que varia nos diferentes pisos térmicos que proporcionam uma paisagem natural caracteriza-se por ecossistemas em uma variedade de climas, variando de clima temperado a frio, até chegar a rastelando, que permite que você acomodar uma grande variedade de flora e fauna. Um dos maiores potenciais de água do país, representado em um conjunto de lagoas e nascimentos de água dos rios que são afluentes do Rio Cauca, concentrando-se alguns dos maiores rios do país. Geograficamente faz fronteira a leste com o departamento de Huila, Tolima e pertence ao município de Páez, pelo oeste com o município de 
Caloto, ao norte com o município de Corinto, ao sul com o município de Jambaló e a uma distância de 123 km da capital do departamento de Cauca Popayan e 83 quilômetros da cidade de Cali. Sua divisão territorial é coloniais guardas em Tacueyó, Toribío e San Francisco, que, por sua vez, são apresentados como distritos em que se encontram incluíram os 66 assentamentos em que subdivide o território.

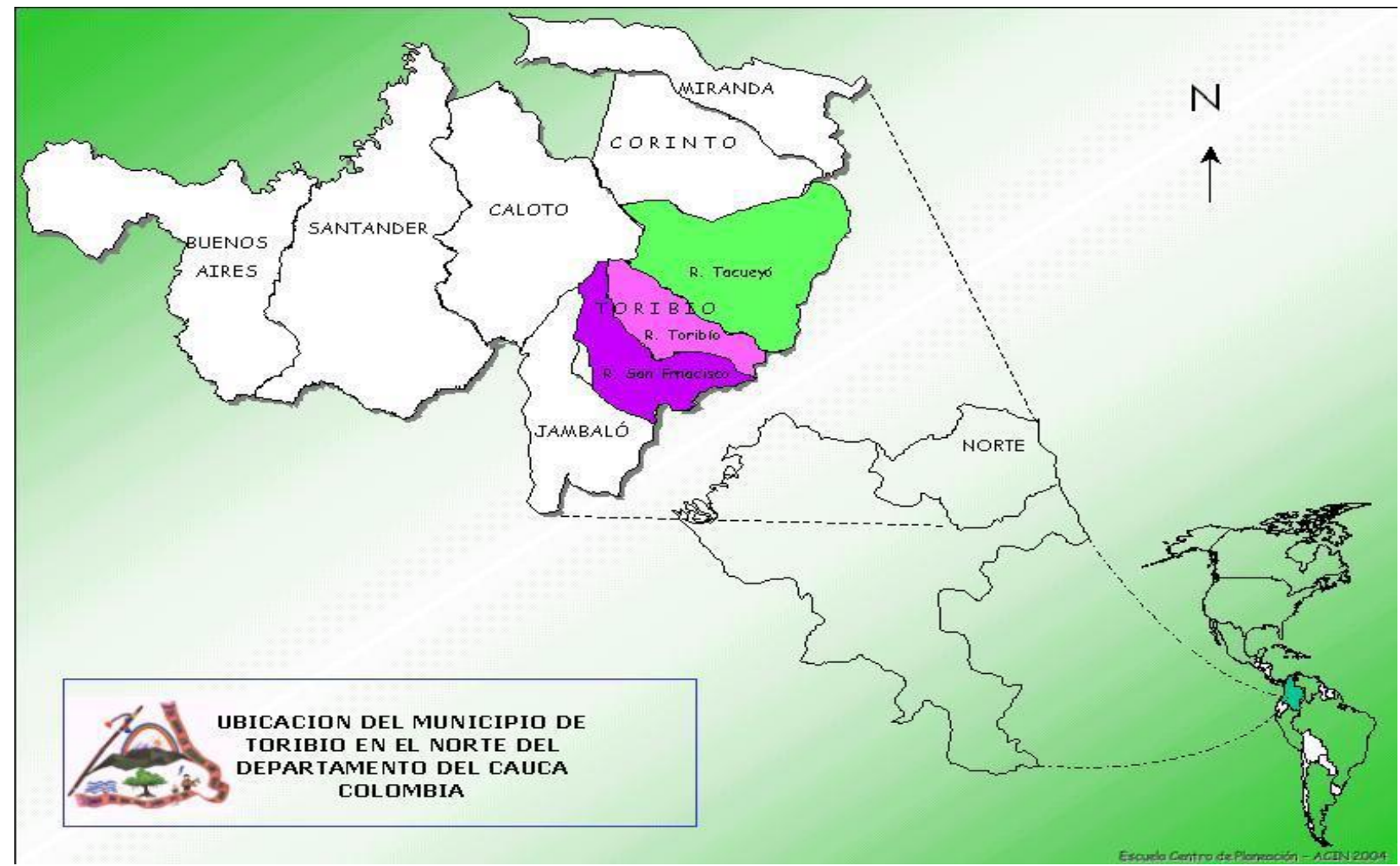

Figura 13 Fuente: Plan de desarrollo Municipal de Toribío (200-2011).

\subsection{Um abordagem demográfica e estatística para o município de Toribío}

De acordo com o último censo da população do dinamarquês em 2005, o município de Toribío tinha 25,093 habitantes, dos quais $51,2 \%$ são do sexo masculino e 48,8 por cento é mulheres. $\mathrm{O}$ gráfico a seguir representa a participação da população por grupos etários de cinco anos onde há provas de que o grupo entre 5 e 9 anos de idade constitui uma grande porcentagem $(14,4 \%)$ da população de pirâmide, seguido pela idade entre $0-4$ anos $(13,7 \%)$ e 10 a 14 anos $(13,1 \%)$, respectivamente. De acordo com figuras projetadas pelo dinamarquês, de 30 de junho de 2013, o município teria 28,561 habitantes, dos quais 52,2\% homens e $47,8 \%$ são mulheres. $96 \%$ da população vive na zona rural e os restantes $4 \%$ na capital. 


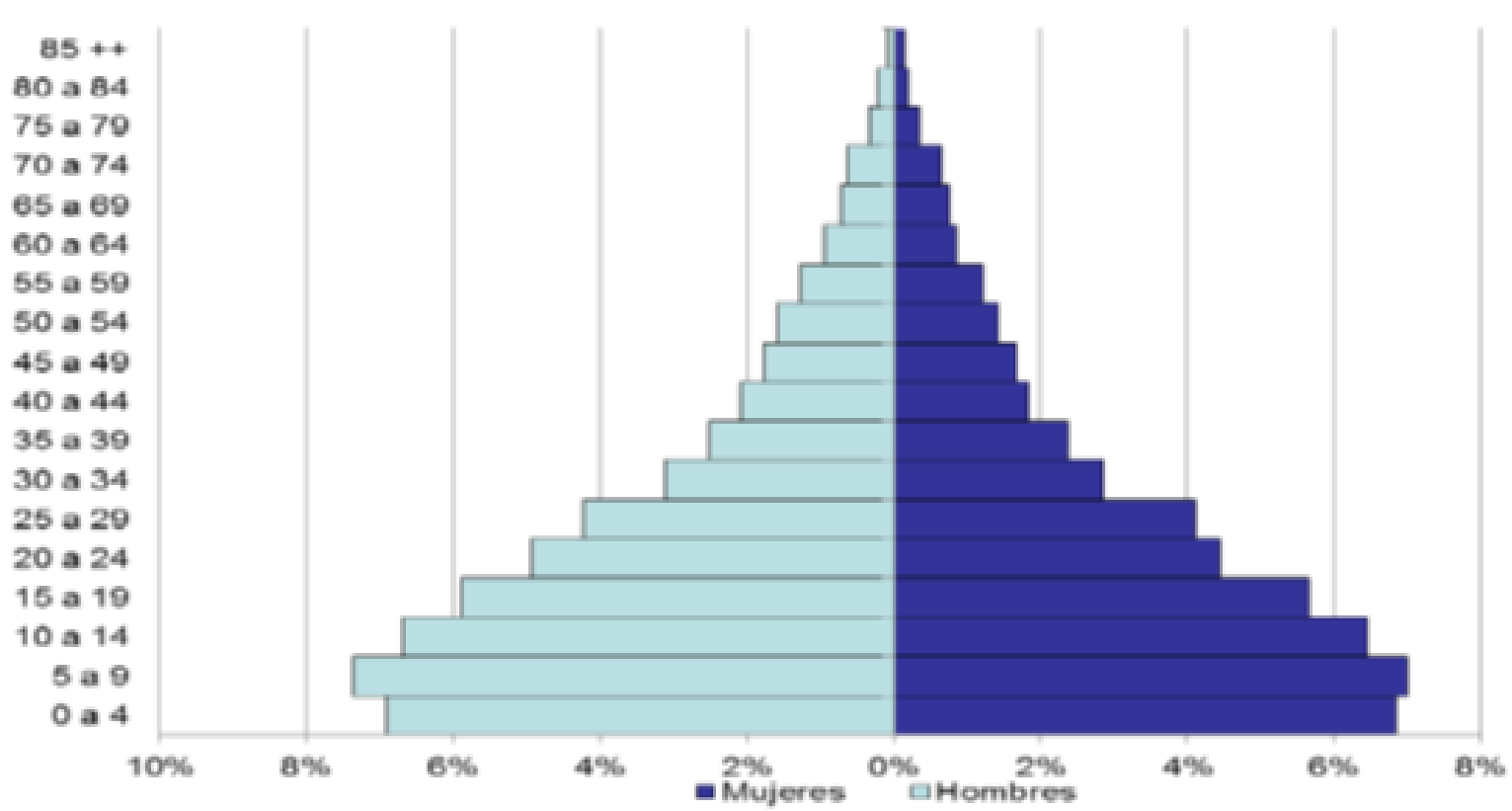

Figura 14 Estructura de la poblacion por edad y sexo, municipio de Toribio 2005 (DANE, 2005).

As principais atividades econômicas são a agricultura de $85,7 \%$ e gado, 9,4\%; em menor medida, o peixe é de 2,5\%. Por outro lado, 18,1\% dos estabelecimentos que se dedicam à indústria; $62,0 \%$ ao comércio; $19,3 \%$ 0,6\% para outras atividades e serviços. Estima-se que a produção agrícola, exceto o café é 2,736 toneladas, tornando-se uma despensa agrícola que fornece produtos para os mercados regionais em Santander de Quilichao, Corinto e Cali. No entanto, citando a agricultura como a principal atividade econômica do município é importante mencionar que "70\% do total do território é floresta vocação e apenas $30 \%$ é usado para atividades agrícolas e 50\% do território tem um alto grau de erosão." (Lei n. ${ }^{\circ} 11$, Assembléia Geral "projeto da Nasa, CECIDIC, em 29 e 30 de dezembro de 2010).

Em termos de serviços sociais de aqueduto, esgotos e eletricidade, de acordo com o mesmo censo 2005 dinamarquês, cobertura urbana e rural do aqueduto foi $94.12 \%$ e 64,4\%, respectivamente, cobertura de saneamento urbano foi de $92,5 \%$ e $12,4 \%$ rurais, urbanas e cobertura de energia rural foi de $96 \%$ e $68,3 \%$, respectivamente.

\subsubsection{Pertenceu étnica da população}

As pessoas que a nasa, de acordo com o último censo de 2005 é composta por 186,178 pessoas, dos quais $51 \%$ são homens (94,971 pessoas) e 49\% mulheres (91,207 pessoas). Concentrou-se nos departamentos de Cauca, onde habita $88.6 \%$ da população (164,973 pessoas), 
o Valle del Cauca, com 3,8\% (7005 pessoas) e Putumayo com 1,7\% (3190 pessoas). Esses três departamentos concentrar 94,1\% da população desta cidade. Eles também são em menor percentagem nos departamentos de Tolima, Huila e Caquetá. Como em alguns centros urbanos nas grandes cidades.

A Nasa representam 13,4\% da população indígena da Colômbia. (DANE, 2005). Principalmente a população do município de Toribio é automaticamente reconhecido como indígenas, no censo de 2005 96\% disse fazer parte do grupo étnico ou povo da nasa e os restantes 4\% fazem parte de outros povos indígenas, especialmente mizak ou são reconhecidos como mestiços. Censo atualizado abril de 2013, de três conselhos de Toribio, Tacueyo e San Francisco exigem que a população é 32.676, dos quais 16.442 (50,3\%) são homens e 16.234 mulheres (49,7\%); assim, apresentando grandes diferenças entre o recenseamento dos Cabildos e projeções do DANE, conforme mostrado na tabela 1. Sendo uma das principais diferenças existentes na implementação da relação dos povos indígenas ao sistema geral de participação. Tabela 1. Município de Toribio: resultados das projeções Cabildos censo e DANE para 2013.

\begin{tabular}{|l|l|l|r|l|}
\hline Sexo & $\begin{array}{l}\text { Proyecciones } \\
\text { del DANE a } \\
\text { Junio 30 del } \\
2013\end{array}$ & $\begin{array}{l}\text { Censo de los } \\
\text { tres Cabildos, } \\
\text { Toribio, Tacueyó } \\
\text { y San Francisco a } \\
\text { abril 24 del 2013 }\end{array}$ & $\begin{array}{l}\text { Diferenciales } \\
\text { absolutos de } \\
\text { población } \\
\text { de población } \\
\text { entre Censo } \\
\text { Cabildos y } \\
\text { proyecciones } \\
\text { DANE }\end{array}$ \\
\hline Hombres & 14908 & 16442 & 1534 & 10,3 \\
\hline Mujeres & 13653 & 16234 & 2581 & 18,9 \\
\hline Total & 28561 & 32676 & 4115 & 14,4 \\
\hline
\end{tabular}

Figura 15 Censo del Cabildo 2013.

Tabela ${ }^{\circ} 2$ apresenta a população correspondente para cada reserva, bem como o número de famílias e o número de pessoas por agregado familiar. O recebimento de Tacueyo é que tem a maior população com 14,544 habitantes, 4,033 domicílios e uma média de 3,6 pessoas por agregado familiar.

O recebimento de Toribío tem uma população de 10,127 pessoas, 1.556 domicílios e uma média de 6,5 pessoas por agregado familiar, um indicador que mostra que este abrigo famílias são bastante numerosos. Finalmente, a guarda de San Francisco tem 8,005 habitantes e 2,129 famílias e uma média de 3,8 pessoas por agregado. 
Cuadro 2. Población por sexo resguardos indígenas de Tacueyó, Toribío y San Francisco, Municipio de Toribío-2013.

\begin{tabular}{|l|r|r|r|r|r|}
\hline \multicolumn{5}{|c|}{ Municipio de Toribío: principales resultados de los Censos de Cabildos } \\
\hline Resguardo & Familias/hogares & Personas & Hombres & Mujeres & $\begin{array}{c}\text { Número de } \\
\text { personas por } \\
\text { hogar }\end{array}$ \\
\hline Tacueyó & 4033 & 14544 & 7341 & 7203 & 3.6 \\
\hline Toribio & 1556 & 10127 & 5033 & 5094 & 6.5 \\
\hline San Francisco & 2129 & 8005 & 4068 & 3937 & 3.8 \\
\hline Total municipio & 7718 & 32676 & 16442 & 16234 & 4.2 \\
\hline
\end{tabular}

Figura 16 Municipio de Toribío: principales resultados de los Censos de Cabildos.

En la Gráfica 2 se presenta la estructura de población del resguardo indígena de Toribío para el año 2013, distribuida por sexo y grupos quinquenales; es una gráfica con poca participación de las edades entre los 0 y los 9 años y una mayor participación de las edades entre los 10 y 19 años, lo que demuestra que es una población relativamente joven según el alto porcentaje.

Alguns indicadores sócio-demográficos dos três guardas do município de Toribio, de acordo com seus próprios recenseamentos ao ano 2013; pode ser encontrado na tabela $\mathrm{n}^{\mathrm{o}} 3$ as figuras evidenciado essa dependência demografica15 relação à população indígena do recebimento de Toribio é 0,66 , o que significa que para cada 100 pessoas indígenas em idade produtiva, 66 foram encontrados em idade dependente. Isto tem uma relação porque Toribio, o número de pessoas por agregado familiar é de 6,5; Essa dependência demográfica é distribuída em 0,58 (menores de 15 anos) na dependência juvenil e 0,08 (mais de 64 anos) é senil. Na população indígena nacional, a taxa de dependência demográfica é muito maior, a proporção é de 0,81 (DANE, 2005). 


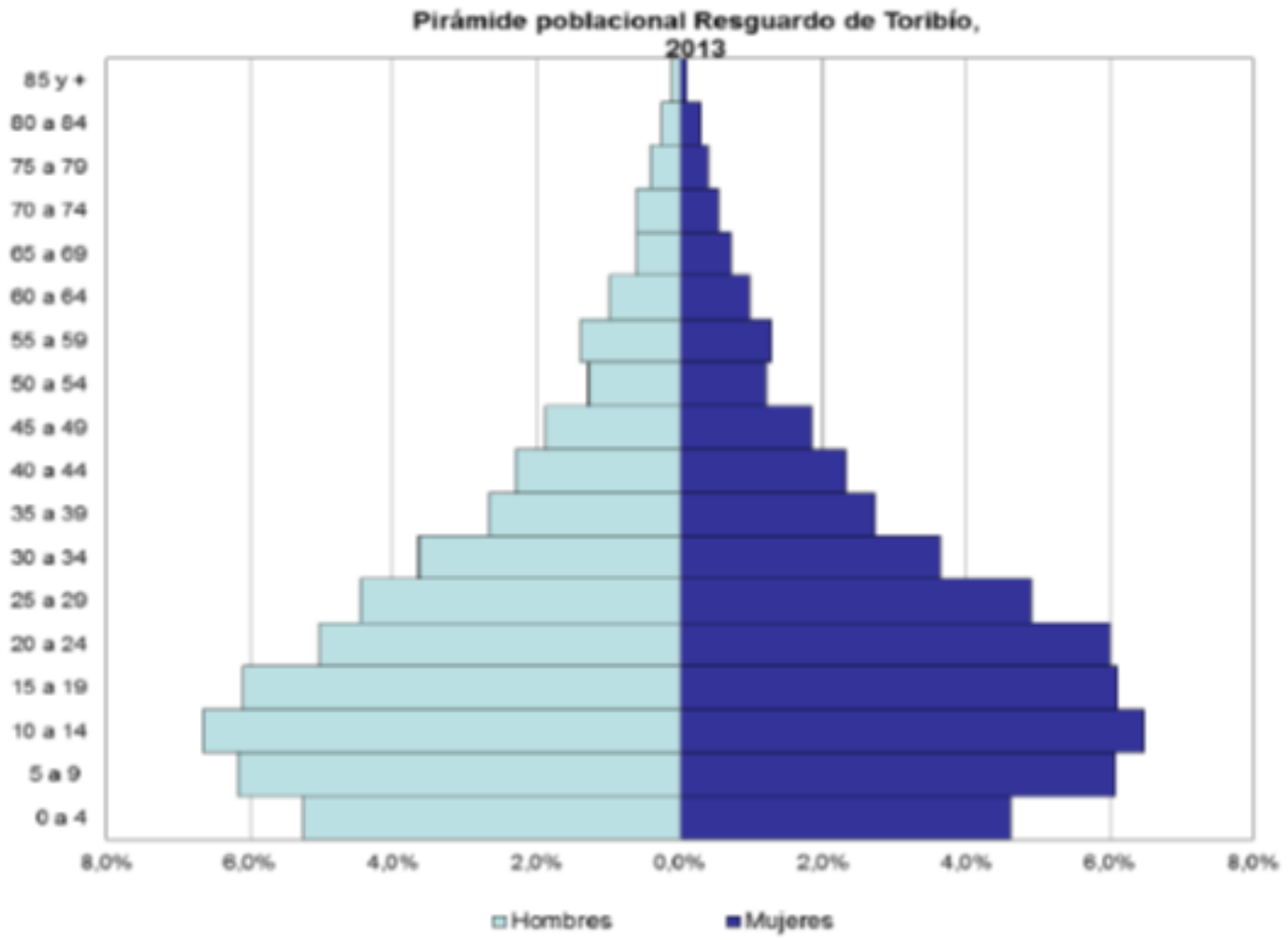

Figura 17 Estructura de poblacion por edad y sexo (Resguardos Indigenas de Toribio 2013.

\begin{tabular}{|l|l|l|l|l|l|}
\hline $\begin{array}{l}\text { Resguardos Municipio de } \\
\text { Toribio }\end{array}$ & $\begin{array}{l}\text { Tasa } \\
\text { dependencia } \\
\text { Juvenil }\end{array}$ & $\begin{array}{l}\text { Tasa } \\
\text { dependencia } \\
\text { Senil }\end{array}$ & $\begin{array}{l}\text { Tasa } \\
\text { dependencia } \\
\text { Total }\end{array}$ & $\begin{array}{l}\text { Razón de } \\
\text { Hijos*mujer } \\
\text { en edad } \\
\text { fértil }\end{array}$ & $\begin{array}{l}\text { lindice de } \\
\text { Masculinidad } \\
\text { Total }\end{array}$ \\
\hline Resguardo Tacueyó & 0,6 & 0,05 & 0,65 & 0,38 & 1,02 \\
\hline Resguardo Toribí & 0,58 & 0,08 & 0,66 & 0,36 & 0,99 \\
\hline Resguardo San Francisco & 0,48 & 0,08 & 0,55 & 0,28 & 1,03 \\
\hline
\end{tabular}

Figura 18 Indicadores sociodemográficos de los resguardos del municipio de Toribío-2013 (Censo Cabildo Nasa de Toribio, 2013).

\subsection{Organização social e política do município de Toribío}

A organização social e política do município de Toribío é configurada a partir da justaposição de instituições, conceitos e práticas de natureza diferente e muitas vezes divergentes, mas que estão em constante interação de relações interétnicas do estado e os povos indígenas na administração e governança local. Dualidade representada no município como uma entidade territorial da administração pública, com base em um centralista natureza administrativa ordem 
política liderada pelo prefeito e vereadores. E os guardas como entidades territoriais indígenas de caráter especial e transitória precederam pelo capítulo como autoridade tradicional, bem como outras organizações indígenas que respondem ao coletivos critérios culturais, políticos e territoriais como associação de cabildos municipal e regional.

Organizações e instituições através da quais os povos indígenas para governar seu território das formas tradicionais, o que corresponde a uma visão de mundo da vida, com base na participação direta nos assuntos coletivos que permite um controlo comunitário do território e a produção coletiva de bens. Gerenciando a recuperar, reinventar e preservar suas tradições e costumes, para reforçar a linguística e aspectos sócio-culturais que são encadeados e jogados nas práticas comunitárias e nas manifestações festivas ligados às formas de ser e sentir.

Essa dualidade é que as chamadas de José María Rojas (1993) pesquisador da bipolaridade do poder local. A este respeito, a administração e a gestão pública do município de Toribío tem um caráter dual que fazem parte de um sistema interétnico que configura uma totalidade sincrética, na situação de coexistência de diferentes práticas culturais, dentro de um espaço territorial, "entre duas populações dialeticamente unificada através de interesses diametralmente opostos, mas paradoxalmente interdependentes" (OLIVEIRA CARDOSO, 1981 p. 26). Encontrado, por um lado, as práticas culturais que permitem a regulação e administração do território, do material e a parte espiritual do povo da nasa; e por outro lado, instituições, práticas e sistemas de intermediação e contato que visa implementar políticas de carácter geral ou específico do estado.

Essa dualidade no domínio da administração pública local para adquirir uma relevância particular na Colômbia desde a reforma constitucional multicultural de 1991 concedido direitos culturais territoriais indígenas que lhe permitam governar independentemente seus territórios de acordo com suas tradições e costumes.

\subsubsection{As instituições Estatal municipais}

El da administração pública como entidade territorial fundamental da divisão políticoadministrativa do estado, política, fiscal e administrativa autonomia dentro dos limites, apontandolhe a constituição e as leis da República. Nos termos do artigo 311. O da Constituição e a lei 136, de 1994, tem como principais funções a prestação de serviços públicos que determina a lei 715 de 2001 em relação às competências em áreas como educação, saúde e saneamento básico, entre outros fins gerais entre a nação e as entidades territoriais. 
Da mesma forma, é até obras que demanda local o progresso, ordenando o desenvolvimento do seu território, promover a participação da Comunidade, melhorar as condições sociais e culturais de seus habitantes e desenvolver iniciativas que visam fornecer soluções para as necessidades mais prementes da população. Para alcançar a conformidade com os objetivos estabelecidos no plano de desenvolvimento da administração municipal na cabeça da prefeito se orgulha de uma equipe de governo que faz parte das diferentes agências administrativas proposta do governo municipal que operativizan. Em cada município há uma corporação administrativa eleita popularmente por um período de três anos, nomeado como o Conselho da cidade. Composto por não menos de sete nem mais de vinte e um Membros, conforme determinado pela lei, em conformidade com a respectiva população.

Seus atos administrativos são denominados acordos municipais e através delas regulam o desempenho da administração local em matéria de carácter geral. É a responsabilidade destas entidades regulam as funções e eficiente prestação de serviços realizados pelo município, adotar planos apropriados e programas de desenvolvimento social, econômico e de obras públicas, determinar a estrutura de gestão e as funções de suas dependências, escalas de remuneração correspondente às diferentes categorias de emprego entre ou não.

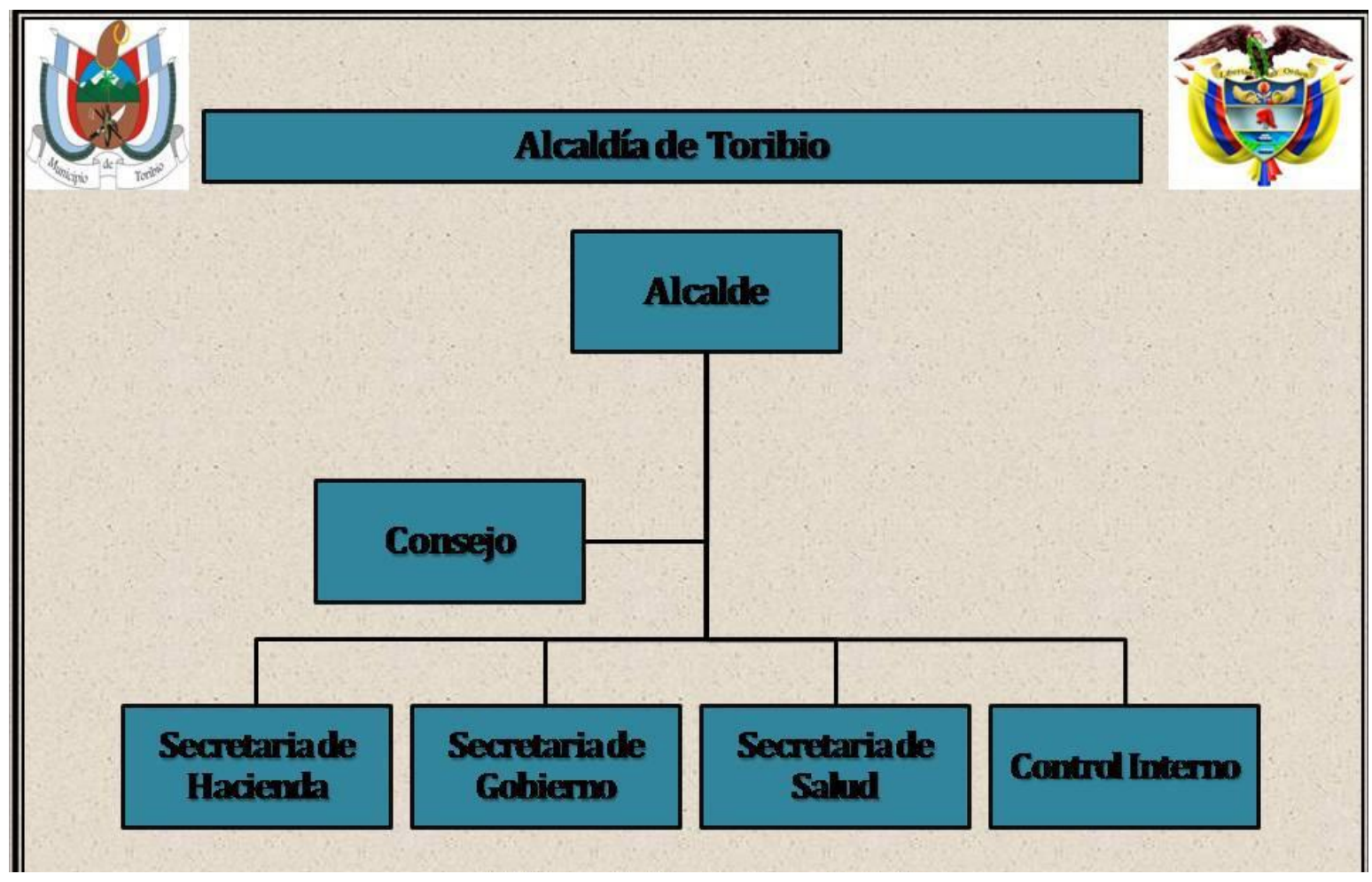

Figura 19 Organigrama de algunas de las dependencias de la administración pública municipal de Toribío. 


\subsubsection{Institucional indígena comunitária}

Existente duas instituições comunitárias gerenciar e governam os territórios indígenas, de acordo com os usos e costumes das comunidades, apesar de ser instituições decorrentes do período colonial, os povos indígenas têm feito uso dele, daquele período até hoje, para afirmar a sua autonomia e defender as suas identidades culturais e territórios. Agora que estas figuras políticas administrativas forneceu lês pelo menos nos direitos políticos coletiva de domínio jurídico relativas à propriedade de seu território ancestral, como um espaço legítimo para recriar e preservar as tradições culturais.

Como já mencionado nos parágrafos anteriores a constituição de reservas e cabildos corresponde a um período de transição desde a conquista colonial, no século XVI e representam uma importante mudança nas relações da coroa espanhola com povos indígenas, o que implica o reconhecimento do direito dos povos indígenas têm um governo próprio que responde a sua identidade cultural.

Apesar das declarações e intenções remova o guarda e o cabildo indígena durante a República, para integrar os indígenas à identidade nacional sob a asimilacionista do paradigma e sua terra para o mercado de imóveis de propriedade privada. Guardas e conselhos ao município de Toribío nasa não sucumbiram à empresa colonizar na República durante o século XIX e primeira metade do século XX, apesar de seu território original tinha sido grandemente reduzido pela produção econômica da fazenda de Murua. Em 1859, o soberano estado de Cauca através de lei 90 reconhece os conselhos e resguardos indígenas e emitiu orientações para a sua constituição.

Mais tarde, sob o pretexto da constituição de 1886 cortar fortemente centralista em 1890 é emitida 80 lei que reconhece as cabildos e abrigada como instituições indígenas da autonomia de seus territórios. Isto seria válido para mais de 100 anos até que a constituição de 1991, que considera as cabildos indígenas entidades públicas de natureza especial vinculados ao sistema de administração pública, através da descentralização. E entidades territoriais autónomas de guardas com personalidade jurídica, seu próprio patrimônio, com links para o orçamento nacional através do sistema geral de participação-SPG, autonomia administrativa e competência especial indígena.

Tanto as reservas e cabildos como autoridade destas unidades territoriais são reconhecidos pelo Estado como as entidades públicas de natureza especial, com autonomia para gerenciar seus 
territórios, fazer justiça, legislar e gerenciar seus recursos e aqueles transferidos pela nação, de acordo com suas tradições e costumes.

\subsubsection{Os resguardos indígenas do município de Toribío}

Os resguardos como divisão político administrativa do território do município de Toribío consiste de guardas em Tacueyó San Francisco e Toribío de origem colonial. No início do século XVIII em 1700 cacique Quilo e músicos pediram a Real audiência de Quito que no território que habitam é concedido para as pessoas das aldeias de Toribío, Tacueyó e San Francisco. Assegurar no seu pedido que essas terras não sejam livres de "Propriedade", e que não foi reconhecido o outro proprietário do que os chefes, mas querendo fazer a posse dos povos indígenas no futuro atende o rei como autoridade competente para conceder títulos ou papéis que reconhece a posse de seu território.

Antecipando-se ao longo do tempo que os colonos planeiam para tomar o seu território. Solicita, pois, que o alinhamento de suas terras é feito por um Comissário da audiência real. Quilo e aplicativo básico destaca-se o princípio jurídico de direito indígena ancestral que evoca como proprietário e primeiros habitantes dos territórios ocupados. O propósito do Chyle e músicos obter reconhecimento da titularidade coletiva do território dos seus povos foi bem sucedido e as autoridades coloniais enviaram um funcionário da plateia real de Quito para que toma lugar alinderamiento. Apesar da miríade de circunstâncias adversas à sua existência ao longo da história descrita no primeiro capítulo desta dissertação, o trabalho da nasa conseguiram recuperar e consolidar a territorialidade que faz parte destes três guardas.

Atualmente os territórios coletivos dos territórios indígenas que compõem o município de Toribío dividem-se em 66 trilhas, cada uma dessas unidades territoriales se subdivididos em parcelas ou fazendas que são estudos por famílias; local onde vivem e trabalham juntos, várias famílias, comunidade terras gerido pela Câmara Municipal e trabalhou por todas as famílias da guarda para se beneficiar das iniciativas comunitárias e instalações inteiras da produção comunitária de bens de consumo.

Eles também são áreas de reserva ambiental onde as lacunas e água olhos, sagrado sites e o Páramo de Santo Domingo. Eles são territórios auto-regulação coletivamente, através de leis e regulamentos que são acordados comunitariamente, cujo cumprimento é controlado por todos, esta auto-regulação é a par com os processos organizacionais. 89 da lei de 1890, "por que ele determina 
a maneira como eles devem ser regidos os selvagens que são reduzidos a civilizada vida", através da tarefa de civilizador da igreja, para ser menores que devem ser culturalmente integrados a sociedade dominante, que era a peça central da legislação indígena na Colômbia para mais de um século Renovo a base jurídica do abrigo como uma declaração política e social da administração da entidade territorial e territórios indígenas. Definir a organização interna da recepção, seus objetivos e sua relação com as autoridades nacionais e regionais.

Foi estabelecido na Constituição política de 1991 que as terras de abrigo são de propriedade coletiva, não alienável, imprescritíveis e impenhorável (artigos 63 e 329 da Constituição), também decreto 2164 de 1995, que refere-se à "prestação e titulação de terras para as comunidades indígenas para a criação, reestruturação, extensão e renovação dos territórios indígenas no território nacional" define esta última como:

Uma instituição sócio-política e jurídica de caráter especial, formado por uma ou mais comunidades indígenas, que beneficia as garantias da propriedade privada, com um título coletivo possuem seu território e aplicar para o tratamento desta e de sua vida interior por uma organização autônoma abrangida pela jurisdição indígena e seu próprio sistema de regulamentação (artigo 21).

Regulamentos da reserva indígena consiste dos seguintes elementos básicos: a) um território definido, b) um título registrado a propriedade comunitária, c) uma ou várias comunidades que se identificam como indígena, d) uma organização interna que rege-se pelo seu próprio regulamento interno.

Abordando essa definição, ambos de origem colonial, como um novo guardas formados pelo Instituto Colombiano de reforma agrária - INCORA - ou velhos guardas. A única diferença é que o antigo tem sua origem e fundamento legal em Real ID, doação, Merced ou decreto emitido em período republicano ou outro instrumento jurídico com base na legislação promulgada antes de 1961; Enquanto este último é criado através de uma resolução emitida pelo Conselho de administração do INCORA.

Ambos os documentos têm a capacidade de certificar a guarda legal 114del (departamento de planeamento nacional, da Colômbia, 2002, p.110). Os guardas do município de Toribío como entidades territoriais transitórias de natureza especial com um território de propriedade coletiva de 
origem reconhecida pelo Ministério do interior através de seu escritório de assuntos étnicos e colonial. Eles são vinculado regime geral de participação-GSP, tem autonomia para gerenciar seus territórios, fazer justiça, legislar e gerenciar seus recursos e aqueles transferidos pela nação, de acordo com suas tradições e costumes.

\subsubsection{Conselhos dos povos indígenas do município de Toribío}

Foi atribuído um número de funções relacionadas com o regulamento interno das relações das comunidades e sua relação com o andaime político administrativo da empresa colonial espanhola na nova granada tornar-se os cabildos como a estrutura organizacional da administração e o governo dos territórios indígenas. Pesquisador de povos indígenas para a nasa Adonias Perdomo (2005),

Colonização espanhola tentou organizar nossos ancestrais à semelhança das jurisdições municipais espanholas, introduzindo um Conselho de prefeitos e comissários responsáveis pela Justiça [...] também tinham o trabalho de administradores de Royal, xerife, que teve que dar conta dos recursos fiscais, a direção do castigo e um governador que substituiria os chefes (Adonias Perdomo, 2005, p. 30).

Atividades ou obrigações a cumprir durante o período colonial incluem a garantia o assentamento estável dos povos indígenas em territórios do recibo, cobrança de impostos para o pagamento coletivo para a coroa, o recenseamento da população, a divisão e a alocação de territoriais indígenas e manipulação ou resolução de conflitos internos dos membros da Comunidade.

Também as cabildos eram os intermediários entre seus povos e a sociedade colonial de vinculação. Durante a República no século XIX as cabildos foram perseguidas ou cooptadas pelos interesses dos militares, proprietário de terras e políticos que fez usam destas instituições para alcançar seus objetivos. Como mencionado acima os conselhos também foram reconhecidos como entidades públicas especiais pela lei 89 de 1890, que prevê que:

Por todo o lado que é um viés para os povos indígenas, haverá um pequeno conselho nomeado em conformidade com seus costumes. O período de duração do presente capítulo será de um ano, a partir de 1 de janeiro a 31 de dezembro. Para tomar posse de seus cargos não necessário membros do 
Cabildo de outra formalidade, a ser reconhecida pelo viés perante o Conselho cessante e na presença do prefeito do distrito (artigo 3).

De acordo com o disposto neste ley16, em cada abrigo devem ser eleitos anualmente pelos membros da guarda um cabildo (artigo 3). Este Conselho foi atribuído um número de funções cívicas e judiciais como punição de pequenos crimes (delitos contra a moral) realização de um recenseamento anual da população e os títulos de terra de guarda de registro (inventário) perante um notário público (artigos 5 e 7).

Sua função principal, no entanto, foi o prêmio dos direitos de terra do usufruto para moradores (famílias), bem como a supervisão de todas as questões relacionadas a 63 com a posse da terra, incluindo a mediação em litígios sobre este assunto (artigo 7:3). Durante a primeira metade do século XX e algumas décadas depois as cabildos foram largamente cooptadas pelas pressões dos grandes proprietários rurais e autoridades políticas da região. Para Pablo Tatay fundador do índio o Conselho Regional de Cauca-abri, aquando da formação desta organização em 1971, alguns conselhos acompanhado a luta de terrajeros e moradores indígenas para a recuperação de suas terras.

A maioria dos conselhos foram a serviço da igreja, políticos ou proprietários de terra e foram muitos, mesmo contra os recuperadores que apelidados de "roubo de terras". No entanto, havia consciência pelas comunidades indígenas do papel histórico desempenhado pelos conselhos para defender suas reservas das tentativas de divisão ou de dissolução. Por que as lutas da década de 1970 as cabildos foram baseadas na recuperação do território ancestral, fortalecer a identidade cultural e autonomia para administrar e governar seus territórios de um instrumento organizacional que se considerava.

Inclusive, por meio de terceiro item na agenda de abri o "Fortalecimento dos Cabildos indígenas", mostra um valioso dos primeiros promotores da visão estratégica da organização, posição dentre as fontes ancestrais de resistência indígena, "governo interno", como um ponto de referência importante para a formação de seus líderes e consequente reforço da organização nascente (TATAY, 2012 p. 54).

Recuperar o conselhos para os interesses de suas comunidades foi sem dúvida uma grande conquista, pois permitiu fornecer o movimento indígena com uma base político-organizativa 
própria que lhe deu a força e a resistência contra os ataques de seus oponentes. A partir desta reorientação, conselhos são reforçados e generalizada a nível nacional, alcançando hoje, constituem a principal forma de autoridade dos povos indígenas envolvidos na liderança da organização na sua totalidade.

A importância da recuperação do capítulo como um eixo político organizacional encontrase na historicidade desta instituição como uma forma de organização e governo estabelecido e reconhecido pelos povos indígenas como um instrumento de defesa de seu território, identidade cultural e autonomia. Como Christian Gros pontos fora, com efeito, a originalidade e a eficácia do movimento indígena respondem à capacidade de uma instituição "indígenas" redistribuir mas reconhecido se originam "colonial":

Prefiro inovar para dar lugar, com a criação dos resguardos de uma organização alternativa dentro, o slogan é a partir de agora para reconstruir as cabildos (se tinha desaparecido), refazê-los, (se eles ainda existem, mas estão sob a tutela de brancos, ou interesses minoritários e hostil ao movimento), concedido novos poderes em todos os casos e colocá-los a serviço da organização e da luta pela terra. Próprio será como uma federação de conselhos e a sua assembleia geral como sua expressão direta (CHRISTIAN GROS, 1991, p. 40)

Desde as transformações constitucionais de 1991, que dão a povos indígenas diferenciados direitos culturais relacionados com a administração do coletivos territórios delimitados sob a figura dos guardas da Comunidade instituição do cabildo, o decreto 2164 de 1995 definiu-o como:

um organismo público especial, cujos membros são membros de uma comunidade indígena, eleito e reconhecido por ele, com uma organização sócio-política tradicional, cuja função é legalmente representar a Comunidade, exercer autoridade e realizar atividades que atribuiu às leis, usos, costumes e as normas internas de cada comunidade (artigo 2).

Após a constituição de 1991, o modelo organizacional do cabildo, que vem da colônia entre as comunidades indígenas na Cordilheira dos Andes e acima de tudo no departamento de Cauca e Putumayo, foi adotado pelos povos indígenas em outras regiões da Colômbia como os Llanos Orientales ou Orinoquia e Amazônia, onde não conhecido histórico relacionamento com esta 
instituição. Hoje os conselhos são uma importante entidade organizacional tradicional do movimento indígena, símbolo de autonomia e autoridade sobre os seus territórios (ver Gómez, 2000;) Gomez e Ruiz, 1997; Rappaport 2000, 2005). A essência das organizações indígenas de Cauca, que migram para os diversos conselhos que são por sua vez constituem o mais alto representante de cada autoridade comunitária.

\subsubsection{Funções e posições dos conselhos indígenas do município de Toribío}

Lós nomes que recebem, bem como as funções de cabildos variam dependendo de cada aldeia ou comunidade, mas sua estrutura tende a ser muito semelhante. No caso dos conselhos dos guardas de Toribío, Tacueyó e San Francisco, a maior autoridade encontra-se com o governador principal que tem como colaboradores para um vice-governador, um capitão principal, um capitão alternativo, um presidente e um secretário-geral; verdales Federal, um procurador, um Comissário, um tesoureiro e uma equipe jurídica de ex-governadores.

Para responder as demandas e necessidades da Comunidade foram criadas alguns grupos de trabalho, conhecidos como suporte conselhos que são: o capítulo legal, o Cabildo de família, Conselho econômico ambiental e o Cabildo de terras, estas são precedidas por seus respectivos coordenadores eleitos, como o resto do cabildantes, publicamente pela Comunidade da recepção por um período de um ano que começa tradicionalmente no dia 31 de dezembro. Os cabildantes assumir formal antes do prefeito e sua equipe, bem como a participação da Comunidade e o Conselho cessante de aqueles que recebem a "vara de controle" (haste para representar o símbolo da autoridade comunitária).

Estes cabildantes costumo levar uma vara ou bastão que os distingue como tradicionais de autoridade. Antes de ser entregue a cada um obter da Comunidade quando, bengalas são objeto de uma série de rituais pelos médicos tradicionais ou o ' Walas. Além da estrutura de gestão, a cabildo conta composta por secretários - equipe de apoio administrativo que auxiliares, um segundo tesoureiro e um contador.

Bem como consultores externos ligados às questões de desenvolvimento social Comunidade e administração público. Cada escritório tem uma série de funções específicas que é fornecidos gratuitamente, como é um serviço de comunidade não-pagos, que se baseia o compromisso de continuar com a cultura, a organização e a identidade da Nasa. Exercer um dos cargos do Conselho concede ao virar algum prestígio e reconhecimento, respeito e autoridade, 
dentro e fora da Comunidade, especialmente o cargo de governador, quem é o representante legal do cabildo.

Os três conselhos ao município de Toribío cumprem com a função de coordenar e gerem a execução dos recursos transferidos do sistema geral de participação para os guardas como entidades territoriais transitórias de natureza especial, conforme estabelecido no quadro normativo, apresentado no capítulo anterior desta dissertação com o gabinete do prefeito. O cabildo, também realizada uma série de tarefas projetado para organizar o material e espiritual controle do território, bem como assegurar o exercício do falso moralismo, a recuperação e o fortalecimento da identidade cultural e as iniciativas de avanço que buscam o bem-estar e desenvolvimento integral da Comunidade.

Do cabildo é formulado e gerenciar recursos financeiros para projetos que são apresentados ao governo e organizações não-governamentais, que vão desde iniciativas produtivas, para o financiamento de eventos tais como rituais, congressos, reuniões ou manifestações. Também planejar atividades buscando harmonizar o território através de rituais de limpeza com médicos tradicionais ou The ${ }^{e e}$ Walas e compromete-se a participar na elaboração e implementação da Comunidade educacional projeto PEC do ensino nas escolas.

Além de funções como um representante legal das diferentes instituições da comunidade local, regional, nacional e internacional. Ele atribui e delimita os lotes que corresponde a cada pessoa ou família e é também responsável pelo endereço e encontrar soluções para os conflitos que surgem entre os membros da Comunidade. Ele coordena e gerencia projetos econômicos através da gestão e execução dos recursos, bem como a organização de uma série de atividades que envolvem o trabalho coletivo das comunidades, utilizando as instituições tradicionais de comunidade trabalho dos Andes como minga ou troca de produtos sem o intermédio de dinheiro como escambo.

Organizar e celebrar rituais ou comemorações festivas relacionadas com a cosmovisão indígena, logística de coordenadas, coordenadas aspectos logísticos relacionados à participação em assembléias e marchas de protesto. Ele decreta regras internas que definem os direitos e deveres dos membros da Comunidade e punir as faltas cometidas em conformidade com a lei indígena tradicional. 
Através de reuniões e assembleias, que promove o estabelecimento de normas de conduta ou códigos morais através de comportamentos como violência doméstica, uso de drogas e álcool e os conflitos gerados pela fofoca (rumores) e ciúme dentro da Comunidade, a censura pública. Da mesma forma, o Conselho promove a adoção de práticas que procuram a unidade familiar, a prevenção da gravidez entre adolescentes, alcoolismo ou consumo de substâncias psicoativo, ligando-os a outras questões entre grupos armados. Que também participaram a recuperação e o reforço da identidade cultural por meio de práticas culturais, tais como medicina tradicional da Nasa para "harmonizar" e evitar problemas diferentes dentro de cada família e território.

Os três conselhos ao município de Toribío associam-se no projeto da Nasa, a Associação das autoridades indígenas do município constituída sob decreto 1088, de 1993, que tem condições semelhantes de entidade pública que conselhos. 


\subsection{A formulação e desenvolvimento do plano de vida comunitária dos guardas do município de Toribío}

Para parar a mobilização social desencadeada pela insatisfação com a concentração da propriedade rural e os métodos violentos usados pelos proprietários, políticos e a Igreja Católica para expropriar agricultores, indígenas e Afro-descendente de seus territórios e impulsionar o mercado interno para o desenvolvimento do capitalismo, o governo colombiano decide a emitir, em 1961, a lei 135, da reforma agrária. Que impulsionar uma série de manifestações de camponeses em todo o território nacional sob o lema da terra é que ele funciona.

Isto levou à criação em 1967 da Associação Nacional dos usuários de agricultores-ANUCorganização que protagonizaría a recuperação de grandes propriedades de terra. A nasa indígenas dos guardas do município de Toribio tornou-se parte da ANUC mas por conflitos dentro da Associação retirou e em 1971 a primeira plataforma de natureza étnica na Colômbia, o Conselho Regional indígena de Cauca abri formada com outros povos indígenas de Cauca. O abri ativamente levou a política dos programas de reforma agrária, fazer você pegar as propostas e iniciativas próprias que não se contemplam originalmente pelo governo nacional.

Neste clima de reforma agrária da década de 1960 foi oportuno para a mobilização de atores sociais como as populações indígenas que estavam em uma situação de subalternidade e terrajeria18, desde que da colônia e durante a República os territórios dessas comunidades foram despossuídos por latifundiários e a Igreja Católica, que possuía grandes extinções de terra onde os nativos trabalharam para sua subsistência.

Para este problema da expropriação dos territórios, é adicionado a violenta disputa que está sendo conduzida pelos dois partidos tradicionales-el Liberal e o conservador-da hegemonia política, que ligava o partido comunista com uma proposta de transformação da ordem estabelecida. Que divide e confronto para a nasa dos Cabildos a três ao município de Toribio, fazendo-os simpatizantes ou participar em alguns desses partidos políticos. De acordo com algumas pesquisas, o recebimento de Tacueyo pertencia aos Liberais, que de Toribio de conservadores e San Francisco tinham simpatia com o partido comunista. (Ver Delgado Hernández, 2004;) ACÍN e Nasa Cátedra UNESCO, 2002; 4)

Uma vez superar essas divisões e formaram o Conselho Regional indígena de Cauca-abri o, a violenta perseguição dos moradores indígenas que fizeram parte desta organização foi rápida, 
ao ponto de que povos indígenas não foram autorizados a recolher sozinho na ausência de representantes dos proprietários ou a polícia. Se reúnem na ausência da competente autoridade ser interpretado como subversão e ele usavam para a captura dos participantes na reunião, como fez após a Fundação do abri com seu primeiro Conselho de administração.

A oportunidade política, apresento a reforma agrária foi usada pelos indígenas para reunir e organizar. Com a experiência do envio para o terrajeria, os povos indígenas estavam envolvidos com as Asociación Nacional de Usuarios Campesinos. Já com o ANUC, um Secretariado tinha sido estabelecido para os povos indígenas como parte de sua estrutura, mas depois de uma leitura da gestão da associação e tendo em conta a situação dos povos indígenas e o contexto social nacional, o setor indígena renunciado por escrito o Secretário indiano da ordem ANUC pensar seu processo organizacional, independentemente de acordo com as necessidades e a emergência de indígena, mas aberto para apoiar os esforços do ANUC e outras organizações populares (RAMOS, 2011, P.94)

O fundador da abri no Assembly de 1971 foi realizado no município de Toribio e contou com a participação das cabildos de San Francisco, Toribio e Tacueyo. Sendo estas três guardas, um dos epicentros do processo de recuperação de terras e devido a capacidade de organização da população que iria começar a tomar forma neste território uma vida comunitária plano da plataforma estabelecida pela luta abri. Com procurou o desenvolvimento integral e social da Comunidade, a recuperação da terra dos guardas e o seu alargamento, reforçar a forma de governo e a própria precedido o cabildo, o não-pagamento de Murua, a divulgação das leis e dos direitos dos povos indígenas para impor autoridade. Bem como a recuperação e a reinvenção da sua identidade a fim de reforçar as práticas culturais da Comunidade relacionados com sua visão de mundo como povos nativos.

Foi neste território indígena, onde a primeira luta de indígenas reapropriar o repouso da terra com a recuperação do imóvel o Credo, no ano de 1969, onde eles viveram sob o jugo das terrajeria 100 famílias indígenas. Foi também nestes três guardas facilmente onde foram suprimir o terrajeria (CRIC, 1978, p. 15). 
Para aproveitar da melhor maneira possível as terras recuperadas, a nasa ao município de Toribío organizaram-se em comunidade como cooperativas e compras de empresas que produzem e comercializam bens de consumo primário. Também cria a primeira escola bilíngüe em 1979 por iniciativa da abri, para recuperar a fazenda potrerito na calçada que leva o mesmo nome. Além destas iniciativas, começaram a gestar programas e projetos que buscam a promoção integral da comunidade de três guardas.

\subsubsection{Projeto da Nasa}

"O governo sempre é colocado na parte do poderoso defendendo seus interesses, mas os interesses da pobre necessidade de defender a comunidade de organizada".

Sacerdote indígena nasa pai Álvaro Ulcue Chocué

O início da recuperação do território ancestral e fortalecimento organizacional alcançado durante a década dos anos setenta, originou vários projetos comunitários que procuraram reforçar a conselhos, a autonomia e a identidade. Neste contexto de desenvolvimento social o pai Álvaro Úlcue Chocué será integrada em 1975 o primeiro católico padre da nasa, como chefe das freguesias dos territórios indígenas do município de Toribío, que seria uma parte chave na formulação e no desenvolvimento do projeto da Nasa ou plano de comunidade de vida dos guardas da ordem Toribío, San Francisco e Tacueyó. con para contribuir para os esforços que chegou em frente ao configurar e organizar um processo de desenvolvimento social abrangente, pai Ulcue20 junto com as irmãs Laurita 21 e moradores dos três territórios constituída em 1979, a equipe missionária, que propenderia para a evangelização inculturada e liberando da comunidade indígena com base em iniciativas que procuraram reforçar o projeto de vida comunitária que mais tarde se tornaria conhecido como projeto da Nasa. De acordo com sociólogo Naftaly Matogi (2013), a finalidade do fundo da equipe missionária

Foi a criação de uma comunidade dos fundamentos bíblicos da "nova terra" e "novo céu", onde seria estender o "Reino de Cristo ressuscitado" (carta do pai Úlcue diretor de Fastenopfer, 25 de abril de 1983). A missão da equipe era "construir o Reino de Deus. Mas não um teórico Reino de Deus, um reino de Deus muito concreto, visível em uma nova comunidade, um Unido, organizada Comunidade, trabalhador, alegre, honesto, saudável, treinados, tecnologia autônoma, cofre, Católica Cristã. O sonho que moveu 
o coração e os pés do missionário equipe foi identificado com o sonho bíblico do "novo céu" e a nova terra", "homens novos" capaz de ser sinal e 122 instrumento da nova comunidade. Esta nova comunidade foi uma igreja "povo de Deus", com o próprio rosto. Para atingir este objetivo, usamos instrumentos e estratégias diferentes. Em primeiro lugar, o elenco é mão de capacitação de líderes indígenas para performances de comunidade (MATOGI, 2013, p. 48).

Para fazer um diagnóstico panorâmico da realidade dos problemas que atormentam a população, pai Úlcue com a equipe e três guardas missionário e a permissão e apoio dos conselhos realizada em 1979, um censo paroquial, que seria a base para a formulação do projeto de "Deixar Unidos", que é incialmente priorizados três programas: evangelização lojas de comunidade e educação bilíngües e projetos produtivos. Aproveitando-se de treinar os líderes da ação Cultural Popular de Sutatenza em Boyacá, 20 membros da Comunidade formaram da nasa em aspectos políticos, econômicos, sociais, culturais e religiosos para que eles liderar e gerir os diferentes programas do projeto.

Era um programa no Ministério social rural, que contou com o apoio do social pastoral rural, nacional e regional nível de treinamento e com o apoio financeiro da conferência do bispo católico dos Estados Unidos. A parte do programa de um projeto de pastoral social rural do Vicariato do norte da Arquidiocese Católica Romana de Popayán. Nível de escolaridade foi com a ajuda do camponês maior Instituto de Buga (WSBI) e o Instituto Catequético diocesano de Popayán. A ação quaresmal Suíça (Fastenopfer) estava respondendo por problemas financeiros (MATOGI, 2013, p. 24).

Com este projeto era fortalecer a construção da autonomia, a unidade de comunidades e desenvolvimento social abrangente. Então foi obra das marchas equipe projeto juntos para educar e capacitar todas as comunidades para que todos pudessem participar em processos, projetos, decisões e as organizações da Comunidade. Enquanto o pai Úlcue denunciado das fazendas do púlpito, injustiças e ultrajes que pesava sobre os indígenas. Na busca de promover o projeto de deixar Unidos iria ser programado com a colaboração e aconselhamento do centro para a promoção 
de projetos de Desarrollo22. Dois seminários para o conhecimento dos problemas nos três territórios.

O primeiro seminário foi realizado entre 8 e 12 de setembro de 1980, e a segunda, em que estabeleceu metas a alcançar e programas desenvolvidos no financiamento de projetos, realizou-se entre 27 e 29 de abril de 1981. Moradores de três guardas, 144 no primeiro e no segundo 42 participou de dois seminários (MATOGI, 2013, p. 75).

Os participantes do primeiro seminário foram divididos em doze grupos para refletir e identificar problemas ou questões para trabalhar na Comunidade.

Como resultado da coincidência de problemas ou questões identificadas pelos diferentes grupos, foram escolhidos como temas de aprofundamento, a modernização agrícola, a unidade base das cabildos, educação bilíngue, status de indígenas, a recuperação de terra, alfabetização, empresas comunitárias, cooperativas, ação comunitária, mina de mármore, desmilitarização, expulsão do grupo religioso, Ágape e o treinamento de mulheres (Cenprodes seminário de planejamento (, Setembro de 1980, p. 58).

O segundo seminário passou-se um planejamento completo para o desenvolvimento de três guardas, que inclui tópicos tais como: educação bilíngue, evangelização, saúde, modernização agrícola, trabalho comunitário, construção e melhoria home. Definidos como mecanismos de ação, reuniões regulares de artistas indígenas ou delegados da palavra, encontros de professores e reuniões de conselhos, de acordo com o missionário Chanduví et, seminários workshops tinham uma boa organização firme, com preparativa reuniões sobre temas e metodologias. "Doze grupos de trabalho foram constituídos com coordenadores e relatores. Muitos desenhos foram feitos para apresentar diferentes aspectos da vida comunitária e para a adopção das propostas, uma vez que muitos dos presentes não sabia ler ou escrever". (CHANDUVÍ, 2011, P.160). Para os participantes dos seminários que iria originar a Nasa projeto ou plano de vida comunitária, com isto, ele procuraria o próximo objetivo.

Queremos nossa comunidade para ser: Unidos por meio de conselhos, através de orientações, reuniões, colaboração, inspeção e sanções; 
trabalhador em toda a Comunidade, por meio de mingas, mudar na mão, comunidade empresas e lojas da Comunidade; Alegre, através de instalações de lazer; uma honra através do trabalho e a formação da casa; treinado por meio de escolas, oficinas e cursos; Tecnologia através de institutos; saudável através de uma boa alimentação e centros de saúde; Sem politicagem e festas; segurança através da guarda cívica, cristãos católicos, através do evangelismo e desmilitarização (Acta de seminário Cenprodes-Paez comunidade indígena, 1981).

Censo paroquial e as conclusões do hands-on do planejamento permitiram comuneros nasa tem um diagnóstico da situação política, económica, social, educacional, cultural e religiosa dos três guardas. Que brindo124las as diretrizes para a elaboração do plano de trabalho dos programas, com metas específicas que permitam o desenvolvimento integral e social da Comunidade. Logo após o segundo workshop, foi o primeiro projeto de financiamento cujo objetivo era alcançar o fortalecimento organizacional dos conselhos dos três guardas para uma promoção abrangente da nasa indígenas de Toribio, Tacueyo e San Francisco, através da realização dos programas de evangelização, educação bilíngue, saúde, habitação e agricultura modernização.

O conjunto de programas selecionados pelos participantes dos dois seminário de planejamento foi chamado de "Projeto da Nasa," os três guardas, conhecidos como "Plano de vida comunitária". Foi um projeto que ultrapassou até mesmo as comunidades, o que era apropriado, traduzido e resinificado comunidades de acordo com suas expectativas, interesses e lutas locais. Uma vez que não tinha recursos para a execução dos programas, sentiu a necessidade de apelar para entidades estrangeiras. Para isso a freguesia de Toribío assumida o papel da personalidade jurídica do projeto da Nasa e da equipe missionária juntamente com as comissões de cada programa, assumiu o papel de executor, como conselhos responderam pelo controle. (MATOGI, 2013, P.77).

Cinco programas foram selecionados para lançar o projeto da Nasa, coerente com as prioridades identificadas pelas comunidades. Com a criação da Nasa projeto, no final de 1980, terminou o projeto "Deixar Unidos", e animadores de comunidades passaram a fazer parte do 
projeto da Nasa. De Matogi (2013), por 30 anos de implementação deste processo de desenvolvimento social abrangente acordo foram implementadas mais de 143 projeto nos diferentes programas. O gráfico ilustra o número de projetos financiados no âmbito do programa do projeto da Nasa durante 30 anos 1980-2010.

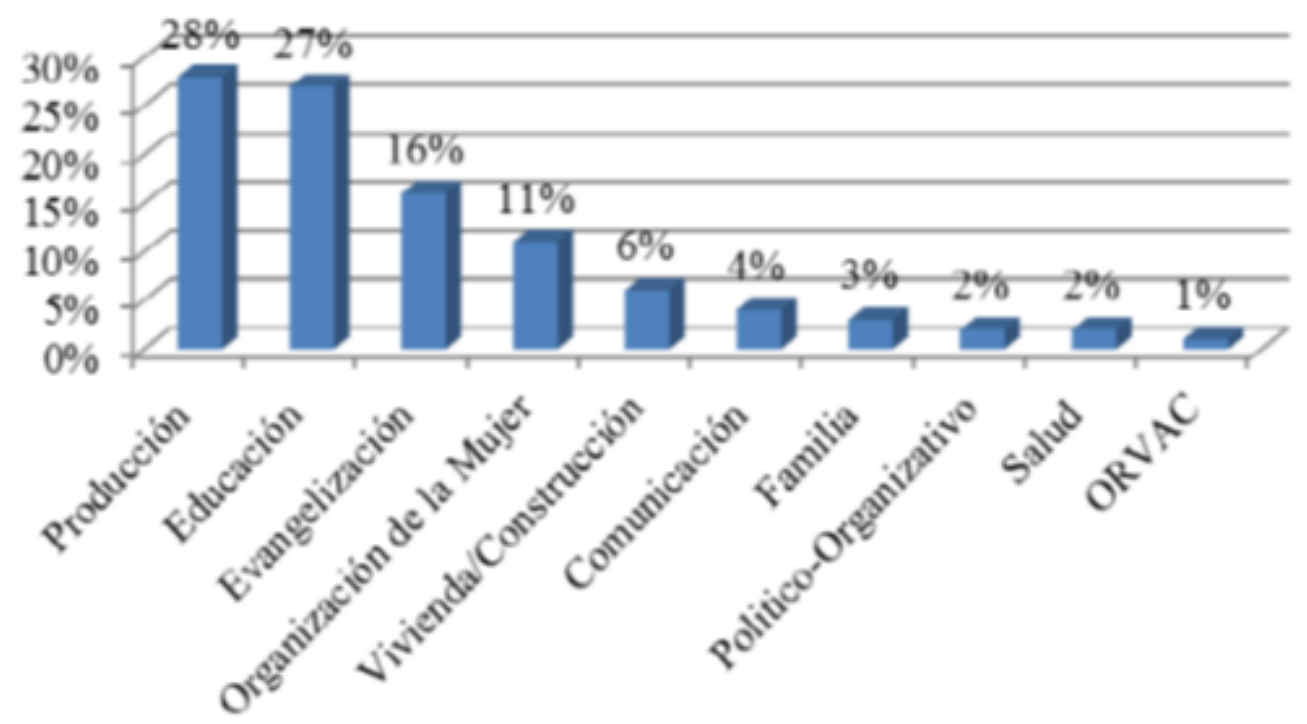

Figura 20 Proyectos financiados segun los programas del proyecto Nasa MATOGI (2013, P.78).

Alguns dos projectos financiados envolveram a construção de infra-estrutura física nos três territórios. De acordo com MATOGI (2013, p. 62) distribuição dependia, entre outros, o número da população da recepção e a disponibilidade de terras alocadas os cabildos. 19\% desta infraestrutura está localizado em San Francisco, em Toribio, 7\% e 5\% em Tacueyo. 69\% dos projectos revistos não envolveu a construção de infra-estruturas físicas, como você pode ver nas infraestruturas do gráfico. 


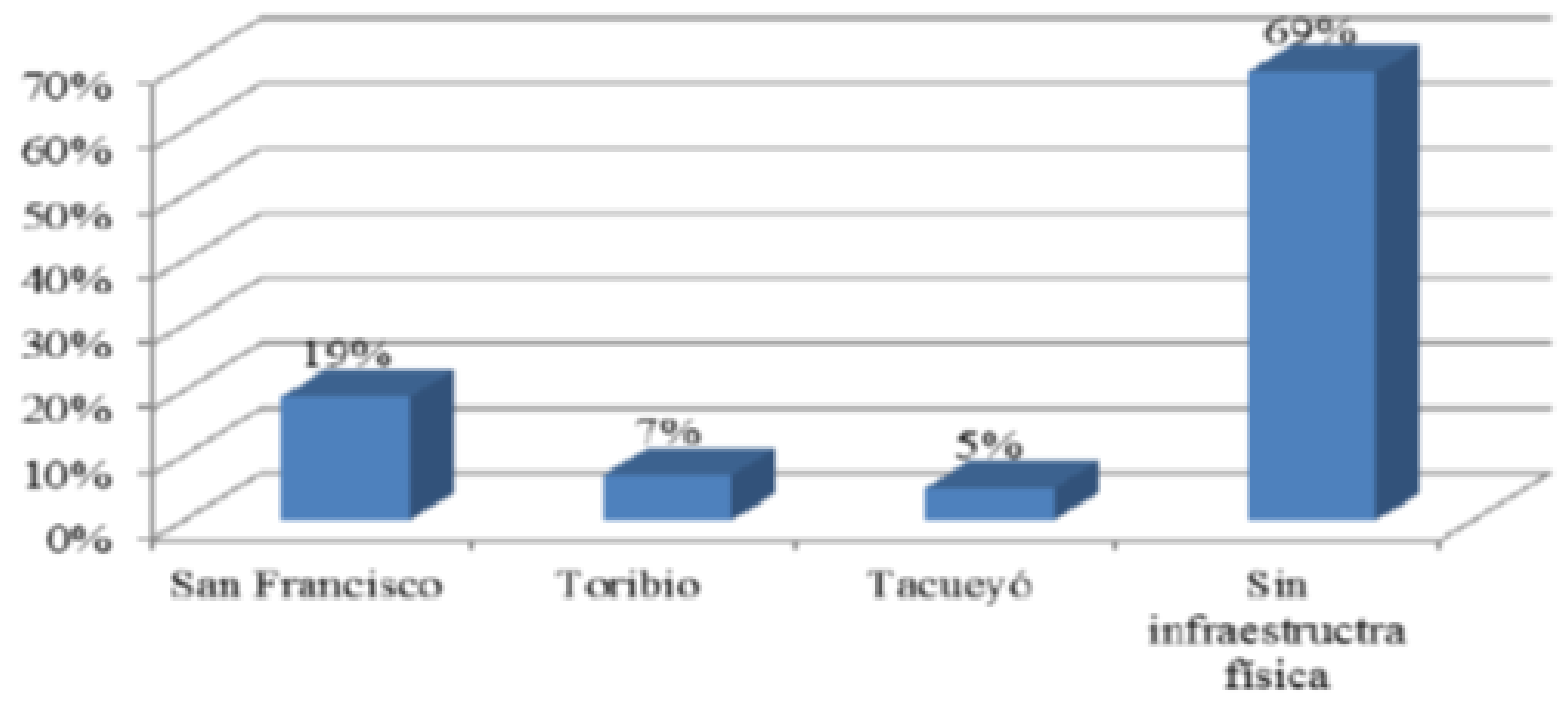

Figura 21 Resguardos beneficiarios de las infraestructuras del Proyecto Nasa: 1980-2010 (MATOGI, 2013, p. 62).

Projeto Nasa programas foram financiados em grande parte pelo tribunal eclesiástico, organizações ligadas à Igreja Católica ou o inspirou com 79\%, 6\% do tribunal civil e os restantes $15 \%$, com a concordância dos dois tipos de entidades.

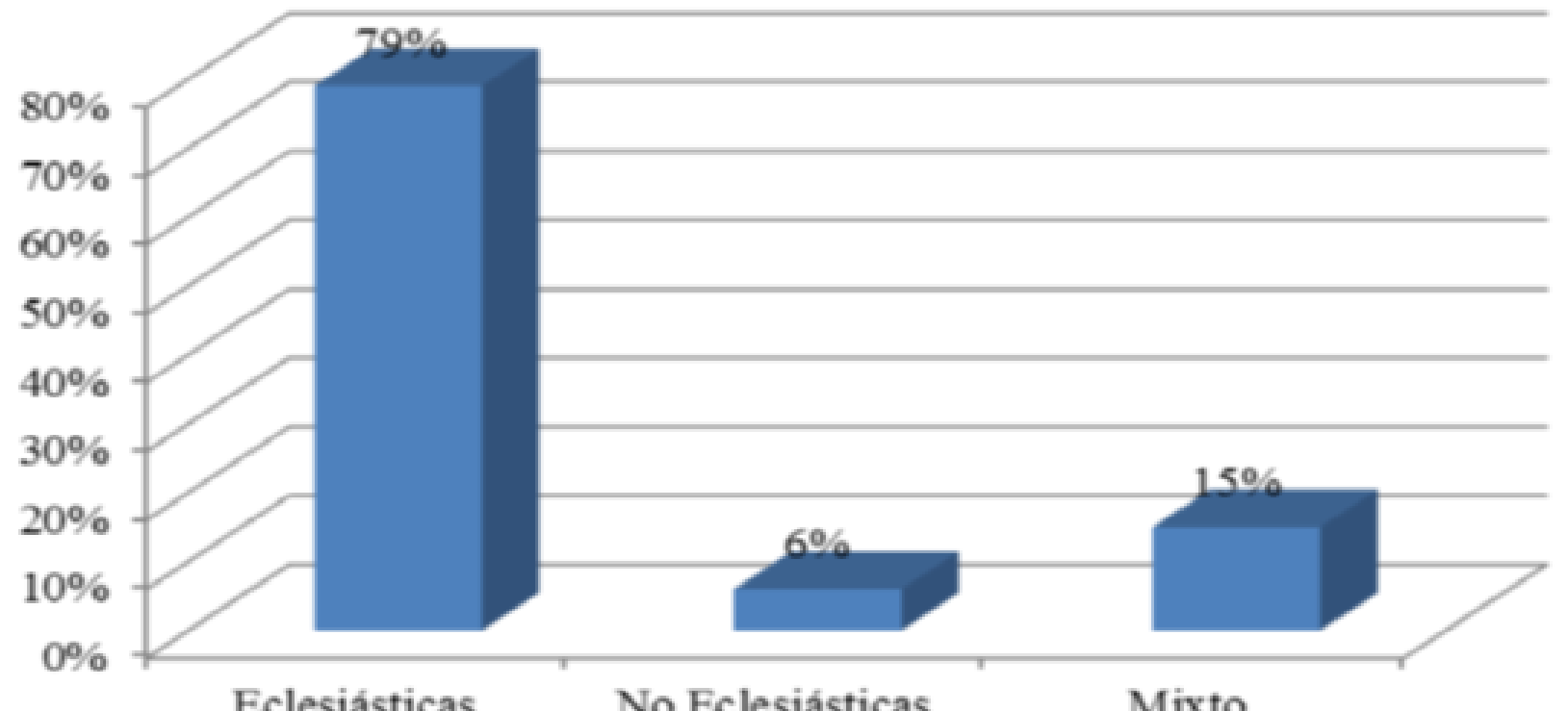

Figura 22 Outros organismos de financiamento dos programas de projeto da Nasa. MATOGI (2013, p. 90).

O $86 \%$ dos projetos foi financiado por entidades estrangeiras, enquanto $14 \%$ assistiram a contribuição nacional. É pertinente mencionar que, a partir de 1991, alguns projetos receberam recurso do SPG através o esquema descrito no segundo capítulo. Recursos próprios como produto de produtivos de empresas ou projetos a Comunidade. 


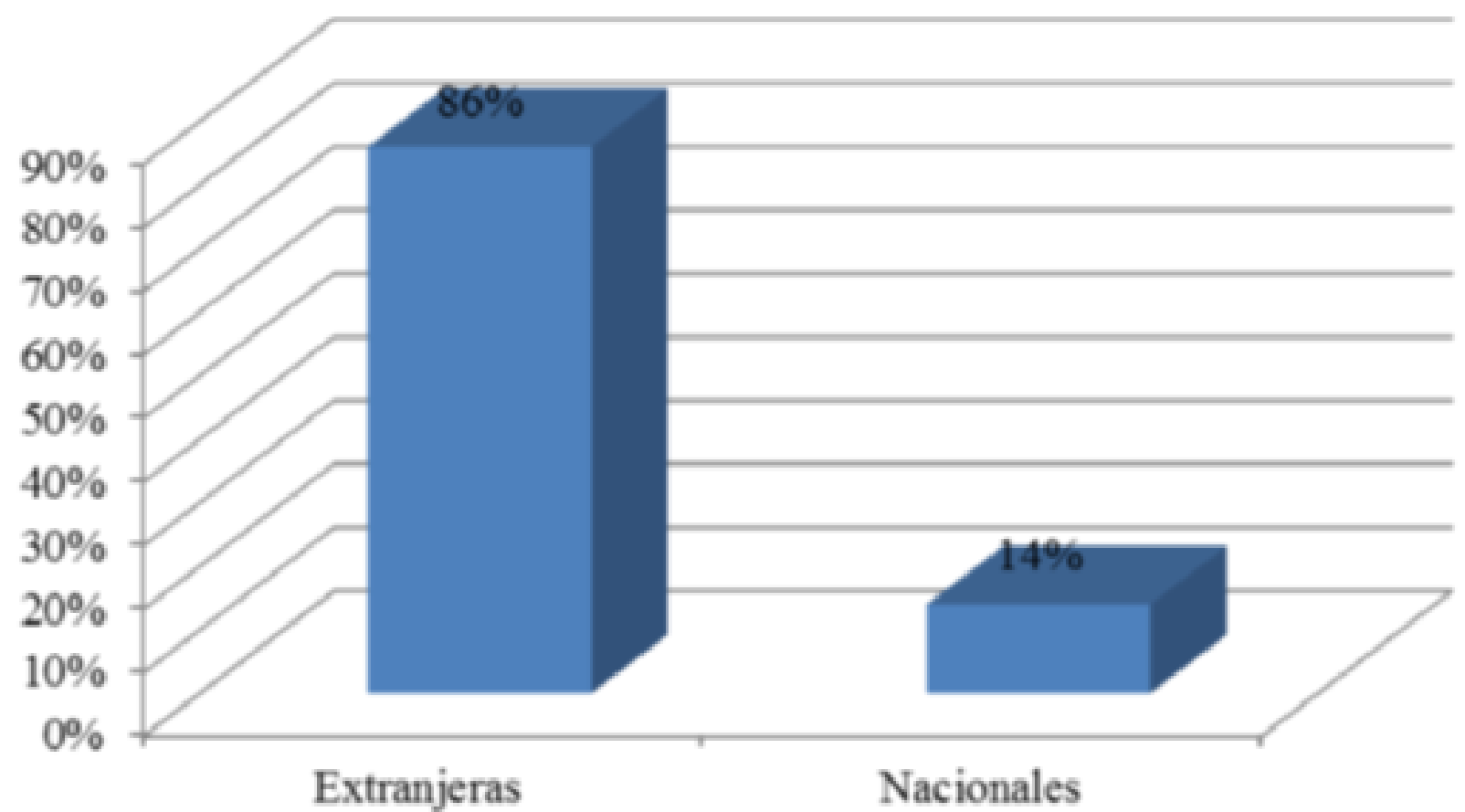

Figura 23 Perfil de projetos de financiamento a entidades: 1980-2010 MATOGI (2013, p. 91).

Um dos principais programas do projeto da Nasa é a produção, que inclui iniciativas como empresas, lojas e hortas comunitárias. Como fundo de maneio-fritas, veículos e micro-empresas. Lojas comunidade surgiram nos territórios indígenas de Cauca, a recuperação de terras e o estabelecimento da abri em 1971. "Fim de Pesquisar o progresso da Comunidade, evitar a exploração dos intermediários e facilitar a distribuição de bens básicos na Comunidade no âmbito do apoio e solidariedade com o Cabildo e a Comunidade" (estradas ACIN e Fundação da identidade 1997; 39)

As lojas de comunidade primeiras apareceram em Toribío, Tacueyó e San Francisco, em 1978, da recuperação de terras, especialmente como um auxílio para povos indígenas empenhados na luta. As duas primeiras lojas nasceu em San Francisco e Potrerito (hélio), com a intenção de promover a unidade, a autonomia e a solidariedade das comunidades em momentos de dificuldade. Desde 1979, com o projeto "Deixar unida", a equipe missionária tomou lojas da Comunidade como parte de sua ação pastoral. Quando nasceu o projeto da Nasa como um conjunto de vários programas, o programa de lojas da Comunidade aderiram ao projeto como um componente do setor de produção entre 1980 e 1981 (minutos da 
Assembléia da programação projeto da Nasa, 2-3) Citado por MATOGI, 2013, tecnologia).

A criação de lojas da Comunidade foi um acontecimento significativo, desde com eles conseguiram regular os preços dos produtos, treinar muitas pessoas e presente crédito de serviço ou fundos de solidariedade para os comuneros. Para tirar proveito de uma recuperação global da terra, os conselhos dos três guardas decidem a criação de empresas comunitárias para a produção e comercialização de bens de consumo. No âmbito da Nasa projeto, em 1981 nasceu a produção com o programa de 4 empresas e o número foi crescendo rapidamente. Desde a sua criação, a dinâmica do projeto da Nasa o sétimo ponto da plataforma de luta do abri chama para formação de professores que ensinam de acordo com a situação dos povos indígenas e na sua respectiva língua.

Em 1979, a licença do projeto Unidos tinha assumido o bilíngüe como um dos eixos de suas ações. Um ano depois, no nascimento o projeto da Nasa, programa de educação bilíngüe é integrado ao programa de educação para o novo projeto, e partir do final deste ano, as comunidades começaram a selecionar candidatos para professores bilíngues e começaram um treinamento. Conselhos e comunidades, juntamente com o padre Álvaro Ulcué e o abri, eram responsáveis para a formação, o acompanhamento e a avaliação de professores, ensinando os aspectos no conteúdo e na metodologia de educação bilíngüe, tendo em conta a cultura, história e língua (relatório da quarta Assembléia Geral do projeto da Nasa. Citado por MATOGI, 2013, p. 82).

No âmbito deste programa, desde 1992 iniciou a construção do centro de educação, formação e investigação para o Desenvolvimento Integral da Comunidade - CECIDIC, que tem formal e informal, com graus de primário, secundário e superios desde 1996 estabelecido uma filial do Instituto missionário de antropologia-IMA em Toribio, membro da Universidade Pontifícia Bolivariana, sob a responsabilidade da missão da equipe. Lá também opera escolas de artes e ofício, corte e costura, carpintaria e escola de agro-ecologia.

É um centro que, desde a sua criação, tornou-se modelo de educação indígena no norte de Cauca. A nível linguístico, programa de educação tem-se empenhado no resgate e revitalizar a Nasa Yuwe criado para o seu aprendizado e difución material através da comunidade de ensino de 
projeto de etnoeducativo. $\mathrm{O}$ que começou como um programa de educação bilíngüe como gradualmente tornou-se uma formação abrangente e programas de educação, em que centenas de indígenas da nasa ter sido formado em vários aspectos, desde o social até o religioso, o político, o econômico e o cultural. A contribuição do projeto da Nasa em conjunto com o esforço de outros setores nos três guardas, levados a uma mudança qualitativa e quantitativa no campo educacional, como um antigo presidente da Câmara Municipal e ex-coordenador do plano de vida da Comunidade:

O plano de vida tem sido complementado por programas que foi criado a partir do projeto da Nasa. Se por exemplo aqui há vinte anos não saiu mais de 300 alunos, há não mais de 300 alunos no município são agora mais de sete mil, 20 anos, se alguma coisa saiu 3 bachilleres indígenas agora anualmente estão saindo mais de 400 graduados, ou seja, praticamente já se houver uma mudança. Se antes os indígenas não em direção a escola já é fazer a Universidade, então isso é muito, muito foi prioritariamente a educação para um plano. (Entrevista com um ex-prefeito do município e líder indígena, de março de 2011. Citado por MATOGI, 2013, P.95)

Como parte das propostas constituintes da Nasa projeto é o programa de evangelização, do que da sua "casa procurou contribuir para a formação de novas comunidades através de um processo de evangelização inculturada, libertadora e integral" (projeto: formação e integral promoção da Comunidade Paranhos, 2006-2007) Citado por MATOGI, 2013, p. 82).

Programa de evangelização do centro de espiritualidade, teologia e Pastoral da Nasa-CETEPAN, como um instrumento para a formação dos delegadosanomadores e espaço para o aprofundamento e reforço das 'raízes' do processo nasceu comunitário (Proyecto: Formación y promoção integral da comunidade Páez, 2003-2004.) Citado por MATOGI, 2013, p. 82).

Processos organizacionais promovido ou habilitadas pelo projeto da Nasa é o grupo das mulheres que eu foi criado em 1983, a fim de coordenar a organização e capacitação de mulheres, "bem, estudando o programa em conjunto com as mesmas mulheres e promovendo (movimento das mulheres indígenas) organizaram grupos de mulheres em todas as comunidades e oferecendo 
serviços de educação e formação" (relatório paroquial, 2002-APSJB. Citado por MATOGI, 2013, p. 82).

Em 1991 o programa tornou-se movimento quando ela se expandiu para guardas do norte do Cauca. Através de oficinas e cursos, está procurando mulheres aprender uma profissão para gerar recursos para se mesmo, para suas famílias e comunidades, evitando a migração. Foi, além disso, a necessidade de treiná-los para compreender a sua realidade e, portanto, conquistar a autonomia, a decisão e o controle de processo (MATOGI, 2013, p. 84).

Outro plano de vida abrangente da comunidade conhecido como programas de projeto da Nasa, é a de comunicação.

Esta casa na década de 1980, com quem foi responsável por folhetos, vídeos e gravações de convidar a Comunidade a participar nas reuniões. Essas pessoas também eram responsáveis por recolher as memórias dos mais importantes eventos de guardas e a sensibilização da Comunidade. Desde 1995 estes temas começaram a capacitar-se na gestão de programas de rádio. E quarta Assembleia Geral do projeto da Nasa em abril de 1991, na aldeia de Berlim, protegido de San Francisco, nasceu a proposta de uma estação própria, a fim de promover e divulgar o projeto da Nasa (minutos do projeto quarto Assembleia Geral da Nasa; Projeto de rádio da Nasa, 1997. Citado por MATOGI, 2013, P.85).

Realizada a Assembleia dos conselhos de Toribío, estação de San Francisco e Tacueyó, entrada no ar com o nome de stereo da Nasa seria substituída um ano mais tarde pela Nasa de rádio. "Então a estação contase contase com certa estabilidade econômica, foi concebido e apresentado um projecto para a Suíça ação quaresmal (Fastenoper) onde é dinanciacion pedia por dois anos, das oficinas de treinamento e folha de pagamento da base de grupo" (Projeto rádio Nasa, el de pará Informe Projeto Nasa, Toribío, 6 de febrero de 1998).

Para pesar que, na década de 1980, a equipe missionária promoveu o movimento familiar cristão, foi em 1999 com a convergência das diversas iniciativas é o Conselho da família no projeto da Nasa. E em 2000 foi realizada a primeira reunião de família (ver Associação projeto da Nasa e 
Pontificia Universidad Javeriana, 2007, p) cuidados de saúde é um dos aspectos abordados do projeto "Deixar Unidos", até que se tornou um dos cinco primeiros programas do projeto da Nasa.

Em seguida, saúde foi um dos principais problemas dos três guardas, há anos uma negligência crônica e profunda. Serviços médicos foram fornecidos pelas irmãs lauritas através de uma comunidade Kit e um grupo de mulheres conhecidas como "Amigos da saúde". O desenvolvimento do projeto Nasa treinamento em primeiros socorros e de aquisição de kits de valores, esses promotores de saúde funcionaram como catalisadores dos processos.

De acordo com o que consta da acta da quarta Assembleia Geral do projeto da nasa Los Jesuitos colaborou com medicinas para a dispensário-farmácia em Toribío, atravessa o camponês maior Instituto de Buga, enquanto a Arquidiocese deu remédio para postos de saúde. Ao mesmo tempo a equipe missionária abriu uma farmácia em Toribío, encarregado das irmãs Lauritas, mas anos mais tarde foi confiada à comunidade de cuidados "(Acta de la quarta asamblea general, Berlim, 22-24 de abril deel, 1991)."

Graças a gestão dos conselhos, o projeto da Nasa e da Comunidade em geral, foi alcançado entre 1985 e 1987 a construção do Hospital "Alvaro Úlcue" de Toribio, nome dado em homenagem ao gerente, mentor e caminho do projeto da Nasa que iria ser assassinado em 10 de novembro de 1984, no município de Santander de Quilichao macraba da Aliança de proprietários políticos e traficantes que viram seus interesses ameaçaram pelo trabalho emancipatório de pai Alvaro Úlcue.

Em 1987, com a avaliação global dos seminários projeto da Nasa, coordenadores foram escolhidos para comissões de forma de saúde em começaram a busca por funcionários dos guardas em Tacueyó, Toribio, San Francisco para treinamento como promotores de saúde. 1988 foi um ano de aprofundamento da formação sob a orientação do Lauristas irmãs e leigos. Aqui foi determinar o papel assumido pela entidade estrangeira, "Pão para o mundo" e o programa de saúde da abri (acta da assembleia geral quarta, Berlim, San Francisco, 22-24 de abril de 1991; Acta da reunião do Conselho de saúde de Toribío, 27 de setembro de 2001. Citado por MATOGI, 2013, p. 89). 
Com a saúde programa também está buscando recuperar, promover e fortalecer a medicina tradicional. Conjugando-se ocidental e a medicina tradicional para o bem-estar da Comunidade. Entre 1980 e 2010, 2\% dos projetos do plano de vida da Comunidade foi destinado para a saúde.

Outros programas do projeto da Nasa foi o resgate dos valores indígenas e organização Cultural. Começando em 1981 com a organização de reuniões de música indígena e a exposição de artesanato, pela equipe do missionário, juntamente com os mestres oficiais do município. Promoveu a recuperação e a recriação do nativos mitos e lendas passadas redução após geração através da tradição oral. Da mesma forma é impulsionar a recuperação e o uso de yuwe a nasa como sua própria língua. Também recuperado e concedeu o praticas dos rituais relacionados à sua visão de mundo e calendário, entre outras atividades.

Promovidas campanhas de leitura em Páez, baseando-se na Kuesh Iuwe (nossa língua ou nosso idioma), publicado por Álvaro Ulcué Primer (projeto: pastoral profética, em 16 de julho de 1984). 'Alvaro Úlcue pai iniciou o desenvolvimento de oficinas sobre a cultura de Paranhos com professores oficiais na escola de Toribío (1980), de que é o projeto alfabetização cartilha Cuesh Iuwe (ASSOCIAÇÃO PROJETO DA NASA E PONTIFICIA UNIVERSIDAD JAVERIANA, 2007, p. 27).

A nasa sobre o fortalecimento dos processos organizacionais e as próprias autoridades, sucede a três comunidades que interessam no passado estrangeiros tinham dividido ideologicamente, aglutinaram em torno de um plano de vida comunitária, e principalmente oferecer suporte a um único movimento político nascido do mesmo processo, ganhando o controle da administração municipal para ser eleitos representantes do processo comunitário em cargos de eleição popular, desde 1994.

Também foi constituídas a associação de cabildos e autoridades indígenas tradicionais do município de Toribío projeto da Nasa de acordo com o decreto 1088 de 1993. Sendo uma instituição comunitária, reconhecida como uma entidade pública de caráter especial para a gestão e a gestão local dos territórios indígenas. Atualmente, a Associação dos cabildos e autoridades indígenas tradicionais do município de Toribío, conhecido como projeto da Nasa desenvolve iniciativas, atividades e projeto de seus diferentes programas, leitura e feedback a nível local e zonal indígena projeto político do abri em sua plataforma industrial. 
O projeto da Nasa tem contribuído para a geração de mudanças significativas na dinâmica da interação social dentro das comunidades e destes com a sociedade de vinculação, originando uma nova geografia sócio-política na região. Ganhando um importante reconhecimento e admiração de diversos setores sociais e instituições como a UNESCO, que definiu os povos indígenas do território do município de Toribío como laboratórios sócio-cultural, e como resultado, estabelecido uma cadeira UNESCO de Nasa nos processos da Comunidade.

\subsubsection{Plano de vida da comunidade nasa}

"Plano de vida não é um documento, é o sonho do povo a Nasa e a maneira de torná-lo realidade." Ao vivo que o plano de vida é dar a palavra aos desafios de mudanças de cada era da história e a realidade de todos os dias ${ }^{11}$."

A Constituição de 1991reconhecendo o caráter pluriétnico e multicultural sociedade colombiana é dada para os povos indígenas direitos culturais diferenciados relacionados administração ou governo dos territórios coletivos de planejamento de acordo com suas formas de uso e costumes. Para o qual prevê o estabelecimento da entidades territoriais indígenas-ETIS no processo de descentralização política administrativa do estado. Para fortalecer o local administração no âmbito da descentralização administrativa surgem os planos de desenvolvimento como instrumentos gerais que guia a ação pública em entidades territoriais municipais e departamentais. Para os territórios indígenas da ETIS tem a protesta e a obrigação de criar mecanismos semelhantes a estes planos de desenvolvimento ou programas de desenvolvimento econômico e social no seu território, em harmonia com o plano nacional de desenvolvimento "(article 330), procurando são bem manter a reprodução física e social dos povos indígenas, seus modos de vida e permitindo a prática de suas tradições e costumes nos territórios indígenas.

Os mecanismos de planejamento elaborado pelo indígenas andinos departamento de Cauca e aceites pelas instituiçõos estado incluem planos de vida, que estabelecem os elementos necessários para a sobrevivência cultural dos povos indígenas e suas relações com o estado e a sociedade nacional no contexto da inclusão etno-culturais. A direcção-geral para assuntos indígenas - DGSI - do Ministério do Interior da Colômbia, em elementos de documento para a

\footnotetext{
${ }^{11}$ ACIN, presentación institucional, 2005.
} 
elaboração de uma cartilha de treinamento para apoiar a elaboração de planos de vida dos povos indígenas, que gera os "planos de Vida".

[...] Eles pretendem coletar a cosmovisão dos povos indígenas, sua visão de futuro e a condições de garantia de sobrevivência no momento, esta declaração do próprio pensamento. [...] Planos de vida devem dizer quais são as regras existentes para melhorar o jogo da comunicação em igualdade de condições e respeito entre a cultura indígena e a cultura ocidental; entre as autoridades indígenas tradicionais e prefeitos, governadores e presidente da República. [...] Planos de vida devem ser expressos para o resto da sociedade, a maneira de interpretar a vida, de pensar e agir e estabelece os termos que você deve definir as relações com as comunidades indígenas. Para fazê-lo é estabelecido os princípios fundamentais para a sobrevivência destes povos como grupos étnicos com uma visão de mundo e costumes diferentes da sociedade dominante. [...] O plano de vida também deve ser elaborado a partir da participação da Comunidade, que envolve todos os membros: homens, mulheres, crianças, idosos e major, líderes e autoridades locais (Citado por Rojas, 2002:341-344).

Esta figura dos planos da vida tem foi apropriada para cada um dos povos ou comunidades de forma diferente, sob a forma de sua elaboração, conteúdo e uso como uma ferramenta política. De organizações indígenas nacionais como ONIC (Organização Nacional Indígena da Colômbia), tem promovido o conceito de planos de vida e regional (Regional indígena Conselho de Cauca) abri, salientando a necessidade de construir uma visão de desenvolvimento que permite a realização dos objetivos definidos pelas comunidades "desde o início de suas lutas para alcançar o seu reconhecimento e inclusão equitativa da nação colombiana" (Vieco (, 2010:136). Contra a posição de "planos de desenvolvimento são vistos como um pouco mais prático imposto de fora ou seja, principalmente, as necessidades de curto prazo padrão categoria guardas" (GOW, 2005, 341).

O X Congresso do abri desenvolveu esta distinção e propôs que os guardas se centrará em direção a planos de vida, "é recomendado para falar sobre planos de vida e não tem planos de desenvolvimento para que possamos construir nosso destino de nossa própria lógica" (abri, 1997, p. 51). 
Estes arranjos vivos são realizados com recursos do sistema de participação geral, recursos próprios das comunidades e agências de recursos cooperacion133internacional. Para a implementação e desenvolvimento de metodologias e assessoria na implementação dos planos de vida são contados com a colaboração de agentes externos como o município de Toribío, descrito na seção anterior.

Existem planos de vida, da mesma forma que o link dos povos indígenas com a Administração Municipal e departamental para a formulação e implementação de políticas públicas da abordagem diferencial nos programas de saúde, educação, projetos produtivos, entre outros setores. Alguns pesquisadores como Gow, (1998), e Rojas, motivação (2002) que os povos indígenas tiveram que formular seus planos de vida, se relaciona com a exigibilidade dos direitos culturais diferenciados concedidos pela constituição do multicultural.

No entanto, Rojas (2002), também torna claro que "os povos indígenas tiveram seu projeto de vida e estratégias se relacionam com a sociedade de maioria. Prova concreta disso é sua própria existência e permanente interpelação que faz de nós para que nós fazemos não entorpeçamos seu desenvolvimento." A este respeito podemos citar anciãos dos povos indígenas da Amazônia Uitoto, Tikuna, Bora e Cocama da Amazônia:

A vida indígena plano havia trabalhado desde o início do mundo, já foi definido porque nossos avós tinham a gestão ao redor do mundo. Povos indígenas sempre tinham vida plano porque éramos parentes melhor e em harmonia com a mãe natureza e Deus, que nos deixou tudo organizado e ordenado de todos os seres (ASOAINTAM, 2007).

O plano de vida como um processo social, nas palavras do líder Valencia Feliciano:

[...] não é um documento, mais que isso é a memória dos povos [...] deve ter cuidado porque existem planos de vida que pensam mais em aspectos técnicos e economicamente, e isto é delicado, porque ele pode induzir em erro os princípios [...] se as perguntas fundamentais são claras, você pode enfrentar qualquer coisa, porque identidade é refletida na memória, que é o que permite que para não nos enganar sobre os princípios do plano. (Citado por OVIEDO, 2014).

No caso dos três guardas do município de Toribío, plano de Nasa de comunidade-projeto de vida, vem do reconhecimento constitucional década anteriro e responde à Comunidade e 
dinâmica organizacional que procuraram por um planejamento local de alternativas para os problemas da população indígena. O projeto da Nasa concebeu o plano de vida como uma estratégia abrangente para a recuperação e a sobrevivência dos povos indígenas da Nasa e da cultura, então, portanto, abrange vários aspectos tais como a recuperação da terra ancestral, sua dotação ou "Harmonização" desde a cosmovisão da Nasa e sua matéria de controle e espiritual do exercício da sua competência especial indígena.

Com grande esforço, os três guardas nasa pessoas conseguiram superar as vicissitudes e contradições apresentadas mais de 30 anos da configuração do plano de vida comunitária. Gestando-se entre a Comunidade e as autoridades tradicionais, a concepção de que a vida os planos não são limitados para ser uma lista de projetos, uma lista de necessidades financeiras e as despesas. Pelo contrário, para a nasa, o município de Toribío tem sido a iniciativa que lhes permitiu a desconstruir o território ancestral e organizar um processo de desenvolvimento integral dos seus habitantes.

A finalidade do projeto da Nasa não é apenas aliviar as necessidades sociais do momento, mas também a transformação da sociedade estabelecida. Esta iniciativa pretende contribuir para a superação da exploração, económica e política dos três guardas, causada pelo gamonales, latifundiários, políticos e comerciais intermediários. De acordo com o antropólogo David Gow, nasa oscilam entre tradicionalistas e propostas modernizadoras mais planos de vida.

Nele, o motor discursivo do processo organizacional ainda é tradição. Mas é uma tradição que reconhece a dinâmica atual, as transformações que enfrentam as comunidades, que não estão limitadas a uma representação essencialista, na qual a nasa são representadas como congelados no passado. Por outro lado, é usar a tradição para propor alterações para a situação atual dos povos indígenas, incluindo os problemas económicos e perda de estágios culturais, bem como outros problemas (GOW, 1998, p. 150).

Os planos de vida de comunidade é baseado sobre os preceitos culturais, da qual a nasa afirmar-se como povos e autónoma. Neste sentido é uma estratégia de longo prazo para o desenvolvimento integral da Comunidade dos guardas, tendo em conta todos os aspectos da sociedade e da cultura indígena, incluindo seu caminho de progresso e a maneira de viver e 
organizar. O plano de vida de comunidade do município de Toribío, conhecido como projeto da Nasa uma meta-narrativa do índio planejamento pode ser considerado.

Foi um dos primeiros deste tipo em Cauca e serviu como modelo para outras comunidades. Planos de vida são elaboram em cada um dos guardas e locais ou municipais, regionais, departamentais e nacional; Desta forma, as muralhas de San Francisco, Toribío e Tacueyó tem um plano de vida que integra a vida de comunidade três resguardos municipal que é o plano de projeto da Nasa. Isto por sua vez flui no plano da vida zonal de associação de Cabildos indígenas do norte do Cauca-ACÍN, que faz parte do plano da vida regional, que a regional Conselho Cauca-abri indígena, finalmente, que constituem o plano da vida nacional dos povos indígenas da Colômbia participou da organização nacional dos povos indígenas ONIC.

Tendo em mente que as pessoas nasa em geral e os três reguardos de Toribío em particular, tiveram um projeto de vida ancestral que eles tem permitido relacionarem com sociedade de maioria, mantendo a posse da propriedade de seu território original, sua identidade cultural e cosmovicion, como evidenciado por sua historicidade.

O plano de vida comunitária das últimas décadas tem sido a Comunidade periodizada em vários exercícios de sistematização da experiência de acontecimentos internos e externos que permitem estabelecer as características de cada um dos momentos em que ele era. A primeira fase situa-se nas décadas de 60-70 até 1987, referido como "a fase de inicialização", compreende o segundo período de 1988 a 1993 é catalogado como fase de consolidação, uma terceira fase vai de 1994 a 2004 é designado a abertura e a quarta e última fase de 2005 até agora é conhecido como o estágio de autonomia.

As primeiras pessoas do palco começaram com os primeiros processos de recuperação de terras em Cauca por organização camponesa que pertencem a nasa. Continuando com o estabelecimento de um indígena com reivincaciones étnico de própria organização como o Conselho Regional de Cauca abri indígenas.

O que fez o surgimento de uma série de programas, iniciativas e projectos que estão a tentar perceber a plataforma política do abri. Este período é conseguido recuperar, reforçar e consolidar o recibo e o cabildo como instituições comunais de auto-governo, recuperar antigos territórios usurpados por proprietário de terras e é a agência de um processo de recuperação e reivencion cultural, permitindo-lhes reforçar a sua identidade como povos nativos. 
A iniciativa mais importante durante este período seria o projeto da Nasa, que articula os diferentes projetos e programas de desenvolvimento social comunitário. Para o financiamento de programas é recurrio às instituições nacionais e internacionais, especialmente para as agências de cooperação internacional do tribunal eclesiástico. A figura do pai Ulcué e sua proposta evangelizadora, sendo decisivo. "Durante toda esta fase foram fortes tensões entre índios e colonos, fazendeiros, chefes, forças militares estado (polícia e exército) e grupos insurgentes". Devido à ameaça da organização das comunidades, a recuperação da terra e sua utilização através de empresas comunitárias para o estado e os detentores do poder."

No meio disto conforntaciones mortos caiu muitos comuneros nasa, incluindo o promotor do projeto, o pai de Álvaro Ulcué Chocue. Em um contexto onde ele recrudescia o conflito político armado e tráfico para uso dos territórios do norte do Cauca crescem coca para fazer cocaína, incrementadose violência e conflitos sociais. A segunda fase ou período localizado no ano de 1988, no final da primeira avaliação comunidade de estilo de vida geral do plano. Dessa avaliação, foi criado o Comitê Central do projeto da Nasa, que responsabilizaria dos projetos sócio-econômica.

A fim de capacitar os espaços de participação cidadã fornecidos pelo processo de descentralização da administração do público, o "movimento cívico de Alvaro Úlcue" foi criado em 1989 para a disputa para prefeito municipal de eleições de partidos tradicionais, o Conselho e o asamablea departamental.

Partir do modelo do projeto da Nasa é impulsaria criar outros projetos ou planos de vida comunitária, como o projeto Global de jambar, a unidade de Paranhos ao município de Miranda, projeto Chacha Wala de Corinto, projeto abrangente de Caloto, projeto $\mathrm{Yu}$ 'luch de tigres Munchique, canoas e Conselho urbano do Santander de Quilichao e projeto Sat' Finxi Kiue de Concepción Delícias e Guadualitos.

Para unir esforços e incentivar a todos esses projetos comunitários em uma abordagem zonal é gestado os Associação de Cabildos indígenas do norte do Cauca, sendo uma entidade de administração e gestão pública povos indígenas territórios locais desta área do departamento. Exemplo dos programas, atividades e projetos de recursos dos associados conselhos e organizações nacionais e internacionais.

A terceira fase começa com a formalização da ACIN e ligação do projeto da Nasa para Administração Municipal local a eleição popular do Presidente da primeira câmara do movimento 
cívico, Alvaro Úlcue. Elaborando-se plano de desenvolvimento municipal de programas e práticas de planejamento e avaliação da comunidade de que são exemplo veio do projeto da Nasa. Então 4 anos depois, em 1998, ganhou o prêmio nacional como melhor plano de desenvolvimento Municipal dos municípios do país com menos de 100.000 habitantes.

Desde a sua criação, o plano de vida comunitária apareceu como um híbrido de realidade, porque neste convergido vários interesses, orientações e protagonistas. No plano da vida coabitam espiritualizes, materiais e interesses políticos e econômicos, sociais e culturais. Neste forças privadas e estatais, Igreja e secular, temporário e intemporal são latinos. Portanto, ao invés de um projeto homogêneo, o plano de vida comunitária sempre era uma realidade múltipla porque muitos eram facetas. E seu grande mérito consistia em ter conseguido transformar este aparente amálgama de elementos em uma entidade com humor e lutas comuns (MATOGI, 2013, p. 112).

A quarta e última fase que compreende desde 2005 até os dias atuais e é conhecida como o estágio de autonomia e tem sido caraterizada pelo fortalecimento do controle territorial, a administração da justiça, sob a sua jurisdição indígena especial, o fortalecimento dos processos organizacionais de comunidade e configuração de novas demandas relacionadas com a constituição das entidades territoriais indígenas autônomas e a oposição dos povos indígenas para a política de conflito armado e o modelo de desenvolvimento extrativistas participaram pelo governo nacional através de suas políticas públicas.

\subsection{Tulpas ou preceitos constitutivos da administração e gestão pública de M. de} Toribío

A administração e governança dos grupos indígenas territórios ao município de Toribío do povo que NASA é baseado em uma série de preceitos ou princípios que têm norteado a construção participativa de uma metodologia de gestão de planejamento e de terra, bem como estratégias para o monitoramento e avaliação dos planos de vida comunitária.

Da defesa do território como um elemento constituinte da cultura e como condição essencial para alcançar a autonomia, o povo nasa vem exemplo um plano de vida da comunidade de desenvolvimento social integral de instituições próprias que permitem administrar a justiça no 
âmbito da jurisdição especial indígena e promover uma alternativa de governo no programa de administração pública local.

Alcançar mudanças significativas na composição e relação das forças do poder político, social e econômico locais, regionais e departamentais. Sobre a proposta do povo nasa de gestão e governação dos seus territórios coletivos encontra-se uma maneira de pensar e de viver que faz parte da visão de mundo de uma cultura desenvolvida por um povo ancestral ao longo da história.

Semelhante a um diálogo intercultural entre auto e o externo, que passa através do confronto das demandas do estado e suas políticas de desenvolvimento, com os princípios do projeto político da autonomia da organização indígena e as bases e os sentimentos mais profundos de sua visão de mundo. O fogão, como ele é chamado nas áreas rurais da Colômbia para o fogueira que são preparadas os alimentos, combate resfriado e congregar o riso das crianças, ansiedades de adultos e a memória dos ancestrais para compartilhar a palavra, tem uma particular relevância para os povos nasa, ocupam um papel central nas casas e reuniões comunitárias.

Em torno da fogueira na montagem das decisões de rejeição ou apoio às ações para empreender a Comunidade ou organização indígena. Compartilhe a palavra expressar apreciações que é julgada e avaliado a proposta para desenvolver, gerenciar a entender o que não tinha sido percebido. A chaminé é o espaço de reflexão e de orientação do indivíduo, família e decisões comunitárias.

Você entra as brasas e brasas da lareira existem pedras colocadas para segurar a comida culinária do recipiente e dirigir o fogo, devido a sua função não serve qualquer pedra, ou pode ser posicionado em qualquer lugar, nem de qualquer forma. Estas pedras são chamadas de tulpas, bases ou suportes. A nasa fazem uso da metáfora das quatro pedras que são a base do fogão e chamar esse "Tulpa" para se referir a princípios ou preceitos que orientam o processo organizacional. Nesta seção você abordarei cada destes tulpas apresentar proposta para a administração e gestão pública do coletivos territórios indígenas sua Assembléia pela vila da nasa.

O processo organizacional que sustenta a nasa de governo da Comunidade em cada um dos guardas e a nível local, regional e zonal tem quatro princípios fundamentais ou tulpas no qual é autonomia, território, cultura e unidade de fabricação de cerveja e agência. Unidade, o território, cultura e autonomia como tulpas ou suporta o processo organizacional que permitiu que as pessoas 
nasa permanece como aldeia ancestral, são um termo que vem desde os dias do cacique Quilo e clássicos e Juan Tama, sendo outro exemplo de sua historicidade.

\subsubsection{A Tulpa da unidade}

Através de várias atividades de comunidade é tulpa gerado da unidade, entre as ações avançadas é encontrado mingas, um esforço ou trabalho coletivo muito comum nas comunidades de povos indígenas andinos da Colômbia, geralmente em cada um dos guardas é feito um dia por semana um minga envolvendo as famílias dos distritos representados por um ou mais dos seus membros para realizar trabalhos de benefício coletivo na calçada, o enredo ou fazenda comunal, mingas faz parte da solidariedade que tece as relações dos comuneros.

Em muitas ocasiões o mingas liga-se aos guardas regionais, zonais e locais para rotativas trabalho buscando o bem estar geral. Mas minga é simplesmente não é um trabalho coletivo, é uma ocasião para reunião e encontro com a Comunidade, que despões da jornada de trabalho é compartilhada uma refeição e torna-se uma reunião onde todos devem participar para avaliar e agendar tarefas, discutir questões de interesse comum, resolver problemas ou simplesmente conversar.

Essa concepção do minga como reunião ou partilha fortalece e reafirma a unidade da Comunidade. Para o pesquisador social Rubén Darío Espinoza que acompanharam solidariamente o organizacional processar nasa desde os anos oitenta do século XX e atingir quem entrevista na oficina de formação política ditada pelos jovens do ensino secundário básico e professores do programa da Comunidade etno-educação nas instalações da CECIDIC no abrigo de San Francisco no final de outubro de 2014 ,

A Minga, como trabalho, tem também o sentido de propriedade, no lugar que é feito, apropriar-se ou reafirmar sobre alguma coisa, mostrar que é proprietário e que todos são proprietários, não poucos. Por este motivo muitos projetos ou programas da organização é feito em minga, como uma forma de reafirmar que é tudo, e não de poucos, é não só seus empregados, funcionários ou dirigentes. O minga, é o lugar para conversar, conversar, fazer piadas, reconhecer uns aos outros, socializar. Duro resiste ao seu charme, é um divertimento, é parte da vida, agradável, do rico ao vivo. Por 
isso é uma necessidade vital (entrevista com Ruben Dario Espinosa, nas instalações da CECIDIC, abrigo de San Francisco. Outubro de 2014).

Como o minga, existem outras formas de comunidade como a troca de trabalho entre famílias ou comunidade trabalho Membros listado por bairro ou compradas go. Esta forma de trabalho olhando para maximizar o desempenho de atividades ou trabalho, reafirmando o sentimento e o espírito do trabalho coletivo como base para a unidade da Comunidade e a organização.

Módulos (assemblies), bem como mingas propício à reunião e reforça o sentido de filiação a uma coletividade, nestes espaços é relatado, analisa e faz decisões sob o princípio que tão bem como todos trabalham juntos, todo mundo tem o direito de ser informado e participar em decisão fazendo, refletindo, fazendo propostas e rejeitar ou apoiar as medidas que serão tomadas coletivamente.

Durante o ano muitos assembleis são feitos por programas e grupos de conselhos, municipais, local, geral ou Congresso, que integra todos os guardas da organização indígena. Estas são giradas por calçadas, para que a Comunidade terá a oportunidade de participar em algum momento, as autoridades tradicionais assistir todos ou grande parte deles para a sua posição ou função. Nas assembleias envolveram homens, mulheres, crianças, idosos, jovens, funcionários, dirigentes e funcionários do mesmo nível, sem distinção e parte do sentimento da organização indígena.

O minga e assembleis permitem recuperar e fortalecer o tecido social comunitário do recibo, o município e região. Mingas e módulos (assembleis) também se tornaram emblemáticas para os povos indígenas e sociedade nacional ser enquadrado em importantes processos de mobilização. Nos últimos anos a nasa ter decisões importante e seguindo as instruções das respectivas autoridades tradicionais no exercício da autonomia que tem a autoridade de ter encenado principais ações de controle territorial e a administração da justiça indígena através de mingas de desmilitarização do território e exercer seus próprio direito assembleis.

Considerando que a presença dele está colocando em risco a integridade da comunidade indígena desenvolvida operação militar nos territórios em violação do direito internacional humanitário, as pessoas nasa decide em junho de 2012 te perguntar mais uma vez para o exército e a polícia nacional a retirada militar as bases existentes no município de Toribío. Um mês após a 
recusa das forças armadas, a população de resguardos os três decide convocar uma minga desmilitar território, enfocando o desmantelamento da base militar do exército em Berlim, lugar sagrado do Monte cosmovicion nasa.

Em novembro de 2014 o insurgente grupo das forças armadas da Colômbia-FARC, assassinos dois guardas indígenas para ser encontravam, removendo uma vedação de propaganda alusiva à comemoração do terceiro ano da morte do comandante das FARC, aliás Alfonso Cano. Graças a mobilização rápida e coordenada da Comunidade foi a captura do esquadrão insurgente que cometeu os assassinato.

Cuatro dias mais tarde, no exercício da jurisdição especial indígena é convocada para um Assembly para a administração da justiça em si, que é julgada e condenada a sete guerrilheiros que admitiu ter participado no assassinato de dois guardas indígenas da nasa. Mais de 2.000 moradores que decretaram o Freehand frases de 60 anos de prisão para o autor do crime duplo e 40 anos para cada um dos quatro adultos que estavam com ele estavam envolvidos nesta casa.

Os dois guerrilheiros restantes, de 14 a 17 anos, receberam vinte chicotadas e serão admitidos para um centro de reabilitação até a idade adulta mingas e assembleis, foram algumas das mais importantes estratégias de mobilização na recuperação do território e dos conselhos nos anos 60-70, que permitiu a reapropriação de terras usurpados pelos proprietários e lidar com o processo de colonização e expansão da agroindústria. Criação de novos vínculos de unidade para trabalhar juntos a terra recuperada, estabelecendo-se novas aldeias entre grandes famílias do mesmo sobrenome vem do mesmo lugar ou famílias diferentes com outros sobrenomes de vários lugares, reconstruindo e reforçando o recibo e o cabildo como instituições comunitárias.

Neste modo o minga e assembleis como espaços de encontro, Comunidade e o trabalho de mobilização gestar e amarrados juntos, a tulpa ou o princípio organizacional da unidade.

\subsubsection{A Tulpa da cultura}

Cultura como outro tulpa ou pilar do processo organizacional da nasa e outros povos andinos, do departamento de Cauca como o denim, está envolvido em tudo o que eles fazem em suas vidas cotidianas.

Cultura é o nosso pensamento, nossa visão de mundo, nossos costumes e valores, nossa maneira de ser para nós. Este conceito se afasta aqueles que 
apenas vêem a cultura como as manifestações artísticas: música, dança, pintura, literatura, etc. Sem ignorar que esses são aspectos importantes da cultura (Cabildo, padres e Comissão sobre o trabalho do povo Guambiano 1994, p. 92).

Neste sentido, a cultura é a identidade de pessoas nasa manifestada nos sobrenomes, tradições ancestrais, a história coletiva do território que recria a língua idosa, própria, maneiras de agir, pensar e sentir que ele configura as realidades e diferente de outros desejos de comunidades ou povos. Elementos que caracterizam em maior ou menor grau para cada pessoa, mas que são reconhecidos como parte do que constitui sua identidade comum étnica historicidade, como povo e como cultura.

Daí a importância que tem para a reafirmação da nasa indígenas da diferença cultural, tornando a sociedade nacional e o estado, reconhecer seus valores e direitos, empoderandose de fontes externas para obter o reconhecimento de um próprio, a partir da reafirmação de sua identidade e os valores da inter-relação com as culturas externas, locais e do estado.

O que tem permitido a fontes externas adequadas para fundamentar e tornar o que reconhece seu próprio modo de vida, tão diferente do que o estabelecido oficialmente a todos os nacionais, mas para a organização indígena é garantia de bem-estar e permanência como povo e como cultura. Este processo de reafirmação do self é dinamizado pela promoção, recuperação e reivencion de cultural ligada à visão do mundo da nasa, das instituições e autoridades próprias, através de atividades e iniciativas que as práticas de agência.

A reafirmação de que o mesmo ocorre no desenvolvimento da comunidade indígena, organizando o projeto político autónomo, de diferentes maneiras e em inter-relação com fontes externas, em termos de estado e outros setores sociais.

Em meio as relações ineteretnicas do povo da nasa reforçou as formas tradicionais de controle e defesa do território, o projeto político da organização, os princípios e práticas de utilização tradicional e usufruto dos recursos, modos de economia de produção e Comunidade, mas por sua vez incorporadas práticas fora de sua cultura. Ruben Dario Espinosa (2003) pesquisador social para reafirmar a identidade local em interação com o externo e o estado,

É principais comunidades para estabelecer, não somente, novas regras do jogo no país, mas também, para entender e tirar proveito dos valores 
externos e outras culturas, assim, recriando suas próprias e reforçar o seu próprio caminho, através da incrporacion de novas práticas em correspondência com a visão de mundo da nasa (ESPINOSA, 2003, p. 23).

Esta forma de reafirmar a identidade da inter-relação e conforntacion com o externo, permitiu a recuperação e fortalecer reincorporar e valores tradicionais ou reconstruir pratica novos em correspondência com a própria visão de mundo.

\subsubsection{O território como Tulpa organizacional}

O território é um elemento constitutivo do povo nasa, graças a ele, foram capazes de preservar e recriar sua identidade cultural. Os territórios indígenas nasa de Toribio tem uma série de características relacionadas com a posse e terra coletiva do título colonial, inclui Propriedade cultural e simbólica que tem a visão do mundo da nasa e da importância económica e política, devido à sua localização geográfica estratégica. Proporcionando-lhe o espaço de nasa pessoas físico e simbólico para gestar e recriar uma identidade étnica.

Também deu-lhe um lugar de produção comum, para que têm sido coletivamente definidos pelo seu uso e gestão. Características que permitiram que permanece e prevalece a concepção cultural do território, sendo o local para o desenvolvimento da autonomia, que permite a existência da dinâmica da Comunidade que garantiam a existência do povo da nasa e cultura.

Para os povos indígenas e camponeses em geral e a nasa em particular, há uma crença de que o território é habitado é uma entidade viva, um ser incompleto que é complementado com as qualidades dos seres que nele habitam, que por sua vez, fazem a mesma coisa com o território. Em animais vivos, plantas, minerais e seres humanos com os espíritos que o acompanham. Então um o wala explicou no final de uma comunidade trabalho minga na calçada da guarda de Santa Anita, San Francisco para a construção de uma instituição educacional (aldeia tradicional médico da nasa).

A lei indígena natural que cada relação de membros da Comunidade com a terra deve ser permanente e abrangente. Desta forma, pode haver nenhum território indígena, nem território indígena, porque todas as coisas que estão na necessidade território uns aos outros, se complementam entre se e por que se relacionam, um corresponde ao outro e ajudar, não posso viver sem o outro (intervenção de uma o wala na minga do trabalho da 
Comunidade do dia 20 de setembro de 2014 na calçada da guarda de San Francisco Santa Anita da) Município de Toribío)

Comunidade nasa está ligada ao território por uma cultura e uma visão comum da vida, portanto, ao processo organizacional é tão importante o pé de uma construção de identidade territorial comum, através do diálogo ou confronto de práticas diferentes ou maneiras de ver a relação com a terra e o espaço territorial.

Da colônia quando cacique Quilo Sico peço a tiutlacion de propriedade coletiva e delimitação dos três abrigos Toribio, apelando para o direito constitudinario de origem, o território tem sido garantia de permanência e bem-estar como aldeia ancestral. Esta relação integral com o território, sustenta o direito de controlá-lo por conta própria, decide sua ocupação e o destino de seus recursos.

Nesta perspectiva, administração territorial étnica é exercida de acordo com sua própria institucionalidade, decisões de forma, participar, legislar, juiz, controle e produzir bens e serviços. Controle de comunidade e apropriação do território, a propriedade coletiva da terra, trabalho, ordenamento e defesa da Comunidade do território, é a reafirmação dos princípios da etnia de interrelação que permitem uma harmônica convivência com seres espirituais e materiais que habitam o território.

\subsubsection{Autonomia a tulpa que orienta o projeto significou Politico}

E alcance da autonomia como o tulpa ou suporte que define o projeto político da organização, está relacionada com as fases da história recente indígenas das relações interétnicas da aldeia da nasa.

Na década de 1960-1970, durante o processo de recuperação de terras, a reconstrução dos guardas e reforço do cabildo como própria autoridade dentro dele. Autonomia foi ligada para a recuperação da posse e controle da Comunidade do território ancestral. Capacidade de governar seu território de instituições e práticas comunidade própria, que era necessário ter uma organização forte, composta por comunidades dispostas a participação e mobilização com outros movimentos e setores sociais populares para atingir objetivos comuns. Para a década de 1980 quando a Comunidade nasa irá encontrar a desenvolver planos de vida comunitária para consolidar os processos de desenvolvimento social que procurava atender às necessidades básicas e implementar a plataforma industrial da organização indígena. Autonomia é a capacidade de formular, gerir e 
implementar planos, programas e projetos sociais integrante incentivo que as necessidades e situações do cotidiano da Comunidade.

Já na última década do século $\mathrm{XX}$, com as reformas constitucionais que dão a povos indígenas diferencial cultural de direitos em relação a administração de seu território, de acordo com suas tradições e costumes, a autonomia foi encontrada para ser ligada à gestão comunitária dos recursos próprios transferidos pela nação, orçamento participativo da administração pública local eleitoral político participação e comunidade implementação de projetos económicos e investimento social.

Foi também um período de integração territorial e administrativa dos guardas do norte do Cauca para fortalecer uma vida comunitária com plano zonal programas, consolidando uma desenvolvimento de proposta ou de bem-estar, a fim de garantir sua permanência como etnia e cultura. É a hora da luta para fazer as próprias instituições contra as instituições oficiais no local ou municipal, da luta legal para reconhecimento de estado do self.

A realização da autonomia será vinculada à capacidade de criar uma economia, gerenciar recursos aferidos e gerenciá-los com a participação e o controle da Comunidade, como garantia de boa gestão. Autonomia como um tulpa ou princípio organizador será a consolidação de uma proposta de vida digna para essa parte dos pontos de vista e interesses da nasa.

A partir do século XXI o ressurgimento do conflito armado no município de Toribío, faz com que a nasa no exercício da sua autonomia para tomar uma posição clara e definitiva contra a presença das forças armadas (polícia e exército) e insurgência em seus territórios.

Partir deste tempo até a hora que a nasa já deixou claro sua posição política e a diferença ou consistente com outras posições daqueles que são contra o sistema dominante no país, ou que aqueles que defendem a ordem estabelecida. É importante salientar que a noção de autonomia mencionada em períodos diferentes não é linear, conforme descrito, na verdade se misturam durante todos os momentos do processo organizacional.

As ações e iniciativas de cada um dos períodos que sustenta a noção de autonomia, ainda estão desenvolvendo e consolidando a um maior ou menor grau, muitas dessas ações apropriado como local constantes do processo e diretrizes do projeto político da organização, que define a autonomia como tulpa ou princípio da aldeia da nasa da organização. 
Essas tulpas ou princípios organizacionais baseiam-se a visão de mundo das pessoas nasa que se refere a um dever ser que subjaz por que são as coisas de uma certa maneira. Sendo o parâmetro que é avalia a externos ou diferentes e se concentra sua dotação em conformidade com o que deveria ser. Você deve ser, de acordo com o filósofo Estermann (1998) "não é tanto uma reflexão sobre as normas de comportamento humano, mas sobre seu ser dentro do cosmos... pensamento indígena é mais um pensamento, sendo que de si mesmo, ou seja, da realização da existência" (ESTERMANN, 1998, p. 226).

É identificação com um modo de ser e que ele é orientado por costumes, tradições, mitos e crenças que fazem referência a uma cultura nativa ou ancestral. $\mathrm{O}$ primeiro princípio da visão de mundo das pessoas a nasa é a relação de todas as entidades que povoam o cosmo. Desde que tudo no universo existem como matéria e espírito relacionados, lá nada desencaixada juntos, nada é desanexado em tudo e tudo é dado de diferentes relações. Desta forma, explica a intervenção wala (médico tradicional) mencionada anteriormente

As plantas curam não só pelos seus componentes, mas também pela força que têm, ou melhor, por seus espíritos. Tudo é submetido a uma correlação de forças, o equilíbrio do seu espírito. Os espíritos de cada pessoa estão relacionados com todos os espíritos neste espaço e destacados. Equilíbrio não é um estado em si, mas uma correlação dinâmica constante da força em harmonia, não há nenhum bem, nem mal absoluto, ele procurou e desejou é viver em harmonia ou equilíbrio, porque é tão importante tornarse permanentemente para o refresco de harmonização (intervenção de uma o wala na minga do trabalho da Comunidade do dia 20 de setembro de 2014 na calçada do el de San Francisco de Santa Anita Municipio de Toribío guarda).

Urbanidade inteiramente como um princípio básico da vida do povo da nasa, é derivado de complementaridade, reciprocidade e a correspondência como base da sua forma de viver e estar no mundo, no que se refere a wala menciona que

todos os seres estão relacionados porque cada um é um incompleto sendo, você precisa se juntar a outros para ser concluída, são como as partes que necessitam de integração; Tenho qualidades que não tem e os outros, por 
sua vez, tem qualidades que eu tenho; Preciso de outros para viver, crescer, pensar, decidir, trabalhar. Se o outro me complementa, deve complementar o outro, portanto, reciprocidade; Se um me ajuda no meu trabalho, por sua vez deve ajudá-lo em seu trabalho, que é a correspondência que nos torna um comum nos integra (intervenção de uma o wala na minga do trabalho da Comunidade do dia 20 de setembro de 2014 no resguardo de San Francisco de Santa Anita Município de Toribío.)

\subsection{Administração e governança local indígena, no município de Toribío}

A estrutura do processo de descentralização da administração pública fornece a eleição popular das autoridades locais para fortalecer os governos municipais e departamentais com a gestão dos recursos de investimento social nacional. Antes, quando prefeitos de autoridades municipais foram nomeados pela autoridade departamental, que, por sua vez, foram nomeados pelo governo nacional.

Com as mudanças na administração local e departamental, as comunidades indígenas de Cauca em geral e a nasa em particular começam a participar ativamente na eleição popular de prefeitos e câmaras municipais. Participação na administração pública local tem sido uma importante estratégia do município de pessoas Toribio nasa para reforçar o processo organizacional e impulsionar seu plano de vida comunitária, o epicentro dos processos de descentralização e a exigibilidade dos direitos culturalmente distintos concedida aos povos indígenas em relação a administração de seus territórios, de acordo com suas tradições e costumes são os governos locais.

Como mostra a existência de uma forte organização local com uma cultura de participação da Comunidade no movimento cívico, Álvaro Ulcué, formada por três guardas da nasa comuneros de Toribio alcançou que você para o gabinete do prefeito e os vereadores foram eleitos representantes do exemplo de organização indígena a administração pública local da dinâmica para fortalecer a Comunidade para organizar o processo e suas iniciativas e práticas de um diálogo intercultural com instituições do estado e outros setores da sociedade nacional.

Para esta participação eleitoral do povo indígena nasa nas eleições locais tem sido que o Estado reconhece um movimento político, a fim de apoiar seus candidatos por conta própria. Movimentos cívicos e comitês políticos locais e regionais para a criação de parcerias entre organizações indígenas e outros setores sociais para a eleição de candidatos, para estabelecer 
estratégias na campanha eleitoral, definindo os programas de governo dos seus representantes e o apoio político que precisam Durante suas administrações foram criados.

Garantir o empoeiramento político a nível local e regional, com a participação regular nas eleições das autoridades locais que compõem as instituições de estado da administração pública, a fim de promover e manter a participação da Comunidade.

A participação da comunidade indígena de processo na administração local, através da eleição de prefeitos e vereadores que fazem parte e responde a organização indígena, foi a oportunidade para as instituições de estado locais apropriadas e colocá-lo para o serviço da vida comunitária plano nasa, operativizando aduaneiro a exigibilidade dos direitos culturais diferenciados relacionados à administração de seus territórios, de acordo com seus usos.

Facilitar a coordenação das ações das instituições do Estado Municipal e comunidade como ele contempla o processo de descentralização administrativa, mas também como demanda a vida comunitária plano da nasa. Com o que se conseguiu que a administração municipal com base em seu plano de desenvolvimento setorial sobre questões como a educação, saúde e gestão dos recursos naturais e economia, entre outras questões de programas e iniciativas, que faz parte da vida da Comunidade plano conhecido como projeto da Nasa.

Desde a eleição de candidatos, a elaboração do plano do governo e a execução e acompanhamento para o plano de desenvolvimento municipal, bem como a definição e avaliação de políticas e executórios assuntos públicos das decisões do governo municipal, planejando o investimento de recursos locais são realizadas nas configurações do tradicional comunidade tais como assembleis Você mingas e comissões constituídas pelo Conselho por meio de projetos comunitários. Incentiva a participação ativa da comunidade de diferentes espaços organizacionais na administração pública. Isto representa uma mudança importante na lógica do funcionamento das instituições de estado locais, caracteriza-se em grande medida pelo seu grau de altisismos de corrupção e ineficiência.

Desta forma estabeleceu uma ponte entre as instituições comunitárias tradicionais e instituições municipais do estado, que visa gerenciar o yuxtapocision das instituições no mesmo território, evitando a duplicação de funções e fazendo as instituições do estado é posta à serviço da comunidade de instituições tradicionais e seu plano de vida. 
O que não foi sem problemas e conflitos para a incapacidade da Constituição completa dos índios entidades territoriais como institutuciones de gestão e administração pública local, definindo suas competências na administração dos territórios indígenas. Tema que nós refiaremos de forma abrangente na próxima seção. Ezequiel Vitonás líder indígena para a Nasa, que foi eleito como presidente da Câmara Municipal de Toribío pela segunda vez para o período 2012-2015 e que tem sido apenas como governador do cabildo indígena de Tacueyó e conselheiro da Associação dos Cabildos indígenas do norte da Cauca-(ACIN).

As comunidades indígenas da cidade Toribío nasa tocado você encontrar suas próprias maneiras de organizar a exercer a autodeterminação, fora da instituição do município, administrações municipais desde a época da independência da Espanha, então nunca deu, nem permitida a participação das comunidades indígenas na definição da rota do município. Assim surgiu o abri em 1971 e o projeto da Nasa, com a participação da organização indígena no gabinete do prefeito pretende mudar a dinâmica da administração municipal local para colocá-lo ao serviço dos planos de vida das comunidades (entrevista com Ezequiel Vitonas no gabinete do prefeito do município de Toribio em setembro de 2014).

Sentido, como o povo os nasa expressa a 2012-2015 do município Toribío administração do plano de desenvolvimento concebido instituições locais do estado como um instrumento, uma ferramenta que deve estar ao serviço da autodeterminação das comunidades indígenas.

El Camino se ha tejido, nosotros y nosotras tenemos trabajar para continuarlo, es el tejido de la autonomía, y solo es posible bajo la libre determinación, bajo nuestra propia convicción de gobernarnos. Con este propósito está lo esta Alcaldía, es de todos y todas, no es más una herramienta del Plan de vida, el azadón o la pala del agricultor, de pronto un hilo de los tejedores y las tejedoras. Si el alcalde y su equipo de trabajo somos ese instrumento de la comunidad, habremos servido para algo. Las comunidades indígenas del Municipio entienden la administración municipal como un instrumento para la realización de su plan de vida. La alcaldía de Ezequiel Vitonas Tálaga, centros de este proceso, se reconoce 
como un medio que han adoptado la comunidades para facilitar su empoderamiento y revitalizar su plan de vida, accediendo con mayor facilidad a espacios y recursos. Al mismo tiempo, desarrollando el espíritu de las comunidades, su ejecución se realizará respetando los derechos de la población no indígena convive en el municipio (PLAN DE DESARROLLO MUNICIPAL DE TORIBIO 2012-2015).

A participação dos povos indígenas da nasa na administração pública local, concebendo-o como um instrumento ou ferramenta para roubar o seu plano de vida comunitária, com base na dinâmica participativa de desenvolvimento social abrangente, revela um mal entendido e contradição entre a visão, concepção e pretensões do processo de descentralização administrativa promovida pelo Estado e os processos de autonomia preconizada pela organização indígena que busca a exigibilidade dos direitos culturais diferenciados, associados com a administração dos territórios indígenas, de acordo com suas tradições e costumes.

Enquanto grupos étnicos comprometeram com o fortalecimento dos mecanismos e esquemas de comunidade participativa dos governos, o estado promove políticas e medidas favoráveis ao desenvolvimento e consolidação dos processos de autonomia local.

\subsection{Justaposição institucional e inter-étnico atritos na administração e governação dos territórios indígenas do município de Toribío}

Sendo composta por guardas do município Toribío em Tacueyó, San Francisco e Toribío, reconhecidas pelo Estado como as entidades públicas de caráter especial e transitório para governar os territórios indígenas em coordenação com as instituições de estado locais, regionais e nacionais de unidades territoriais surge uma dualidade e justaposição na gestão e administração pública local, resultando em mal-entendidos Você colisões e etnias fricções que tornar inteligível o caráter antagônico das formas de pensar e governar o território pelo povo da nasa e o Estado colombiano.

Situações que revelam as relações de poder assimétricas que compõem a estrutura do sistema interétnico que é parte do exercício dos direitos culturais diferenciais concedido aos povos indígenas pela Constituição multicultural de 1991. Direitos que o estado restringiu seu potencial integrador, como parte de um processo de articulação social geral, no qual a natureza antagônica dessas relações, supõe um sistema interétnico consistindo de mecanismos de conjunta onde houver um conflito manifesto ou latente na situação de coexistência de diferentes práticas culturais, dentro 
de um espaço territorial em sua implementação, "entre duas populações dialeticamente unificadas através de interesses diametralmente opostos, mas paradoxalmente interdependentes" (CARDOSO OLIVEIRA, 1981, p. 26).

Estas situações de fricção interétnica na administração e governação dos territórios indígenas coletivas, adquirir um relevante superior em municípios como Toribio, onde a população é maioritariamente indígenas e tem vasta experiência e capacidade organizacional.

A participação da organização indígena na administração pública local de programas de governo, desenvolvido e implementado coletivamente através de diferentes práticas, projetos e dinâmica da Comunidade do povo da nasa, tem facilitado a coordenação das instituições de estado locais e conselhos para a execução das receitas do sistema geral de participação-GSP.

No entanto, uma série de conflitos relacionados com a natureza da ordem política administrativa de centralista e natureza neoliberal da estrutura institucional do Estado colombiano são persistentes. O que tem impedido o estabelecimento completo de entidades territoriais indígenas como instituições de gestão e administração pública local, definindo suas competências na administração dos territórios indígenas. Nesta última seção eu focar as divergências, conflitos ou cinemática que considero nesta dissertação como fricções interétnicas apresentam na administração e governança do município de Toribío.

A participação da organização indígena na administração pública local de programas de governo, desenvolvido e implementado coletivamente através de diferentes práticas, projetos e dinâmica da Comunidade do povo da nasa, tem facilitado a coordenação das instituições de estado locais e conselhos para a execução das receitas do sistema geral de participação-GSP.

No entanto, uma série de conflitos relacionados com a natureza da ordem política administrativa de centralista e natureza neoliberal da estrutura institucional do Estado colombiano são persistentes. O que tem impedido o estabelecimento completo de entidades territoriais indígenas como institutuciones de gestão e administração pública local, definindo suas competências na administração dos territórios indígenas. Nesta última seção eu focar as divergências, conflitos ou cinemática que considero nesta dissertação como fricções interétnicas apresentam na administração e governança do município de Toribío.

O estado através do departamento administrativo nacional de estatística-DANE definido e projeto, no censo de 2005, o número de habitantes de territórios indígenas na Colômbia. Sem, no 
entanto, estes dados não concordar com aqueles obtidos nos censos recentes realizados autonomamente pelos conselhos indígenas do município de Toribío.

Enquanto para as projeções feitas pelo censo de 2005 o número de habitantes de Toribío para junho de 2013 era de 28561 pessoas no censo realizado pelos conselhos para a 24 de abril de 2013 teve 32676, que representa uma diferença de 4115 pessoas, 14\% de diferença entre os dois censos, uma percentagem considerável da população base que deve definir o orçamento para ser entregue para o resguardos para administração e gestão pública de seus territórios.

Para Gilberto Muñoz ex-prefeito dos municípios de Toribío e Miranda, bem como ex secretária da educação, departamentais e candidato para o cargo de governador pelo movement(MAIS) alternativa social indígena de Cauca, entrevistado durante a sua participação na Assembleia da Associação dos conselhos indígenas do município de Toribío-projeto da Nasa, realizada nas instalações do CECIDIC no abrigo de San Francisco. A diferença dos recenseamentos, conforme reconhecido pelo Estado como povos indígenas é não só um debate ou questão técnica, uma vez que é uma questão política que faz parte do regime de tutela que o estado impôs-se à gestão dos territórios indígenas, para limitar a capacidade orçamental ou fiscal de governos indígenas, ignorando o crescimento demográfico dos resguardos.

Um dos problemas de descentralização é que eles querem essa categoria 6 [crianças] municípios e conselhos de fazem as coisas quando não temos os recursos, nem as condições. Critério de recursos é o número da população registrado na guarda, mas é o governo que nos diz quantos somos através do DANE e fornece essas informações para o planejamento e o Ministério do Interior, e informações que tem conselhos não são válidas para eles. E planeamento nacional não tem os dados reais de quanto é a população indígena do país. Você não tem! Então, por exemplo, em Toribío [município de Cauca], DANE diz há 28561 indígenas e Conselho argumenta que são 32676, primeira inconsistência. Então é a mesma em todos os municípios, todos (entrevista com Gilberto Muñoz, antigo prefeito de Toribío, de novembro de 2014).

Outros itens que mais polêmica que gerou nas condições de ligação dos guardas do município de Toribio de participation-(SGP), General sistema é de orientação estratégica que dá a 
direção de assuntos indígenas do Ministério do interior e do departamento de community-(DPN) nacional de recursos designados.

Uma vez que são os critérios políticos de que os órgãos de controlo fiscais avaliar os conselhos administrativos fazem os recursos transferidos para os guardas. Para Ezequiel Vitonás prefeito de Toribío para um segundo mandato e com uma longa carreira como uma autoridade tradicional de várias organizações e instituições indígenas zonais, regionais e locais.

A prioriorizacion do investimento dos recursos do SPG em 5 setores que lei 715 não faz assim em outros lugares identificaram como prioritários pelas comunidades, mas limitando-as para avaliar somente aqueles definidos a nível nacional. Por que muitas vezes consideram fiscal órgãos apresentou um desvio ou má gestão dos recursos quando estes são investidos em diferentes áreas que recomendas-los pelas orientações do departamento de planeamento nacional.

Do Norte del Cauca, ACIN deu algumas discussões e o fiscal do mesmo e o procurador-geral por meio de circular diz que a palavra priorizada não faz uso dos recursos transferidos para os guardas em outros setores, é por isso que no Norte del Cauca não só é feito o investimento em cinco sectores, também têm fatos nos diferentes programas e projetos que têm os resguardos.

Já tivemos muitas discussões, porque apesar do conceito do procuradorgeral e a Controladoria, planejamento nacional não teve isso em conta e quando pagamos os relatórios para esta instância do controle, nós podemos fazer apenas cinco setores estabelecidos em formatos não-modificáveis e outros nos fica do lado de fora, pelo qual apresentamos anexos aos relatórios onde percebemos o investimento de recursos em outros setores. Mas quando chegarem os resultados do monitoramento e controle do investimento dos recursos que temos desvantagens porque dizem-nos que para o desvio de recursos ou tem má gestão dos recursos.

Então falamos de autonomia, mas na realidade não temos quando o artigo 87, da viola lei 715 esta autonomia nos dizer como e precisa investir os recursos entregues. Por que, mas podemos seguir as diretrizes de primers DNP orientancion, são credores de sanções administrativas, fiscais e 
penais. Eu estive nessa situação como prefeito, governador e concejero principal ACÍN (entrevista com Ezequiel Vitonás no gabinete do prefeito do município de Toribío em setembro de 2014).

Para prefeitos e organizações indígenas responsáveis pela administração dos recursos de transferências GSP, esquema de controle de recursos tecnocrática estabelece uma limitação da autonomia dos governos locais, para fazê-lo para responder por requerimentos que impede ou limita a execução de atribuído rubricas orçamentais. Neste sentido, o ex prefeito de Toribío Gilberto Muñoz menciona o seguinte

Quando eu era prefeito de Toribío invertíamos em várias coisas, aqueles financiados por transferência é continência o investimento dos municípios, porque o problema da administração pública local é que municípios menores (categoria 6) nos supeditam a utorizacion do uso dos recursos fiscais para uma série de exigências que nos são difíceis de respeitá-las, por que os conselhos de co-financiamento. A lei 715 obriga-na apresentar o programa de projetos de investimento para financiar, por exemplo, para fazer uma escola nos exigem um estudo preliminar, um design e requisitos gerados pelos gastos, mas o co-financiamento não são cobertos pela lei (entrevista com Gilberto Muñoz, antigo prefeito de Toribío, de novembro de 2014).

Para estas situações e a ausência de uma lei de indígena que constituem entidades territoriais completa e regular a sua administração, ver Gilberto Muñoz, antigo prefeito de Toribío aquilo que tem prevalecido na administração pública nos territórios indígenas é ignorância e interpretação divergente das leis e procedimentos relacionados com a aplicação dos recursos da dotação especial da participação sistema geral para o Resguardos indígena-AESGPRI.

Depois, há muita ignorância de todas as partes, a ignorância dos regulamentos por parte das autoridades indígenas, mas também a ignorância das leis indígenas pelo Estado, falta de conhecimento da falta [constitucional], de decretos regulamentares tribunal acórdãos. Daí o medo também, medo que de repente eu e ir para a cadeia, medo de que eu fiz isso como era e então julgou. Essa também é uma realidade. Então a contradição 
na interpretação jurídica. Cada um interpreta a lei em sua própria maneira, interpreta o escritório do procurador geral, interpreta o escritório da Controladoria, interpreta o advogado do prefeito escritório interpreta o planejamento do prefeito, interpreta o planejamento departamental, e temos os conceitos de planeamento nacional. E então começa todo mundo admira, e então o que fazemos? (Entrevista com Gilberto Muñoz, antigo prefeito de Toribío, de novembro de 2014).

Como podemos ver no testemunho deste ex-prefeito que também tem sido a autoridade tradicional e membro do Conselho Municipal dos municípios que governou como prefeito, obviamente, a dispersão de informação e desarmonia interpretativa sobre processos operacionais relacionadas com a aplicação do AESGPRI.

Tecnocraticos reguladoras de quadros e esquemas que regulam a participação dos guardas indígena GSP determina que DNP e departamentos têm a responsabilidade de treinar, aconselhar e assistir tecnicamente os municípios e conselhos indígenas na elaboração dos planos de desenvolvimento e projetos a financiar com os recursos transferidos para a administração dos territórios indígenas.

Neste treinamento ou consultoria revelou a divergência existente entre a proposta administração e gestão pública dos povos indígenas e as alegações de que o estado com o processo de descentralização neoliberal nesse quadro guarda vinculação SPG. De acordo com o que é expresso pelos membros da reserva indígena de Toribío estes treinamentos são executados sob uma orientação teórica e conceitual que não mantém qualquer relação com as estruturas habituais das culturas indígenas. Essa concepção de planejamento, organização e práticas de gestão do território que comunidades indígenas feitas no quadro da figura conhecidas como vida planos de entrar em colisão.

Você não é precisamente "planos de desenvolvimento", como administrações municipais, departamentais e nacional de fabricantes. Planos de vida são a carta de navegação coletiva que dirige a articulação da vida dos povos indígenas. Estes são construídos a partir de práticas de comunidade onde as iniciativas e propostas de programas, comissões, conselhos, associações ou grupos que coletivamente os povos indígenas da Agência são coletados. 
Para os moradores e autoridades indígenas nasa técnicas de orientação fornecida pelo departamento nacional de planeacion DNP), de uma perspectiva neoliberal procura que os povos indígenas aceitam e interiorizar o discurso dominante de desenvolvimento e os usos e costumes das comunidades adaptar-se a esquemas institucionais e governo interpretação dos direitos concedidos ao reconhecimento da diversidade étnica e cultural. Causando uma divergência na aplicação dos regimes de institucional tecnocrática das políticas de reconhecimento multicultural.

Devido a isso a nasa concebem integrando suas instituições e projetos comunitários de gestão e administração pública local estado de um processo vingativo que visa mudar a correlação de forças econômicas e políticas a nível local, regional e nacional. Esta divergência em torno de noções e as pretensões do treinamento fornecido para a gestão dos recursos transferidos para os guardas, localizado seu epicentro na redução do planejamento para o cumprimento pelas comunidades de algumas exigências burocráticas, destinado a fornecer informações que justifiquem a liberação de recursos financeiros que serão utilizados na realização de determinadas atividades específicas

A informação requerida está dentro dos parâmetros definidos pelo governo central para orientar o investimento de recursos transferidos, que define o que é aceitável. Então vai descobrir que as comunidades adotem esses jogo regras e restringir-se para propor atividades no quadro dos parâmetros que aceitam o estado e suas instituições de controle. Neste sentido, o item e orientação determinou-se o estado para o planejamento e a utilização dos recursos, dado aos guardas é divergente da proposta chegar a comunidade de gestão através de seus planos de vida comunitária, em que questões como saúde e educação não podem ser vistos como simples produtos ou itens de burocráticos de papelada que são reduzidos para a prestação de um serviço que visa garantir um direito. Para o atual presidente da Câmara Municipal de Ezequiel Vitonás, discussão de territoriais relacionados com indígenas de diferentes direitos culturais ultrapassa em muito o campo operatório.

Esse assunto, já trabalhou em várias palestras regionais e zonais da ACIN desde o abri, identificando problemas ou conflitos e também trabalhando algumas alternativas. Porque no governo há várias interpretações para o gênero plano nacional de desenvolvimento (2010-2014), [...] porque eles estavam anteriormente perfis de projeto, agora tenho que ser projetos, 
tecnicamente formulados, em seguida, surge uma dificuldade e uma exigência no mercado interno das comunidades. O que se presume é que o restante do ley1450 [plano nacional de desenvolvimento do Presidente Santos] sobre este assunto, planejamento certamente nacional terá que projetar outro instrutivo com outros procedimentos. E isso é uma outra situação, o que é que a atual Diretiva 2001 não corresponde com as modificações para as transferências de indígenas que foram acordadas no plano nacional de desenvolvimento. Como prefeito e autoridade indígena pergunto-me se as instruções ou manuais de DPN são como uma lei? É obrigatório? Estão acima da Constituição? Por este organizações indígenas de razão, decidimos que como autoridades tradicionais também produzimos um conjunto de instruções para nossos usos e costumes, procurando a sua harmonização com o padrão do estado. Porque eu acredito que estamos diante de um desafio para um desafio grande o suficiente, deve reforçar a gestão de equipamentos e planejamento a nível dos diferentes territórios, diferentes áreas para efeitos da administração desses recursos, ou aqueles que vêm de cooperação, porque a situação exigir. Também porque este é o caminho para o estabelecimento completo do ETIS se estamos lá porque temos que criar o condições administrativas, políticas para esse exercício. Só tens de ver se é um ETIS pela recepção, pelo município, pelos povos indígenas, por área ou fará uma grande ETIS a nível de Cauca. (Entrevista de Ezequiel Vitonás no gabinete do prefeito do município de Toribío em setembro de 2014).

A declaração do Ex-prefeito de Vitonás identifica o questionamento que fazem os povos indígenas de Cauca à interpretação técnica fazendo direito planejamento nacional 715 e promovido através de seus textos visando orientar as cabildos em referência a execução e planejamento de recursos AESGPRI. Da mesma forma, revela algumas das principais questões existentes nas comunidades indígenas e para o interior da administração municipal em referência o processo de planejamento e implementação de recursos do AESGPRI.

Baseado na experiência da comunidade indígena do governo do município de Toribío, aplicabilidade e implementação de diferenciais direitos culturais relacionadas com a administração 
dos territórios indígenas, de acordo com suas tradições e costumes que a alocação de recursos do sistema geral de participação é parte dos guardas como entidades territoriais especiais de natureza transitória.

Ele revela que a luta do povo nasa para autonomia conduz a uma proposta e a realidade da sociedade de construção com base em comunidades étnicas como sujeitos coletivos, que, nas actuais circunstâncias, chega a características específicas relacionadas com os conflitos existentes entre eles e o estado. Da sua sobrevivência coletiva como iniciativas de povos nativos, a nasa de Toribío desenvolveram uma maneira de ser, fazer e viver diferente do mediada pelas instituições do estado. O que permitiu-lhes a perceber as oportunidades de socialização e construção de subjetividades de relações sociais horizontais e emancipatórias em cenários de desigualdade social e confrontação armada onde a dominação é de formas vulgares de militarização e a exclusão.

Ele se pergunta ... e resistir às políticas governamentais, gerando alternativas de mecanismos de autodeterminação que constituem uma comunidade institucional que reivindica a autonomia do estado e contribuam para a desconstrução da ordem propuseram políticas e instituições predominantes. Gerados processos sociais de produção de sentido que vai para disputar os significados das práticas sociais, lutando com quem tem o poder de definir esses significados.

Que tem envolvido a reinvenção permanente da vida cotidiana para preservar suas tradições ligadas à cosmogonia e sentidos de comunidade. Colocando no lugar uma política cultural, que não está limitado a que são tradicionalmente considerado como práticas culturais - de acordo com Arturo Escobar, usa e costumes, mas que reconsidera as interpretações dominantes em termos de política e a orientação política, questionando a ordem institucional vigente.

O processo organizacional indígena Toribío conduziu-se a assuntos políticos e espaços de socialização que não se originam dentro das estruturas do estado e a lógica da sociedade moderna. Pelo contrário, eles são o produto de matrizes de processos práticos comunidade epistêmica. $\mathrm{Na}$ vida diária da Comunidade desenvolve práticas políticas subalternas e experiências de vida contra hegemônico que fazem parte do processo de subversão da reprodução do status quo, exemplo da vida quotidiana, uma nova realidade.

Desde como menciona a proclamação pública do Congresso indígena e popular que reúne consulta cívica e popular contra o acordo de comércio livre. "A vida é tudo que temos e é também tudo o que temos são e podem ser. A vida é para ser, em suas múltiplas e diversas formas e 
manifestações. " (Ver cidadão e popular contra o Tratado de livre comércio, 2004) Esta coesão social, cultural e política em torno da defesa de uma vida diferente do projeto do modelo dominante, o processo da comunidade indígena de Toribío nasa faz uma alternativa à ordem estabelecida desde o estado nacional.

A partir de suas iniciativas locais, que a Comunidade nasa interage com outros setores da sociedade colombiana, que se estão bem localizados socialmente, culturalmente e economicamente em diferentes realidades, compartilhar a busca de mudanças fundamentais emancipatórias.

Para organizar a convivência intercultural práticas não hegemonizam-te, de relações sociais, económicas e políticas com base na reciprocidade e na solidariedade. Com a proposta do governo da Comunidade dos povos nasa baseado em geradores princípios de unidade e articulação social, económica e política no âmbito das comunidades e com toda a sociedade sob as formas de representação, gestão e propriedade de seus territórios. Procura superar a inclusão de subordinante existente sob a estrutura dominante da nação estado e levar a uma abertura para a construção de um Estado multinacional e intercultural. Reafirmando a identidade cultural como povos indígenas sem causar uma ruptura com a identidade nacional da sociedade colombiana, para reivindicar a possibilidade de construir uma nação no âmbito de várias nacionalidades, com base em acordos, alianças e pactos de reciprocidade, em igualdade de condições e não como um processo de subalternização de inclusão ou de dominação.

Ao invés de ser colombianos somos povos indígenas diferentes para a empresa e outros gestores do nosso próprio processo. As tradições conservadoras e antigos valores culturais considerados Património Mundial da UNESCO de contribuir para a construção de uma nova Colômbia. Nós lutamos pela sobrevivência, unidade, solidariedade para com a autonomia econômica, política e cultural em busca de um desenvolvimento integral, (Cabildos indígenas del Norte de Cauca, 1999, p. 1).

A administração dos territórios indígenas do município de Toribío das instituições comunitárias e sua participação nas instituições de estado locais propõe um novo modelo de político organizacional, com base na autodeterminação y156respeto diferentes povos, permitindo a participação e diálogo de diferentes sistemas culturais na administração pública. 
Um novo quadro jurídico, legal e institucional para a interação do estado e das comunidades a dinâmica da administração e gestão pública dos territórios indígenas é configurado com as alterações legislativas da constituição de 1991 e participação nas eleições locais, regionais e nacionais.

No entanto, estas novas relações tem encontrado várias dificuldades e desafios relacionados com a tecnocracia imposta pelo Estado para a executividade ou implementação de diferenciais cultural os direitos concedidos pela constituição de comunidades étnicas multiculturais, porque a configuração e administração do estado é baseada em noções culturais, ao contrário do noções de povos antigos.

As relações entre as comunidades e o estado na sua gestão e governação dos territórios indígenas são contestadas, devido a que o estado pretende implementar leis, tratados ou acção administrativa que não coincide com a autodeterminação das comunidades. Esta situação permitena refletir sobre a relação entre o estado e as comunidades indígenas em contextos locais onde ambas as autoridades do estado como comunidade servem como atores de governo.

Contextos onde as realizações e as exigências da autonomia para as comunidades indígenas, entram em conflito com as intenções do Estado colombiano. Considerando as populações indígenas que estado eles estão violando os seus direitos e isso, para as reivindicações das comunidades impedem o cumprimento de suas funções constitucionais. Situação que ocorre devido a isso, apesar do reconhecimento constitucional da diversidade étnica e cultural, o pleno exercício dos direitos concedidos para as comunidades indígenas encontraram algumas dificuldades em instituições governamentais e agentes de estado, sendo parte de um sistema baseado em preceitos culturais eurocêntrico, contrariando idéias do próprio povo.

No entanto, a autonomia dos povos indígenas, como uma forma de vida ancestral, tecelagem de familiar, comunitária e espiritual de acordo com uma visão de mundo que se mantém até hoje, é um facto e não meramente um direito reconhecido ou concedido pelo Estado. Autonomia emerge como uma expressão concreta da resistência dos povos indígenas e a luta pela sua emancipação e autodeterminação da Comunidade, sendo a expressão da sua existência.

Não podemos e não vai esperar para o Congresso de legislar para a emissão de lei do ordenamento do território e regula a criação de entidades 
territoriais indígenas: porque ele não está interessado e se fez sabemos seria legislação para expropriar terra direitos a nós.

A Constituição estabelece que os territórios indígenas são entidades territoriales157de a República. Não precisamos de uma lei que reconhecelos, porque eles já são uma realidade jurídica e material. Convenção 169 da OIT e a declaração das Nações Unidas sobre os direitos dos povos indígenas também obriga o estado a reconhecer nossos territórios.

O segundo congresso de ACÍN envia imediatamente impulsionar nossa função legislativa territorial, para dar um quadro jurídico para o território indígena autônomo no norte de Cauca, desde a lei de origem e outras leis que reconhecem nossos direitos (mandato do Congresso indígena eu e Popular, setembro de 2004).

O caso do povo da nasa do abrigo de Toribío demonstra como a luta pela autodeterminação das comunidades indígenas não é exigir que as instituições do estado para cumprir as suas funções, mas que visa modificar a operação, lógica e fundamentos básicos do estado como uma instituição moderna. Para reivindicar a redefinição do estado-nação de acordo com a realidade intercultural da sociedade colombiana, propondo a criação de um novo modelo de política organizacional que garanta o pleno exercício dos direitos dos povos indígenas como uma coletividade política assuntos, entre os quais está a governar autonomamente seus territórios coletivos das suas tradições e costumes.

Como podemos ver no caso dos guardas de aldeia de Toribío, nasa de San Francisco e Tacueyó que compõem o município de Toribío, a participação dos povos indígenas no sistema de transferências os envolve uma série de esquemas regulamentado e controlado pelo governo, que revelam um pouco do ponto nodal conflitantes relações do estado e os povos indígenas do reconhecimento e aplicabilidade dos direitos inscritos para a territorialidade autodeterminação e governança indígena.

Desde regimes legais e institucionais que visam garantir a governabilidade dos territórios indígenas por meio de suas autoridades tradicionais tornaram-se novos mecanismos de dominação e de tutoria, em vez de possibilidades de reestruturação pluralista do estado, do reconhecimento das diferenças. Governo controle condicional exeqüibilidade dos direitos concedidos aos povos 
indígenas a uma interpretação que limita-los, superar a regulamentos e interesses, ao contrário do que eles. Estabelecer que Souza Lima (1995) chamado um grande "anel de paz", que visa uma aculturação respeitosa em termos de Jimeno e Triana (1985). Ou seja, uma adaptação dos usos e costumes dos povos indígenas aos regimes institucionais e interpretações do governo do estado.

As relações entre os povos indígenas e o estado em termos de governação dos territórios coletivos, tem características diferentes e interpretações sobre o exercício de cultural, territorial e autonomia administrativa reconhecida.

Presentando-se uma tendência de oposição e conflito nas declarações e procedimentos desenvolvidos pelas comunidades e o estado, note-se que as medidas, políticas e ações realizadas pelo governo são inconsciente e violam os direitos das Comunidades; Enquanto o estado percebido as demandas e as propostas de autonomia dos povos indígenas como um perigo para a estabilidade das instituições políticas do país.

Os limites estruturais e interpretações divergentes dos plurietnicos e direitos territoriais que revelam as tensões que surgiram como resultado da colisão de visões e práticas de governança dos povos indígenas e os espaços institucionais pelo Estado participarem na administração de seus territórios. Esta situação não só revela diferentes interpretações, mas também conceitos opôs-se sob a forma de pensar, organizar e que regem os territórios indígenas, questão de grande importância em Estados como o colombiano, que reconheceram o Estado multiétnico e multicultural da sua população.

Dando as comunidades com temporalidades, as formas de organização social e visões do mundo diametralmente opostos do estado e a sociedade nacional, o direito à autodeterminação.

Apresentando o que chamamos nesta dissertação como fricção interétnica na situação de coexistência de diferentes práticas culturais, dentro do mesmo espaço, "entre duas populações dialeticamente unificada através de interesses diametralmente opostos, mas paradoxalmente interdependentes. (CARDOSO OLIVEIRA, 1981, p. 26). Uma vez que são parte de um sistema interétnico que configura tudo sincrético assimétrico das relações interétnicas de grupos sociais com relações de poder.

A governação proposta e a autonomia com que os povos indígenas buscam superar a inclusão de subordinante existente sob a estrutura do estado-nação multiétnica e multicultural, é um exercício de descolonização da autodeterminação baseada em princípios geradores de unidade 
e articulação social, econômica e política para o interior dos povos e toda a sociedade sob as formas de representação e administração de seus territórios.

Enquanto o governo através do Regulamento dos direitos culturais territoriais concedida aos povos indígenas, no âmbito da Constituição política de 1991 multicultural visa criar artefatos de subordinante e integração assimétrica como tecnocráticas esquemas de implementação do direito a governar os territórios indígenas coletivos de acordo com suas tradições e costumes. Então para muitos pesquisador Carlos Duarte (2010) colombiano antropólogo e cientista político francês David Recondo (2008) reconhecimento multicultural que se originou dos componentes das últimas décadas do século XX em muitos países da América Latina, a operado como a estratégia do gato marrom, ou seja, "se queremos que tudo continua como está, é necessário que tudo mude" (Tomasi di Lampedusa 2004). Como para a exigibilidade dos direitos culturais de diferentes como nós pode ser vistos no caso da aldeia da nasa, no município de Toribío na administração e governança de seus territórios coletivos.

Um gato leopardo étnico, que são os direitos reconhecidos aos povos étnicos através de uma legitimidade nacional e internacional, desde sua executividade no altere a ordem predeterminada. O caso do povo da nasa estudado nesta dissertação permite-me afirmar que, embora o exercício dos direitos multiculturais não pode ser interpretado como a plena realização das ações contra a exclusão social, de autonomia e reconhecimento ao contrário historicamente reivindicada por organizações indígenas.

Também não podem ser considerados unilateralmente como um reflexo sintomático da instalação do projeto neoliberal esse status de agência pelos governos das últimas décadas. Porque, como vemos no caso da gestão e a governação dos territórios indígenas coletivos do município de Toribío é uma fricção interétnica na colisão de dois diferentes modelos sociais.

\subsection{Considerações finais}

Ao terminar a elaboração desta dissertação, há vários elementos identificados na administração e governança dos guardas de San Francisco, Toribío e Tacueyó que compõem o município de Toribío, que continuarei a trabalhar a partir das informações adquiridas durante o trabalho de campo e investigações a realizar.

Neste sentido nestas considerações finais sozinhos vou mencionar alguns dos temas que esta dissertação deixa na minha agenda de pesquisa para continuar o trabalho desenvolvido para 
estudar a gestão e a governação dos territórios indígenas coletivas na Colômbia desde a reforma multicultural da constituição de 1991. Um desses elementos vai continuar a trabalhar na é no conceito histórico, presente na memória coletiva do povo da nasa e seu uso político. Uma vez que permitiu-lhe para reinterpretar o processo histórico em que suas ações políticas lhes permitiram defender seu território e a cultura através de suas narrativas.

Assim, transformar o passado em um artefato político que dá legitimidade às suas reivindicações no presente e seus projetos no futuro. A fim de contribuir para a configuração dos quadros interpretativos da administração e gestão pública dos territórios indígenas na Colômbia é necessário aprofundar a análise de políticas públicas e reformas institucionais relacionadas às disposições do multicultural estipulados na constituição de 1991.

Finalmente, considero muito importante para aumentar o trabalho proposto nessa pesquisa da etnografia dos indígenas territórios como entidades territoriais do qual reconhece a propriedade coletiva de uma territorialidade que sustenta a identidade cultural dos povos indígenas e dos conselhos como uma instituição comunitária com reconhecimento e ligação do estado para a administração e gestão pública. Centrando-se sobre a proposta de que as organizações indígenas locais, nacionais e regionais para o estabelecimento completo de entidades territoriais indígenas e a formulação dos indígenas lei regulamentar que a operação. Como minga e o Assembly como uma governança planejamento e comunidade. 


\section{REFERÊNCIAS BIBLIOGRÁFICA}

ANACONA Lenin, Movimiento Indígena del Cauca, Trabajo de grado, Maestría en Desarrollo con Identidad, UAIIN, 2009.

ARBOLEDA LLORENTE, José maría. El indio en la Colonia. Bogotá: Ministerio de Educación Nacional, 1948.

ASSIES, Willem; VAN DEL HAAR Gemma; HOEKEMA, André (Orgs.). El reto de la diversidad. Pueblos indígenas y reforma del Estado en América Latina. Zamora, Méx.: El Colegio de Michoacán 1999.

AGUANDO, Fray Pedro. Recopilación historial. Bogotá: Biblioteca de la Presidencial de Colombia 1956. [1575].

ACOSTA Adrián. "Gobernabilidad y democracia. Perspectivas del debate a veinte años del reporte a la Comisión Trilateral”, en Noesis 13, Gobernabilidad y democracia, 2001.

AGUILERA García Luis "Gobernabilidad y Gobernanza: Cinco Tesis a la Luz del Capitalismo Neoliberal del Siglo XXI", en Gobernabilidad, Comunidad virtual de desarrollo humano e institucional, 2002.

BONILLA, Víctor Daniel. Siervos de Dios y Amos de Indios. Bogotá: Edit. Tercer Mundo, 1980. -Historia política de los Paeces. Cali: Ediciones Colombia Nuestra, 1980.

Que politica buscan los indígenas?, en Indianidad y Descolonización en América Latina: Documentos de la segunda reunion de barbados. BONFIL BATALLA, Guillermo(org),Mexico: Nueva Imagen mexico 1979.

BENAVIDES, Carlos; DUARTE, Carlos. Gobernabilidad política, gobernanza económica y gobiernos indígenas. Límites estructurales e interpretaciones divergentes de los derechos pluriétnicos en el sistema general de participaciones. Bogotá: Revista análisis político n ${ }^{\circ} 68$, eneroabril, 2010: págs. 26-42.

BERNAL VILLA, Segundo. Aspectos de la Cultura Páez. Mitología y cuentos de la parcialidad de Calderas, Tierradentro. Bogotá: Revista Colombiana de Antropología Nº1, 1953.

-Medicina y magia entre los Paeces. Bogotá: Revista Colombiana de Antropología No. 2,1954 . 
---Economía de los Páez. Bogotá: Revista Colombiana de Antropología No. 3, 1954.

--Bases para el estudio de la organización social Páez. Bogotá: Revista Colombiana de Antropología N. 4, 1955.

BENJAMIN, Walter. Iluminations. New york: Benjamín, 1968

BOTERO, Esther Sánchez; JARAMILLO SIERRA, Isabel Cristina. La jurisdicción especial indígena. Bogotá: Procuraduría General de la Nación- Procuraduría Delegada Para Minorías Étnicas, 2001.

CRUZ GONZÁLEZ, David. Los Paeces: o, Genocidio y luchas indígenas en Colombia. Bogotá: La Rueda Suelta, 1978.

CARDOSO DE OLIVEIRA, Roberto. [1964] O Índio e o Mundo dos Brancos. Brasilia: 3 edição, Editora Universidade de Brasilia; São Paulo: Pioneira, 1981.

- A Sociología do Brasil Indígena. Rio de Janeiro: Tempo Brasileiro; Editora UnB, 1978. Identidade, Etnia e Estrutura social. São Paulo: Livraria Pioneira Editora, 1976.

CRIC, Consejo Regional Indígena del Cauca. Diez años de lucha, historia y documentos. Bogotá: Centro de Investigación y Educación Popular, 1981.

CASTILLO CÁRDENAS, Gonzalo. Liberation Theology from Below: The Life and Thought of Manuel Quintín Lame. Maryknoll, Nueva York: Orbis. 1987

CERTEAU, Michel. "La larga marcha india”, en La toma de la palabra y otros escritos políticos. México: Universidad Iberoamericana, 1995).

COLMENARES, Germán. Historia Económica y Social de Colombia, Tomo I 1537-1719. Bogotá: La carreta 1979.

CHANDUVI PASTOR, Gloria Alcia, BONAMOMI, Antonio y ROATTINO, Ezio (Coordinadores). Álvaro Ulcué Nasa Pal Hoy Camino y Semilla. Bogotá: Instituto para Misiones la Consolata, 2011.

DANE, Departamento Administrativo Nacional de Estadística. Censo poblacional general de Colombia, 2005. Bogotá: República de Colombia, 2005.

DNP, Departamento Nacional de Planeación. "Seguimiento y evaluación de la participación de los 
resguardos indígenas en los ingresos corrientes de la nación para el periodo 1998 y 1999”. Bogotá: República de Colombia, 2000.

_-_Los Pueblos indígenas de Colombia en el Umbral del Siglo XXI.” Bogotá: Editorial Víctor Patiño, 2004.

DNP, Dirección de Desarrollo Territorial. "Evaluación de la participación en los ingresos corrientes de la nación asignada los municipios en el periodo 1999-2000 y los resguardos indígenas en el 2000”. Bogotá: Documento para el Desarrollo Territorial №60, 2000.

DUARTE, C. (DES) encuentros en lo público Gobernabilidad y Conflictos Interétnicos en Colombia. Thèse de doctorat en sociologie, Universite Sorbonne Nouvelle - Paris 3, 2015. ESPINOSA ALZATE, Rubén Darío. El gobierno comunitario de los Territorios indígenas del Norte del Cauca. ACIN, CODACOP, CAFOD, 2003.

ESTERMANN, Josef. La filosofía andina. Quito: Abya-Yala, 1998.

FALS BORDA, O. Conocimiento y poder popular: lecciones con campesinos de Nicaragua, México, Colombia. Bogotá: Siglo XXI, 1985.

FRIEDE, Juan. El indio en lucha por la tierra: historia de los resguardos del macizo central colombiano, Bogotá: Instituto Indigenista de Colombia, 1944.

- Los Andaqui, 1538-1947. Historia de la aculturación de una tribu selvática. México:

F.C.E, 1974.

FINDJI, María Teresa; ROJAS, José María. Territorio, Economía y Sociedad Páez. Cali: Universidad del Valle, 1985.

FINDJI, María Teresa. Elementos para el estudio de los resguardos indígenas del Cauca: censo indígena del Cauca 1972. Bogotá: República de Colombia, Departamento Administrativo Nacional de Estadística, 1978.

FRIEDEMANN, Nina; AROCHA, Jaime. Herederos del jaguar y la Anaconda. Bogotá: Carlos Valencia Editores 1982.

GROS, Christian. Colombia Indígena. Identidad cultural y cambio social, CEREC, 1991.

GOMEZ, Herinaldy. Poder étnico y reconocimiento de la diversidad cultural. In: De la Justicia y 
poder indígena. Popayán: editorial universidad del Cauca, 2000.

GOMEZ, Herinaldy; RUIZ, Carlos Ariel. Los Paeces gente territorio: metáfora que perdura. Popayán: Universidad del Cauca, 1997.

GONZÁLEZ;OTERO. La presencia diferenciada del Estado: un desafío a los conceptos de Gobernabilidad y gobernanza.

Dispinible en: http://www.institut gouvernance.org/en/analyse/fche-analyse-237.html, acceso en: mayo 2014.

GOW, David D; RAPPAPORT, Joanne."The indigenous public voice: The multiple idioms of modernity in native Cauca", im: Kay B. Warren \& Jean E. Jackson (eds) Indigenos movements, self-representation and the State in Latin-America, Austin, University of Texas Press, 2002.

Gow, David. “¿Pueden los subalternos planificar? Etnicidad y Desarrollo en Cauca, Colombia”. En: María Lucía Sotomayor (ed.). Modernidad, identidad y desarrollo: Construcción de sociedad y recreación cultural en contextos de modernización. Bogotá: Instituto Colombiano de Antropología, 1998.

"Desde afuera y desde adentro: la planificación indígena como contra-desarrollo". En: Joanne Rappaport (editora). Retornando la mirada: Una investigación colaborativa interétnica sobre el Cauca a la entrada del milenio. Popayán: Universidad del Cauca, 2005.

Replanteando el desarrollo: Modernidad indígena e imaginación moral, Bogotá, Editorial Universidad del Rosario, 2010.

GONZALES, David. Los paeces o genocidio y luchas indigenas en Colombia. Bogota: La rueda suelta 1979.

GONZALEZ PINEROS, Nidia Catherine. "El nuevo movimiento indígena caucano y sus paradigmas de interpretación." Cali: Editorial Bonaventuriana, 2004.

--------"Colombia hacia una democracia participativa: Contribuciòn indìgena 1990 - 2003." Cali: Sello Editorial Javeriano, 2006.

"Movimiento indígena Caucano: historia y política." Bogota: Sello Editorial Universidad Santo Tomas, 2009.

HENMAN, Anthony. Mama Coca. Bogotá: El Ancora Editores y Editorial Oveja Negra, 1978. 
HUYNH-QUAN-SUU, C. Étymologie du terme “gouvernance”. Unión Europea - Documento interno, 2001.

JARAMILLO, Iván; DÍAZ GRANADOS, Luis Adolfo. "La mora accipendi en el derecho del trabajo colombiano". En Colombia Estudios Socio-Jurídicos. Ed: Facultad De Jurisprudencia de La Universidad del Rosario Centro Editorial Rosarista. V.13 fasc.2 pp. 411 - 420, 2011.

JIMENO, Myriam; TRIANA ANTORVEZA, Adolfo. Estado y minorías Étnicas en Colombia. Bogotá: Cuadernos del Jaguar y Funcol, 1985.

JIMENO, Myriam. La vocación critica de la Antropología en Latinoamerica. Antípoda n 1, 2005. Julio Tunubalá, Manuel Trino Morales y Juan Gregorio Palechor, Historia del Consejo Regional Indígena del Cauca (CRIC), Popayán, enero de 1974.

KOOIMAN, Jan. 1993. «Governance and Governability: Using Complexity, Dynamics and Diversity». Modern Governance, comp. by Jan Kooiman. London: Sage: 35-48.LÓPEZ GARCÉS, Claudia Leonor. Los ticuna frente a los procesos de nacionalización en la frontera entre Brasil, Colombia y Perú. Bogotá: Revista Colombiana de Antropología, Volumen 38, enero-diciembre 2002, pp. 77-104.

Ticunas Brasileros, colombianos y peruanos: Etnicidad y nacionalidad en la Región de fronteras del alto Amazonas/Solimões. Brasília: Tese departamento de Ciências Sociais da UnB, 2000.

A questão indígena na Colômbia: movimentos indígenas, políticas indigenistas e conflito armado. In: Reunião de Estudos: Ascensão de Movimentos Indigenistas na América do sul e possíveis reflexos para o Brasil. I reunião de estudos: Ascensão de Movimentos indigenistas na América do Sul e Possíveis reflexos para o Brasil. Brasília: Gabinete de Segurança Institucional, Secretaria de Acompanhamento e Estudos Institucionais, 2004.

LONDOÑO, Julio. La geografía y el hombre de Tierra dentro. Bogotá: Revista Colombiana de Antropología, No. 4, 1955.

LAME CHANTRE, Manuel Quintín. Las luchas del indio que bajó de la montaña al valle de la "civilización". Bogotá: Rosca de Investigación y Acción Social, 1971.

MORENO, Renata. As organizações indígenas e camponesas frente ao conflito armado no norte do Cauca, Colômbia: um estudo de caso. Brasilia: Universidad de Brasilia, tesis de maestría, Centro 
de Investigación y Pos-graduación sobre las Américas, 2007.

MUNICIPIO DE TORIBIO, Alcaldía municipal. Plan de desarrollo Municipal 2012-2015, el futuro lo construimos entre todos. Toribio: Administración Municipal de Toribio, 2012.

MUNICIPIO DE TORIBÍO. Plan de Desarrollo del Municipio de Toribío, Departamento del Cauca, 2008-2011.

MORALES, Trino. "El movimiento indígena en Colombia", in Documentos de la Segunda Reunión de Barbados. Indianidad y descolonización en América Latina. Ciudad do México: Nueva Imagen, 1979.

MORALES, Trino; GROS, Christian. A mí no me manda nadie, historia de vida de trino Morales. Bogotá: ICANH 2010, 319 p

MUELAS HURTADO, Bárbara. "Relación espacio-tiempo en el pensamiento guambiano," en: Proyecciones Lingüísticas, Vol. 1, № 1, Maestría en Lingüística, Universidad del Cauca, Popayán, septiembre, 1995, págs. 31-40, gráfico, figuras.

NACHTIGAL, Horst. Shamanismo entre los indios Paeces. Bogotá: Revista Colombiana de Folklor. № . 1, 1953.

NIEVES OVIEDO, Rocio; ROJAS,Tulio; YULE, Marcos. Estudios Fonológicos de la Lengua Paez (Nasa Yuwe); Descripciones 6; Colciencias - Universidad de los Andes, Bogotá,1991.

OLIVEIRA, João Pacheco. O nosso governo: Os Ticunas e o regime tutelar. São Paulo/ Brasília: Marco Zero/CNPq, 1988.

OTERO, Jesús M. Etnología caucana: estudio sobre los orígenes, vida, costumbres y dialectos de las tribus indígenas del Departamento del Cauca. Popayan: Editorial Universidad del Cauca, 1952. OTERO BAHAMON, Silvia. Los conflictos de autoridad entre los indígenas y el Estado. Algunos apuntes sobre el Norte del Cauca. París: Instituto de investigación y de debate sobre la gobernanza, 2006.

OVIEDO OSPINA, Carlos Andrés. Cabildo indígena e construção do estado-nação. Etnografia do processo organizativo de vitimas da violência em Cauca, Colômbia. Disertación de maestria em antropologia social. Universidade de Brasília, 2014

PACHÓN, Ximena. Los Páez. Introducción a la Colombia Amerindia. Bogotá: Instituto 
Colombiano de Antropología, 1987.

PADILLA, Guillermo. La ley y los pueblos indígenas en Colombia. Journal of Latin American Anthropology 1.2 (1996): 78-97.

PEREIRA, Edmundo. Um povo sábio, um povo aconselhado. Ritual e política entre os Uitotomurui. Brasília : Paralelo 15, 2012.

PEÑARANDA, Daniel Ricardo. La organización como expresión de resistencia, en Nuestra vida ha sido nuestra lucha, Resistencia y Memoria en el Cauca indígena. Bogotá: Centro de Memoria Histórica, 2012.

PERDOMO DIZU, Adonías. "Actores de Autoridad: Una Mirada desde el Pueblo Nasa de Pitayo, en: J. Rappaport, Retornando la mirada: una investigación colaborativa interétnica sobre el Cauca a la entrada del milenio. Popayán, Universidad del Cauca, 2005.

PUELLO-SOCARRÁS, José Francisco. "Revolución sin Guerrillas, ¿Guerrillas sin Revolución? La vigencia del concepto Revolución en las Guerrillas Contemporáneas. El caso del Ejército de Liberación Nacional en Colombia" La Revolución En El Bicentenario. Reflexiones Sobre La Emancipación, Clases Y Grupos Subalternos. Ed. Consejo Latinoamericano De Ciencias Sociales Clacso, v., p.347-368, 2009.

QUIJANO, Aníbal. "Colonialidad del poder, eurocentrismo y América Latina.” En: Lander, Edgardo (org.). La Colonialidad del saber: eurocentrismo y las ciencias Sociales. Buenos Aires: Consejo Latinoamericano de Ciencias Sociales - CLACSO, 2005.

ROLDÁN, Or. Pueblos indígenas y leyes en Colombia. Aproximación crítica al estudio de su pasado y su presente. Bogotá: Gaia/Coama/OIT, 2000.

RAMOS, Alcida Rita. Convivência interétnica no Brasil. Os índios e a nação brasileira. Brasília: UnB, Série Antropologia 221. 1997.

RAPPAPPORT, JOANNE. El país Páez, los pasos en la formación de un territorio. Bogotá: Informe final a la Fundación de Investigaciones Arqueológicas del Banco de la República, 1980.

Mesianismo y las transformaciones de símbolos mesiánicos en Tierradentro. Bogotá: Revista Colombiana de Antropología. Vol. XXIII, 1981.

-Utopías interculturales: intelectuales públicos experimentos con la cultura y pluralismo 
étnico en Colombia. Bogotá: Universidad del Rosario, 2008.

El país Nasa. Los pasos en la formación de un territorio. Bogotá: Informe final a la Fundación de Investigaciones Arqueológicas del Banco de la República, 1980.

------------ Interpretación Indígena de la Historia en los Andes Colombianos. Popayán: Editorial Universidad del Cauca, 2000.

-"Mesianismo y las transformaciones de símbolos mesiánicos en Tierradentro." Bogotá: Revista Colombiana de Antropología, vol. XXIII, 1981.

"Anthropology and Violence in Colombia: An Interview with Hernán Henao." Latin American Anthropology Review 2.2 (1990): 56=60.

"History, Law and Ethnicity in Andean Colombia." Latin American Anthropology Review 2.1 (1990): 13-19.

-DOVER V, Robert. The Construction of Difference by Native Legislators: Assessing the Impact of the 1991 Colombian Constitution. Journal of Latin American Anthropology 1.2 (1996): $22-45$.

RAMOS, Alcida Rita. Los dilemas del pluralismo Brasileiro, Conferencia presentada en la Maestría de Antropología Social. Bogotá: Facultad de Ciencias Humanas, Universidad Nacional de Colombia (Traducción de Renata lleras), Octubre 11 de 2002.

RAMOS PACHO, Abelardo. Memoria de un tejido cultural, social y político del Consejo Regional del Cauca-CRIC. Trayectoria y reflexión, En: Revista Antropos, N. 230, enero-marzo, pp. 90-11, 2011.

REPÚBLICA DE COLOMBIA. 1991. Constitución política de Colombia. Bogotá: Ediciones JR Bernal, 1991.

RIVERA CUSICANQUI, Silvia. Política e ideología en el movimiento campesino colombiano: el caso de la ANUC. Bogotá: Cinep, 1982.

ROJAS, Tulio. "Plan de Vida". En: Margarita Serie, María Suaza y Roberto Pineda (eds.). Palabras para desarmar. Una aproximación crítica al vocabulario del reconocimiento cultural en Colombia. Bogotá: Ministerio de Cultura, Instituto Colombiano de Antropología e Historia. 2002 ROJAS, José María; CASTILLO, Luis Carlos. Poder local y recomposición campesina. Cali: 
Cidse, Universidad del Valle, 1991.

ROJAS CASTILLO, José María. La bipolaridad del poder Local, Caldono en el Cauca Indígena. Cali: Universidad del Valle, 1993.

-----------Ocupación y recuperación de los territorios indígenas en Colombia. Bogotá: Análisis político, Universidad Nacional de Colombia, 2000.

ROSALDO, Renato. Hongot Headhunting: 1883-1974. A Estudy in Society and History. Stanford: University Press, 1980.

ROSAS, Gabriel. En descentralización: como el cangrejo. Enero, 2010. http://razonpublica.com SANCHÉZ, E.; R. Roldán; SANCHEZ, M. Derechos e identidad. Los pueblos indígenas y negros en la Constitución Política de Colombia de 1991. Bogotá: Coama/Disloque Editores, 1993.

SALDÍAS, Carmen. La descentralización, en la tierra del olvido. Julio 2008.

http://razonpublica.com

SAFFORD, F; PALACIOS, M. Colombia: fragmented land, divided society. New York: Oxford University Press, 2002.

SANTANA, Pedro. El desarrollo Regional y los Paros Cívicos en Colombia. Editorial Cinep, Bogotá, 1983.

1998. Los movimientos cívicos: el nuevo fenómeno electoral. Revista Foro No 6, Bogotá.

SENDOYA, Mariano. Caloto ante la Historia. Imprenta Departamental del Valle del Cauca, Cali, 1975.

-Toribio, Puerto Tejada. Popayán: Talleres Editoriales del Departamento, 1975.

SOUZA LIMA, Antonio Carlos. Um Grande Cerco de Paz. Poder tutelar, indianidade e formação do Estado no Brasil. Petrópolis: Vozes, 1995, 335 págs.

TATTAY, Pablo. Construcción de poder propio en el movimiento indígena del cauca, en Nuestra vida ha sido nuestra lucha, Resistencia y Memoria en el Cauca indígena. Bogotá: Centro de Memoria Histórica, 2012.

VALLEJO REAL, Ivette Rossana. Derechos territoriales indígenas, movimientos etno políticos y Estado: un estudio comparativo en la Amazonía de Brasil y Ecuador. Brasilia: Tese de doutorado 
Universidade de Brasília. 2006.

VAN DE SANDT, Joris J. Detrás de la máscara del reconocimiento: la lucha por la autonomía y el manejo comunal de recursos en resguardos indígenas, Colombia. Popayán: editorial de la Universidad del Cauca, 2010.

VIECO, Franky; ECHEVERRI (eds). Territorialidad indígena y ordenamiento en la Amazonia. Letícia: Una/Imani/Programa Coama, 2000.

VELASCO, Juan. Historia del reino de Quito en la America Meriodinal,Tomo 2. Quito: Casa de la cultura Ecuatoriana 1977.

VELÁSQUEZ, F. La participación ciudadana en Bogotá: Mirando el presente, pensando el futuro. Alcaldía Mayor de Bogotá, Instituto Distrital de Cultura y Turismo y Departamento administrativo de acción comunal. Bogotá, 2003.

La descentralización y sus enemigos. Mayo 2009. http://razonpublica.com

VÁZQUEZ BARQUERO, A. "Desarrollo endógeno y globalización". En EURE 26-79. Santiago de Chile, 2000.

YULE YATACUÉ, Marcos; VITONAS PAVI, Carmen. Pees kupx fxi’zenxi: nasa üsa' s txi'pnxi. Toribío: Cabildo Etnoeducativo Proyecto Nasa, Municipio de Toribío 2004.

YULE, Marcos. La metamorfosis de la vida: pensar, mirar y vivir desde el corazón de la tierra.

Toribio: Proyecto Nasa, cabildo de etnoeducación, 2003.

ZAMBRANO, Carlos Vladimir. "Voltear el sucio" Ceremonia de los Páez para tener un gobierno limpio" Diversidad es Riqueza. Santafé de Bogotá: Instituto Colombiano de AntropologíaConsejería Presidencial para los Derechos Humanos, 1992.

ZEMELMAN, H. Pensar teórico y pensar epistémico. Los retos de las Ciencias Sociales Latinoamericanas, conferencia dictada en la Universidad de la Ciudad de México, DF, México, (2001).

ZEMELMAN, H. De la historia a la política: la experiencia de América Latina. Universidad de las naciones unidas en coedición XXI editores, s.a de c.v, 2001. 